\title{
ESTUDO COMPARATIVO, POR MEIO DE ANÁLISE CEFALOMÉTRICA EM NORMA FRONTAL, DOS EFEITOS DENTOESQUELÉTICOS PRODUZIDOS POR TRÊS TIPOS DE EXPANSORES PALATINOS
}

DANILO FURQUIM SIQUEIRA

Dissertação apresentada à Faculdade de Odontologia de Bauru, Universidade de São Paulo, como parte dos requisitos para obtenção do título de Mestre em Odontologia, área de Ortodontia.

BAURU

2000 


\section{ESTUDO COMPARATIVO, POR MEIO DE ANÁLISE CEFALOMÉTRICA EM NORMA FRONTAL, DOS EFEITOS DENTOESQUELÉTICOS PRODUZIDOS POR TRÊS TIPOS DE EXPANSORES PALATINOS}

\section{DANILO FURQUIM SIQUEIRA}

Dissertação apresentada à Faculdade de Odontologia de Bauru, Universidade de São Paulo, como parte dos requisitos para obtenção do título de Mestre em Odontologia, área de Ortodontia.

(Edição Revista)

Orientador: Prof. Dr. Renato Rodrigues de Almeida

BAURU

2000 
Siqueira, Danilo Furquim

Si75e Estudo comparativo, por meio de análise cefalométrica em norma frontal, dos efeitos dentoesqueléticos produzidos por três tipos de expansores palatinos -- Bauru, 2000.

238p.: il.; $30 \mathrm{~cm}$.

Dissertação. (Mestrado) -- Faculdade de Odontologia de Bauru. USP.

Orientador: Prof. Dr. Renato Rodrigues de Almeida.

Autorizo, exclusivamente para fins acadêmicos e científicos, a reprodução total ou parcial desta dissertação, por processos fotocopiadores e/ou meios eletrônicos.

Assinatura do autor:

Data: 


\section{DANILO FURQUIM SIQUEIRA}

15 de junho de 1973

Nascimento

São Paulo-S.P.

1992- 1995

Curso de Odontologia

na Faculdade de Odontologia

de Lins.

1997

Professor assistente da UNIPAR APEC - Associação Paranaense de Ensino e Cultura, na Disciplina de Ortodontia.

1998

Curso de Pós-Graduação em

Ortodontia, ao nível de Mestrado, na Faculdade de Odontologia de Bauru, Universidade de São Paulo.

Associações AMO - Associação Maringaense de Odontologia. 
AGRADECIMENTOS 


\section{Agradecimentos Especiais :}

Agradeço aos meus queridos pais, Vera Lúcia Furquim Siqueira e Nilson Siqueira, exemplos de caráter, honestidade e união. De vocês recebi o dom mais precioso que poderiam me dar : a vida. Não contentes, preencheramna de alegrias, carinho, compreensão e principalmente de muito amor. Abriram as portas do meu futuro, iluminando o meu caminho e dando condições para que eu pudesse continuar nesta longa caminhada profissional. Trabalharam dobrado, sacrificando seus sonhos em favor dos meus, não medindo esforços para que eu obtivesse sucesso em mais uma etapa da minha vida. E não foram apenas pais, mas amigos e companheiros, principalmente nas horas em que meus ideais pareciam distantes e inatingiveis, e o estudo um fardo pesado demais. Simplesmente, OBRIGADO.

A minha eterna gratidão e respeito. 
Agradeço a minha eterna DANI, pelo AMOR, apoio, companheirismo e constante incentivo nestes últimos anos e principalmente pela paciência e compreensão nos momentos em que eu estive ausente durante a elaboração deste trabalho. Obrigado pela demonstração constante de carinho e respeito, mesmo nas horas mais dificeis, durante esta longa caminhada.

Meu amor. 
Ao Prof. Dr. Renato Rodrigues de Almeida, que me iniciou nos estudos desta especialidade, um exemplo de educador. Agradeço pela orientação precisa e pela confiança em mim depositada, que foram fundamentais para a realização desta pesquisa. Além de um grande mestre, brindou-me com sua amizade e sua contagiante alegria de viver.

Meu sinceros agradecimentos. 
Ao meu irmão Ronis Furquim Siqueira, à minha cunhada Andréa Miriam Laurindo e aos meus sobrinhos Emanuella e João Henrique, que foram essenciais para que eu pudesse estar aqui hoje;

Ao meu irmão Rafael Furquim Siqueira e sua namorada Luciana, que mesmo distantes transmitiram palavras de incentivo e de apoio;

À minha avó, Zaira Scattolin, fundamental para a minha formação pessoal e profissional. Obrigado pela constante demonstração de carinho e amor transmitidos pela senhora;

À minha avó Iria Zanco Furquim, que me acolheu em sua casa durante o período de Graduação. Foram os melhores anos da minha vida! Sua alegria e vontade de viver serão sempre inesquecíveis;

À senhora Ana Francisca e ao senhor João Reynaldo, que me receberam como um filho, propiciando-me momentos de descontração e amizade, contribuindo para que este sonho se tornasse realidade;

Aos meus cunhados Rezinha e Rogério pelo companheirismo e pelo incentivo e à minha família Bauruense, Renata (Madrinha), Tia Rosa, Tio Wilsinho e Tia Dalva, com quem pude conviver durante estes anos e aprender a admirá-los. 


\section{Agradeço ainda :}

Aos docentes da disciplina de Ortodontia, Professores Doutores Arnaldo Pinzan, José Fernando Castanha Henriques, Guilherme dos Reis Pereira Janson e Marcos Roberto de Freitas, pela amizade, atenção, paciência e pela transmissão dos conhecimentos necessários para a minha formação $e$ desenvolvimento pessoal e profissional;

Ao Professor Doutor Décio Rodrigues Martins, exemplo de dedicação e amor à arte de ensinar, pelos ensinamentos criteriosos transmitidos no primeiro ano do curso e pelos beneficios que isto me proporcionou;

Ao professor José Roberto Lauris, pela disponibilidade e atenção na orientação da análise estatística dos dados desta pesquisa;

Ao Professor Doutor Luís Fernando Pegoraro, presidente da comissão de Pós-graduação, pela dedicação em prol da formação acadêmica dos pósgraduandos da FOB-USP;

Ao Professor Doutor Aymar Pavarini, Diretor da Faculdade de Odontologia de Bauru-USP;

Aos Professores Doutores Orivaldo Tavano e Ana Lúcia Alvares Capelozza, pela disponibilidade e atenção dispensadas, transmitindo os seus conhecimentos na área de radiologia; 
Aos funcionários da Disciplina de Ortodontia, "Tia" Maria, Verinha, Cristina, Cristiane, pelo carinho, amizade e serviços prestados, permitindo o bom desempenho de nossas atividades;

Ao protético Luiz Sérgio Vieira, pela dedicação e precisão na confecção dos aparelhos utilizados durante todo o curso;

Ao Daniel (Boné), pela sua disponibilidade e seu auxílio na realização das figuras inseridas no trabalho;

Aos funcionários da Biblioteca, pelas constantes orientações, essenciais para a concretização desta pesquisa;

Aos funcionários da Disciplina de Radiologia, Walderez, Celinho e Zezinho, sempre disponíveis em nos auxiliar na obtenção das radiografias utilizadas na amostra, pelo respeito e pela amizade dispensadas;

Aos funcionários da Pós-Graduação, pelos serviços essenciais e pela cordialidade que sempre me dispensaram;

Aos pacientes do curso de Mestrado, indispensáveis para a minha formação profissional;

Aos meus amigos Renata e Fernando, exemplos de uma amizade verdadeira, desde a época da Graduação, demonstrando seu amor, ternura e compreensão, não só nos momentos de alegria, mas também nas horas em que mais precisei de um ombro amigo; 
Aos colegas do Curso de Mestrado, Ana Carla, Ana Cláudia, Daniela, Fausto, Karina Cruz, Karyna Valle pela demonstração de união e amizade durante todo o curso e aos amigos Paulo e Roberto, que não foram simplesmente colegas, mas verdadeiros irmãos. Obrigado pela sinceridade e amizade dispensadas, essenciais para a obtenção do sucesso em mais uma etapa de nossa vida;

Aos "agregados", César, Paulo Conti, Alemão, Veridiana, Mauro, Vanessa e Juliana, pelos momentos de alegria e descontração que vivemos durante estes anos;

Aos alunos do Curso de Doutorado, Alexandre, Liliana, Maria Helena, Márcio e Ricardo, pelo convívio e orientação e ao colega Acácio, pelo companheirismo, principalmente durante a seleção dos pacientes para a amostra;

Aos Professores Doutores Eduardo Dainesi e Márcia Yuri Kawauchi, pelos ensinamentos transmitidos e pela amizade sincera;

Ao meus tios Laurindo Zanco Furquim, Gastão Moura Neto e Rosana Maria Furquim Moura, pelo exemplo de dedicação e trabalho em prol da Ortodontia, acreditando em minha capacidade profissional e transmitindo ensinamentos importantes na minha formação docente, profissional e pessoal;

Aos meus familiares, que em todas as fases da minha vida estiveram presentes, demonstrando o valor da união e do respeito, que foram imprescindiveis para moldar o meu caráter; 
À FAPESP, pela concessão da bolsa de estudo durante o curso de Mestrado, imprescindivel para a realização deste trabalho;

A todos os demais colegas, amigos, funcionários, acadêmicos, pósgraduandos, que convivi durante estes anos, que direta ou indiretamente contribuíram para a concretização deste sonho.

Muito Obrigado. 


\section{SUMÁRIO}

LISTA DE FIGURAS ............................................................ xii

LISTA DE TABELAS ......................................................... xiv

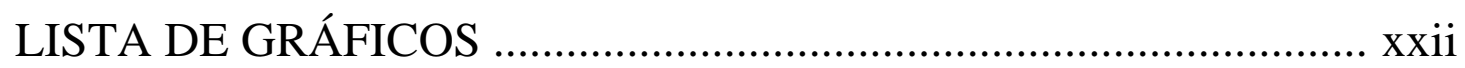

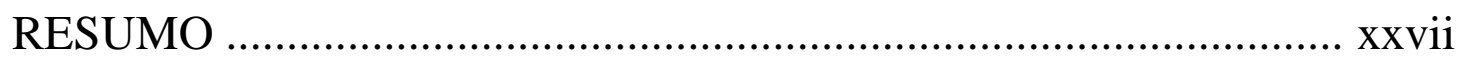

1. INTRODUÇÃ̈O ..................................................................... 1

2. REVISÃO DE LITERATURA ................................................6

3. PROPOSIÇÃO.................................................................... 70

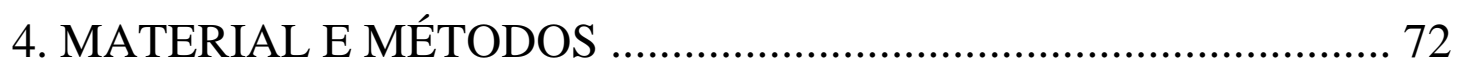

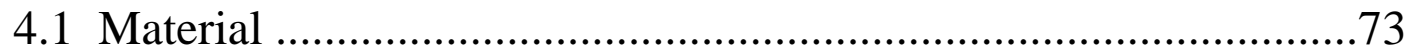

4.2 Métodos .......................................................................... 78

4.2.1 Confecção dos aparelhos ............................................. 78

4.2.2 Instalação e ativação dos aparelhos .................................. 83

4.2.3 Método radiográfico ....................................................... 85

4.2.4 Elaboração do cefalograma ............................................. 87

4.2.5 Análise estatística .................................................... 105

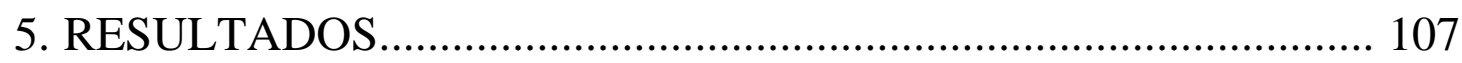

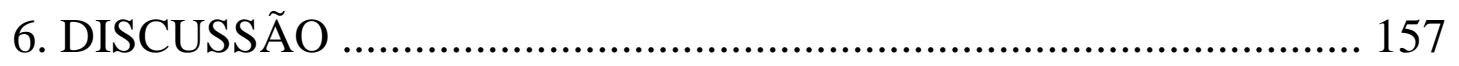

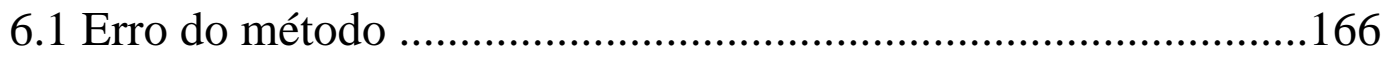

6.2 Distância NC-CN ............................................................ 169

6.3 Distância JL-JR ................................................................ 172

6.4 Molares de ancoragem .................................................... 175

6.5 Molares inferiores ............................................................ 187

6.6 Incisivos centrais superiores .............................................. 190

6.7 Sobremordida e AFAI ...................................................... 196

6.8 Considerações finais ...................................................... 201

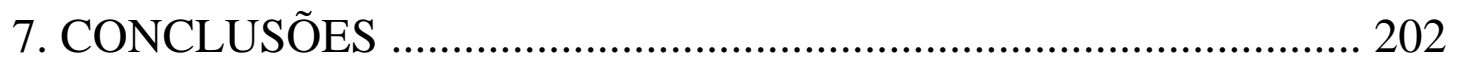

ANEXOS .............................................................................. 205

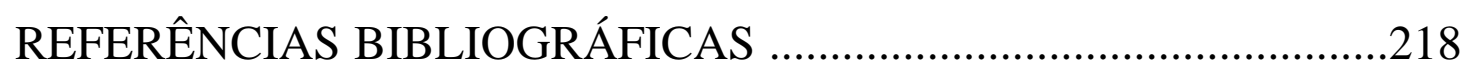

ABSTRACT ....................................................................... 236 


\section{LISTA DE FIGURAS}

FIGURA 4.1 : Confecção do expansor colado - estrutura metálica, adaptação do parafuso e soldagem no $1^{\circ}$ modelo .

FIGURA 4.2 : Confecção do expansor colado - após o polimento dos locais da solda. p. 79

FIGURA 4.3 : Confecção do expansor colado - estrutura metálica (fio $0,9 \mathrm{~mm}$ ), envolvendo as faces vestibulares e linguais dos dentes de ancoragem. .p. 80

FIGURA 4.4 : Confecção do expansor colado - aparelho acrilizado e polido .p. 80

FIGURA 4.5 : Expansor colado - Grupo III p. 81

FIGURA 4.6 : Expansor colado - cobertura de acrílico dos dentes de ancoragem p. 81

FIGURA 4.7 : Expansor tipo Haas modificado - Grupo I .p.82

FIGURA 4.8 : Expansor tipo Hyrax modificado - Grupo II p. 82

FIGURA 4.9 : Desenho Anatômico p. 90 
FIGURA 4.10 : Pontos Cefalométricos ..p.93

FIGURA 4.11 : Pontos Projetados .p.96

FIGURA 4.12 : Linhas e Planos de Referência .p.98

FIGURA 4.13 : Grandezas Lineares .p.101

FIGURA 4.14 : Grandezas Lineares p.102

FIGURA 4.15 : Grandezas Angulares p.104 


\section{LISTA DE TABELAS}

TABELA 4.1 : Distribuição do Grupo I (Haas modificado) segundo a idade e o sexo .p.76

TABELA 4.2 : Distribuição do Grupo II (Hyrax modificado) segundo a idade e o sexo .p.76

TABELA 4.3 : Distribuição do Grupo III (expansor colado) segundo a idade e o sexo .p.77

TABELA 5.1 : Médias (X) e desvios-padrão (D.P.) das medidas cefalométricas analisadas no Grupo I (Haas modificado), nas fases pré-expansão (1), pós-expansão (2) e pós-contenção ..p.110

TABELA 5.2 : Médias (X) e desvios-padrão (D.P.) das medidas cefalométricas analisadas no Grupo II (Hyrax modificado), nas fases pré-expansão (1), pós-expansão (2) e pós-contenção (3) p.111

TABELA 5.3 : Médias (X) e desvios-padrão (D.P.) das medidas cefalométricas analisadas no Grupo III (expansor colado), nas fases pré-expansão (1), pós-expansão (2) e pós-contenção (3) p.112 
TABELA 5.4 : Significância estatística, médias (X) e desvios-padrão (D.P.) das medidas cefalométricas e das diferenças entre as fases pré-expansão (1) e pós-expansão (2), observadas no Grupo I (Haas modificado) p.113

TABELA 5.5 : Significância estatística, médias (X) e desvios-padrão (D.P.) das medidas cefalométricas e das diferenças entre as fases pós-expansão (2) e pós-contenção (3), observadas no Grupo I (Haas modificado) p.114

TABELA 5.6 : Significância estatística, médias (X) e desvios-padrão (D.P.) das medidas cefalométricas e das diferenças entre as fases pré-expansão (1) e pós-contenção (3), observadas no Grupo I (Haas modificado) p.115

TABELA 5.7 : Significância estatística, médias (X) e desvios-padrão (D.P.) das medidas cefalométricas e das diferenças entre as fases pré-expansão (2) e pós-expansão (2), observadas no Grupo II (Hyrax modificado) p.116 
TABELA 5.8 : Significância estatística, médias (X) e desvios-padrão (D.P.) das medidas cefalométricas e das diferenças entre as fases pós-expansão (2) e pós-contenção (3), observadas no Grupo II (Hyrax modificado) .p.117

TABELA 5.9 : Significância estatística, médias (X) e desvios-padrão (D.P.) das medidas cefalométricas e das diferenças entre as fases pré-expansão (1) e pós-contenção (3), observadas no Grupo II (Hyrax modificado) .p.118

TABELA 5.10 : Significância estatística, médias (X) e desvios-padrão (D.P.) das medidas cefalométricas e das diferenças entre as fases pré-expansão (1) e pós-expansão (2), observadas no Grupo III (expansor colado)

TABELA 5.11 : Significância estatística, médias (X) e desvios-padrão (D.P.) das medidas cefalométricas e das diferenças entre as fases pós-expansão (2) e pós-contenção (3), observadas no Grupo III (expansor colado) p. 120 
TABELA 5.12 : Significância estatística, médias (X) e desvios-padrão (D.P.) das medidas cefalométricas e das diferenças entre as fases pré-expansão (1) e pós-contenção (3), observadas no Grupo III (expansor colado).

TABELA 5.13 : Médias (X), desvios-padrão (D.P.) das diferenças das medidas cefalométricas analisadas nas fases pré-expansão (1) e pós-expansão (2), o valor de "F", de "p" e a significância estatística da variância aplicada na comparação dos três grupos

TABELA 5.14 : Médias (X), desvios-padrão (D.P.) das diferenças das medidas cefalométricas analisadas nas fases pós-expansão (2) e pós-contenção (3), o valor de "F", de "p" e a significância estatística da variância aplicada na comparação dos três grupos

TABELA 5.15 : Médias (X), desvios-padrão (D.P.) das diferenças das medidas cefalométricas analisadas nas fases pré-expansão (1) e pós-contenção (3), o valor de "F", de "p" e a significância estatística da variância aplicada na comparação dos três grupos .p. 124 
TABELA 5.16 : Comparações entre os três grupos, com as médias e os valores de "p", realizada com o teste de Tukey, para a variável (CSC3) - (CSC1), que apresentou diferença estatisticamente significante na ANOVA

TABELA 5.17 : Comparações entre os três grupos, com as médias e os valores de "p", realizada com o teste de Tukey, para a variável (CIC2) - (CIC1), que apresentou diferença estatisticamente significante na ANOVA

TABELA 5.18 : Comparações entre os três grupos, com as médias e os valores de "p", realizada com o teste de Tukey, para a variável (CIC3) - (CIC2), que apresentou diferença estatisticamente significante na ANOVA

TABELA 5.19 : Comparações entre os três grupos, com as médias e os valores de "p", realizada com o teste de Tukey, para a variável (CIC3) - (CIC2), que apresentou diferença estatisticamente significante na ANOVA p. 128 
TABELA 5.20 : Comparações entre os três grupos, com as médias e os valores de "p", realizada com o teste de Tukey, para a variável (6A-JR3) - (6A-JR1), que apresentou diferença estatisticamente significante na ANOVA

TABELA 5.21 : Comparações entre os três grupos, com as médias e os valores de "p", realizada com o teste de Tukey, para a variável (6L.Z2) - (6L.Z1), que apresentou diferença estatisticamente significante na ANOVA p. 130

TABELA 5.22 : Comparações entre os três grupos, com as médias e os valores de "p", realizada com o teste de Tukey, para a variável (6L.Z3) - (6L.Z2), que apresentou diferença estatisticamente significante na ANOVA p.131

TABELA 5.23 : Comparações entre os três grupos, com as médias e os valores de "p", realizada com o teste de Tukey, para a variável (AI-IA3) - (AI-IA2), que apresentou diferença estatisticamente significante na ANOVA 
TABELA 5.24 : Comparações entre os três grupos, com as médias e os valores de "p", realizada com o teste de Tukey, para a variável (IM-MI3)-(IM-MI1), que apresentou diferença estatisticamente significante na ANOVA

TABELA 5.25 : Comparações entre os três grupos, com as médias e os valores de "p", realizada com o teste de Tukey, para a variável (A1R.Z2)-(A1R.Z1), que apresentou diferença estatisticamente significante na ANOVA

TABELA 5.26 : Comparações entre os três grupos, com as médias e os valores de "p", realizada com o teste de Tukey, para a variável (A1L.Z2)-(A1L.Z1), que apresentou diferença estatisticamente significante na ANOVA

TABELA 5.27 : Comparações entre os três grupos, com as médias e os valores de "p", realizada com o teste de Tukey, para a variável (A1L.Z3)-(A1L.Z2), que apresentou diferença estatisticamente significante na ANOVA 
TABELA 5.28 : Análise intra-examinador da precisão do método cefalométrico. Apresentação dos erros casuais (Dahlberg), nos três tempos das radiografias p.137

TABELA 5.29 : Análise intra-examinador da precisão do método. Valores iniciais e repetidos após dois meses (médias e desvios-padrão), diferença das médias, valor de "t", de "p" e a significância estatística dos erros sistemáticos .p.138-139

TABELA 5.30 : Análise interexaminadores da precisão do método. Valores (médias e desvios-padrão) obtidos por MAZZIEIRO ${ }^{65}$ e pelo autor, diferenças das médias, valores de "t", de "p" e a significância estatística p. 140

TABELA 5.31: Médias (X), desvios-padrão (D.P.) dos valores iniciais (fase pré-expansão), valor de "p" e a significância estatística da análise de variância aplicada na comparação dos três grupos .p. 141 


\section{LISTA DE GRÁFICOS}

GRÁFICO 5.1 : Valores médios observados para a variável NC-CN p.142

GRÁFICO 5.2 : Valores médios observados para a variável JL-JR p.142

GRÁFICO 5.3 : Valores médios observados para a variável RSR p.143

GRÁFICO 5.4 : Valores médios observados para a variável CSC p.143

GRÁFICO 5.5 : Valores médios observados para a variável CIC p.144

GRÁFICO 5.6 : Valores médios observados para a variável A6-JL .p.144

GRÁFICO 5.7 : Valores médios observados para a variável 6A-JR p.145

GRÁFICO 5.8 : Valores médios observados para a variável 6R.Z 
GRÁFICO 5.9 : Valores médios observados para a variável 6L.Z p. 146

GRÁFICO 5.10 : Valores médios observados para a variável AI-IA p.146

GRÁFICO 5.11 : Valores médios observados para a variável IM-MI p.147

GRÁFICO 5.12 : Valores médios observados para a variável A1R.Z p. 147

GRÁFICO 5.13 : Valores médios observados para a variável A1L.Z p.148

GRÁFICO 5.14 : Valores médios observados para a variável SOBREMORDIDA p.148

GRÁFICO 5.15 : Valores médios observados para a variável AFAI ..p.149

GRÁFICO 5.16 : Variações percentuais observadas para a medida NC-CN, nos três grupos estudados p. 150

GRÁFICO 5.17 : Variações percentuais observadas para a medida JL-JR, nos três grupos estudados 
GRÁFICO 5.18 : Variações percentuais observadas para a medida RSR, nos três grupos estudados

GRÁFICO 5.19 : Variações percentuais observadas para a medida CSC, nos três grupos estudados

GRÁFICO 5.20 : Variações percentuais observadas para a medida CIC, nos três grupos estudados p. 152

GRÁFICO 5.21 : Variações percentuais observadas para a medida A6-JL, nos três grupos estudados

GRÁFICO 5.22 : Variações percentuais observadas para a medida 6A-JR, nos três grupos estudados

GRÁFICO 5.23 : Variações percentuais observadas para a medida 6R.Z, nos três grupos estudados

GRÁFICO 5.24 : Variações percentuais observadas para a medida 6L.Z, nos três grupos estudados p. 154

GRÁFICO 5.25 : Variações percentuais observadas para a medida AI-IA, nos três grupos estudados p. 155

GRÁFICO 5.26 : Variações percentuais observadas para a medida A1R.Z, nos três grupos estudados p. 155 
GRÁFICO 5.27 : Variações percentuais observadas para a medida A1L.Z, nos três grupos estudados p. 156

GRÁFICO 6.1 : Valores médios observados para a variável $\mathrm{NC}-\mathrm{CN}$ p. 170

GRÁFICO 6.2 : Valores médios observados para a variável JL-JR p.173

GRÁFICO 6.3 : Valores médios observados para a variável RSR p.176

GRÁFICO 6.4 : Valores médios observados para a variável CSC p.176

GRÁFICO 6.5 : Valores médios observados para a variável A6-JL p. 180

GRÁFICO 6.6 : Valores médios observados para a variável 6A-JR p. 180

GRÁFICO 6.7 : Valores médios observados para a variável 6R.Z p.183

GRÁFICO 6.8 : Valores médios observados para a variável 6L.Z 
GRÁFICO 6.9 : Valores médios observados para a variável CIC

GRÁFICO 6.10 : Valores médios observados para a variável AI-IA p.191

GRÁFICO 6.11 : Valores médios observados para a variável IM-MI .p.191

GRÁFICO 6.12 : Valores médios observados para a variável A1R.Z p.194

GRÁFICO 6.13 : Valores médios observados para a variável A1L.Z p.195

GRÁFICO 6.14 : Valores médios observados para a variável SOBREMORDIDA p.197

GRÁFICO 6.15 : Valores médios observados para a variável AFAI .p.199 
RESUMO 


\section{RESUMO}

Realizou-se um estudo cefalométrico comparativo dos efeitos de três tipos de expansores palatinos, utilizados para a expansão rápida da maxila $(E R M)$, com o objetivo de observar, por meio de radiografias póstero-anteriores, as alterações dentoesqueléticas decorrentes da expansão e as possíveis diferenças entre os aparelhos. A amostra foi constituída por 63 pacientes (23 do sexo masculino e 40 do sexo feminino) divididos em três grupos : - Grupo I, composto por 20 pacientes, sendo 12 do sexo feminino e 8 do masculino, que utilizaram o expansor dentomucossuportado (Haas modificado), com idade média de 13 anos e 5 meses na época da instalação do aparelho; - Grupo II, composto por 21 pacientes, sendo 14 do sexo feminino e 7 do masculino, que utilizaram o expansor dentossuportado (Hyrax modificado), com idade média de 12 anos e 10 meses na época da instalação do aparelho e - Grupo III, composto por 22 pacientes, sendo 14 do sexo feminino e 8 do masculino, que utilizaram o expansor dentossuportado, com cobertura de acrílico, colado aos dentes superiores, com idade média de 12 anos e 5 meses na época da instalação do aparelho. Todos estes pacientes foram radiografados nas fases pré-expansão, imediatamente após a expansão e após os três meses de contenção ativa com o próprio aparelho, totalizando assim, 189 telerradiografias em norma frontal para a realização deste estudo. Baseando-se na metodologia empregada e nos resultados obtidos, constatou-se que : - os três tipos de aparelhos provocaram respostas ortopédicas semelhantes, como o aumento da porção inferior da cavidade nasal e da largura maxilar, que se mantiveram estáveis durante a contenção; - os primeiros molares superiores (dentes de ancoragem) demonstraram comportamentos semelhantes; - as distâncias intermolares inferiores aumentaram nos três grupos, porém com diferenças significativas 
entre o Grupo III, que apresentou pequenas alterações e os demais grupos; - os incisivos centrais superiores demonstraram comportamentos semelhantes nos três grupos, durante o período de expansão e contenção, caracterizados pelos movimentos de inclinação e pela divergência apical e convergência das coroas; com a análise das variáveis SOBREMORDIDA e AFAI (altura facial ânteroinferior), concluiu-se que os três tipos de aparelhos provocaram alterações verticais semelhantes, em decorrência da ERM. 
1. INTRODUÇÃO 


\section{INTRODUÇÃO}

As más oclusões, caracterizadas pelo desequilíbrio do sistema estomatognático, ou seja, a desarmonia entre as estruturas esqueléticas, dentárias e neuromusculares, apresentam uma grande prevalência na população e podem se manifestar precocemente. Estas alterações influenciam negativamente não só a estética do paciente, mas também algumas funções essenciais, como a respiração, a mastigação, a deglutição e a fonação. A Ortodontia e a Ortopedia Facial, mecânica ou funcional, visam o restabelecimento de uma oclusão satisfatória e conseqüentemente, a obtenção de condições mais favoráveis para o desenvolvimento normal do indivíduo.

As terapias ortodônticas e ortopédicas apresentam certas limitações e pouca capacidade terapêutica na correção das alterações verticais, porém, nas discrepâncias dentofaciais ântero-posteriores e transversais, desde que se faça uma intervenção precoce, o prognóstico torna-se muito favorável, uma vez que existem mecanismos e dispositivos capazes de induzir alterações que conduzem à normalidade. A atresia maxilar, um exemplo de má oclusão transversal, geralmente é corrigida com a ortopedia mecânica, ou seja, com aparelhos para a expansão da maxila, que liberam forças sobre os dentes de ancoragem e sobre a maxila, promovendo alterações dentoalveolares e esqueléticas, normalizando as dimensões transversais do arco superior. Existem muitos mecanismos ilustrados na literatura para esta finalidade $5,15,20,29,31,35,42,53,64,66,67,70,72,83,88,102$ e, apesar da grande aceitação atual do procedimento de expansão rápida da maxila (ERM), este passou por períodos de muita controvérsia. 
Logo após o seu advento, descrito por ANGELL ${ }^{8}$, em 1860, a expansão da maxila gerou um grande interesse pelos médicos Rinologistas, devido à capacidade em aumentar transversalmente a cavidade nasal (largura nasal) e conseqüentemente, melhorar a respiração nasal. Porém, este procedimento recebeu muitas críticas, intimidando os ortodontistas americanos, principalmente por influência das idéias de Angle, que se baseavam no conceito funcional de crescimento, no qual acreditava-se que a expansão dentária promovida pela ortodontia conservadora, estimularia o crescimento ósseo intersticial, não necessitando dos efeitos considerados agressivos da ERM. Por outro lado, os europeus continuavam a utilizar esta técnica e pesquisadores como DERICHSWEILER ${ }^{33}$ e KORKHAUS ${ }^{56}$, demonstrando resultados positivos em suas pesquisas, incentivaram o Departamento de Ortodontia da Universidade de Illinois a trabalhar experimentalmente com o expansor ortopédico da maxila. $\mathrm{O}$ reconhecimento da técnica de $E R M$ nos Estados Unidos, se deu principalmente devido aos estudos realizados por $\mathrm{HAAS}^{42}$, onde interpretou as alterações decorrentes deste procedimento com condutas voltadas para a prática clínica, muito utilizadas até os dias atuais.

A partir deste relato ${ }^{42}$, inúmeros estudos histológicos, cefalométricos e em modelos de gesso foram realizados para a verificação das alterações dentoesqueléticas decorrentes da $E R M^{1-4,9,14,19,21,24-28,32,35,37,40,42,43,46,48-51,53,55-58,61,65-}$ 74,76-79,81-83,86,88-93,97-109,111-114. A maior parte dos estudos cefalométricos avaliaram as alterações verticais e sagitais das bases ósseas com a utilização das telerradiografias em norma lateral, devido a facilidade de interpretação deste tipo de radiografia. Porém, para a avaliação das alterações reais da $E R M$ sobre o complexo craniofacial, preconiza-se a análise das radiografias póstero-anteriores (telerradiografia em norma frontal). Apesar de poucos relatos na literatura, este 
método apresenta-se muito eficiente na avaliação das alterações transversais dentárias e das bases ósseas, decorrentes do crescimento e desenvolvimento craniofacial e da terapia expansionista.

Outro ponto bastante controverso na literatura consiste no tipo de ancoragem utilizada pelos expansores palatinos. Não existe um consenso quanto ao tipo de apoio que este aparelho deve apresentar, para causar maiores efeitos ortopédicos e menor desconforto para os pacientes. Alguns autores ${ }^{19,34,42-}$ 46,82,90,111, preconizavam a utilização do expansor dentomucossuportado, para a obtenção de uma ancoragem máxima e de uma maior rigidez do aparelho, favorecendo assim a transferência das forças de ativação às bases ósseas e conseqüentemente permitindo maiores resultados ortopédicos e mais estabilidade na expansão. Porém, a base de acrílico que recobre o palato causa dificuldades de higienização, podendo levar ao aparecimento de lesões no tecido mole, em consequiência da compressão excessiva sobre este. $\mathrm{O}$ aparelho dentossuportado, descrito por BIEDERMAN ${ }^{15}$, apoiado simplesmente nos dentes com o auxílio de bandas, pode ser considerado um aparelho mais higiênico, devido a ausência da resina apoiada no palato. Outros autores $^{5,9,35,53,59,67,69,70,73,83,101,102,105}$ recomendavam o expansor com cobertura de acrílico, colado aos dentes superiores (dentossuportado), devido à facilidade de confecção, instalação e principalmente devido ao maior controle vertical durante a ERM. Porém, este também apresenta algumas desvantagens observadas clinicamente, relacionadas à alimentação, à higienização e ao procedimento de remoção $5,53,66,67,73$. 
Baseados na falta de dados comparativos confiáveis, propusemo-nos a realizar este trabalho, com o objetivo de avaliar as alterações dentoesqueléticas decorrentes da expansão rápida da maxila, utilizando três tipos de expansores palatinos, com ancoragens diferentes, ou seja, o expansor tipo Haas modificado (dentomucossuportado), o expansor tipo Hyrax modificado (dentossuportado) e o expansor com cobertura de acrílico, colado aos dentes superiores (dentossuportado) e as possíveis diferenças entre eles, imediatamente após a expansão e durante o período de contenção. Propusemo-nos ainda, avaliar as principais vantagens e desvantagens dos aparelhos utilizados no estudo e verificar a possível efetividade do expansor colado no controle vertical, durante a $E R M$. 
2. REVISÃO DE LITERATURA 


\section{REVISÃO DE LITERATURA}

Os estudos concernentes à ERM iniciaram-se a partir da metade do século XIX. ANGELL ${ }^{8}$, em 1860, publicou um método de tratamento objetivo para os casos de falta de espaço generalizada no arco superior e atresia maxilar, na tentativa de evitar as extrações dentárias. O trabalho descrevia o tratamento de um paciente do sexo feminino de 14 anos e 5 meses de idade, com o canino superior esquerdo em vestibuloversão e contato entre o incisivo lateral e o $1^{\circ}$ pré-molar. Este consistiu na extração do $1^{\circ}$ molar superior permanente do lado esquerdo (problemas endodônticos) e a instalação de um aparelho fixado nos dentes superiores, com um parafuso posicionado transversalmente à abóbada palatina, que promoveu a separação da sutura palatina mediana da maxila, comprovada clinicamente pelo diastema entre os incisivos centrais superiores.

A importância da intervenção precoce nos casos de atresia maxilar foi observada por BARNES ${ }^{12}$, em 1956. Este preconizou a expansão na fase da dentadura decídua, para evitar más oclusões severas na fase da dentadura permanente. Ilustrou com as fotografias dos modelos pré-tratamento e póscontenção e fotografias extra e intrabucais de seis pacientes, comprovando a estabilidade dos resultados obtidos com a intervenção precoce.

$\mathrm{KREBS}^{57}$, em 1959, questionou os métodos para a avaliação das alterações decorrentes da $E R M$ utilizados em alguns estudos, devido à dificuldade de localização de pontos de referência fixos para a realização de comparações pré e pós-expansão confiáveis. Para solucionar tal problema, lançou mão de implantes metálicos, preconizados por BJÖRK ${ }^{18}$, colocados na maxila (lingual dos caninos) e no processo zigomático, de ambos os lados, o que 
facilitou a avaliação exata dos efeitos da expansão da maxila. Estas alterações foram analisadas em nove pacientes, com o auxílio de modelos de gesso (distância intercaninos e intermolares) radiografias oclusais e telerradiografias em norma lateral e frontal (distância entre os implantes e o aumento da cavidade nasal). Ainda neste artigo, relatou o caso clínico de um paciente de 11 anos de idade, com mordida cruzada posterior bilateral, onde se avaliaram as variáveis descritas anteriormente. O aumento na largura do arco dentário (distâncias intercaninos e intermolares) durante a fase ativa, apresentou-se duas vezes maior do que o aumento na base maxilar (distância entre os implantes no arco zigomático), enquanto o aumento do arco alveolar (distância entre os implantes na lingual dos caninos) permaneceu com valores medianos a estes dois. Observou também aumentos significantes na largura da cavidade nasal, porém menores do que os aumentos da base maxilar. As distâncias intercaninos e intermolares mantiveram-se estáveis, em decorrência do uso de contenção (8 meses), porém as larguras do arco alveolar e da base maxilar recidivaram durante este período de contenção.

Enfatizando a utilização do procedimento de $E R M$ nos casos de atresia maxilar severa, KORKHAUS ${ }^{56}$, em 1960 relatou vários casos clínicos, ilustrando as alterações, como o aumento considerável da largura maxilar e da cavidade nasal, com os modelos de gesso e com as telerradiografias em norma frontal pré-tratamento, pós-tratamento e pós-contenção. O autor ainda alertou sobre a possibilidade de aumento na capacidade nasal (respiratória) nos pacientes respiradores bucais, conseguida com a ERM.

Pesquisando os efeitos da ERM, HAAS ${ }^{42}$, em 1961, realizou um experimento com oito suínos Duroc-Poland China (seis do grupo experimental 
e dois do controle). Instalou-se um aparelho expansor, com ativação por 10 dias, totalizando 12 a $15 \mathrm{~mm}$ de expansão. Injetou-se alizarina, como corante vital dos ossos, após o período de ativação, em intervalos de 4, 14 e 30 dias. Em seguida, partes da maxila foram preparadas e analisadas. Encorajado com os resultados do experimento em animais, que revelavam a eficácia deste procedimento em casos com severa atresia maxilar, o autor analisou 10 pacientes (5 do sexo masculino e 5 do sexo feminino) com este tipo de má oclusão, tratados com a ERM. Realizou-se as observações nas telerradiografias em norma frontal e lateral, nas radiografias oclusais, nos modelos de gesso, nas fotografias e nos comentários dos pacientes sobre a sintomatologia provocada pela expansão. HAAS $^{42}$ ainda descreveu a confecção e a manipulação do aparelho utilizado.

Após a análise dos resultados, observou :

- pequena pressão após a ativação do parafuso, que desaparecia rapidamente ;

- em alguns casos, injúrias no tecido mole do palato, abaixo da porção de acrílico;

- as telerradiografias em norma frontal mostraram as alterações mais interessantes;

- alterações nas dimensões internas da cavidade nasal (aumento do espaço internasal), na distância intermolares e interincisivos superiores;

- aumento na distância intermolares inferiores (0,5 a $2 \mathrm{~mm})$;

- no sentido vertical, a abertura da sutura palatina mediana se dava de forma triangular, com o ápice na cavidade nasal;

- diastema entre os incisivos centrais superiores após a ativação do parafuso, com divergência das raízes e convergência das coroas, que se fechava naturalmente após 4 ou 6 meses, obtendo as inclinações axiais normais, devido à ação das fibras transeptais; 
- na análise das telerradiografias em norma lateral, observou-se que o ponto A se movimentou para frente em todos os casos e também para baixo em cinco casos (50\%), causando uma rotação horária da mandíbula. Como conseqüência, ocorreu um aumento nos ângulos de convexidade facial, do plano mandibular, SNA e na altura facial ântero-inferior (AFAI);

- este pequeno deslocamento da maxila para frente pode ser favorável para a correção da má oclusão de Classe III e pseudo Classe III;

- assim como nos estudos em porcos, os dentes inferiores verticalizaram após a $E R M$. Em todos os casos houve um aumento na distância intermolares e em quatro (40 \%), na distância intercaninos, sem nenhum tipo de mecânica.

Utilizando implantes metálicos posicionados no processo zigomático da maxila e na porção lingual de caninos e molares superiores (palato duro), KREBS $^{58}$, em 1964, analisou durante um período de sete anos, 23 pacientes ( 12 do sexo masculino e 11 do sexo feminino), com idades de 8 a 19 anos no início do tratamento, mordida cruzada posterior bilateral e tratados inicialmente com o procedimento de ERM. Este estudo teve o objetivo de avaliar a estabilidade e os efeitos da abertura da sutura palatina mediana sobre a maxila e a porção superior da face. A análise foi realizada com telerradiografias em norma frontal e lateral, modelos de gesso e fotografias da face. $\mathrm{O}$ autor dividiu didaticamente a maxila em seis regiões para serem analisadas separadamente e para a exemplificação das alterações, relatou um caso clínico. Como resultados destacaram-se:

- os efeitos da ERM apresentavam-se dependentes do sexo e da idade, sendo maiores durante a fase de crescimento puberal (mais precoces nos pacientes do sexo feminino); 
- maior aumento na largura do arco dentário do que da base maxilar, principalmente após a puberdade (maior resistência óssea);

- estabilidade nos aumentos da base maxilar e da cavidade nasal, apesar de uma pequena recidiva observada após um ano de observação. Nos anos subseqüentes, ocorreu um aumento constante destas medidas devido ao crescimento e desenvolvimento craniofacial;

- apesar do grande aumento na largura do arco dentário superior após a expansão, este não permaneceu estável na maioria dos casos, em uma avaliação após 4-5 anos.

Neste mesmo ano, com o objetivo de avaliar os efeitos da $E R M$ sobre os dentes e sobre as estruturas faciais adjacentes, STARNBACH; CLEALL ${ }^{103}$, submeteram quatro Macacus rhesus (um para o grupo controle e três para o grupo experimental) à expansão da sutura palatina mediana com expansores fixos. Após o exame microscópico, concluíram que a movimentação dentária, decorrente da expansão foi predominantemente de corpo e que concomitantemente à expansão da sutura palatina mediana ocorreram alterações nas estruturas faciais circunvizinhas (suturas frontonasal, zigomaticomaxilar e zigomaticotemporal), caracterizadas pelo aumento das atividades celulares.

CLEALL et $\mathrm{al}^{28}$, em 1965, estudaram os efeitos da ERM, principalmente as alterações histológicas na região da sutura palatina mediana, em uma amostra de seis Macacus rhesus fêmeas, com idade variando entre 30 e 40 meses (comparável a 7-9 anos nos humanos), sendo 4 do grupo experimental (aparelho expansor fixo) e 2 do grupo controle. Além do estudo microscópico, obtiveram modelos de gesso e telerradiografias em norma frontal e lateral para complementar o estudo. O primeiro animal do grupo experimental foi 
sacrificado após duas semanas de ativação (4 mm de expansão) do aparelho expansor. Nos outros três animais, realizou-se uma ativação de $2 \mathrm{~mm}$ por mês, durante três meses, totalizando $6 \mathrm{~mm}$ de expansão. Estes animais, assim como os do grupo controle foram sacrificados em tempos distintos, para a observação das alterações e da estabilidade da ERM. Após o sacrifício, a maxila foi removida, radiografada (radiografia oclusal) e preparada para ser analisada microscopicamente. Como resultados, destacaram : - a sutura palatina mediana se rompe em resposta às forças intensas de expansão; - o aumento na largura maxilar, principalmente devido a esta abertura da sutura; - a regeneração rápida e completa (ossificação) do defeito ósseo resultante (abertura da sutura); - a estabilidade das alterações decorrentes da expansão, após o período de contenção.

Objetivando analisar quantitativamente as forças produzidas durante as fases de expansão e de contenção ativa no procedimento de $E R M$, além do tempo necessário do uso desta contenção, ZIMRING; ISAACSON ${ }^{114}$, em 1965, obtiveram uma amostra de quatro pacientes (três do sexo masculino e um do sexo feminino), com idades variando de 11 anos e seis meses a 15 anos e seis meses, com mordidas cruzadas posteriores bilaterais e atresia do arco superior. Estes pacientes foram submetidos à $E R M$, utilizando-se um expansor fixo no arco superior, com um mecanismo para a verificação da força exercida pelo aparelho (dinamômetro). O protocolo de ativação variou entre os pacientes, devido ao acúmulo excessivo das forças residuais. Para os mais jovens, preconizaram duas ativações diárias nos primeiros quatro ou cinco dias e posteriormente apenas uma ativação diária até o final do tratamento. Nos pacientes com idades mais avançadas, devido ao aumento na resistência óssea, indicaram duas ativações diárias apenas nos primeiros dois dias, seguindo-se 
com ativações únicas nos dias subseqüentes. O próprio aparelho foi mantido como contenção, até que as forças residuais fossem totalmente liberadas, sem a instalação de qualquer outro tipo de dispositivo. Confeccionaram-se modelos de gesso imediatamente depois da remoção do expansor, 10 e 30 dias após. Os principais resultados foram analisados em três fases distintas : 1) Fase de Expansão : - a força máxima ocorreu após a ativação e se dissipou rapidamente; - no início do tratamento, as forças produzidas pelas ativações foram dissipadas em no máximo 12 horas; - houve um acúmulo das forças residuais após os dois primeiros dias de tratamento, causado pela dificuldade de dissipação destas forças entre as ativações; - relação entre a idade e o tempo para a dissipação das forças, ou seja, os pacientes mais novos necessitavam de menos tempo para liberação das forças. Isto se explica pela maior resistência óssea em decorrência do aumento da idade e do processo maturacional; - observou-se um diastema entre os incisivos centrais superiores entre a $9^{\mathrm{a}}$ e a $12^{\mathrm{a}}$ ativações; - um aumento considerável na distância intermolares e interpré-molares; - os pacientes relataram uma suave pressão nos dentes, abaixo dos olhos e na área nasal logo após as ativações. 2) Fase de Contenção : observaram forças residuais nos quatro pacientes ao final da fase ativa, porém estas se dissiparam em aproximadamente seis semanas, principalmente na primeira semana. 3) Fase Pós-contenção : as comparações feitas entre as medidas obtidas antes e imediatamente após a remoção do aparelho não demostraram qualquer recidiva; - com os valores obtidos nos modelos de gesso, após 10 e 30 dias do final do tratamento, pôde-se observar uma recidiva na distância intermolares e interprémolares.

HAAS $^{43}$, em 1965, alertou para o tratamento de casos desafiadores na Ortodontia com a ERM. Entre estes estão os casos de Classe III não cirúrgico, 
atresia/deficiência maxilar real ou relativa, estenose nasal com respiração bucal característica, pacientes adultos com fenda palatina e casos com mordida cruzada posterior uni ou bilateral severas. Relatou que este procedimento permite posicionar harmoniosamente os dentes superiores e inferiores e que para obter todos os benefícios desta técnica, deve-se realizar a sobrecorreção do segmento posterior. Com a descrição de três casos clínicos e o auxílio de modelos, de fotografias e dos traçados cefalométricos chegou às seguintes conclusões:

- a abertura da sutura palatina mediana se apresentava de forma triangular, com a base voltada para a cavidade bucal;

- com esta abertura, observou-se um diastema característico entre os incisivos centrais superiores, que se fechou rapidamente, devido à ação das fibras transeptais. Também existiu uma maior sensibilidade nestes dentes;

- aumento na capacidade nasal interna, facilitando a respiração;

- movimento da maxila para baixo e para frente;

- abertura da mordida e aumento no ângulo do plano mandibular.

Analisando 5 Macacus rhesus, sendo 4 do grupo experimental e 1 do grupo controle, STARNBACH et $\mathrm{al}^{104}$, em 1966, questionaram o tipo de movimentação dos dentes de ancoragem (inclinação ou de corpo) e as alterações nas estruturas adjacentes à maxila, decorrentes da ERM. Os animais do grupo experimental foram sacrificados em tempos distintos, para posterior comparação das alterações histológicas com o animal controle. As evidências demonstraram uma maior movimentação de corpo dos dentes analisados e um envolvimento das estruturas faciais adjacentes, caracterizada pela maior atividade celular nas áreas das suturas frontonasal, zigomaticomaxilar e zigomaticotemporal. 
Questionando o aparelho para ERM descrito por $\mathrm{HAAS}^{42}$, considerando que o acrílico que cobria o palato poderia causar irritações ao tecido mole, devido à impacção de alimentos, BIEDERMAN ${ }^{15}$, em 1968, descreveu todos os procedimentos clínicos e laboratoriais para a confecção de um aparelho mais higiênico. Este é dentossuportado, ou seja, apoiado apenas nos primeiros molares e nos primeiros pré-molares superiores, por meio de bandas.

$\operatorname{MOSS}^{71}$, em 1968, citou que a maioria das falhas decorrentes da ERM (rápidas recidivas) ocorrem devido aos erros no diagnóstico e nos tipos de aparelho. Além disto, relatou as indicações deste procedimento, exemplificando com dois casos clínicos. A primeira, seria em pacientes fissurados, nos quais os efeitos da expansão atuariam no melhor relacionamento maxilomandibular, na melhora do perfil facial, da mastigação, da respiração e principalmente uma melhora psicológica, com aumento da auto-estima. Nos casos de Classe III com deficiência maxilar, a ERM também deve ser utilizada, contribuindo para a obtenção de uma harmonia entre os arcos dentários e uma melhora no perfil facial. O autor ainda realçou a importância da sobrecorreção do segmento posterior, em decorrência da recidiva pós-contenção.

Neste mesmo ano, dando continuidade ao artigo anterior, $\operatorname{MOSS}^{72}$ relatou mais duas indicações para a ERM : Classe I, com mordida cruzada bilateral ou com mordida cruzada unilateral severa e casos de Classe II, $1^{\text {a }}$ divisão com atresia maxilar e estenose nasal, sendo demonstradas em dois casos clínicos. O aparelho utilizado era composto por um parafuso expansor, "splints" de prata envolvendo os dentes de ancoragem e uma base de resina acrílica (dentomucossuportado). Acreditava-se que com a utilização destes "splints" no lugar das bandas, a abertura da sutura palatina mediana seria mais paralela e que 
os dentes de ancoragem apresentariam menor inclinação para a vestibular e conseqüentemente menor recidiva. Pôde-se observar também, a abertura de um diastema entre os incisivos centrais superiores, que se fechou rapidamente devido à ação das fibras transeptais e a um aumento considerável no volume da cavidade nasal. Citou ainda que a $E R M$ deve ser realizada, preferencialmente entre 10 e 15 anos.

Investigando as alterações oriundas da abertura da sutura palatina mediana, DAVIS; KRONMAN ${ }^{32}$, em 1969, analisaram os modelos de gesso e as telerradiografias em norma frontal e lateral, pré-expansão e pós-contenção (de 3 a 6 meses) de 26 pacientes submetidos à ERM. Como resultados, concluíram que:

- ocorreu um movimento para frente do ponto A, com exceção de 4 casos que utilizaram ancoragem extrabucal ao final da expansão;

- o ângulo SN-PP aumentou na metade dos casos, em decorrência do abaixamento do ponto A;

- o ângulo do plano mandibular apresentou grande variação nos resultados. Na maioria dos casos, este aumentou e resultou em uma tendência de abertura na mordida. Porém, houve também diminuição e constância neste ângulo;

- o aumento da distância intermolares superiores (média de 6,7 mm) foi em maior proporção do que o aumento da distância intercaninos (média de $3,62 \mathrm{~mm})$;

- no arco inferior também houve um aumento nas distâncias intermolares (média de 0,55 $\mathrm{mm}$ ) e intercaninos $(0,57 \mathrm{~mm})$, sem qualquer tipo de mecânica. 
As alterações da maxila decorrentes da $E R M$ foram estudadas por HALPERN $^{47}$, em 1970, com a utilização de telerradiografias em norma frontal e lateral, radiografias oclusais e mensurações realizadas diretamente no paciente. Com uma amostra de 32 casos tratados, observou-se uma grande correlação entre a quantidade de ativações mecânicas e os efeitos na maxila. Também observou alterações no plano mandibular, nos primeiros molares superiores, nas medidas ântero-posteriores das bases apicais e nas distâncias intermolares e intercaninos. Este estudo ainda alertou para a grande variabilidade individual, ou seja, mesmo em indivíduos com más oclusões semelhantes, as respostas foram variadas.

Após uma revisão dos meios utilizados na investigação das alterações da ERM e da conclusão de que estes apresentavam certas limitações, $\operatorname{HEFLIN}^{49}$, em 1970, analisou os efeitos da expansão sobre os ossos da face com um método tridimensional. A amostra consistiu de telerradiografias em norma lateral, pré e pós-expansão e após um ano do início do estudo de 54 pacientes, divididos em três grupos : 1) grupo com má oclusão tratada, 2) grupo com má oclusão não tratada e 3) grupo com oclusão normal. Estes foram pareados de acordo com as variáveis : gênero, idade (óssea e cronológica), raça, má oclusão, forma facial, tipo e duração do tratamento, possibilitando assim a avaliação dos efeitos da ERM como uma variável independente. Como resultados do grupo tratado, encontrou que :

- a ERM não afetou significantemente a base do crânio;

- não ocorreu nenhuma alteração ântero-posterior significante nas estruturas da face média; 
- a mandíbula apresentou um movimento de rotação para baixo e para trás significante, durante a expansão, com o eixo de rotação localizado no gônio;

- os primeiros molares superiores apresentaram um deslocamento inferior temporário, sem alterações significantes no sentido ântero-posterior;

- a dimensão vertical apresentou um aumento significante com a expansão.

Neste mesmo ano, $\mathrm{HAAS}^{44}$, comentou sobre os fenômenos previsíveis que poderiam ocorrer com a $E R M$, já descritos anteriormente. Descreveu os casos mais indicados para este tipo de procedimento : 1) casos cirúrgicos e não cirúrgicos de Classe III, 2) casos de deficiência maxilar real e relativa, 3) casos de capacidade nasal insuficiente, 4) pacientes fissurados e 5) casos com problemas de espaço no arco superior, na tentativa de se evitar as extrações dentárias. Em todo o artigo, o autor demostrou a necessidade de uma ancoragem máxima (dentomucossuportada), para promover um maior movimento ortopédico do que ortodôntico durante a expansão, obtendo sempre uma sobrecorreção do segmento posterior, para um bom relacionamento das bases ósseas e para a estabilidade do tratamento.

Utilizando-se de telerradiografias em norma frontal e lateral, radiografias oclusais, fotografias intra-bucais e modelos de gesso, WERTZ ${ }^{111}$, em 1970, analisou 60 pacientes com atresia maxilar, para observar as alterações decorrentes da ERM. A amostra consistiu de 37 pacientes do sexo feminino, com idades variando entre 7 e 29 anos e 23 pacientes do sexo masculino, com idades entre 8 e 14 anos. A documentação foi realizada no início do tratamento, imediatamente após a expansão e após a contenção (aproximadamente 3 meses). 
Como complemento, realizou o mesmo procedimento em dois crânios secos, para obter maiores informações sobre as respostas esqueléticas. Dentre suas observações, destacam-se :

- não se observaram diferenças relacionadas ao sexo, porém, nos pacientes mais velhos, as respostas esqueléticas se apresentaram com menor magnitude;

- deslocamento da maxila para baixo em todos os casos e para frente apenas em casos isolados;

- movimento lingual dos incisivos superiores;

- deslocamento mandibular no sentido horário, acompanhando o deslocamento maxilar, com normalização de seu posicionamento no período de contenção;

- em uma vista frontal, notou-se um aumento na cavidade nasal e a abertura da sutura palatina mediana em forma triangular, com base voltada para a cavidade bucal e ápice para a sutura frontomaxilar, devido à maior resistência óssea nesta região;

- por uma vista oclusal, a abertura da sutura palatina mediana também ocorreu de forma triangular, com a base voltada para a espinha nasal anterior;

- os achados nos crânios secos, fundamentaram as observações clínicas.

DIPAOLO $^{34}$, em 1970, destacou a importância do correto diagnóstico das mordidas cruzadas posteriores, uma vez que estas podem ser esqueléticas (Tipo 1- deficiência da base apical) ou dentoalveolares (Tipo 2 - inclinações dentárias indesejáveis). Esta diferenciação pode ser realizada clínica e cefalometricamente (radiografia póstero-anterior), auxiliando na correta definição do tipo de aparelho a ser empregado. Nos casos de deficiência real da maxila, os aparelhos 
dentomucossuportados foram os mais indicados, devido à máxima ancoragem necessária para a ruptura da sutura palatina mediana. Muitos casos de mordidas cruzadas dentoalveolares poderiam ser corrigidos sem a utilização da $E R M$ e sim com dispositivos removíveis, elásticos, torques e arcos mais expandidos, durante o tratamento ortodôntico convencional. Além disto, o autor contra-indicou este procedimento para pacientes com padrão de crescimento excessivamente vertical, devido ao aumento da altura facial ântero-inferior (AFAI).

Com a intenção de investigar as alterações que a ERM acarretava nas estruturas craniofaciais (deslocamento e remodelação óssea), GARDNER; KRONMAN $^{37}$, em 1971, analisaram seis Macacus rhesus fêmeas, sendo três do grupo experimental, submetidos a $E R M$ com um expansor fixo, e três do grupo controle. Após uma semana da cimentação, iniciaram-se as ativações, que foram realizadas a cada três dias, durante um período de um mês ou até a obtenção de uma mordida cruzada inversa. Ao final da fase ativa, injetou-se intramuscularmente $10 \mathrm{mg} / \mathrm{kg}$ de oxitetraciclina em todos os animais, com a finalidade de corar e facilitar a visualização de ossos neoformados, por causa da sua fácil absorção e fluorescência na luz ultravioleta. Os animais foram sacrificados sete dias após, tendo seus crânios limpos e preparados para a análise com a luz natural e ultravioleta. Como resultados, observaram :

- abertura da sincondrose esfenocciptal (0,5 a $1 \mathrm{~mm})$, o que pôde explicar o deslocamento da maxila para baixo e para frente, em decorrência da $E R M$, citado por outros autores;

- abertura da sutura palatina mediana;

- todas as suturas do palato, pré-maxila e maxila apresentaram áreas sem absorção de oxitetraciclina, porém, aparentemente estas suturas apresentaram alterações durante a expansão; 
- as suturas lambdóide, parietal e sagital mediana do crânio demonstraram grande desorganização, chegando a deslocamentos de até 1,5 $\mathrm{mm}$;

- a fluorescência da oxitetraciclina demonstrou o estímulo de crescimento ou remodelação nos ossos próximos à sutura palatina mediana.

No ano de 1971, ALPINER; BEAVER ${ }^{6}$, após uma breve revisão de literatura, destacaram as principais indicações e contra-indicações para a ERM. As indicações foram as más oclusões de Classe III, não tratadas cirurgicamente, a pseudo Classe III, a deficiência maxilar real com a mandíbula normal, a deficiência maxilar relativa, ou seja, maxila com um tamanho normal e a mandíbula excessivamente grande, os pacientes respiradores bucais crônicos, que geralmente apresentam um palato profundo, as más oclusões de Classe I, com mordidas cruzadas posteriores e os pacientes fissurados. O prognatismo maxilar ou biprotrusão, os pacientes e pais não colaboradores e as mordidas cruzadas de apenas um elemento, foram citadas como contra-indicações. Concluem que o procedimento de $E R M$ apresenta-se como a primeira fase do tratamento ortopédico-ortodôntico, porém em alguns casos tratados precocemente (6 a 10 anos), esta mecânica pode estabelecer totalmente a função e a harmonia dentoesquelética.

BYRUN JÚNIOR ${ }^{21}$, neste mesmo ano, analisou trinta casos tratados com $E R M$, para avaliar as alterações dentárias e esqueléticas verticais e ânteroposteriores relacionadas com este procedimento. Nesta amostra, havia pacientes de ambos os sexos, com as idades variando de 8 a 14 anos e com más oclusões de Classe I, II e III. As telerradiografias em norma lateral foram obtidas nas 
fases pré-tratamento e pós-contenção. O período de ativação durou em média 3 semanas. Os resultados observados foram :

- movimento significante da maxila para baixo e praticamente nulo para frente;

- pequena extrusão dos primeiros molares superiores;

- rotação da mandíbula para baixo e para trás (sentido horário), aumento do ângulo do plano mandibular e conseqüente abertura da mordida;

- aumento nas alturas faciais ântero-superior e inferior.

As reações ósseas e teciduais (tecidos conectivos) na região da sutura palatina mediana, mediante a aplicação de forças intensas, foram estudadas por MURRAY; CLEALL ${ }^{76}$, em 1971, utilizando uma amostra de seis animais Macacus rhesus fêmeas, sendo quatro do grupo controle e dois do grupo experimental. Instalaram-se aparelhos expansores convencionais (dentomucossuportados) e a ativação inicial foi de $3 / 4$ de volta e $1 / 4$ nos dias subseqüentes. Os quatro animais do grupo experimental foram sacrificados nos tempos de 24 horas, 4 dias, 7 dias e 14 dias após a primeira ativação. Sacrificaram-se também os animais do grupo controle e utilizaram-se os dados obtidos como referência para as comparações com o grupo experimental. A maxila, juntamente com os dentes e processos alveolares, foram removidos para as análises radiográficas e microscópicas. Os resultados sugerem as seguintes conclusões :

- a abertura da sutura palatina mediana, em decorrência das forças de expansão, foi observada entre o quarto e sétimo dia de ativação;

- o mecanismo de abertura envolveu uma série de eventos : 1) adaptação do tecido conectivo sutural à aplicação de forças pesadas; 2) reabsorção do 
tecido conectivo para permitir a separação dos processos ósseos; 3) grande deposição óssea, para manter a morfologia da sutura;

- durante os estágios iniciais da expansão, os dentes superiores apresentaram movimento de inclinação, porém após o $14^{\circ}$ dia, este movimento se apresentou de corpo.

No ano de 1972, WHITE ${ }^{113}$, realizou um estudo cefalométrico comparativo das alterações esqueléticas pré e pós-tratamento, de 30 pacientes tratados com a ERM. As telerradiografias em norma lateral foram obtidas no início do tratamento e no final da fase de contenção (3 meses), e as telerradiografias em norma frontal foram obtidas no início do tratamento e no final da fase de ativação. Não se observaram alterações significantes no relacionamento da maxila, mandíbula, plano palatino e plano oclusal, porém a mandíbula apresentou um pequeno movimento para baixo e para trás, devido às alterações na oclusão. Na visão frontal, não se observou aumento na distância interorbital, porém as larguras internasal, da sutura palatina mediana e do aparelho aumentaram significantemente, indicando que a terapia produziu uma abertura triangular da sutura palatina mediana, com ápice na área nasal.

Segundo BIEDERMAN; CHEN $^{16}$ em 1973, a má oclusão de Classe III verdadeira, apresenta um envolvimento esquelético da maxila (deficiência), da mandíbula (prognatismo) ou uma associação entre ambas. Relatou dois casos de Classe III (irmãos), tratados com a ERM, utilizando disjuntores dentossuportados. Além da correção da mordida cruzada posterior, o deslocamento da maxila para frente e para baixo, auxiliou na correção da mordida cruzada anterior. $\mathrm{O}$ autor ainda destacou, em ordem decrescente, as 
suturas mais envolvidas neste tipo de procedimento : palatina mediana, frontonasal, zigomaticomaxilar e zigomaticotemporal.

Em uma entrevista concedida à "Journal Clinical Orthodontics" no ano de 1973, $\mathrm{HAAS}^{45}$, comentou de forma bem didática, sobre todos os aspectos relacionados à expansão rápida da maxila, tais como suas indicações, contraindicações, alterações esqueléticas e dentárias, vantagens do aparelho dentomucossuportado, protocolo de ativação, contenção e recidiva, entre outros.

Com o advento da colagem direta, COHEN; SILVERMAN ${ }^{29}$, neste mesmo ano, divulgaram um aparelho para ERM com cobertura de resina e colado nos dentes póstero-superiores. Segundo os autores, este tipo de expansor apresentou algumas vantagens em relação ao Haas, Hyrax e Minne-expander : 1) não existe a necessidade de confecção de bandas; 2) simplicidade de instalação; 3) potencial de intrusão dos dentes póstero-inferiores; 4) mais indicado para pacientes com crescimento vertical.

Objetivando confirmar algumas alterações descritas pela literatura nos casos tratados com a $E R M$ e verificar se este procedimento causaria algum efeito na face média dos macacos Macaca mulata, HOFFER;WALTERS ${ }^{51}$, em 1975, estudaram dez animais que estavam na fase da dentadura mista, com idades equivalentes a 7-12 anos nos humanos. Estes foram divididos em três grupos, com dois animais experimentais e dois controles para cada um (os animais do grupo controle foram iguais para o grupo II e III ). Nos animais do grupo experimental, realizou-se a $E R M$ durante um período de três semanas e o tempo de contenção variou em dois, quatro ou seis meses. Para a observação da quantidade de reabsorção e de aposição óssea, os animais recebiam 
periodicamente injeções de oxitetraciclina, absorvida pelos ossos neoformados, apresentando-se fluorescente à luz ultravioleta. Após o sacrifício dos animais, a preparação dos crânios e a análise deste material, observaram as seguintes alterações nos animais do grupo experimental :

- abertura da sutura palatina mediana (5,5 até $8 \mathrm{~mm})$;

- expansão do arco dentário superior, do espaço nasal e da abóbada palatina;

- pequeno aumento na largura bizigomática e nas dimensões transversais do arco inferior;

- inclinação vestibular dos dentes póstero-superiores ao início do tratamento, porém ao final da fase experimental, estes dentes se apresentavam com suas angulações normais;

- neoformação óssea na área da sutura palatina mediana.

$\mathrm{Na}$ tentativa de elucidar alguns pontos ainda duvidosos em relação aos efeitos da $E R M$ e a redução da resistência nasal, HERSHEY; STEWART; WARREN $^{50}$, em 1976, analisaram 17 pacientes, sendo 6 do sexo masculino e 11 do sexo feminino (14 respiradores bucais), com idades entre 11 e 14 anos, que necessitavam desta terapia para a correção da atresia do arco superior. Utilizaram o expansor dentomucossuportado em seis pacientes e o dentossuportado no restante. Ao final da fase de ativação, o aparelho foi mantido como contenção por três meses. Realizou-se o estudo com o auxílio de modelos de gesso, telerradiografias em norma frontal e medidas da resistência nasal, tomadas nas fases pré-expansão, pós-expansão e pós-contenção. O valor da resistência respiratória nasal foi obtida com auxílio de aparelhos específicos para a verificação do fluxo de ar e aplicação dos valores em fórmulas próprias. Verificaram que : 
- a $E R M$ produziu uma redução significante na resistência respiratória nasal e esta permaneceu estável após os três meses de contenção, apesar do aumento estatisticamente significante na largura da cavidade nasal;

- não existiu uma grande correlação entre a quantidade de expansão dos primeiros molares superiores e as alterações na resistência nasal;

- não houve relação entre a redução da resistência nasal e a melhoria da capacidade de respiração nasal, quando os pacientes foram questionados;

- não se observaram diferenças entre os dois tipos de aparelhos utilizados, com relação à expansão dos primeiros molares superiores, aumento da cavidade nasal e alterações na resistência nasal;

- os pacientes que necessitavam da ERM, devido à atresia maxilar, possuíam uma resistência respiratória elevada e que este tratamento reduziu os valores aos níveis observados em pacientes com arcos normais;

- os pacientes respiradores bucais, demostraram uma diminuição considerável na resistência nasal, podendo ser comparada aos respiradores nasais.

MONDRO; LITT $^{70}$, em 1977, descreveram os procedimentos de confecção, instalação, ativação e remoção de um aparelho expansor dentomucossuportado, colado aos dentes superiores, composto por um corpo rígido de acrílico, que recobre o palato e os dentes de ancoragem e um parafuso expansor. Esta porção de acrílico que recobre os dentes póstero-superiores, deve ser desgastada para haver contatos bilaterais iguais com os dentes inferiores durante a oclusão. Como vantagens, citaram : 1) simples confecção; 2) fácil remoção; 3) mais barato; 4) alterações comparáveis as do Haas. Para a remoção deste aparelho, indicaram a utilização de brocas de alta rotação e de alicates saca-banda. 
Neste mesmo ano, BROGAN ${ }^{19}$, baseando-se na hipótese de que a $E R M$ causaria um aumento na largura nasal e conseqüentemente uma diminuição na resistência nasal respiratória, descreveu as principais observações em 516 pacientes respiradores bucais, com mordidas cruzadas posteriores uni ou bilaterais e/ou portadores de Classe III, tratados com esta mecânica. Telerradiografias em norma lateral e frontal foram obtidas antes da expansão, imediatamente após a ativação total e seis meses após a expansão. Observou que este tratamento foi eficiente, produzindo forças ortopédicas para o aumento significante e estável da largura maxilar, corrigindo as más oclusões citadas anteriormente. $\mathrm{O}$ autor recomendou a indicação desta terapia para os pacientes com deficiências respiratórias, associadas a atresia maxilar, exemplificando com o sucesso nos tratamentos de indivíduos com desvio de septo. Ainda alertou para a necessidade de um aparelho rígido (máxima ancoragem), capaz de suportar as forças de expansão pesadas (ortopédicas).

Com uma amostra bastante heterogênea, composta por 56 pacientes de várias clínicas particulares, com idades variando de 8 a 29 anos e tratados com diferentes tipos de disjuntores palatinos, WERTZ; DRESKIN ${ }^{112}$, em 1977, analisaram as alterações dentoesqueléticas decorrentes da ERM. Para isto, obtiveram telerradiografias em norma frontal e lateral nas fases pré-expansão, imediatamente pós-expansão, pós-contenção e ao final do tratamento ortodôntico corretivo. Por problemas na documentação, o número de pacientes da amostra diminuiu para 51 ao final do período de contenção e para 27 no final do tratamento corretivo. As principais observações foram divididas em duas fases : 1) imediatamente pós-expansão, observaram uma movimentação do ponto A para frente , aumento na largura da cavidade nasal (1,5 mm em média), 
na largura da maxila (2,5 mm em média), na distância intermolares superiores (6,5 mm em média) e inferiores (0,5 mm em média); 2) na fase pós-contenção, observaram uma recidiva no movimento do ponto $\mathrm{A}(0,5 \mathrm{~mm})$, constância na largura da cavidade nasal e um pequeno aumento na distância intermolares superiores $(0,5 \mathrm{~mm}$ em média), devido à ação de forças residuais. Com a observação de todas as fases, chegaram a conclusão que :

- a $E R M$ foi efetiva em todos os pacientes, porém naqueles com idades mais avançadas, os efeitos ortodônticos superaram os efeitos ortopédicos;

- no sentido vertical, a maxila se movimentou para baixo em todos os casos, porém, no sentido ântero-posterior demostrou uma grande variação, com pequenos movimentos para trás e deslocamentos significantes para frente. Estas alterações não foram evidenciadas após a contenção.

- o aumento da largura esquelética da maxila permaneceu estável nos pacientes jovens, porém naqueles com mais idade, a recidiva foi freqüente.

Para estudar a influência da $E R M$ sobre os dentes inferiores, GRYSON ${ }^{40}$, em 1977, analisou 38 pacientes tratados com o expansor palatino tipo Haas (dentomucossuportado), com idade média de 10 anos e meio ao início do tratamento. A documentação ortodôntica completa foi realizada no início do tratamento e apenas modelos de gesso foram obtidos novamente ao final da ativação e da contenção ( 3 meses). Com um compasso de precisão, realizaramse as medidas das distâncias intermolares e intercaninos superiores e inferiores, notando que :

- os aumentos médios das distâncias intercaninos e intermolares inferiores foram de $0,2 \mathrm{~mm}$ e $0,4 \mathrm{~mm}$, respectivamente;

- a expansão do arco inferior deu-se basicamente pela alteração das forças de oclusão e pelo equilíbrio muscular; 
- apesar de um pequeno aumento das distâncias intercaninos e intermolares inferiores, não se justifica a realização da $E R M$ apenas para esta finalidade.

Avaliando as alterações dentárias e esqueléticas decorrentes da $E R M$ e principalmente a estabilidade destas após um período de cinco anos, LINDERARONSON; LINDGREN ${ }^{61}$, em 1979, estudaram 23 pacientes (7 do sexo masculino e 16 do sexo feminino), com idade média de 14 anos e 4 meses, no início do tratamento, tratados com a disjunção da sutura palatina mediana. Para análise, utilizaram modelos de gesso confeccionados antes e imediatamente após a expansão, ao final da contenção e ao final do período de observação. As telerradiografias em norma lateral foram obtidas no início do tratamento, ao final da retenção e ao final da observação. Destacam-se como principais resultados :

- aumento médio de $6 \mathrm{~mm}$ na distância intermolares superiores do início do tratamento ao final do período de contenção. Após cinco anos, esta medida recidivou aproximadamente $50 \%$;

- aumento médio de 2,1 mm na distância intercaninos superiores, neste mesmo período, e uma recidiva de $77 \%$ ao final de cinco anos;

- sobremordida e sobressaliência normais, após cinco anos de observação;

- aumento das alturas faciais anteriores total e inferior após a expansão, que se normalizou durante os anos subseqüentes.

BERLOCHER; MÜELLER; TINANOFF ${ }^{13}$, em 1980, pesquisaram se a $E R M$, utilizada para a correção da atresia maxilar, aumentaria o perímetro do arco superior, reduzindo assim a discrepância dente/osso. A amostra foi 
constituída por 29 pacientes (10 fissurados), portadores de mordida cruzada posterior e com idades oscilando entre 3 e 7 anos. Analisaram as medidas do perímetro e da largura do arco pré e pós-tratamento nos modelos de gesso e concluíram que todos os pacientes demostraram um aumento no perímetro do arco e nas distâncias intercaninos e intermolares superiores (média de $4 \mathrm{~mm}$ para todas as medidas). Os autores também observaram uma grande variação nas correlações entre as alterações nas dimensões transversais do palato e as alterações no perímetro do arco.

Salientando a importância do correto diagnóstico para o sucesso do plano de tratamento e a necessidade da correção das más oclusões nos três planos do espaço (transversal, vertical e ântero-posterior), $\operatorname{HAAS}^{46}$, em 1980, publicou mais um artigo clássico sobre a ERM. Enfatizou as principais indicações desta e alertou que esta não possuí contra-indicações, uma vez que existem mecanismos para evitar alguns efeitos indesejáveis decorrentes deste procedimento. Comentou sobre o tratamento, as alterações e principalmente sobre a estabilidade de dez casos, sendo que seis já haviam sido mostrados em artigos anteriores, observados após cerca de 20 anos do final do tratamento. Como principais conclusões, citou :

- os aumentos médios das larguras da cavidade nasal e da base apical foram, respectivamente $4,5 \mathrm{~mm}$ e $9 \mathrm{~mm}$. Após o período de observação, estas medidas mostraram-se estáveis;

- em seis dos dez pacientes, não se observou recidiva na distância intermolares superiores nos períodos pós-contenção e pós-observação;

- a necessidade do uso de contenção no arco superior por um período mínimo de quatro anos e no arco inferior, de seis anos; 
- aumento da distância intercaninos e intermolares inferiores com a expansão, devido às alterações na oclusão e ao equilíbrio muscular (bucinador e língua);

- estabilidade total no aumento da distância intercaninos inferiores (4 a $5 \mathrm{~mm}$ ). O autor ainda demonstrou a importância da utilização de ancoragem máxima (aparelho dentomucossuportado) para a obtenção dos efeitos ortopédicos desejados.

Com o objetivo de demonstrar a necessidade do trabalho conjunto entre o cirurgião bucomaxilofacial, o ortodontista e o protético nos casos de ERM em pacientes adultos (fissurados), BRUDVIK; NELSON ${ }^{20}$, em 1981, descreveram a confecção e a instalação de dois aparelhos, compostos por uma prótese metálica e um parafuso expansor. Se houvesse a necessidade de uma abertura da sutura palatina mediana apenas na região anterior, poder-se-ia associar um dispositivo na região posterior do aparelho, para esta finalidade. Além disto, o encapsulamento dos dentes posteriores, para a obtenção de uma maior ancoragem, também poderia ser realizado.

Utilizando a microscopia eletrônica de varredura, BARBER; $\operatorname{SIMS}^{10}$ em 1981, avaliaram as reabsorções radiculares externas decorrentes da $E R M$, em uma amostra de nove pacientes (cinco do sexo feminino e quatro do sexo masculino) que necessitavam da expansão do arco superior e posteriormente da extração dos quatro pré-molares, devido à grande discrepância de modelo. Os pacientes foram divididos em dois grupos e a documentação ortodôntica completa, incluindo radiografias periapicais dos pré-molares, foi realizada no início e no final do tratamento. No grupo I, o primeiro pré-molar esquerdo não foi utilizado como dente de ancoragem, apesar de ter sido movimentado com a 
expansão rápida da maxila. Realizaram-se as ativações duas vezes por dia. Após a correção das mordidas cruzadas posteriores, os aparelhos foram mantidos como contenção (períodos variados de 0 a 36 semanas), até a extração dos prémolares superiores e inferiores para a análise. Puderam observar :

- reabsorção radicular em todos os pré-molares de ancoragem, principalmente na face vestibular (terço cervical e médio);

- relação direta entre o grau de reabsorção e o tempo de contenção, ou seja, os dentes que permaneceram mais tempo na cavidade bucal (maior tempo de contenção) apresentaram maiores graus de reabsorção;

- os primeiros pré-molares inferiores e o primeiro pré-molar esquerdo do grupo I, não apresentaram sinais de reabsorção;

- níveis significantes de reabsorção, nos dentes extraídos imediatamente após a expansão;

- predominância do processo reparador (cemento celular) após o término da expansão, porém a reabsorção prolongou-se no período de contenção, devido à ação das forças residuais;

- pequenas reabsorções na face palatina, principalmente no terço apical;

- falta de confiabilidade das radiografias periapicais no diagnóstico de reabsorções radiculares, uma vez que esta não obtém imagens das áreas mais atingidas (face vestibular) dos dentes de ancoragem.

CHACONAS; CAPUTO ${ }^{26}$, em 1982, com o propósito de observar as alterações no complexo craniofacial decorrentes da expansão da maxila, realizaram um estudo comparativo entre os aparelhos Haas, Hyrax, Minneexpander, quadrihélice e uma placa superior removível, com parafuso expansor. Este estudo foi realizado em duas fases : $1^{\mathrm{a}}$ ) determinação da relação entre a ativação e a quantidade de força liberada. Utilizaram modelos com todos os 
aparelhos, adaptados a um mecanismo com células sensíveis, para a verificação da magnitude das forças. $2^{\mathrm{a}}$ ) Visualização fotoelástica das forças, ou seja, como as forças são transmitidas para os dentes de suporte e para o complexo craniofacial. Para isto, duplicou-se um crânio humano, confeccionando-se um modelo anatômico tridimensional com materiais birrefringentes, para a simulação de todas as estruturas. Outros materiais birrefringentes foram utilizados para a confecção dos dentes e ligamentos periodontais. Todos os aparelhos foram instalados e ativados neste modelo, para posterior análise. Concluíram que :

- os aparelhos Haas, Hyrax e o aparelho removível, desde que estável na cavidade bucal, produziram as forças ortopédicas mais significantes com as ativações subseqüentes;

- o aparelho Minne-expander, apresentou a menor liberação de força a cada ativação;

- o quadrihélice não produziu forças ortopédicas, causando principalmente alterações dentoalveolares. Nos casos de pacientes jovens, podem ocorrer efeitos ortopédicos;

- a força produzida pelos aparelhos fixos localizou-se inicialmente na região anterior do palato, caminhando para posterior, em direção aos ossos palatinos;

- as forças produzidas pelo aparelhos Haas, Hyrax e Mine-expander foram irradiadas superiormente pelas lâminas perpendiculares dos ossos palatinos até as estruturas anatômicas mais profundas, como o processo pterigóide do osso esfenóide, o processo zigomático da maxila e a porção mediana das órbitas (união dos ossos nasais e lacrimais), afetando as suturas zigomaticomaxilar e zigomaticotemporal; 
- alterações semelhantes foram observadas no aparelho removível, porém com as ativações seguidas, este perde a retenção, decaindo a força exercida e conseqüentemente a sua eficiência.

Neste mesmo ano, $\mathrm{HOWE}^{53}$ demonstrou a efetividade de um expansor colado aos dentes superiores, com a apresentação de um caso clínico. Este aparelho é composto por um parafuso expansor, um corpo de metal que envolve os dentes de ancoragem e sobre este corpo, uma fina camada de resina. A superfície oclusal dos elementos dentários deve permanecer livre. Segundo o autor existem algumas vantagens em relação ao Haas e ao Hyrax : 1) fácil confecção devido à ausência de bandas; 2) fácil instalação; 3) higiênico, comparável ao Hyrax, devido à ausência de suporte mucoso (resina); 4) pode ser utilizado em pacientes na fase da dentadura decídua e nos casos severos de mau posicionamento dentário. Como desvantagens, cita a fase de remoção e as possíveis descalcificações dentárias, se a higiene não for satisfatória.

SPOLYAR ${ }^{102}$, em 1984, com dez anos de experiência na utilização de disjuntores colados, descreveu os procedimentos de confecção, quatro casos clínicos e as principias vantagens deste aparelho. Este possui um parafuso expansor e uma porção de acrílico que envolve totalmente os dentes de ancoragem, com contatos bilaterais iguais nos dentes inferiores. Não acreditava que a cobertura de acrílico (aproximadamente $3 \mathrm{~mm}$ ) seria capaz de causar a intrusão do complexo dentoalveolar e assim inibir o aumento da AFAI em decorrência da ERM, principalmente pelo curto período que este aparelho permaneceu na cavidade bucal. Dentre algumas vantagens, destacou : 1) fácil confecção; 2) abertura da mordida, facilitando a tração reversa da maxila; 3) 
utilização em casos de expansão assistida cirurgicamente (variação das unidades de ancoragem).

Descrevendo um caso clínico de uma paciente do sexo feminino, 11 anos e 7 meses de idade, tratada com o aparelho tipo Haas, SATO; VIGORITO; CARVALHO $^{86}$, em 1985, avaliaram as alterações decorrentes da ERM, utilizando telerradiografias em norma frontal. Analisaram quatro medidas cefalométricas, pré e pós-expansão, comparando-as com valores normativos. Pode-se detectar uma normalização dos problemas esqueléticos observados inicialmente. Salientaram ainda a importância da utilização das radiografias póstero-anteriores para o diagnóstico das mordidas cruzadas posteriores e para a avaliação das alterações citadas anteriormente.

BISHARA; STALEY ${ }^{17}$, em 1987, realizaram uma extensa revisão de literatura sobre as implicações clínicas da expansão maxilar, dando ênfase a ERM. Comentaram sobre as indicações, contra-indicações, tipos de aparelhos, alterações dentoesqueléticas decorrentes da $E R M$, influência da idade neste procedimento, a quantidade de ativação e de força aplicada e conseqüentemente a presença de forças residuais, métodos de contenção, recidiva, entre outros assuntos. Finalizam o artigo, destacando 12 conselhos clínicos para os pacientes submetidos à ERM.

Com o intento de demostrar uma técnica cirúrgica conservadora para a $E R M$, que minimizaria o custo, o trauma e o risco cirúrgico, realizada em pacientes adultos que necessitassem de uma expansão do arco superior, ALPERN; YUROSKO 5 , em 1987, descreveram os procedimentos e suas vantagens. Além disto, devido à problemas observados no aparelho tipo Haas, os 
autores indicaram um expansor com blocos de acrílico nos dentes posteriores, citando algumas vantagens: 1) eliminação das forças horizontais da oclusão, que poderiam interferir na expansão da maxila; 2) expansões bilaterais simétricas (mesma magnitude); 3) tratamento, sem cirurgia de pacientes até 20 anos (sexo feminino) e 25 (sexo masculino); 4) controle vertical durante a $E R M ; 5)$ pode-se associar ganchos na altura dos caninos, para o uso da máscara facial. Porém, relataram que uma das maiores desvantagens é a remoção, necessitando de brocas de alta rotação e alicate saca-banda.

Avaliando os valores da resistência nasal respiratória nas fases préexpansão, pós-expansão e pós-contenção, HARTGERINK; VIG; $\mathrm{ABBOT}^{48}$, em 1987, estudaram uma amostra de 38 pacientes submetidos à $E R M$, com idade média de 11 anos e um grupo controle, composto por 24 pacientes, com idade média de 12 anos. Foram reavaliados (9 a 12 meses) 33 pacientes no grupo experimental e 18 pacientes no controle para a observação da estabilidade das alterações conseguidas com a expansão. A resistência nasal foi medida com a utilização de aparelhos apropriados, em quatro condições distintas : 1) respiração normal; 2) respiração com a dilatação das narinas com tubos de tamanhos compatíveis; 3) respiração após cinco minutos da administração de descongestionante nasal; 4) associação do descongestionante e da dilatação nasal. Observaram que :

- os pacientes do grupo experimental, apresentavam uma resistência nasal maior ao início do tratamento, em comparação ao grupo controle;

- a ERM diminuiu a resistência nasal em alguns casos, mantendo-se estável por um período de um ano. Em $35 \%$ do grupo experimental, observou-se uma estabilidade ou até uma diminuição desta resistência nasal; 
- nos pacientes do grupo controle, ocorreu uma pequena diminuição da resistência nasal, explicada pelo crescimento e desenvolvimento craniofacial, porém nos casos em que se utilizou o descongestionante, as alterações foram mais significantes;

- em todos os tempos e modos estudados pôde-se observar uma grande variação individual, portanto, a $E R M$ não demonstrou confiabilidade como um método para a redução da resistência respiratória nasal em todos os pacientes.

Para observar as alterações nas distâncias intercaninos e intermolares inferiores após a $E R M$ (aparelho tipo Haas) e o tratamento ortodôntico corretivo, além de sua estabilidade e relação com o tipo facial dos pacientes, SANDSTROM; KLAPPER; PAPACONSTANTINOU ${ }^{81}$, em 1988, estudaram dois grupos de pacientes. Para a análise da distância intercaninos, utilizaram 17 pacientes, com idade média de 14 anos e que permaneceram com uma contenção lingual fixa por um período médio de 5 anos e 6 meses. Os modelos póstratamento foram obtidos dois anos após a remoção da contenção. Para a análise da distância intermolares, a amostra consistiu de 22 pacientes, com idade média de 12 anos e 6 meses de idade. Os modelos para o estudo foram obtidos após um período médio de 8 anos e 8 meses. Existiu um aumento estatisticamente significante nas distâncias estudadas após a $E R M$ e o tratamento ortodôntico com aparelhagem fixa e que, apesar da recidiva observada no período de contenção, estes valores permaneceram significantes na análise final. Não se observaram correlações entre a quantidade de aumento nas distâncias e o tipo facial e a idade dos pacientes analisados. 
Realizando uma extensa revisão de literatura, somada à grande experiência clínica, SILVA FILHO; CAPELOZZA FILHO ${ }^{90}$, em 1988, elucidaram os principais pontos sobre a $E R M$, tais como as suas indicações, os efeitos ortodônticos e ortopédicos, o protocolo de ativação, a contenção, a recidiva, a possível sintomatologia dolorosa e a expansão em pacientes adultos. A ampla abordagem do assunto foi ilustrada com vários casos clínicos. Um dos pontos de destaque é a ativação, realizada com 1 volta completa do parafuso por dia, sendo diferente da observada na literatura.

Em um estudo comparativo entre dois aparelhos de expansão lenta da maxila (Minne-expander), um bandado e outro colado, MOSSAZ; MOSSAZ; $\operatorname{MOSSAZ}^{73}$, em 1989, verificaram que a cobertura de acrílico pode eliminar as interferências durante o deslocamento lateral da maxila, diminuindo a resistência à expansão. Com uma amostra de 10 pacientes, sendo seis do sexo masculino e quatro do sexo feminino, divididos em dois grupos (idades entre 8 e 12 anos), avaliando-os com a observação dos implantes metálicos inseridos antes do tratamento e com o auxílio de modelos de gesso, telerradiografias em norma frontal e lateral e radiografias oclusais, chegaram às seguintes conclusões :

- clinicamente não se observou abertura do diastema entre os incisivos centrais superiores, característico da ERM;

- a dificuldade na higienização e na remoção do aparelho colado podem ser indicadas como desvantagens desta técnica;

- as alterações dentoesqueléticas foram idênticas nos dois grupos analisados. 


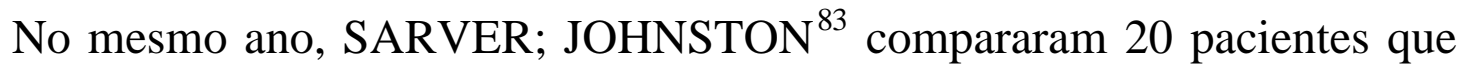
utilizaram o expansor com cobertura de acrílico colado aos dentes superiores e 60 pacientes tratados com o expansor tipo Haas, da amostra de WERTZ ${ }^{111}$. A ativação foi realizada duas vezes por dia e o período de contenção foi de aproximadamente três meses. Utilizaram apenas as telerradiografias em norma lateral, principalmente para a análise da magnitude do deslocamento vertical da maxila nos dois tipos de aparelhos. Observaram as seguintes características nos pacientes que utilizaram o aparelho colado: 1) o deslocamento ântero-inferior da maxila, associado à ERM, pôde ser anulado ou diminuído com este aparelho; 2) além de atuar na expansão, limitou as alterações na dimensão vertical, produzindo forças intrusivas em ambos os arcos, como um aparelho funcional (BiteBlock - Bloco de Mordida Posterior); 3) suave movimento póstero-superior da ENP; 4) movimento para baixo e para trás da ENA. Baseados nos resultados, os autores sugeriram este tipo de aparelho no tratamento de pacientes com ângulo do plano mandibular obtuso, face longa, tendência à mordida aberta anterior, uma vez que o deslocamento inferior da maxila é desfavorável nos pacientes com crescimento vertical. Além disto, este aparelho pode ser indicado para pacientes com Classe II que necessitam da $E R M$, uma vez que o deslocamento da maxila para frente apresentou-se em menor magnitude.

Defendendo a correção precoce das mordidas cruzadas posteriores, SILVA FILHO; VALADARES NETO; ALMEIDA ${ }^{96}$, em 1989, discorreram sobre as principais vantagens e motivos para esta intervenção, se possível na dentadura decídua : 1) obtenção de respostas mais favoráveis, com aparelhos simplificados, devido à grande bioelasticidade óssea nas crianças; 2) redirecionamento dos germes do dentes permanentes para posições mais favoráveis; 3) proporcionar um melhor relacionamento entre as bases ósseas, 
permitindo o crescimento e o desenvolvimento normais; 4) eliminação das posições inadequadas da ATM, estabelecendo relações simétricas entre o côndilo e a fossa articular; 5) promover uma trajetória mandibular normal; 6) contribuir para a auto-imagem mais favorável da criança, principalmente nos casos onde há comprometimento estético. Além disto, os autores comentaram sobre as principais características dos aparelhos removíveis e fixos, utilizados para a expansão lenta e rápida da maxila. Os removíveis, para a expansão lenta são os aparelhos com mola Coffin, Splint Coffin e parafusos expansores. O quadrihélice, o bihélice e o arco em W são aparelhos fixos para expansão lenta, já o aparelho tipo Haas e Hyrax, são utilizados para a ERM. Todos estes são exemplificados com casos clínicos e uma grande parte teórica para elucidar os pontos mais importantes.

Investigando o potencial de aumento no perímetro do arco superior e as alterações dentárias decorrentes da ERM, ADKINS; NANDA; CURRIER ${ }^{1}$, em 1990, analisaram 21 pacientes, com idades variando de 11 anos e 6 meses até 17 anos, que necessitavam da $E R M$ como parte inicial do tratamento ortodôntico. Para a análise das alterações no arco inferior, apenas 16 pacientes foram incluídos, uma vez que cinco estavam com aparelho fixo, o que poderia interferir nos resultados finais. Todos os pacientes foram tratados com o aparelho tipo Hyrax e analisados com modelos de gesso obtidos antes da expansão e após a contenção (período médio de 14,5 semanas). Para facilitar as medições, os pontos de referência foram marcados nos modelos, que foram fotografados em uma visão oclusal, com uma máquina $35 \mathrm{~mm}$ e posteriormente digitalizados. As medidas para o estudo incluíam as distâncias intercaninos, interpré-molares e intermolares superiores e inferiores, perímetro e comprimento 
do arco superior, além das angulações dos molares e pré-molares superiores. Após a análise estatística dos dados, puderam observar :

- as expansões médias nas regiões de caninos, pré-molares e molares superiores foram, respectivamente de $2,9 \mathrm{~mm}, 6,1 \mathrm{~mm}$ e $6,5 \mathrm{~mm}$;

- diminuição média de 0,4 mm no comprimento do arco;

- inclinação lingual dos incisivos superiores no período de contenção;

- após a correção do movimento ântero-posterior dos incisivos, o perímetro do arco mostrou um aumento médio de 4,7 mm;

- inclinação bastante variável dos pré-molares e molares superiores para vestibular, sem demonstrar relação direta com a idade, largura inicial do palato e quantidade de expansão;

- aumento do perímetro do arco superior de aproximadamente 0,7 vezes a alteração da largura interpré-molares;

- suave verticalização dos dentes inferiores, devido à expansão do arco superior e às alterações nas forças resultantes da oclusão.

A ERM geralmente é realizada com aparelhos que utilizam no mínimo quatro dentes de ancoragem. SCHNEIDMAN; WILSON; ERKIS ${ }^{88}$ em 1990, introduziram um expansor que utilizava apenas os primeiros molares superiores como ancoragem, avaliando as alterações dentárias decorrentes do seu uso, comparando-as com as observadas no Hyrax. A amostra consistiu de 50 pacientes, com idade média de 10 anos, divididos em dois grupos homogêneos de 25 pacientes. As ativações foram realizadas de maneira convencional, até a obtenção de uma sobrecorreção do segmento posterior e o período de contenção foi, em média, de 3 meses. Realizaram-se as análises das alterações dentárias com os modelos de gesso, obtidos nas fases pré-expansão e pós-contenção. Também obtiveram as radiografias oclusais antes e imediatamente após a 
expansão, para a observação da abertura da sutura palatina mediana. Como resultados mais relevantes, citaram :

- não se observou diferença estatisticamente significante entre os dois grupos no aumento das distâncias intermolares superiores e intercaninos inferiores, porém nas distâncias intercaninos superiores e intermolares inferiores pode-se notar grande diferença;

- grandes diferenças nas inclinações dos molares superiores. Inclinação lingual, no grupo que utilizou o expansor com dois dentes de ancoragem e inclinação vestibular, no grupo do Hyrax;

- padrão de abertura da sutura palatina mediana foi semelhante nos dois grupos. Baseados nas conclusões anteriores, indicaram este novo tipo de aparelho nas seguintes situações : 1) durante a dentadura mista, onde apenas dois dentes de ancoragem estão presentes; 2) nos casos com grandes apinhamentos e dentes mal alinhados, dificultando a colocação do Hyrax (bandas); 3) necessidade de maior expansão na região posterior do arco.

Discorrendo sobre os preceitos clínicos e radiográficos da $E R M$, SANTOS PINTO; HENRIQUES ${ }^{82}$, em 1990, destacaram a utilização do disjuntor dentomucossuportado tipo Haas, por possuir uma ancoragem máxima. Preconizaram uma volta completa do parafuso por dia, o que equivale a aproximadamente $0,8 \mathrm{~mm}$ a $1 \mathrm{~mm}$ de expansão. A sobrecorreção de 2 a $3 \mathrm{~mm}$ também deveria ser realizada, para compensar as alterações dentoalveolares e a recidiva. Relataram ainda a possível sintomatologia dolorosa nas regiões das suturas nasomaxilar, frontonasal e zigomaticomaxilar e a importância do controle radiográfico (radiografia oclusal) durante o procedimento de expansão, para a observação do comportamento da sutura palatina mediana, além das principais indicações para este procedimento. 
Descrevendo o tratamento de um paciente do sexo feminino, de sete anos de idade, com má oclusão de Classe II, mordida aberta anterior, mordida cruzada posterior e padrão de crescimento excessivamente vertical, PEARSON $^{77}$, em 1991, comentou sobre a necessidade de aplicação de forças intrusivas nos dentes posteriores para evitar a extrusão, principalmente no procedimento de ERM. Para tanto, indicou o uso de uma mentoneira $12 \mathrm{~h}$ por dia durante todo o tratamento. A expansão foi realizada em duas etapas devido ao grau de atresia do arco superior e a contenção consistiu em um aparelho removível com blocos de acrílico na região posterior (BiteBlock) durante cinco meses. Este aparelho apresentava a função de aplicar forças intrusivas nos dentes posteriores e conseqüentemente auxiliar na correção da mordida aberta anterior. O tratamento prosseguiu com a instalação de aparelhos fixos e da ancoragem extrabucal occipital. Em decorrência da boa cooperação do paciente, o caso, apesar de ser limítrofe para a realização de cirurgia ortognática, obteve sucesso e estabilidade observada após 17 meses.

Devido a poucos estudos concernentes às alterações decorrentes da $E R M$ quando realizada precocemente, ou seja, na fase da dentadura decídua ou no $1^{\circ}$ período transitório da dentadura mista, SILVA FILHO; VILLAS BOAS; CAPELOZZA FILHO ${ }^{97}$, em 1991, realizaram uma avaliação cefalométrica de 30 pacientes (idade média de oito anos), tratados com o expansor tipo Haas modificado. Todos possuíam mordidas cruzadas posteriores esqueléticas e o período ativo variou entre uma e duas semanas. As telerradiografias em norma lateral foram obtidas antes e imediatamente após a expansão, para a análise das alterações ântero-posteriores e verticais das bases apicais e dos molares de ancoragem. Baseados nos resultados, observaram : 
- ausência de alterações no posicionamento ântero-posterior da maxila, ou seja, o ângulo SNA manteve-se constante;

- deslocamento inferior da maxila em todos os casos, provocando um deslocamento para baixo e para trás do plano palatino;

- deslocamento inferior dos molares de ancoragem (extrusão);

- alterações ântero-posteriores na mandíbula, observadas pela diminuição do ângulo SNB e o conseqüiente aumento nos ângulos NAP e ANB, devido à rotação mandibular no sentido horário;

- aumento da altura facial e do ângulo do plano mandibular.

Em 1992, VIAZIS et $\mathrm{al}^{109}$, ilustraram com seis casos clínicos, alguns tipos e aplicações dos aparelhos utilizados na expansão do arco superior. Destacaram dois pacientes com mordida cruzada posterior bilateral e mordida aberta anterior. Utilizaram um disjuntor associado a uma grade palatina no primeiro, devido ao hábito de sucção do polegar, obtendo êxito nesta fase do tratamento. No outro paciente, instalou-se um disjuntor colado aos dentes superiores, com um bloco de resina na região posterior, porém, em conseqüência da má higienização, este teve que ser substituído por um arco em W.

Realizando uma vasta revisão de literatura sobre o expansor com cobertura de acrílico, colado aos dentes superiores, MCNAMARA JÚNIOR; BRUDON $^{66}$, em 1993, observaram que este disjuntor além de aumentar as dimensões transversais da maxila, promove alterações no sentido vertical. O acrílico na região posterior $(3 \mathrm{~mm})$ age como um BiteBlock, inibindo o desenvolvimento vertical dos dentes posteriores, sendo indicado para pacientes com crescimento vertical. Além disto, o levantamento oclusal facilita a $E R M$ e a correção das mordidas cruzadas anteriores. Neste trabalho, ainda descreveram 
todos os procedimentos laboratoriais e clínicos, ou seja, a técnica de confecção, instalação, ativação, contenção e remoção (após cinco meses). Para a remoção do disjuntor, utiliza-se alicates (remoção de bandas ou de braquetes anteriores) e quando necessário brocas em alta-rotação, sendo bastante desconfortável para os pacientes, principalmente durante o $2^{\circ}$ período transitório da dentadura mista, onde se observam extrações dos caninos e molares decíduos. Nota-se uma irritação gengival severa após a remoção, influenciada pelo grau de higienização do paciente, que regride em $72 \mathrm{~h}$. A contenção deve ser utilizada por um período mínimo de um ano, podendo-se optar por uma placa de acrílico no arco superior ou uma barra transpalatina.

Investigando as alterações dentárias (arco superior) decorrentes da $E R M$ em modelos de gesso, obtidos nas fases pré-expansão (fase 1), pós-contenção ativa (3 meses - fase 2) e pós-tratamento ortodôntico corretivo (fase 3), CAVASSAN et $\mathrm{al}^{25}$, em 1993, estudaram uma amostra de 16 pacientes, de ambos os sexos, com idade média de 12 anos e 9 meses, submetidos à expansão com um disjuntor dentomucossuportado e subseqüente tratamento corretivo com a técnica edgewise convencional. Analisaram-se várias medidas, tais como as distâncias intercuspídeas e intercervicais dos caninos, pré-molares e molares, profundidade e largura do palato e a inclinação dos molares de ancoragem. Com relação às alterações transversais observaram um aumento em todas as distâncias intercuspídeas e intercervicais na fase 2, com maior magnitude na região posterior (molares e pré-molares) e ao final do período de observação notou-se uma recidiva inevitável, mas a morfologia do arco superior manteve-se adequada. Outra observação importante foi a alteração significante nas regiões cervical e basal do palato, com um aumento de $19 \%$ e $27,2 \%$ respectivamente, entre a fase 1 e a fase 2, denotando um aumento nas larguras palatinas. Ao final 
do tratamento ortodôntico, observou-se uma recidiva de $8 \%$ ao nível cervical e de apenas 1,3\% no basal. Esta diferença pôde ser explicada pela recidiva dos efeitos ortodônticos da $E R M$ e pelo uso da placa de contenção, tocando o palato, durante 6 meses após a expansão. A profundidade do palato manteve-se inalterada com o tratamento, mas nos molares de ancoragem observou-se uma inclinação vestibular acentuada decorrente da expansão, que foi corrigida durante o tratamento ortodôntico corretivo.

A capacidade dilatadora do parafuso expansor muitas vezes não é suficiente, principalmente nos casos de atresias maxilares severas, causando grandes problemas para o clínico, uma vez que este tem apenas duas alternativas a seguir : 1) aguardar a consolidação dos efeitos ortopédicos (90 dias) para a confecção de um novo aparelho expansor ou 2) dar prosseguimento imediato ao processo de expansão. SILVA FILHO, et $\mathrm{al}^{98}$, em 1994, acreditando que, do ponto de vista biológico, financeiro e de tempo de tratamento, tornar-se-ia mais conveniente não interromper o processo ativo da expansão. Para isto, divulgaram uma alternativa prática no reaproveitamento imediato da capacidade dilatadora do parafuso expansor, composta por quatro passos :

- fixação das duas metades acrílicas do aparelho expansor;

- liberação de um lado do dispositivo central contendo o parafuso;

- desativação completa do parafuso;

- incorporação do dispositivo central ao apoio de resina acrílica.

Em um artigo bastante ilustrativo, MARTINS; ALMEIDA; DAINESI ${ }^{63}$, em 1994, discorreram sobre as principais características relacionadas ao correto diagnóstico e tratamento das mordidas cruzadas posteriores, que deve ser realizado precocemente, uma vez que estas raramente corrigem-se sozinhas. 
Comentaram sobre a etiologia, os aspectos clínicos e as indicações, contraindicações, características, método de ativação, efeitos produzidos e modo de contenção dos aparelhos fixos e removíveis para a expansão lenta ou rápida da maxila. Destacaram a importância do diagnóstico diferencial entre a mordida cruzada posterior dentária e esquelética, o que influencia na escolha da mecanoterapia adequada. Para isto indicaram a avaliação do número de dentes envolvidos, a análise dos modelos de gesso, para a observação da inclinação dos dentes posteriores e o exame radiográfico, com a telerradiografia em norma frontal.

MEMIKOGLU; ISERI; UYSAL ${ }^{69}$, em 1994, avaliaram as alterações dentoesqueléticas da ERM realizada com o expansor colado aos dentes superiores (cobertura de acrílico) e compararam com as alterações decorrentes do disjuntor tipo Haas. Utilizando-se de telerradiografias em norma lateral e frontal, analisaram 29 pacientes, divididos em dois grupos : 1) expansor colado em 20 pacientes e 2) expansor bandado em nove pacientes. Todos estavam na fase de crescimento e possuíam mordidas cruzadas posteriores uni ou bilaterais. Após a digitalização dos pontos cefalométricos de referência e a obtenção das medidas lineares e angulares, observaram :

- correção da mordida cruzada posterior em todos os casos;

- aumento nas larguras nasal inferior, maxilar e intermolares nos dois grupos;

- maior inclinação vestibular dos molares no grupo bandado;

- redução significante da sobremordida no grupo bandado $(-2,5 \mathrm{~mm}) \mathrm{e}$ uma pequena redução no grupo colado $(-1,0 \mathrm{~mm})$. Baseando-se nestes resultados, puderam concluir que o expansor colado apresentou-se como 
uma alternativa viável nos pacientes com mordidas abertas anteriores (sobremordida insuficiente).

Neste mesmo ano, SILVA FILHO et $\mathrm{al}^{99}$, verificaram os efeitos suscitados pela $E R M$ durante a dentadura permanente, com uma amostra de 20 pacientes (idade média de 16 anos e 3 meses), portadores de más oclusões de Classe I, II e III e atresia maxilar, sendo 16 do sexo feminino e quatro do sexo masculino. Todos os pacientes utilizaram o disjuntor tipo Haas (dentomucossuportado) e a análise das alterações foi realizada com as telerradiografias em norma lateral, obtidas antes e imediatamente após a expansão. Analisaram-se quatro conjuntos de medidas separadamente : 1) Alterações ântero-posteriores da maxila : não houve deslocamento sagital (ântero-posterior) do ponto $\mathrm{A}$ ou do ponto ENP em relação à base do crânio, nem alteração no comprimento maxilar. Baseados neste estudo e em outro realizado em pacientes nas fases da dentadura decídua e mista ${ }^{97}$, concluíram que a maxila não se desloca anteriormente, independente da faixa etária ou do estágio de desenvolvimento oclusal; 2) Alterações verticais da maxila : relataram o deslocamento inferior da maxila, o aumento das alturas maxilares, a ausência de rotação do plano palatino e o conseqüente aumento nas alturas faciais total, superior e inferior; 3) Alterações verticais da mandíbula: rotação horária da mandíbula e conseqüentemente um aumento na AFAI e nos ângulos que avaliam o comportamento sagital das bases apicais, ou seja, o NAP e o ANB; 4) Alterações ântero-posteriores e verticais dos molares de ancoragem: não constataram alterações significantes no deslocamento sagital dos molares, porém, no sentido vertical observaram um aumento na distância MV-MV', comprovando o deslocamento vertical destes dentes, juntamente com a maxila. 
Preocupados com os efeitos colaterais decorrentes da ERM, como o deslocamento inferior da maxila, a extrusão e a vestibularização dos dentes de ancoragem e a conseqüente rotação horária da mandíbula, principalmente nos pacientes com tendência a mordida aberta esquelética, altura facial aumentada e convexidade facial acentuada, MAJOURAU; NANDA ${ }^{62}$, em 1994, discorreram sobre os meios para se evitar estes efeitos indesejáveis. Ilustrando com um caso clínico, os autores indicaram a utilização de uma mentoneira com tração alta durante a expansão e por mais 7 a 10 semanas após o término deste procedimento, com uma força de $250 \mathrm{~g}$ de cada lado, se possível 12 a $16 \mathrm{~h} /$ dia. Este método pareceu ser eficiente para se evitar os efeitos colaterais, além de manter e controlar a dimensão vertical.

MAZZIEIRO $^{65}$, em 1994, desenvolveu um estudo com a finalidade de comparar, por meio de telerradiografias em norma frontal, as alterações dentoesqueléticas ocasionadas pela utilização de dois tipos de disjuntores para a $E R M$ e as possíveis diferenças entre eles. A amostra de 41 pacientes, de ambos os sexos, foi distribuída em dois grupos : 1) Grupo I, composto por 20 pacientes que utilizaram o disjuntor tipo Haas; 2) Grupo II, composto por 21 pacientes que utilizaram o aparelho tipo Hyrax. Todos possuíam, ao início do tratamento, idades entre 10 e 16 anos e 2 meses, mordida cruzada posterior uni ou bilateral e a necessidade de ERM para a correção da má oclusão. As radiografias pósteroanteriores foram obtidas nas fases pré-expansão, imediatamente pós-expansão e pós-contenção (3 meses), totalizando 123 telerradiografias. Após a análise de 14 medidas lineares e angulares, para a avaliação das alterações dentárias e esqueléticas com o uso destes dois tipos de aparelhos, concluiu que :

- os dois aparelhos expandiram ortopedicamente a maxila; 
- em relação às alterações esqueléticas, não existiram diferenças estatisticamente significantes entre os aparelhos;

- devido à ausência de recidivas esqueléticas significativas durante o período de três meses de contenção, constatou-se uma estabilidade das expansões;

- ocorreu uma maior abertura da mordida na região anterior com os aparelhos dentomucossuportados, porém, no período de contenção não se observaram diferenças estatisticamente significantes;

- os molares de ancoragem apresentaram comportamento semelhante em resposta às forças de expansão;

- a distância intermolares inferiores aumentou em ambos os grupos, porém sem nenhuma correlação com os tipos de aparelhos empregados.

Estudando 32 pacientes, com as idades variando de 5 a 11 anos (média de oito anos) e tratados com o disjuntor tipo Haas modificado, para a correção da atresia do arco superior, SILVA FILHO; MONTES; TORELLY ${ }^{94}$, em 1995, avaliaram as principais alterações decorrentes desta mecânica, com o auxilio de telerradiografias em norma frontal, obtidas nas fases pré e imediatamente pósexpansão. As ativações foram realizadas duas vezes por dia (2/4 por vez) e estas se prolongaram por uma ou duas semanas. As medidas obtidas não tiveram influência do crescimento e desenvolvimento craniofacial devido ao curto intervalo de tempo entre as tomadas radiográficas. Após a realização do cefalograma e a obtenção das medidas lineares, os resultados demonstraram :

- que a radiografia póstero-anterior é um método excelente para a diferenciação dos efeitos ortopédicos e ortodônticos decorrentes da $E R M$;

- aumento estatisticamente significante nas sete medidas analisadas; 
- abertura de um diastema entre os incisivos centrais superiores $(3 \mathrm{~mm}$ em média), com divergência apical e convergência das coroas, observada pelos valores médios das medidas IUI (distância entre a face mesial das coroas) e IAI (distância entre os ápices radiculares), que foram de 2,9 mm e $3,5 \mathrm{~mm}$, respectivamente. Este fato pôde ser explicado pela ação das fibras transeptais;

- aumento médio de $2,8 \mathrm{~mm}$ na distância intertuber (aumento da região basal posterior);

- aumento médio de 5,4 $\mathrm{mm}$ na distância intermolares, como conseqüência dos efeitos ortodônticos e ortopédicos da expansão;

- abertura da sutura palatina mediana em formato triangular, com a base voltada para a cavidade bucal e centro de rotação próximo a sutura frontomaxilar, confirmando que a resposta esquelética apresentou-se maior próxima do parafuso e decresceu em direção à base do crânio;

- aumento médio de 2,0 mm na largura do terço inferior da cavidade nasal. Se o paciente possuir uma deficiência respiratória, quanto mais anterior e inferior se apresentar o problema, melhor o prognóstico com a ERM.

Com a proposição de investigar as características clínicas e radiográficas da discrepância transversal da maxila e discutir os métodos de diagnóstico e tratamento desta má oclusão em pacientes adultos, BETTS et al ${ }^{14}$, em 1995, relacionaram estes pontos com a estabilidade do tratamento, alertando para a maior dificuldade na abertura da sutura palatina mediana em indivíduos após a fase de crescimento. O correto diagnóstico envolve uma avaliação clínica criteriosa, seguida de uma análise radiográfica, de preferência com a telerradiografia em norma frontal, que se trata de um recurso eficiente e 
confiável na avaliação de assimetrias faciais e de atresias maxilares. Os autores ainda citaram a possibilidade de utilização de tomografias frontais, porém existem algumas desvantagens, como o custo elevado e a maior exposição do paciente aos raios $\mathrm{X}$. Como tratamento das atresias maxilares em pacientes adultos (idade esquelética acima de 15 anos), descreveram uma técnica cirúrgica, ilustrando todos os passos com desenhos e fotografias clínicas.

SPILLANE; MCNAMARA JÚNIOR ${ }^{101}$, neste mesmo ano, analisaram uma amostra de 162 pacientes que estavam no $1^{\circ}$ período transitório ou no período intertransitório da dentadura mista (idade média de 8 anos e 8 meses), submetidos à $E R M$, com o expansor que possui cobertura de acrílico, colado aos dentes superiores. Após a ativação, os aparelhos foram mantidos na cavidade bucal por um período médio de cinco meses e a contenção se prolongou por mais um ano com uma placa removível. Confeccionaram-se modelos de gesso para a observação das alterações dentárias, nas fases pré-expansão, imediatamente pós-expansão, um e dois anos após a expansão e após o período total de observação (erupção dos $1^{\text {os }}$ pré-molares - 2,4 anos). Por ser um estudo longitudinal, o número de pacientes diminuiu consideravelmente até a última observação, com um total de 84 indivíduos. Observaram um aumento médio na distância intermolares superiores de 5,94 mm, mantendo-se estável após um ano de observação (manutenção de 90,5 \% da expansão original) e com uma pequena recidiva após 2,4 anos (manutenção de 80,4 \% da expansão original). Estes dentes demonstraram uma maior movimentação de corpo do que de inclinação. A altura palatina apresentou uma pequena diminuição com o tratamento, retornando aos valores iniciais após um ano. Puderam concluir que as principais alterações decorrentes da $E R M$, como o aumento das dimensões 
transversais do arco superior, mantiveram-se estáveis até o final da dentadura mista.

Preocupados com as recidivas das alterações dentárias conseguidas com a ERM, MOUSSA; O’REILLY; CLOSE ${ }^{74}$, em 1995, avaliaram 55 pacientes, sendo 16 do sexo masculino e 39 do sexo feminino, que foram tratados com o expansor tipo Haas e com a ortodontia corretiva. Estes foram selecionados aleatoriamente da amostra de pacientes da clínica particular de Andrew Haas, tratados entre os anos de 1960 e 1980. Todos os pacientes possuíam modelos de gesso pré-expansão e pós-tratamento. O terceiro modelo foi obtido após um período médio de 10 anos pós-contenção. $\mathrm{O}$ aparelho de contenção superior consistia em uma placa de acrílico, utilizada por dois anos e no arco inferior, uma contenção lingual fixa, de canino à canino, utilizada por seis anos. Avaliaram-se as distâncias intermolares e intercaninos superiores e inferiores e o comprimento e o perímetro de ambos os arcos. Após a análise dos dados, concluíram que :

- após o período final de observação, as distâncias intercaninos superiores e intermolares superiores e inferiores aproximaram-se dos valores observados após o tratamento, ou seja, maiores que os iniciais, mostrando uma certa estabilidade do tratamento;

- a distância intercaninos inferiores, o comprimento e o perímetro do arco apresentaram uma grande recidiva em seus valores após o período de observação, sendo comparáveis aos iniciais.

KAWAKAMI $^{55}$, em 1995, desenvolveu um estudo com a finalidade de comparar, por meio de telerradiografias em norma lateral, as alterações dentoesqueléticas propiciadas pela utilização de dois tipos de disjuntores para a 
ERM e as possíveis diferenças entre os aparelhos. A amostra de 41 pacientes, de ambos os sexos, foi distribuída em dois grupos : 1) Grupo I, composto por 20 pacientes que utilizaram o disjuntor tipo Haas; 2) Grupo II, composto por 21 pacientes que utilizaram o aparelho tipo Hyrax. Todos possuíam, ao início do tratamento, idades entre 10 e 16 anos e 2 meses, mordida cruzada posterior uni ou bilateral e a necessidade de ERM para a correção da má oclusão. As radiografias foram obtidas nas fases pré-expansão, imediatamente pós-expansão e pós-contenção (3 meses), totalizando 123 telerradiografias. Segundo a metodologia empregada e a análise dos resultados, constatou-se que :

- imediatamente após a $E R M$, os dois tipos de aparelho apresentaram resultados semelhantes, sem a ocorrência do deslocamento da maxila para anterior e sem reflexos para o perfil mole;

- deslocamento da maxila para baixo;

- rotação horária da mandíbula, aumentando a altura facial ânteroinferior, porém após a contenção esta voltou a sua posição original;

- durante os três meses de contenção após a expansão, os valores da maioria das medidas cefalométricas tenderam a retornar aos seus valores iniciais;

- apenas as medidas Sperp-A, ANB, NAP, Sperp-Rㅁ e Sperp-C므 apresentaram diferenças estatisticamente significantes na comparação entre os dois aparelhos, principalmente durante a fase de contenção.

Questionando as consequiências a longo prazo da ERM, VELÁSQUEZ; BENITO; BRAVO ${ }^{108}$, em 1996, analisaram 30 pacientes, sendo 22 do sexo feminino e 8 do sexo masculino, com idade média de 12 anos e 1 mês no início do tratamento. Estes foram tratados com o disjuntor tipo Haas e posteriormente com a ortodontia fixa, obtendo-se a documentação ortodôntica ao início e ao 
final do tratamento. O tempo médio de duração do tratamento foi de 3 anos e 1 mês. A análise foi realizada com telerradiografias em norma lateral digitalizadas, para a obtenção dos valores angulares e lineares pré e póstratamento ortodôntico. Concluíram que :

- após três anos, houve ausência de alterações esqueléticas verticais e ântero-posteriores da face, que poderiam ser atribuídas à $E R M$;

- as diferenças estatisticamente significantes após três anos, foram observadas, em decorrência do crescimento e do desenvolvimento craniofacial;

- as alterações esqueléticas clássicas decorrentes da $E R M$, como a rotação da mandíbula no sentido horário e a abertura de mordida na região anterior, não foram evidentes após o tratamento ortodôntico.

DARENDELILER; LORENZON ${ }^{31}$, em 1996, descreveram um expansor colado aos dentes superiores, que produzia forças leves e contínuas (500-800 g), pela ativação de uma mola superelástica .022”x .028" Neo Sentalloy. Devido as suas características de confecção, pôde-se quantificar a expansão desejada, não necessitando de reativações diárias e da cooperação do paciente. Ilustraram o artigo com fotos intrabucais, radiografias oclusais e póstero-anteriores pré e pósexpansão, de três pacientes tratados.

Estudando o comportamento radiográfico dos incisivos centrais superiores após a ERM, SILVA FILHO; PINHEIRO JÚNIOR; CAVASSAN ${ }^{95}$, em 1997, acompanharam longitudinalmente, durante um período de 12 meses após a remoção do disjuntor, 10 crianças, sendo 6 do sexo feminino e 4 do sexo masculino, com idade média de 8 anos e 5 meses, ou seja, durante o estágio da dentadura mista. Realizaram-se radiografias periapicais com a técnica do cone 
longo (paralelismo), para a análise do comportamento radicular e da angulação mesiodistal dos incisivos centrais superiores. Estas foram tomadas antes da expansão, após a retirada do aparelho, após a contenção (6 meses) e após 1 ano da remoção do disjuntor. Puderam observar a abertura característica do diastema entre os incisivos, com divergência apical e convergência das coroas. A angulação média mudou de uma convergência apical de $7,4^{\circ}$, observada no início do tratamento, para uma divergência apical de $2,3^{\circ}$, até a remoção do aparelho. Isto se deve à maior aproximação das coroas dos centrais, estimulada pelas fibras transeptais. O que se observou nas outras fases, foi uma tentativa de retorno à posição original, porém sem alcançá-la, ou seja, mesmo após 12 meses, a angulação interincisivos permaneceu diferente da original. No tocante ao comprimento dos incisivos, puderam concluir que a $E R M$ não causou alterações no processo de rizogênese.

No mesmo ano, ASANZA;CISNEROS; NIEBERG ${ }^{9}$, com o objetivo de avaliar as diferenças entre as alterações dentoesqueléticas decorrentes da ERM realizada com o expansor bandado (Hyrax) e com o colado (cobertura de acrílico), analisaram 14 pacientes de ambos os sexos (8 a 16 anos de idade), com mordida cruzada posterior, utilizando telerradiografias em norma frontal e lateral. As telerradiografias em norma frontal foram obtidas nas fases préexpansão, imediatamente pós-expansão e após três meses de contenção e as em norma lateral, apenas no início do tratamento e no final da contenção. Foram analisadas medidas lineares e angulares, não havendo diferenças significantes na fase pré-expansão. As principais observações foram :

- no grupo colado, o deslocamento inferior da espinha nasal posterior e o deslocamento anterior da maxila foram menores, em comparação ao Hyrax; 
- o Hyrax apresentou um aumento significante na altura facial ânteroinferior (AFAI);

- os dois aparelhos demonstraram magnitudes semelhantes nas inclinações vestibulares nos dentes de ancoragem, apresentando uma recidiva nos meses de contenção, aproximando-se dos valores prétratamento;

- semelhança no padrão de expansão entre os dois grupos analisados, apresentando uma ligeira assimetria, eliminando a hipótese de que a cobertura de acrílico poderia causar expansões mais simétricas;

- inclinações linguais semelhantes dos incisivos superiores. Os resultados sugerem que o aumento na dimensão vertical (AFAI), visto constantemente com o Hyrax, pode ser minimizado ou eliminado com o expansor colado. Com isto, afirmaram que este tipo de aparelho poderia ser utilizado nos pacientes com tendência a mordida aberta anterior e padrão de crescimento excessivamente vertical.

Defendendo a ocorrência de uma abertura mais paralela da maxila e um controle vertical eficiente, MEMIKOGLU; ISERI ${ }^{67}$, em 1997 demonstraram a ERM realizada com um expansor rígido, totalmente de acrílico, colado aos dentes superiores e com blocos de mordida posteriores, em uma paciente de 13 anos de idade, portadora de má oclusão de Classe II, apinhamentos severos no arco superior, mordida cruzada posterior, perfil convexo e tendência de crescimento vertical. Puderam observar uma expansão do arco superior bastante efetiva, com ausência de extrusão e pouca vestibularização dos molares de ancoragem, permitindo assim, um maior controle da dimensão vertical. Como vantagens citaram a facilidade de confecção e instalação, porém este também apresentou algumas desvantagens, como a dificuldade de fonação e 
principalmente de higienização, podendo causar problemas gengivais, que geralmente são restritos ao período em que o aparelho está presente na cavidade bucal.

Na técnica de $E R M$, preconiza-se a sobrecorreção do segmento posterior, ou seja, a obtenção de uma relação topo a topo das cúspides linguais dos $1^{\text {os }}$ molares superiores com as cúspides vestibulares dos $1^{\text {os }}$ molares inferiores. Defendendo esta sobrecorreção e a utilização do expansor com cobertura de acrílico, colado aos dentes superiores, nos pacientes com padrão de crescimento vertical, STEIMAN ${ }^{105}$, em 1997, relatou a dificuldade de visualização da quantidade de expansão obtida com este tipo de aparelho. Para tanto, indicou a colocação de uma pequena fita vermelha sobre as cúspides linguais dos dentes de ancoragem, durante o processo de confecção do aparelho, facilitando a visualização.

CAPELOZZA FILHO; SILVA FILHO ${ }^{22,23}$, em 1997, discorreram sobre as considerações gerais e as aplicações clínicas da ERM. Inicialmente, salientaram a importância do correto diagnóstico da mordida cruzada posterior e, sempre que possível, o tratamento precoce desta má oclusão. Diferenciaram os principais efeitos ortopédicos e ortodônticos decorrentes da $E R M$ e as alterações analisadas nas telerradiografias em norma lateral e frontal. Contestaram o avanço da maxila como resultado da $E R M$, tão propagado na literatura, porém observaram um abaixamento da maxila e dos molares de ancoragem, ocasionando uma rotação para baixo e para trás da mandíbula. Concordando com a literatura pertinente, a mandíbula, ao girar no sentido horário, induz alterações cefalométricas significativas, como o aumento do ângulo do plano mandibular e do eixo "y" de crescimento, bem como da altura 
facial ântero-inferior. Conseqüentemente, observa-se um tênue aumento do trespasse horizontal e dos ângulos do perfil facial (NAP e ANB). Estas alterações decorrentes da $E R M$ são desfavoráveis para os pacientes que apresentam uma tendência de crescimento vertical. Em uma visão frontal, destacou-se a visualização do comportamento dos incisivos centrais superiores, o aumento da cavidade nasal (terço inferior) e da largura da maxila. Descreveram ainda o procedimento de ERM em pacientes após a fase de crescimento, que pode ser realizado com o auxílio da cirurgia ortognática.

Questionando a estabilidade a longo prazo das alterações esqueléticas produzidas pela ERM, CHANG, MCNAMARA JÚNIOR; HERBERGER ${ }^{27}$, em 1997, realizaram um estudo longitudinal em três grupos de pacientes, analisando principalmente o posicionamento ântero-posterior da maxila e a relação deste procedimento com a abertura da mordida na região anterior. O grupo I, foi composto por pacientes submetidos à $E R M$, com o aparelho tipo Haas, e ao tratamento ortodôntico corretivo subseqüente, sem extrações, sendo 7 do sexo masculino e 18 do sexo feminino. O grupo II, foi composto por 25 pacientes, pareados pela idade e pelo sexo ao grupo de ERM, tratados apenas com a ortodontia corretiva (técnica edgewise convencional). O terceiro, constituiu-se no grupo controle, formado por 23 pacientes, sendo 16 do sexo feminino e 7 do sexo masculino. Analisaram-se as telerradiografias em norma lateral (10 medidas) nas fases pré-tratamento, pós-tratamento e após um período médio de cinco anos do final do tratamento, chegando às seguintes conclusões :

- não houve relação entre o grande valor do ângulo do plano mandibular (MPA) observado antes do tratamento, com a maior tendência no aumento deste ângulo com a $E R M .76,5 \%$ dos pacientes que possuíam 
valores altos para esta medida no início do tratamento, demonstraram uma diminuição ao final da observação;

- a ERM utilizada nos casos de más oclusões de Classe I e de Classe II, que necessitavam do aumento transversal do arco superior, não produziu alterações verticais e ântero-posteriores significantes na face, em uma observação a longo prazo.

O padrão de mineralização da sutura palatina mediana após a $E R M$ foi investigado por VARDIMON et al $^{107}$, em 1998, utilizando uma amostra de 10 gatos no grupo experimental e 2 no grupo controle. Este tratamento consistiu em três fases : - fase ativa (25 dias); - fase de contenção (60 dias) e - fase de recidiva (60 dias após a remoção do aparelho). As radiografias oclusais padronizadas foram tomadas periodicamente e analisadas quanto à largura da sutura na região anterior e posterior, densidade ótica da sutura na região anterior e posterior (grau de mineralização) e mensurações das áreas radiolúcidas e radiopacas na região da sutura, nas três fases citadas. Durante a fase ativa, a zona radiolúcida (tecido não mineralizado) aumentou 12 vezes e o aumento da densidade ótica e da largura da sutura foram, respectivamente, $50 \%$ e $15 \%$ maiores na região anterior da sutura do que na posterior. Os padrões das alterações na largura da sutura palatina foram semelhantes às alterações das zonas radiolúcidas. Durante o período de contenção, a zona radiopaca da sutura (tecido mineralizado) aumentou $62 \%$, a zona radiolúcida diminuiu $64 \%$ e a largura da sutura diminuiu $65 \%$, indicando uma reorganização do tecido mineralizado. O decréscimo da densidade ótica (mineralização aumentada) foi 2,5 vezes maior na região posterior da sutura do que na anterior, indicando um padrão de remineralização (fechamento) póstero-anterior, semelhante ao "fechamento de um zíper". Na fase de recidiva, 78 \% dos animais apresentaram 
diminuição na área total da sutura (41\% de recidiva). Baseados nos resultados, indicaram que a contenção na região anterior deveria ser mais longa do que da posterior, para compensar a reconstrução e maturação tardias do tecido duro recentemente depositado.

Demonstrando o tratamento de uma paciente de 10 anos de idade, com má oclusão de Classe I, mordida cruzada posterior unilateral e padrão de crescimento vertical, LÉON et $\mathrm{al}^{59}$, em 1998, comprovaram que o expansor colado com cobertura acrílica, além de ter promovido a abertura da sutura palatina mediana e corrigido satisfatoriamente a atresia maxilar, também possibilitou o controle vertical da maxila e da mandíbula durante o procedimento de expansão. $\mathrm{O}$ aumento nas distâncias intermolares e intercaninos superiores foram, respectivamente, $8 \mathrm{~mm}$ e $4 \mathrm{~mm}$. Os incisivos centrais superiores apresentaram uma inclinação para lingual, enquanto os inferiores inclinaram para vestibular.

Com o propósito de avaliar as alterações dentárias decorrentes da expansão rápida $(E R M)$ e da expansão lenta da maxila $(E L M)$ e suas possíveis diferenças, AKKAYA; LORENZON; ÜÇEM², em 1998, analisaram 24 pacientes portadores de más oclusões de Classe I ou de Classe II e mordida cruzada posterior bilateral. Estes foram divididos em dois grupos : - no Grupo I, utilizaram um expansor tipo Hyrax, com cobertura de acrílico, colado aos dentes superiores para a realização da $E R M$, apresentando pacientes com idade média de 11 anos; - no Grupo II utilizaram o expansor tipo Minne-expander, com cobertura de acrílico, colado aos dentes superiores para a realização da ELM, apresentando pacientes com idade média de 12 anos. Realizaram-se as análises nos modelos de gesso, obtidos nas fases pré-expansão, pós-expansão e pós- 
contenção (3 meses). Quantificaram as distâncias intermolares e intercaninos superiores e inferiores, as distâncias interpré-molares e interincisivos (diastema) superiores e o perímetro do arco superior. Constataram que no Grupo I houve um aumento significante em todas as medidas após a expansão e no período de contenção, ocorreu uma diminuição significante no perímetro do arco superior e nas distâncias intercaninos e interincisivos superiores, além de um aumento nas distâncias intercaninos e intermolares inferiores. No Grupo II, apenas a distância interincisivos não demonstrou aumento significante após a expansão. No período de contenção, os resultados foram semelhantes ao Grupo I. O aumento da distância intercaninos superiores foi maior no Grupo I, porém a distância intermolares foi semelhante. A análise dos resultados demonstrou que o aumento no perímetro do arco podia ser previsto pela multiplicação do valor da expansão posterior (região de pré-molares) pelo fator .065, na ERM, ou por .060 na ELM.

MARTINS; HENRIQUES; VELÁSQUEZ ${ }^{64}$, em 1998, descreveram um aparelho tipo Hyrax modificado (dentossuportado), colado nas faces palatinas dos dentes de ancoragem, que causaria maiores efeitos ortodônticos (inclinação dentoalveolar) em detrimento dos efeitos ortopédicos, sendo indicado para pacientes na fase da dentadura mista, com mordidas cruzadas posteriores e dentes que dificultariam o procedimento convencional de bandagem (coroas curtas ou cônicas e apinhamentos severos). Como vantagens, citaram a facilidade de confecção, instalação, higienização e remoção. Exemplificaram com um caso clínico, demonstrando a efetividade deste aparelho, sendo mais uma alternativa para o tratamento precoce das mordidas cruzadas posteriores. 
Vinte pacientes que necessitavam da $E R M$ e da intrusão dos incisivos superiores, sem o aumento da dimensão vertical, foram estudados por PEARSON; PEARSON ${ }^{78}$, em 1999. Devido à necessidade do grande controle vertical, instalou-se o expansor com cobertura de acrílico, colado aos dentes superiores, associado ao uso da mentoneira (tração vertical). Iniciou-se a intrusão, após o fechamento do diastema entre os incisivos centrais superiores, causado pela expansão, utilizando-se um arco contínuo de intrusão, por um período médio de 4 meses. Avaliaram-se as telerradiografias em norma lateral (17 variáveis) e os modelos de gesso (1 variável) obtidos antes do tratamento e após a remoção do expansor. Notaram que com esta mecânica, se consegue o aumento transversal da maxila $(8 \mathrm{~mm})$, a intrusão dos incisivos superiores (3 $\mathrm{mm}$ ) e a ausência de alterações na altura facial ântero-inferior e no ângulo do plano mandibular.

Com o objetivo de constatar cefalometricamente as alterações dentoesqueléticas provenientes da $E R M$, bem como verificar a estabilidade das mesmas, ALMEIDA; CAPELOZZA FILHO; TRINDADE JÚNIOR ${ }^{4}$, em 1999, avaliaram 15 pacientes leucodermas, de ambos os sexos, na faixa etária de 11 a 17 anos de idade, com atresia maxilar, submetidos à $E R M$ e ao tratamento ortodôntico corretivo. Realizaram-se as avaliações com telerradiografias em norma lateral, tomadas antes da expansão, imediatamente após a expansão, após a remoção do aparelho (três meses de contenção) e um ano após o início do tratamento. Puderam concluir que a ERM introduziu uma série de mudanças que, apesar de insignificantes do ponto de vista estatístico, promoveram importantes alterações no padrão vertical do complexo craniofacial. A maioria dos valores apresentaram tendência à recidiva na observação final. Para exemplificação, citaram o comportamento mandibular, que apresentou uma 
rotação no sentido horário (diminuição do ângulo SNB) devido a uma associação de fatores, como a sobrecorreção do segmento posterior e a inclinação vestibular dos dentes de ancoragem e correspondentes processos alveolares. Os ângulos do perfil facial ANB e NAP apresentaram um aumento, em resposta a esta rotação mandibular, uma vez que o ponto A (maxila) permaneceu estável no sentido ântero-posterior. Estes medidas apresentaram uma tendência de retorno aos seus valores originais ao longo do período de observação.

Discutindo a menor inclinação vestibular dos dentes de ancoragem durante a $E R M$ realizada com o expansor colado aos dentes superiores, devido à maior rigidez do aparelho, relatada na literatura, MEMIKOGLU; ISERI ${ }^{68}$, em 1999, analisaram as principais alterações transversais dentoesqueléticas decorrentes do tratamento com este tipo de aparelho durante a fase de crescimento. A amostra constituiu-se de 14 pacientes, sendo 11 do sexo feminino e 3 do sexo masculino, com idade média de 12 anos e 8 meses ao início do tratamento e portadores de mordidas cruzadas posteriores bilaterais. Estes foram tratados com a $E R M$ e o aparelho fixo, em um período médio de 3 anos e 8 meses. Obtiveram as telerradiografias em norma frontal e os modelos de gesso ao início do tratamento (fase 1), após a fase de contenção (fase 2 - 6 meses) e ao final do tratamento ortodôntico corretivo (fase 3), analisando sete variáveis lineares e angulares nas radiografias e duas nos modelos de gesso. Entre a fase 1 e a fase 2, observaram aumentos significantes nas larguras basal da maxila, inferior da cavidade nasal, intercaninos e intermolares superiores. Entre a fase 2 e a fase 3, notaram uma constância em todas as medidas, com exceção da distância intercaninos superiores, apresentando uma suave recidiva, porém na comparação entre as fases 1 e 3, todas as mensurações apresentaram 
aumentos significantes. Esta estabilidade foi mais relacionada a atuação do aparelho fixo do que a qualquer característica do tipo de aparelho de expansão. Puderam concluir que as alterações dentoesqueléticas provocadas pela ERM, realizada com o expansor colado, mantiveram-se estáveis até o final da terapia com a aparelhagem fixa.

O primeiro relato sobre a $E R M$ descrito por Angell, em 1860, foi desacreditado e contestado, principalmente por argumentos de Mc Quillen. Estes argumentos foram considerados irrelevantes após uma análise dos documentos originais realizada por TIMMS ${ }^{106}$, em 1999, que indicou que o histórico do caso concordou com as observações atuais, mantendo a tese de Angell. Além disto, descreveu mais alguns princípios que deveriam ser aceitos neste trabalho sem precedentes : 1) a importância dos primeiros molares no desenvolvimento oclusal e 2) a utilização de uma placa de contenção.

Preocupados com as alterações verticais oriundas da ERM, como a abertura de mordida na região anterior, desfavoráveis para alguns pacientes, REED; GHOSH; NANDA ${ }^{79}$, em 1999, realizaram um estudo comparativo entre 38 pacientes (idade média de 12 anos e 9 meses) que utilizaram o expansor bandado tipo Hyrax e 55 pacientes (idade média de 13 anos e 3 meses) que utilizaram o expansor colado. Após o período ativo, os aparelhos bandados e colados permaneceram na cavidade bucal, respectivamente, por um período médio de contenção de 4,9 meses e 5,6 meses, e posteriormente todos os pacientes receberam o tratamento ortodôntico corretivo (técnica edgewise convencional). Para a análise, obtiveram telerradiografias em norma lateral e modelos de gesso ao início e ao final do tratamento. Os resultados demonstraram que: 
- o aumento da distância intermolares superiores foi duas vezes maior no grupo colado;

- as alterações verticais foram maiores no grupo bandado, com valores mais altos para as medidas FMA e SNGoGn;

- as medidas lineares que avaliam as alterações verticais da maxila foram semelhantes nos dois grupos;

- não houve correlação entre o tempo de permanência do aparelho com cobertura de acrílico na cavidade bucal (tempo de contenção variou de 4 a 7 meses) e o maior controle vertical;

- a maioria das medidas analisadas, apresentaram diferenças entre os grupos menores do que $1^{\circ}$ ou $1 \mathrm{~mm}$, ou seja, clinicamente insignificantes, portanto, nenhum aparelho demonstrou superioridade quando comparados após a finalização do tratamento ortodôntico corretivo.

Em um estudo comparativo, AKKAYA; LORENZON; ÜÇEM ${ }^{3}$, neste mesmo ano, avaliaram as principais alterações verticais e sagitais suscitadas pela $E R M$ e pela $E L M$, com aparelhos colados aos dentes superiores e com cobertura de acrílico na região posterior. Os pacientes apresentavam más oclusões de Classe I ou de Classe II, com mordida cruzada posterior bilateral, sendo divididos em dois grupos de 12 indivíduos cada. O Grupo I, com idade média de 11 anos ao início do tratamento e composto por 5 pacientes do sexo feminino e 6 do sexo masculino foram tratados com a $E R M$, utilizando-se o parafuso tipo Hyrax e blocos de mordida posteriores (espessura de $1 \mathrm{~mm}$ ). O Grupo II apresentou a mesma quantidade de pacientes do Grupo I, com idade média de 12 anos, tratados com o aparelho tipo Minne-expander associado a blocos de mordida posteriores, para a ELM. As telerradiografias em norma lateral foram 
obtidas no início e no final da expansão e no final do período de contenção (3 meses). Os resultados mais relevantes foram :

- deslocamento anterior da maxila nos dois grupos, avaliado pelo ângulo SNA, porém esta medida apresentou uma tendência de retorno aos seus valores iniciais durante o período de contenção;

- rotação horária da mandíbula, com aumento no ângulo do plano mandibular e verticalização dos incisivos superiores, observadas apenas no Grupo I;

- aumento do ângulo interincisivos e do trespasse horizontal em ambos os grupos;

- aumento significante da sobremordida $(1,14 \mathrm{~mm})$, durante o período de contenção, no Grupo I, devido ao retorno da mandíbula à sua posição original (rotação anti-horária) e pela inclinação lingual dos incisivos superiores;

- ausência de diferenças significantes para as mudanças finais entre os grupos.

Comparando as alterações dentoesqueléticas da ERM realizada com dois tipos de disjuntores, FALTIN JÚNIOR; MOSCATIELLO; BARROS ${ }^{35}$, em 1999 avaliaram cefalometricamente dois grupos de pacientes. A amostra constou de 32 telerradiografias em norma lateral, obtidas de 16 pacientes (fases pré e pósexpansão) leucodermas, de ambos os sexos e com mordida cruzada posterior bilateral. Oito utilizaram o expansor tipo Haas e os outros, utilizaram o expansor preconizado pelo autor. Este consiste em um aparelho misto ou semifixo, apresentando uma parte removível, composta por uma porção de acrílico que cobre o palato e o parafuso expansor, que pode ser removida para a higienização e eventuais desgastes no acrílico. O componente fixo é constituído por duas 
capas de acrílico que formam um plano de mordida posterior. A porção removível se adapta perfeitamente à estes blocos de resina posteriores. Realizouse a análise cefalométrica de Ricketts, os testes estatísticos e a análise comparativa dos dados, podendo chegar à conclusão de que o aparelho preconizado por FALTIN JÚNIOR ${ }^{35}$ apresentou menores alterações verticais (maior controle vertical), sendo indicado para pacientes com tendência à mordida aberta anterior e com o padrão de crescimento excessivamente vertical.

SMITH; ENGLISH ${ }^{100}$, em 1999, relataram o tratamento de um paciente de 14 anos de idade, do sexo masculino, com perfil esquelético de Classe III, retrusão e atresia maxilar, que foi encaminhado para uma avaliação cirúrgica, porém o desejo de se evitar o procedimento cirúrgico, os guiou para um tratamento ortopédico-ortodôntico. A má oclusão foi corrigida com um expansor colado ao arco superior $(E R M)$, seguida da tração reversa da maxila e subseqüente tratamento ortodôntico sem extrações. Os ganchos para a tração reversa da maxila foram colocados na região dos caninos, durante a confecção do expansor colado. Obtiveram uma relação de molares e de caninos Classe I e melhora no perfil facial.

CARREIRA $^{24}$, em 1999, realizou um estudo cefalométrico objetivando inspecionar, longitudinalmente, a influência da utilização de expansores com bandas (Haas e Hyrax) sobre o comportamento da face, no plano sagital. A amostra consistiu de 25 pacientes apresentando más oclusões de Classe I e II de Angle com mordida cruzada posterior uni ou bilateral, tratados com o procedimento de expansão rápida da maxila previamente à mecanoterapia com a técnica edgewise simplificada. Esta amostra foi comparada a um grupo de 25 pacientes Classe I e II que receberam tratamento corretivo sem expansão prévia, 
e a um grupo controle de 26 jovens, pareados por sexo e idade com os pacientes dos demais grupos. Utilizaram-se telerradiografias em norma lateral tomadas ao início, término e três anos após o tratamento corretivo completo. Os resultados confirmaram que, a longo prazo, a expansão rápida da maxila: não apresentou influência sobre a posição ântero-posterior das bases ósseas apicais; não alterou o padrão de crescimento facial e as dimensões verticais da face; não influiu significantemente no posicionamento vertical dos primeiros molares, na inclinação vestibulolingual dos incisivos superiores e inferiores, e nos trespasses horizontal e vertical; e conseqüentemente, não introduziu alterações no perfil tegumentar. 


\section{PROPOSIÇÃO}




\section{PROPOSIÇÃO}

Em uma amostra constituída por jovens de ambos os sexos, com mordidas cruzadas posteriores, uni ou bilaterais, submetidos à expansão rápida da maxila $(E R M)$, por meio de expansores fixos tipo Haas, Hyrax ou expansor colado aos dentes superiores, objetivou-se, com auxílio de telerradiografias em norma frontal, observar as possíveis diferenças entre os três aparelhos e :

3.1 - analisar as alterações esqueléticas decorrentes da expansão rápida da maxila, imediatamente após a expansão e as mudanças ocorridas durante e após o período de contenção ativa com o próprio aparelho;

3.2 - verificar as alterações dentárias decorrentes da expansão rápida da maxila, como o aumento da distância intermolares superiores e inferiores, a resposta dos incisivos centrais superiores $\mathrm{e}$ as mudanças angulares destes dentes, imediatamente após a expansão e as alterações ocorridas durante e após o período de três meses de contenção com o próprio aparelho;

3.3 - avaliar e comparar as alterações verticais, provocadas pelos três tipos de aparelhos para a expansão rápida da maxila, durante este procedimento e após o período de contenção. 
4. MATERIAL E MÉTODOS 


\section{MATERIAL E MÉTODOS}

\section{1) MATERIAL}

Os grupos de pacientes que utilizaram os expansores dentomucossuportados (Haas modificado) e dentossuportados (Hyrax modificado) utilizados nesta pesquisa, foram alvo de comparações e estudos, realizados por MAZZIEIRO ${ }^{65}$, em 1994, por meio de telerradiografias em norma frontal. Esta amostra foi obtida a partir do exame de 500 pacientes que se inscreveram para receber tratamento ortodôntico no curso de Especialização em Ortodontia da Faculdade de Odontologia de Bauru - Universidade de São Paulo (FOB-USP). Após a triagem, foram selecionados 41 pacientes, que apresentavam as seguintes características:

a) leucodermas;

b) idade no início do tratamento, entre 10 anos a 16 anos e 2 meses;

c) mordida cruzada posterior uni ou bilateral;

d) indicação de expansão rápida da maxila para a correção da má oclusão.

Partindo deste número de pacientes, a amostra foi dividida em dois grupos distintos, de acordo com o aparelho utilizado para o procedimento de expansão rápida da maxila. No Grupo $I,(n=20)$ instalaram-se os aparelhos dentomucossuportados (Haas modificado), e no Grupo II $(n=21)$, os aparelhos dentossuportados (Hyrax modificado).

O material para a análise e para a comparação constou de três telerradiografias em norma frontal (póstero-anterior), de cada paciente selecionado, realizadas no início do tratamento (pré-expansão), imediatamente 
após a expansão rápida e após três meses de contenção com o próprio aparelho, totalizando 123 radiografias.

Obteve-se a amostra de pacientes que utilizaram o expansor com cobertura de acrílico, colado aos dentes superiores (Grupo III), a partir de uma triagem realizada no Departamento de Ortodontia da Faculdade de Odontologia de Bauru e nas Escolas Estaduais da cidade de Bauru. Foram selecionados 22 pacientes de ambos os sexos, que preencheram os mesmos requisitos descritos anteriormente, com exceção da idade ao início do tratamento, que para este grupo variou de 9 anos e 9 meses a 15 anos e 5 meses.

Todos os pacientes do Grupo III $(\mathrm{n}=22)$ foram tratados pelos alunos do curso de Especialização da FOB-USP, seguindo uma padronização dos procedimentos de instalação, ativação, contenção e remoção do expansor com cobertura acrílica, colado aos dentes superiores. Este aparelho foi utilizado como parte inicial do tratamento e durante todo o período de contenção ativa (3 meses) não houve a instalação de nenhum outro aparelho ortodôntico ou ortopédico no arco superior ou inferior.

Estes também foram radiografados, obtendo-se assim três telerradiografias em norma frontal de cada paciente selecionado, realizadas no início do tratamento (pré-expansão), imediatamente após a expansão desejada (pós-expansão) e após três meses de contenção com o próprio aparelho (póscontenção), totalizando uma amostra de 66 radiografias. Portanto, a amostra total foi composta por 189 radiografias. Como o tempo entre as três tomadas radiográficas foi relativamente curto, não se considerou nenhuma influência do crescimento e desenvolvimento craniofacial nas medidas obtidas. 
Em resumo, os pacientes foram divididos em três grupos, de acordo com o tipo de aparelho utilizado no procedimento de expansão rápida:

- GRUPO I - composto por 20 pacientes, sendo 12 do sexo feminino e 8 do masculino, que utilizaram o expansor dentomucossuportado (Haas modificado). Os pacientes apresentavam uma idade média de 13 anos e 5 meses na época da instalação do aparelho.

- GRUPO II - composto por 21 pacientes, sendo 14 do sexo feminino e 7 do masculino, que utilizaram o expansor dentossuportado (Hyrax modificado). Os pacientes apresentavam uma idade média de 12 anos e 10 meses na época da instalação do aparelho.

- GRUPO III - composto por 22 pacientes, sendo 14 do sexo feminino e 8 do masculino, que utilizaram o expansor dentossuportado, com cobertura de acrílico, colado aos dentes superiores. Os pacientes apresentavam uma idade média de 12 anos e 5 meses na época da instalação do aparelho.

As Tabelas 4.1, 4.2 e 4.3 apresentam a distribuição da amostra segundo a idade, sexo e tipo de aparelho utilizado. 
TABELA 4.1 - Distribuição do Grupo I (Haas modificado) segundo idade e sexo.

IDADE

FREQÜÊNCIA /SEXO

MASCULINO

FEMININO

\begin{tabular}{lll}
\hline $10--11$ & 1 & 3 \\
$11---12$ & 1 & 0 \\
$12---13$ & 2 & 4 \\
$13---14$ & 1 & 2 \\
$14--15$ & 1 & 2 \\
$15--16$ & 0 & 0 \\
$16--17$ & 2 & 1 \\
\hline TOTAL & 8 & 12 \\
\hline
\end{tabular}

TABELA 4.2 - Distribuição do Grupo II (Hyrax modificado) segundo idade e sexo.

IDADE

FREQÜÊNCIA /SEXO

MASCULINO

FEMININO

\begin{tabular}{lll}
\hline $10--11$ & 0 & 1 \\
$11---12$ & 0 & 6 \\
$12---13$ & 5 & 0 \\
$13---14$ & 2 & 2 \\
$14--15$ & 0 & 5 \\
$15--16$ & 0 & 0 \\
$16--17$ & 0 & 0 \\
\hline TOTAL & 7 & 14 \\
\hline
\end{tabular}


TABELA 4.3 - Distribuição do Grupo III (Expansor Colado) segundo idade e sexo.

IDADE

FREQÜÊNCIA /SEXO

MASCULINO

FEMININO

\begin{tabular}{ccc}
\hline 9 ---10 & 0 & 1 \\
$10--11$ & 0 & 4 \\
$11---12$ & 1 & 1 \\
12 --- 13 & 2 & 2 \\
$13--14$ & 4 & 3 \\
$14--15$ & 1 & 2 \\
$15--16$ & 0 & 1 \\
\hline TOTAL & 8 & 14 \\
\hline
\end{tabular}




\section{2) MÉTODOS}

\subsection{1) MÉTODO DE CONFECÇÃO DOS APARELHOS}

A confecção detalhada dos aparelhos do Grupo I (Haas) e do Grupo II (Hyrax) foram descritas por MAZZIEIRO ${ }^{65}$, em 1994.

No Grupo III (expansor com cobertura de acrílico, colado aos dentes superiores), foram necessários dois modelos de gesso do arco superior para a construção dos aparelhos. No primeiro, realizou-se a confecção da estrutura metálica (fio $0,9 \mathrm{~mm}$ ), a adaptação do parafuso expansor e os procedimentos de soldagem (Figura 4.1). O fio que contornou os dentes de ancoragem, envolveu a face vestibular e a face palatina destes elementos dentários (Figuras 4.2 e 4.3 ).

Utilizou-se o segundo modelo para a colocação da cobertura de acrílico, de 2 a $3 \mathrm{~mm}$ de espessura ${ }^{66,83}$ (Figura 4.6). Indicou-se os desgastes no modelo para uma perfeita adaptação da resina nas margens gengivais dos dentes envolvidos, aumentando a retenção do aparelho na cavidade bucal. Após a polimerização total da resina realizou-se o acabamento, ou seja, a remoção dos excessos de material e o polimento do aparelho (Figura 4.4).

Os aparelhos foram confeccionados no laboratório da Disciplina de Ortodontia da Faculdade de Odontologia de Bauru, pelo TPD Luiz Sérgio Vieira, que utilizou parafusos expansores com capacidade para $7 \mathrm{~mm}$ de expansão (DENTAURUM 600-010). As Figuras 4.5, 4.6, 4.7 e 4.8 ilustram os três tipos de aparelhos utilizados nesta pesquisa. 


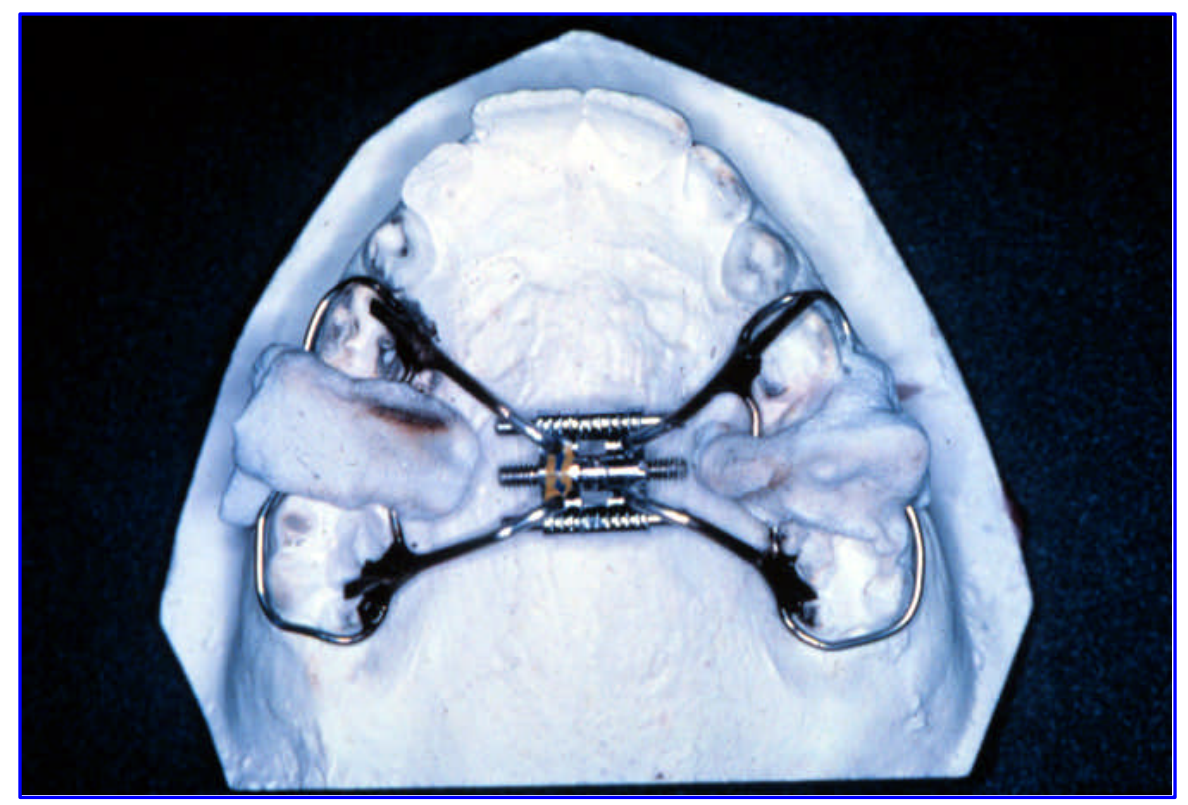

FIGURA 4.1 : Confecção do expansor colado - estrutura metálica, adaptação do parafuso e soldagem no $1^{\circ}$ modelo.

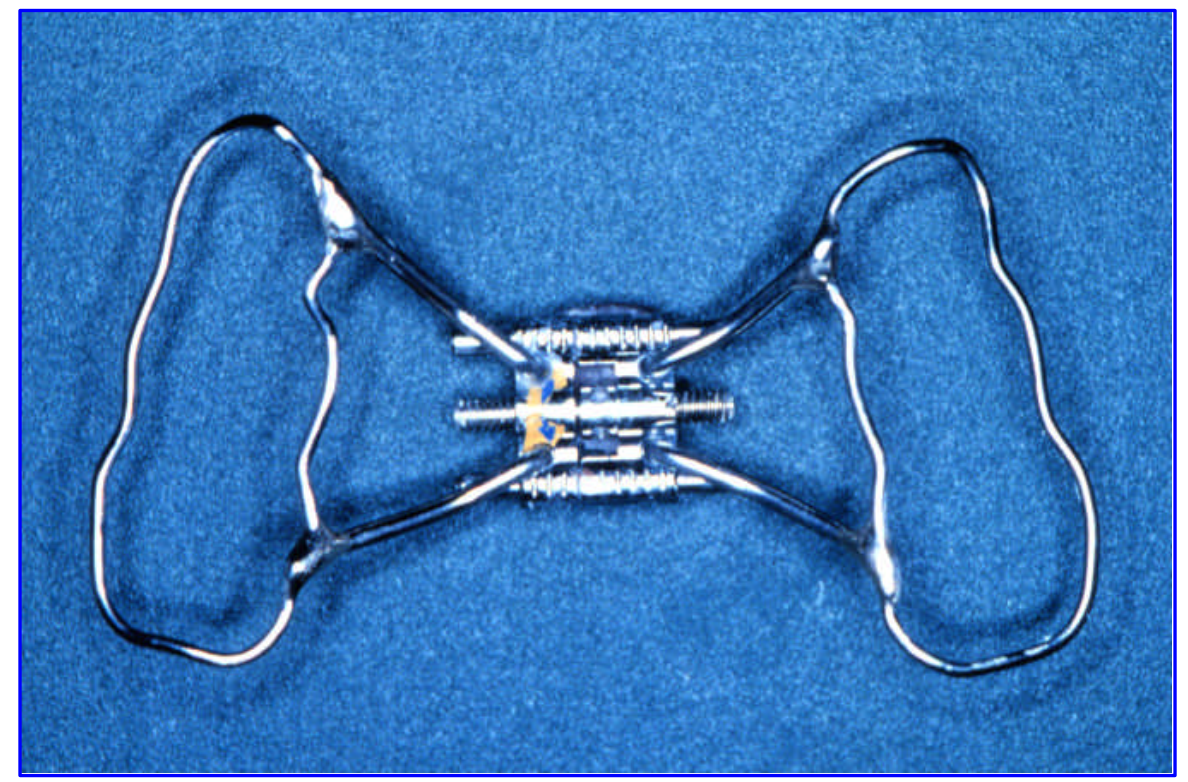

FIGURA 4.2 : Confecção do expansor colado - após o polimento dos locais de solda. 


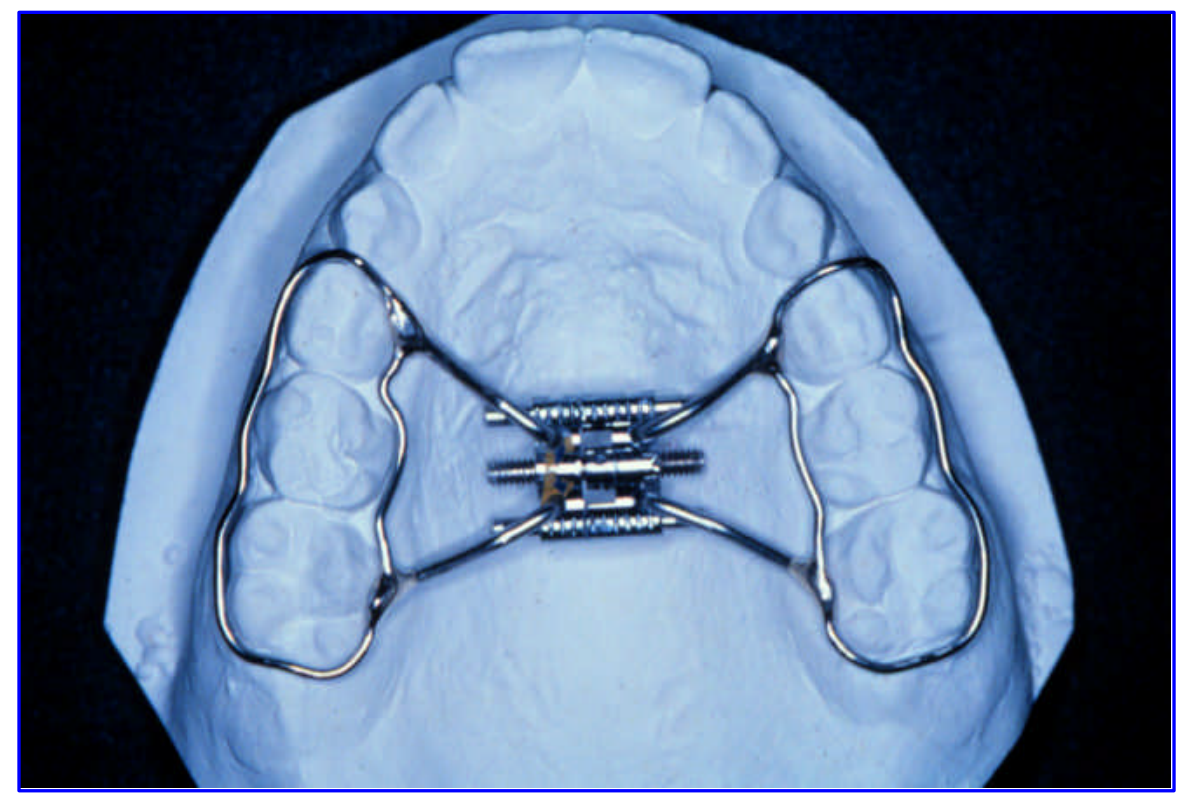

FIGURA 4.3 : Confecção do expansor colado - estrutura metálica (fio $0,9 \mathrm{~mm}$ ), envolvendo as faces vestibulares e linguais dos dentes de ancoragem no $1^{\circ}$ modelo.

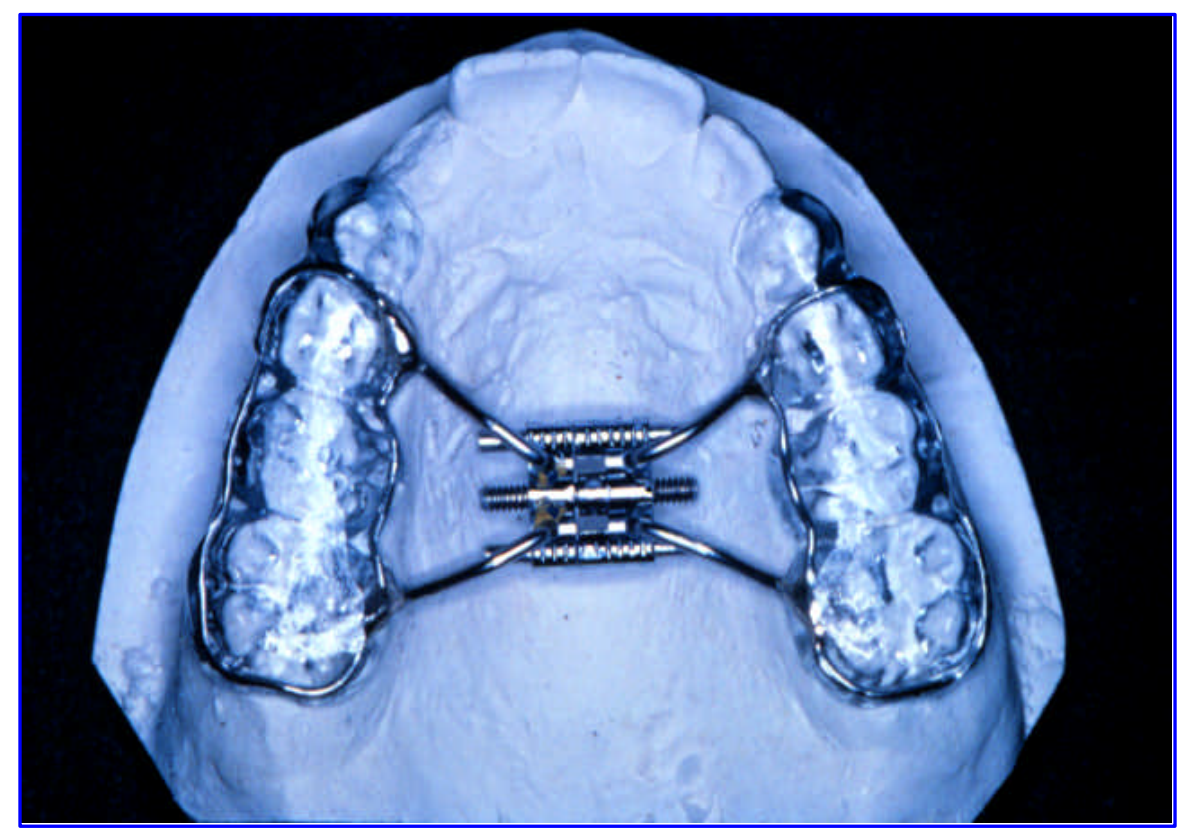

FIGURA 4.4 : Confecção do expansor colado - aparelho acrilizado e polido. 


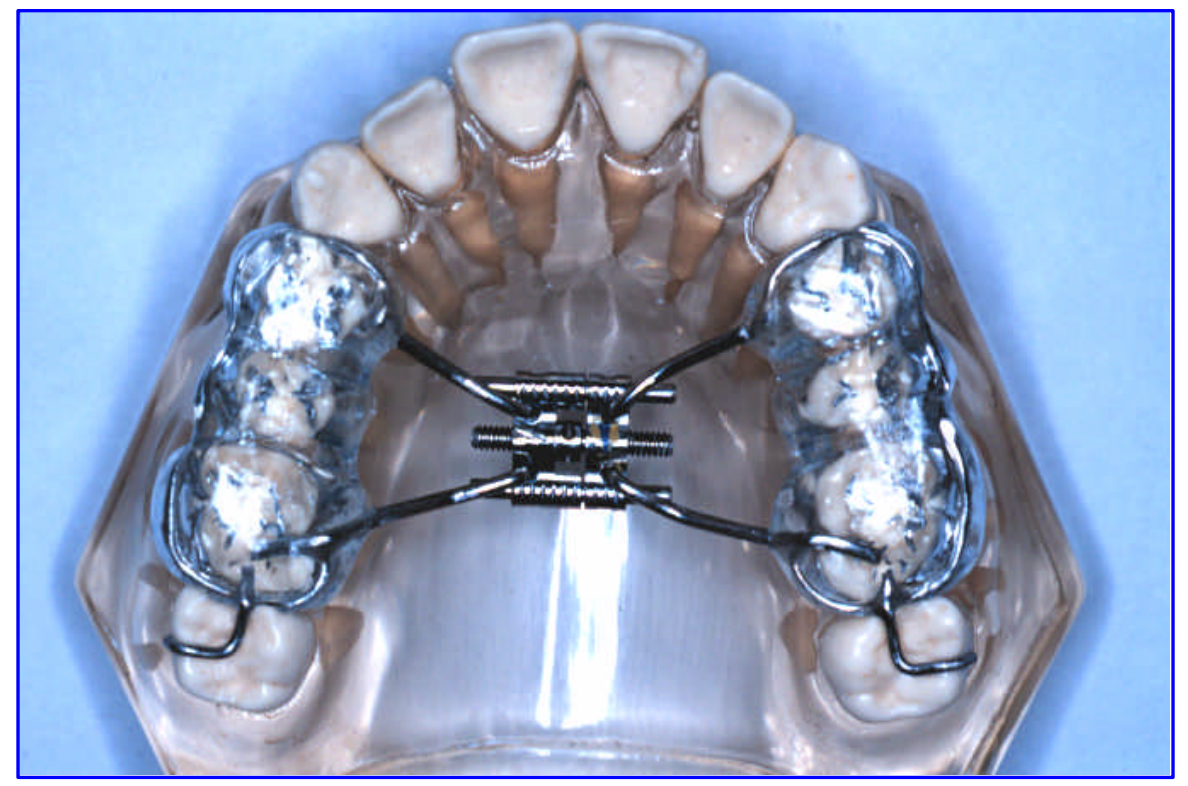

FIGURA 4.5 : Expansor colado - Grupo III.

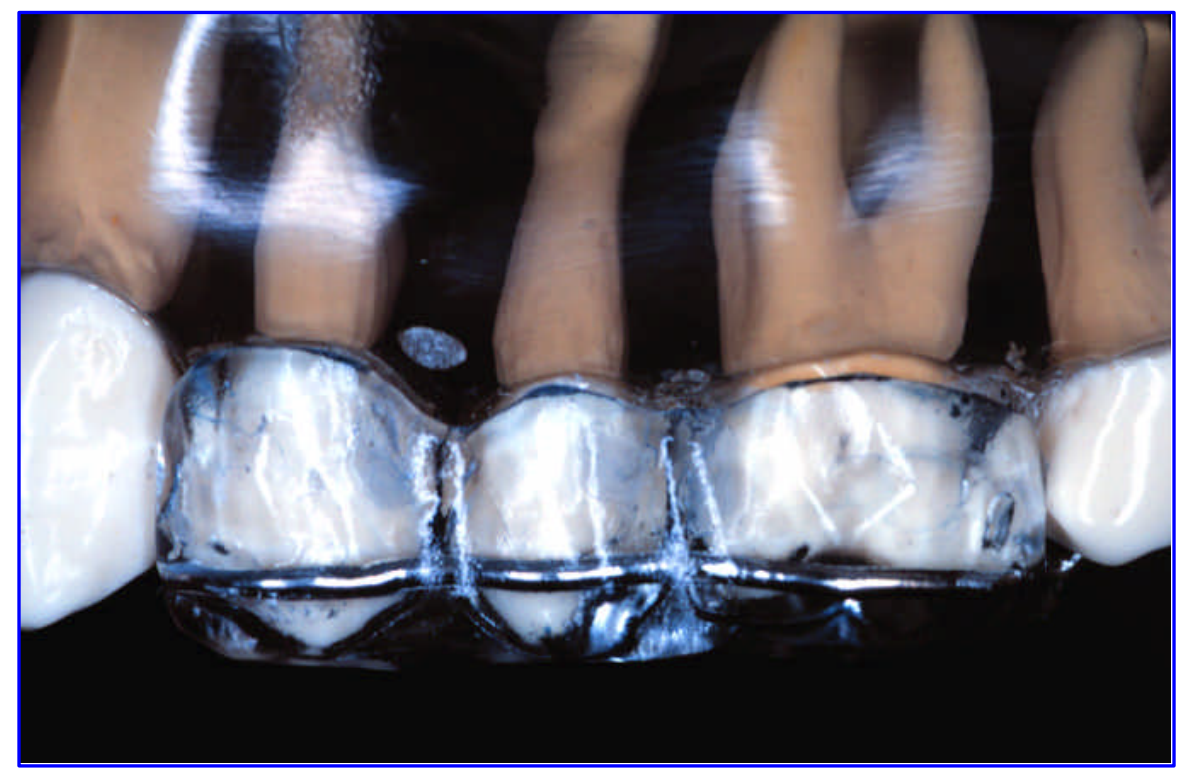

FIGURA 4.6 : Expansor colado - cobertura de acrílico dos dentes de ancoragem. 


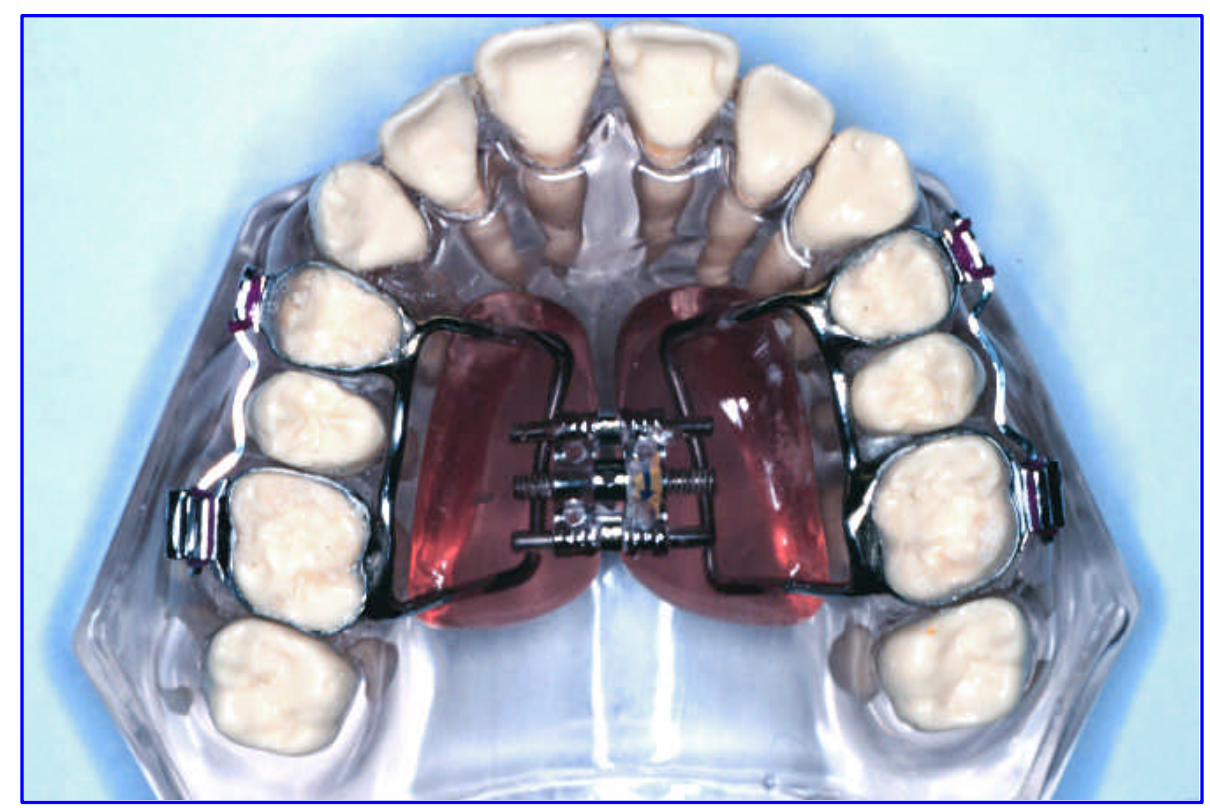

FIGURA 4.7 : Expansor tipo Haas modificado - Grupo I.

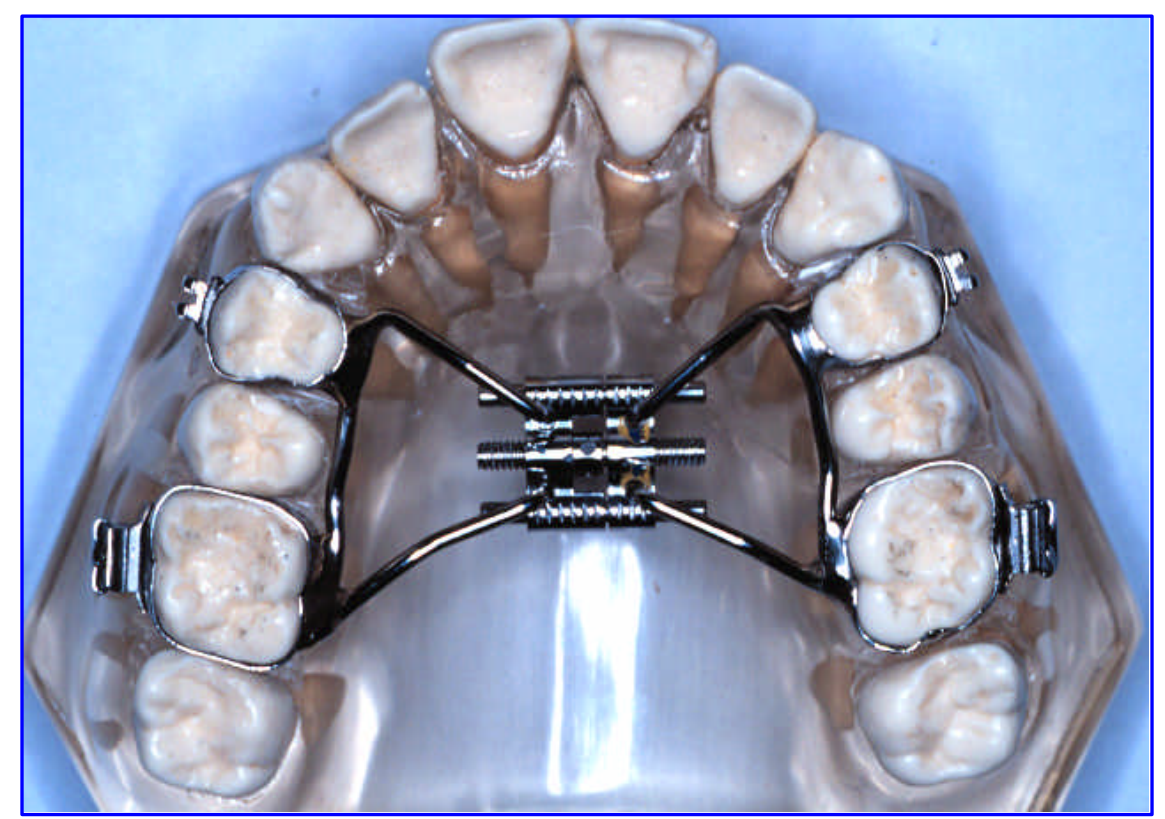

FIGURA 4.8 : Expansor tipo Hyrax modificado - Grupo II. 


\subsection{2) INSTALAÇÃO E ATIVAÇÃO DOS APARELHOS}

Nos Grupos I e II, antes da cimentação dos aparelhos com cimento de fosfato de zinco ou ionômero de vidro, realizou-se uma readaptação das bandas aos dentes de suporte, como descrito por MAZZIEIRO ${ }^{65}$.

No Grupo III, também testou-se o aparelho em posição, com o objetivo de observar a sua adaptação e os contatos da resina com os dentes inferiores, devendo existir uma equilíbrio entre estes, ou seja, a manutenção de contatos bilaterais iguais ${ }^{9,66,83}$.Com o auxílio de um papel carbono, durante a oclusão, verificou-se estes pontos, desgastando-os posteriormente, com a finalidade de evitar contatos prematuros e um possível deslocamento indesejável do aparelho durante o tratamento.

Após esta verificação, realizou-se uma profilaxia prévia para a limpeza da superfície do esmalte dos dentes englobados pelos aparelhos, com uma taça de borracha, pedra pomes e água em baixa rotação. Removeu-se todo o resíduo com um jato de água/ar em abundância, não permitindo assim que qualquer remanescente de pedra pomes permanecesse aderido ao esmalte. Com roletes de algodão, fez-se o isolamento relativo do campo e em seguida a secagem total dos dentes.

Os aparelhos do Grupo III foram cimentados com dois tipos de cimento de ionômero de vidro, manipulados de acordo com as orientações dos seus respectivos fabricantes. Nos nove primeiros pacientes utilizou-se o cimento de ionômero de vidro, autopolimerizável, Ketac Cem (DFL), que apresentou uma baixa resistência, demonstrada pela queda de oito aparelhos ao final da fase de expansão ou durante a fase de contenção. Nestes oito pacientes e nos outros 13 , realizou-se a cimentação com o cimento ionomérico Fuji ORTHO LC (GC Corporation, Tokyo, Japan), que demonstrou uma resistência superior, não se observando nenhum problema relacionado às quedas e à perda de estabilidade 
dos aparelhos. Em alguns casos, este cimento exibiu uma retenção excessiva, causando um certo desconforto para o paciente na hora da remoção do aparelho, sendo desnecessária a utilização do ataque ácido durante o procedimento de instalação, na tentativa de aumentar ainda mais a sua retenção.

Iniciou-se a ativação $48 \mathrm{~h}$ após a cimentação, para que o cimento pudesse adquirir sua resistência máxima, possibilitando também um período de adaptação ao paciente. Nos três grupos ${ }^{65}$, ativou-se o parafuso expansor $2 / 4$ de volta, sendo 1/4 realizado pelo profissional e 1/4 pelo acompanhante do paciente (pais ou responsável), sob supervisão do ortodontista. Nesta mesma consulta, independente do tipo de aparelho utilizado, elucidou-se sobre os efeitos do aparelho, os métodos de higienização, os cuidados a serem tomados e a maneira correta das ativações. Nos dias subseqüentes, estas foram realizadas duas vezes ao dia, sendo $2 / 4$ pela manhã e $2 / 4$ a noite, ou seja, uma volta completa do parafuso $^{55,65}$. Cada paciente apresentou uma variação individual e um grau diferente de atresia do arco superior, tornando inviável qualquer tipo de padronização no tempo de ativação. Considerou-se satisfatória a expansão quando se observaram os contatos diretos das cúspides palatinas dos dentes póstero-superiores com as cúspides vestibulares dos póstero-inferiores, alcançando uma sobrecorreção de 2 a $3 \mathrm{~mm}^{45,71,82,90}$. A higienização procedeu-se de maneira convencional (escovação - limpeza mecânica), e como método auxiliar, indicou-se anti-sépticos bucais para bochechos.

Após o término do período de ativação, o aparelho foi mantido como contenção ativa durante três meses, período em que ocorreu a neoformação óssea na sutura palatina mediana, observada com o auxilio de radiografias oclusais e a dissipação das forças residuais acumuladas. 


\subsection{3) MÉTODO RADIOGRÁFICO}

As telerradiografias utilizadas foram obtidas em norma frontal (radiografia póstero-anterior), seguindo as normas e recomendações do Departamento de Radiologia da Faculdade de Odontologia de Bauru Universidade de São Paulo. Os aparelhos descritos neste capítulo também pertencem a este Departamento.

As tomadas radiográficas dos Grupos I e II foram realizadas em um aparelho de raios $\mathrm{X}$ da marca SIEMENS, modelo NANOMOBIL 2, regulado para uma exposição de $75 \mathrm{KVp}, 15 \mathrm{~mA}$, a uma distância focal de 1,56 m e com duração média de 1,5 segundos. Padronizou-se a posição da cabeça no cefalostato, segundo as normas descritas por RICKETTS ${ }^{80}$, de modo que ao introduzir as olivas metálicas nos seus respectivos meatos, o paciente permanecesse de frente para o chassi e que houvesse apenas um leve toque no seu nariz. Além disto, numa visão lateral, observou-se o paralelismo do Plano de Frankfurt em relação ao solo, em ambos os lados. Orientou-se os pacientes que permanecessem com os lábios em posição de repouso e em máxima intercuspidação habitual. Foram utilizados filmes da marca KODAK "X-OMAT XK1", de tamanho 18 X $24 \mathrm{~cm}$, sem ecrans intensificadores. Apesar deste tipo de aparelho apresentar um fator de magnificação (efeito de ampliação) da imagem radiográfica de $6 \%^{11}$, não se realizou nenhum tipo de correção dos valores obtidos para posterior análise ${ }^{65}$.

Obteve-se as telerradiografias em norma frontal do Grupo III em um aparelho de raios X ROTOGRAPH PLUS, regulado para uma exposição de 80 $\mathrm{KVp}, 10$ mA, com uma distância focal de 1,60 m e tempo de exposição de 1,3 segundos. O posicionamento da cabeça do paciente foi padronizado pelo cefalostato, observando-se sempre o paralelismo do Plano de Frankfurt em relação ao solo de ambos os lados. Orientou-se os pacientes que ficassem com 
os lábios em posição de repouso e em máxima intercuspidação habitual. Utilizou-se filmes da marca KODAK "T-MAT G/RA", de tamanho 20 X $25 \mathrm{~cm}$, com ecrans intensificadores da marca KODAK ("LAREX REGULAR SCREENS"). Este aparelho apresentava um fator de ampliação das imagens radiográficas com valor médio de 9,2 \% ${ }^{89}$. A correção desta magnificação, foi realizada aplicando-se o fator multiplicador 106/109,2 (0,9706959) sobre as medidas lineares deste grupo, para normalizá-las com os Grupos I e II e para que as comparações entre eles fossem confiáveis. Por exemplo, uma medida de 109,2 mm obtida no Grupo III, quando corrigida por este fator deve gerar 106 mm, ou seja, 109,2 mm X 0,9706959.

A escolha pela padronização (normalização) de uma ampliação de $6 \%$ das imagens radiográficas e não na eliminação total dos fatores de magnificação (base 0), baseou-se nos seguintes motivos:

- possibilidade de extrapolação e comparação dos resultados obtidos nesta pesquisa por ortodontistas na sua prática clínica, uma vez que, a maioria das radiografias exibem fatores de magnificação mínimos, próximos de $6 \%$;

- os valores obtidos por SATO $^{85}$, em 1982, baseando-se nos critérios estabelecidos por VIGORITO ${ }^{110}$, em 1972, utilizados como medidas normativas em norma frontal, foram obtidos com um fator de magnificação aproximadamente de $6 \%$.

Segundo FRANKLIN ${ }^{36}$ e GOLDREICH et al $^{38}$, o grau de magnificação apresenta-se como um problema inerente na cefalometria e depende basicamente de dois fatores : 1) distância foco-filme, ou seja, quanto maior a distância do ponto focal até o filme, menor a ampliação da imagem radiográfica; 2) distância objeto-filme, ou seja, quanto mais próximo o objeto do filme, menor a magnificação. 


\subsection{4) ELABORAÇÃO DO CEFALOGRAMA}

\subsubsection{1) MATERIAL}

O material utilizado para a realização do traçado cefalométrico constituiuse de :
a) Negatoscópio;
b) Folha de papel acetato "ultraphan" transparente, com 0,07 $\mathrm{mm}$ de espessura e dimensões de 17,5 x 17,5 cm;
c) Lapiseira com ponta fina $0,5 \mathrm{~mm}$;
d) Gabarito - "Template Dome de Ricketts";
e) Régua milimetrada;
f) Esquadro;
g) Transferidor;
h) Fita adesiva;
i) Borracha macia;
j) Máscara de cartolina preta. 


\subsubsection{2) CEFALOGRAMA}

Sobre cada radiografia adaptou-se uma folha do papel "ultraphan", fixada por meio de uma fita adesiva e traçaram-se as estruturas anatomoradiológicas de interesse para a elaboração do cefalograma. Este traçado foi realizado em uma sala obscurecida, sobre um negatoscópio, para facilitar a visualização e a evidenciação das estruturas.

O cefalograma constou de :

- desenho anatômico;

- pontos, linhas e planos de referência;

- grandezas cefalométricas lineares e angulares. 


\subsubsection{3) DESENHO ANATÔMICO (Figura 4.9)}

O traçado do desenho anatômico obedeceu aos critérios descritos por GUGINO $^{41}$ e MAZZIEIRO ${ }^{65}$ incluindo as estruturas e os contornos anatômicos listados a seguir:
a) Cavidade nasal;
b) Bordas laterais do crânio e processo mastóide;
c) Órbitas;
d) Suturas frontozigomáticas;
e) Arco zigomático;
f) Mandíbula;
g) Borda lateral da maxila;
h) Espinha nasal anterior;
i) Incisivos centrais superiores;
j) Incisivos centrais inferiores;
k) Primeiros molares superiores;
1) Primeiros molares inferiores;

Após a identificação das estruturas descritas, outro examinador as conferiu, para garantir uma ampla margem de segurança quanto à exatidão dos traçados. 


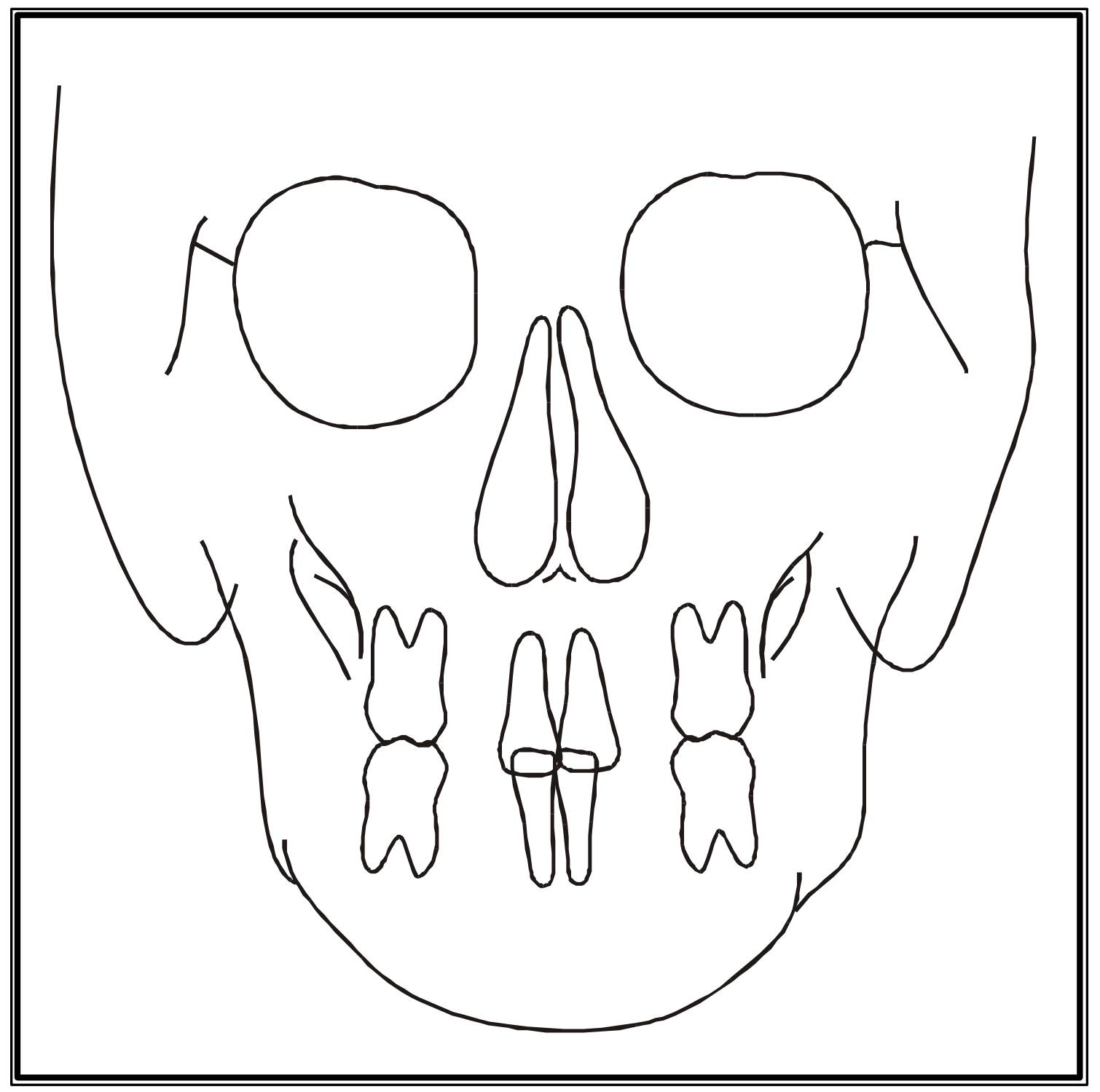

FIGURA 4.9 - Desenho Anatômico 


\subsubsection{4) DEMARCAÇÃO DOS PONTOS CEFALOMÉTRICOS DE REFERÊNCIA (Figura 4.10)}

Pontos cefalométricos utilizados na elaboração do cefalograma:

A) Pontos ZL e ZR - Pontos zigomáticos bilaterais sobre a margem medial da sutura frontozigomática, na intersecção das órbitas.

ZL - Esquerdo; ZR - Direito.

B) Pontos NC e CN - Pontos do contorno da cavidade nasal, na área de maior largura da porção inferior, na perspectiva frontal.

NC - Esquerdo; CN - Direito.

C) Pontos JL e JR - Pontos bilaterais sobre os processos jugais, na intersecção dos contornos da tuberosidade e do pilar zigomático.

JL - Esquerdo; JR - Direito.

D) Pontos AG e GA - Pontos bilaterais na margem inferior das protuberâncias antigonial, localizados na intersecção dos contornos gonial e antigonial.

AG - Esquerdo; GA - Direito. 
E) Pontos MI e IM - Pontos localizados nas superfícies mesiais dos incisivos centrais superiores, na região do ponto de contato entre os dois dentes. MI - Esquerdo; IM - Direito.

F) Pontos AI e IA - Pontos localizados nos ápices radiculares dos incisivos centrais superiores, na região cortada pelo longo eixo destes dentes.

AI - Esquerdo; IA - Direito.

G) Ponto ENA - Extremidade da espinha nasal anterior, logo abaixo da cavidade nasal e acima do palato duro.

H) Ponto Me - Ponto do bordo inferior da sínfise, diretamente inferior à protuberância mental e do centro do trigomium mentali. 


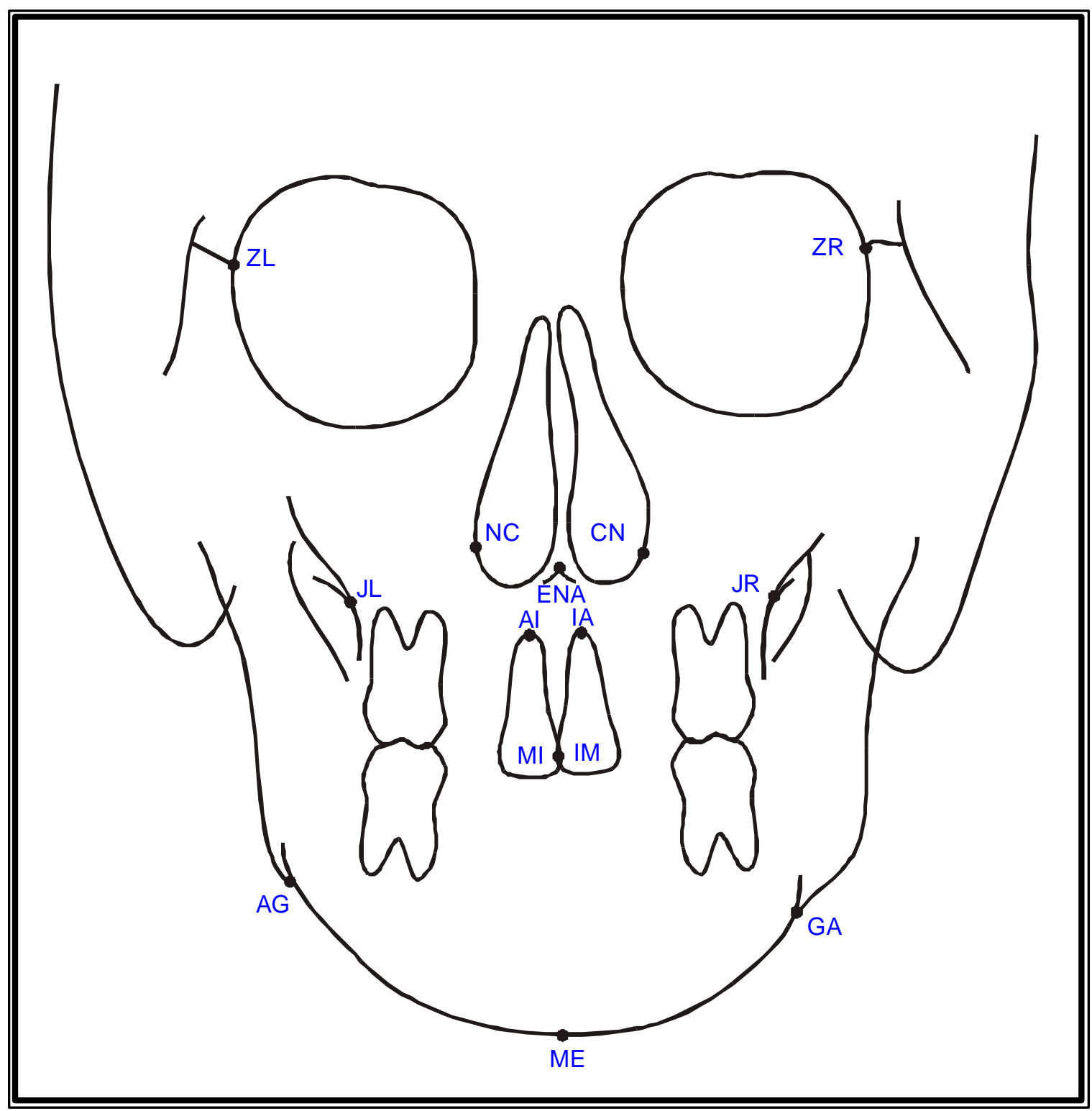

FIGURA 4.10 - Pontos Cefalométricos 


\subsubsection{5) DEMARCAÇÃO DOS PONTOS PROJETADOS (Figura} 4.11)

Pontos cefalométricos projetados sobre estruturas anatômicas e/ou planos de referência:

A) Pontos CS e SC - Pontos localizados nas superfícies vestibulares das coroas dos primeiros molares superiores, determinados por uma reta traçada paralela e superiormente $4 \mathrm{~mm}$ ao plano de oclusão (Plano determinado pela oclusão dos primeiros molares esquerdos e direitos).

CS - Esquerdo; SC - Direito.

B) Pontos RS e SR - Pontos localizados nas superfícies vestibulares das raízes dos primeiros molares superiores, determinados por uma reta traçada paralela e superiormente $18 \mathrm{~mm}$ ao plano de oclusão. RS - Esquerdo; SR - Direito.

C) Pontos CI e IC - Pontos localizados nas superfícies vestibulares das coroas dos primeiros molares inferiores, determinados por uma reta traçada paralela e inferiormente $4 \mathrm{~mm}$ ao plano de oclusão. CI - Esquerdo; IC - Direito. 
D) Pontos A6 e 6A - Pontos determinados pelas projeções das superfícies vestibulares dos primeiros molares superiores, perpendicularmente ao plano de oclusão. A6 - Esquerdo; 6A - Direito.

No Grupo III (expansor colado), acrescentou-se $1 \mathrm{~mm}$ para a determinação dos pontos projetados superior ou inferiormente ao plano de oclusão, na fase pós-expansão, devido ao levantamento oclusal na região posterior. Ex.: pontos CS e SC : pontos localizados nas superfícies vestibulares das coroas dos primeiros molares superiores, determinados por uma reta traçada paralela e superiormente $5 \mathrm{~mm}$ ao plano de oclusão. 


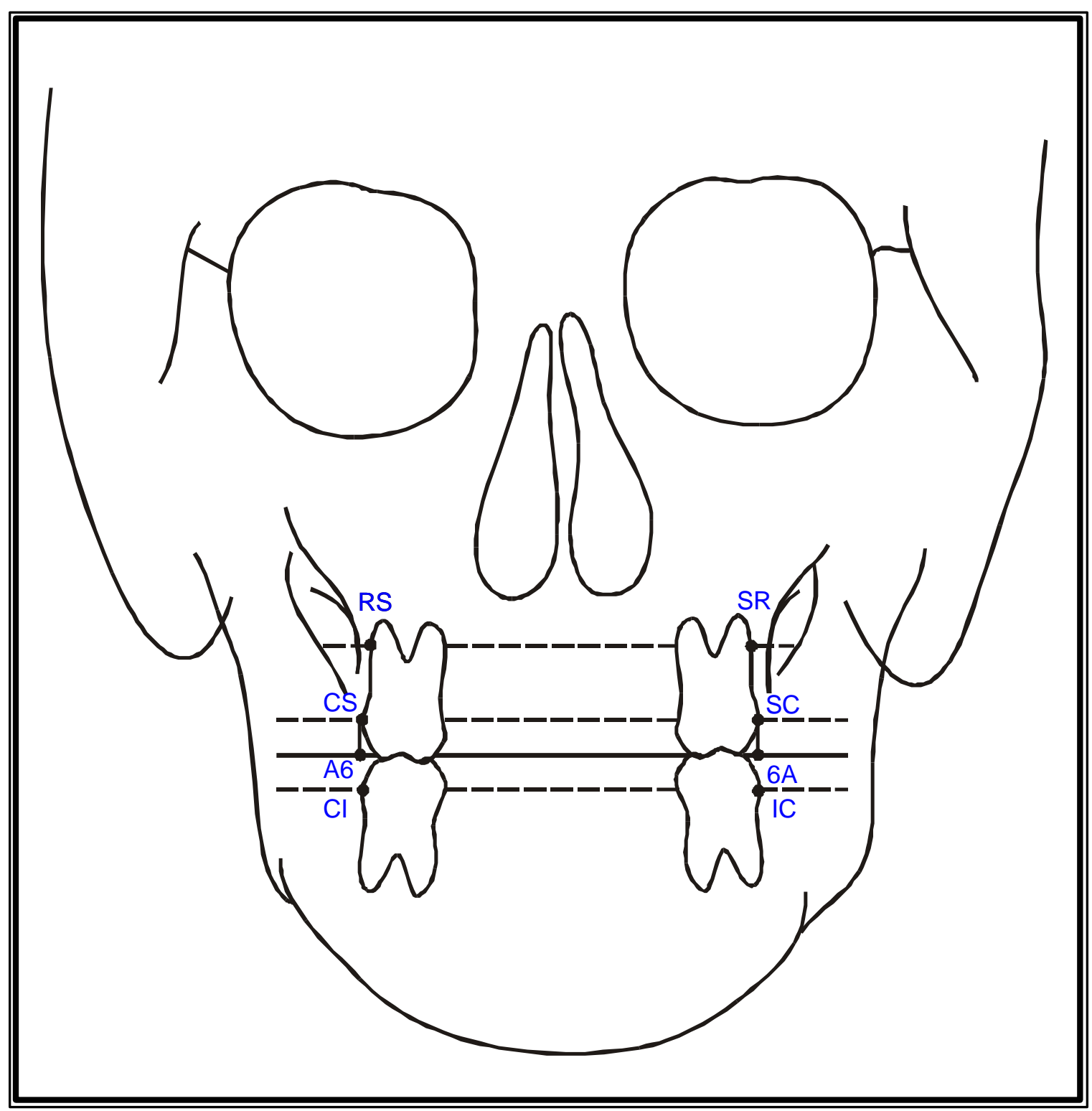

FIGURA 4.11 - Pontos Projetados 


\subsubsection{6) LINHAS E PLANOS DE REFERÊNCIA (Figura 4.12)}

A) Plano Z - Plano básico de referência, determinado pela união dos pontos ZL e ZR.

B) Linha NC-CN - Linha determinada pelos pontos $\mathrm{NC}$ e $\mathrm{CN}$, indicando a maior largura da cavidade nasal, na sua porção inferior.

C) Linha JL-JR - Linha determinada pelos pontos JL e JR, demonstrando a largura da maxila.

D) Plano de Oclusão - Plano determinado pela oclusão dos primeiros molares esquerdos e direitos.

E/F) Plano Frontal dos Dentes - Plano determinado pela união dos pontos JR-GA, no lado direito e JL-AG, no lado esquerdo.

G) Linha ENA - Me - Linha determinada pela união dos pontos ENA e Me. 


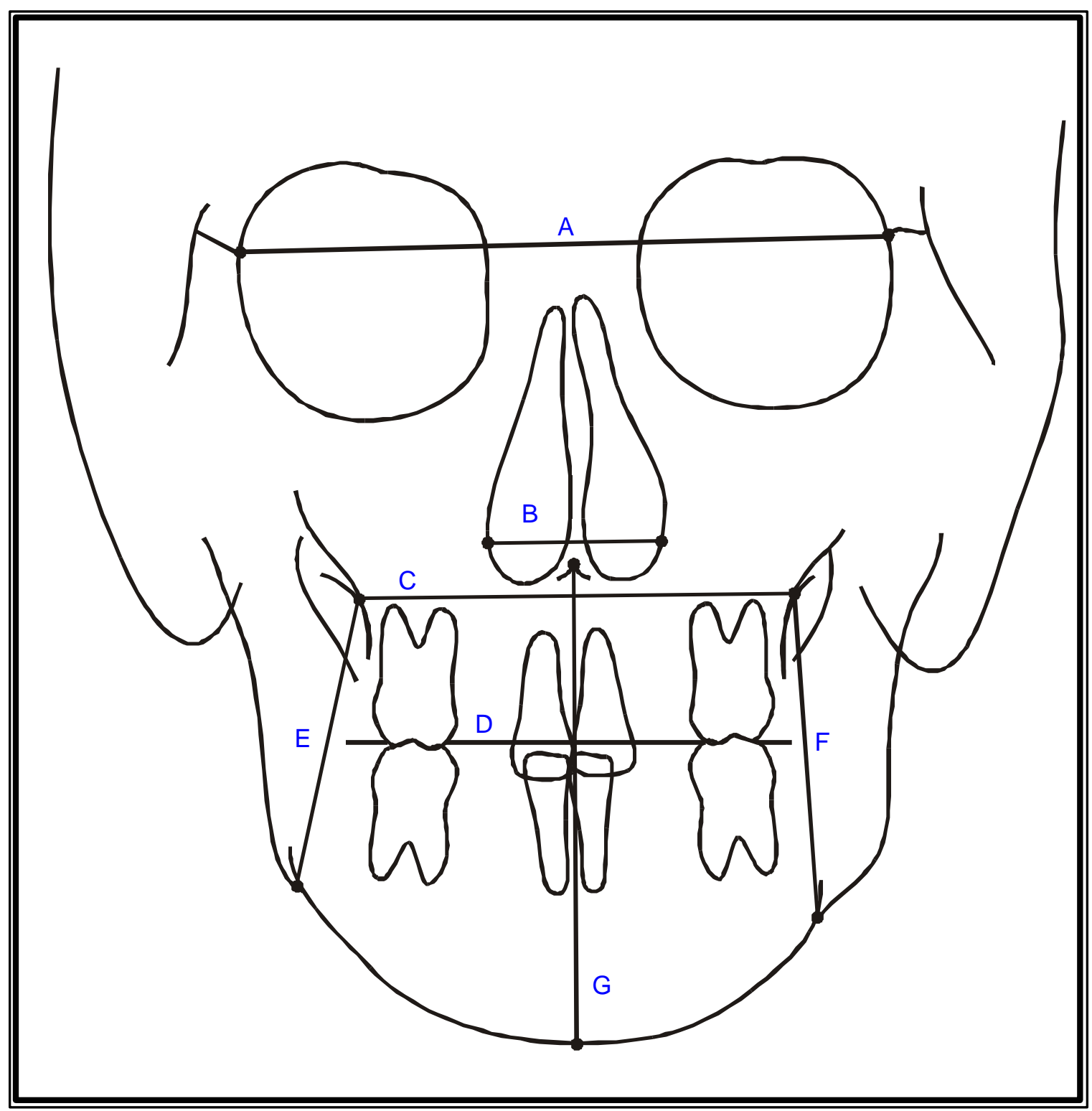

FIGURA 4.12 - Linhas e Planos de Referência
A) Plano Z
E) JL-AG
B) Linha NC-CN
F) JR-GA
C) Linha JL-JR
G) Linha ENA-ME
D) Plano de Oclusão 


\subsubsection{7) GRANDEZAS LINEARES (Figuras 4.13 e 4.14)}

A) Largura da Cavidade Nasal (NC-CN) - Distância, em milímetros, determinada entre os pontos $\mathrm{NC}$ e $\mathrm{CN}$.

B) Largura da Maxila (JL-JR) - Distância, em milímetros, determinada entre os pontos JL e JR.

C) Distância Interápices dos Molares Superiores (RSR) - Distância, em milímetros, determinada entre os pontos RS e SR.

D) Distância Intercoroas dos Molares Superiores (CSC) - Distância, em milímetros, determinada entre os pontos CS e SC.

E) Distância Interápices dos Incisivos Centrais Superiores (AI-IA) Distância, em milímetros, determinada entre os pontos AI e IA.

F) Distância Intercoroas dos Molares Inferiores (CIC) - Distância, em milímetros, determinada entre os pontos CI e IC.

G) Relação entre o Primeiro Molar Superior Esquerdo e o Plano Frontal dos Dentes (A6-JL) - Distância, em milímetros, determinada entre o ponto A6 e o plano JLAG, no lado esquerdo. A partir do ponto A6, traça-se uma perpendicular ao plano JLAG. 
H) Relação entre o Primeiro Molar Superior Direito e o Plano Frontal dos Dentes (6A-JR) - Distância, em milímetros, determinada entre o ponto $6 \mathrm{~A}$ e o plano JRGA, no lado direito. A partir do ponto 6A, traça-se uma perpendicular ao plano JRGA.

I) Diastemas Interincisivos (IM-MI) - Distância, em milímetros, determinada entre os pontos MI e IM.

J) Sobremordida (SOBREM.) - Distância, em milímetros, da superfície incisal do incisivo superior à superfície incisal do incisivo inferior. Atribui-se valores positivos (+) quando se observa a sobreposição das imagens dos incisivos. Quando não existe esta sobreposição, atribui-se valores negativos (-). Se os incisivos centrais superiores estiverem com trespasses verticais diferentes, obtêm-se a média, para a realização desta medida.

K) Altura Facial Ântero-Inferior (AFAI) - Distância, em milímetros, determinada entre os pontos ENA e ME.

Estas grandezas lineares foram mensuradas em milímetros e obtidas com o auxílio de uma régua milimetrada, com precisão de $0,5 \mathrm{~mm}$. 


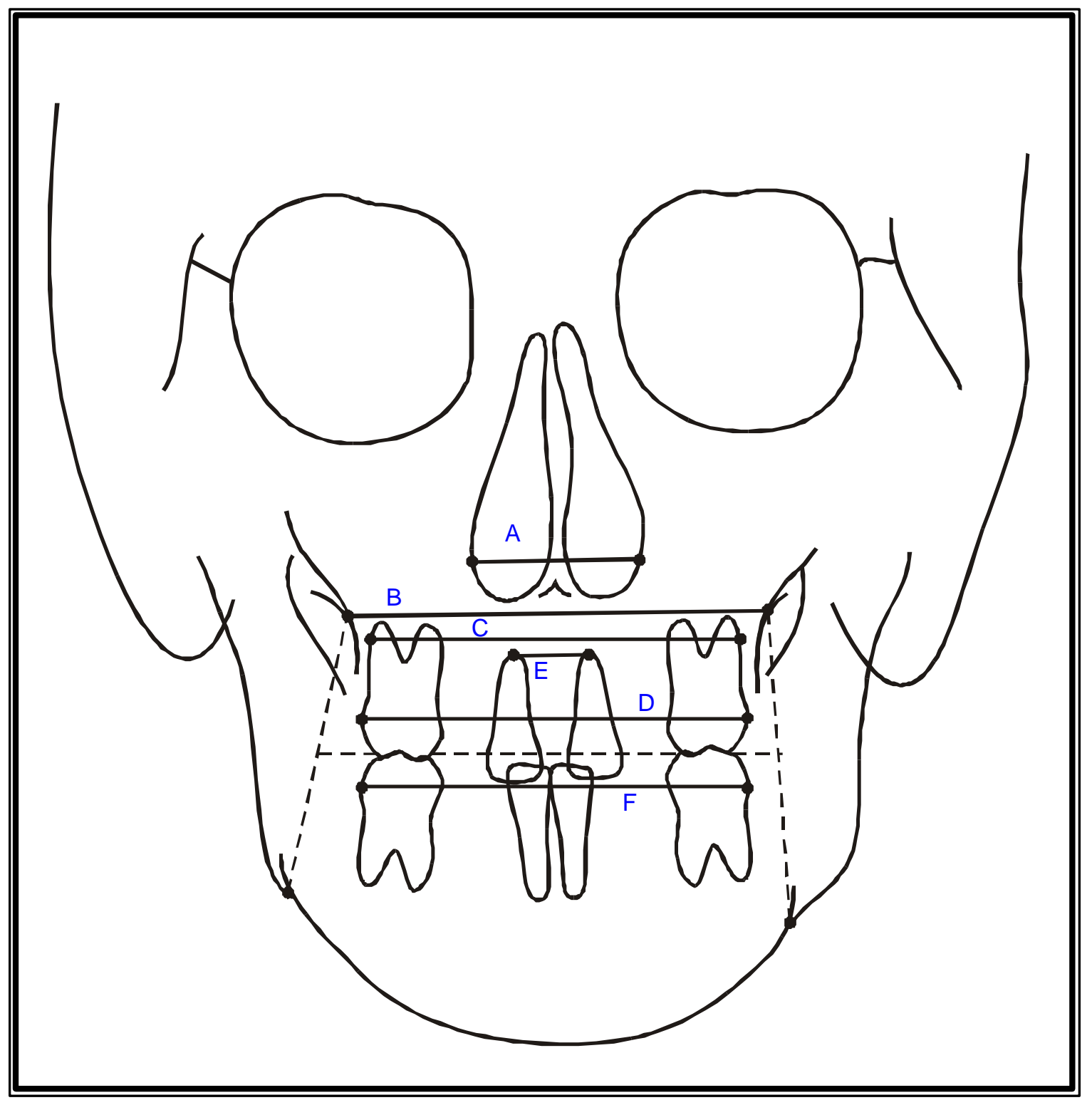

FIGURA 4.13 - Grandezas Lineares :
A) NC-CN
B) JL-JR
C) RSR
D) $\mathrm{CSC}$
E) AI-IA
F) $\mathrm{CIC}$ 


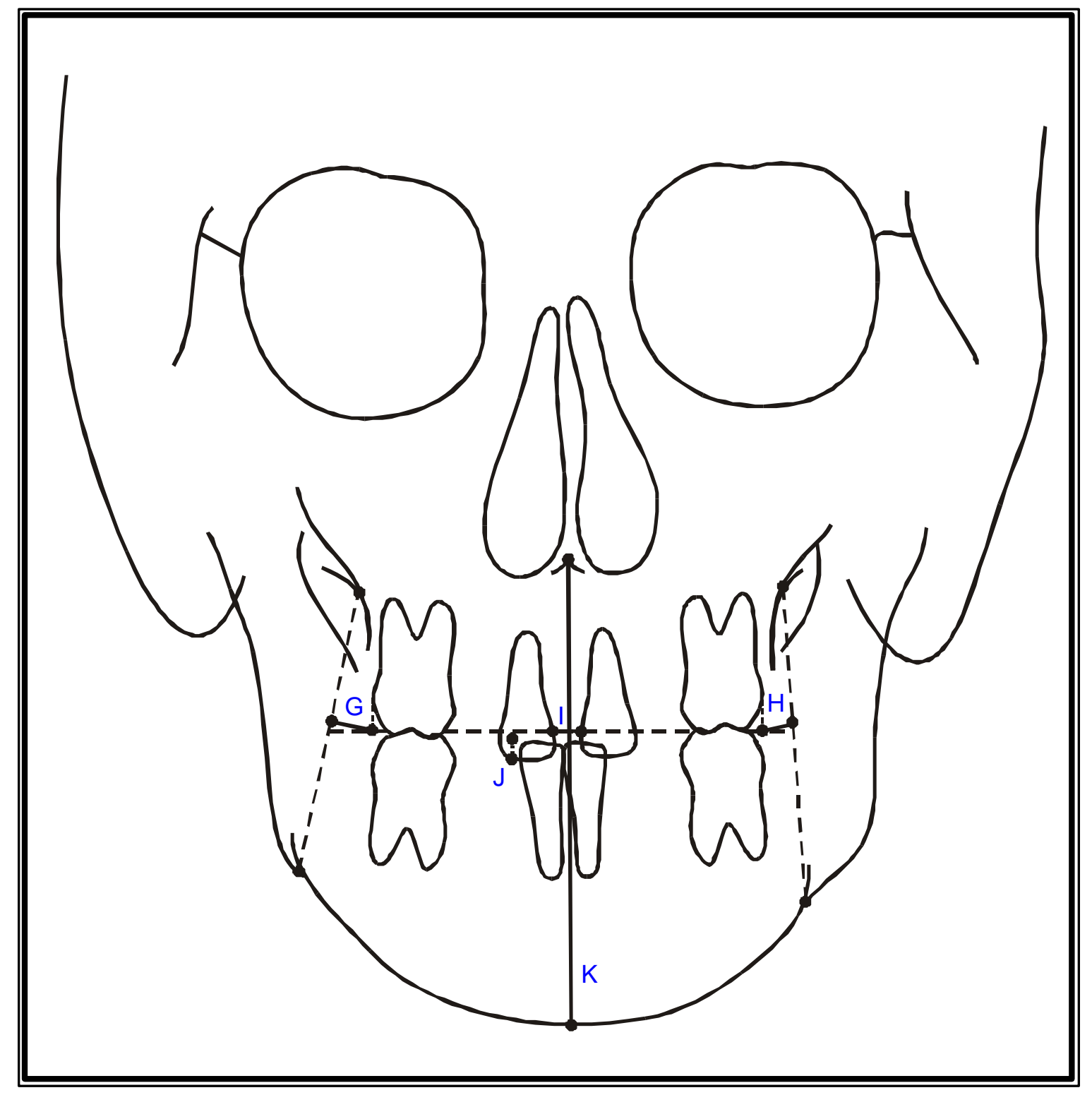

FIGURA 4.14 - Grandezas Lineares :

G) A6-JL

H) 6A-JR

I) IM-MI

J) SOBREM.

K) AFAI 


\subsubsection{8) GRANDEZAS ANGULARES (Figura 4.15)}

A) Longo eixo do primeiro molar superior esquerdo (6L.Z) - Medida angular entre o longo eixo deste dente e o plano $\mathrm{Z}$, obtida pelo lado vestibular. Determina-se o longo eixo traçando-se uma reta que passa pelo ponto médio da superfície oclusal da coroa e o ponto médio na região da furca. Esta deve se prolongar até o plano Z.

B) Longo eixo do primeiro molar superior direito (6R.Z) - Medida angular entre o longo eixo deste dente e o plano $\mathrm{Z}$, obtida pelo lado vestibular. Determina-se o longo eixo traçando-se uma reta que passa pelo ponto médio da superfície oclusal da coroa e o ponto médio na região da furca. Esta deve se prolongar até o plano Z.

C) Longo eixo do incisivo superior esquerdo (A1L.Z) - Medida angular entre o longo eixo deste dente e o plano Z, obtida pelo lado distal.

D) Longo eixo do incisivo superior direito (A1R.Z) - Medida angular entre o longo eixo deste dente e o plano $\mathrm{Z}$, obtida pelo lado distal.

Estas grandezas angulares foram mensuradas em graus e obtidas com o auxílio de um transferidor, com uma precisão de $0,5^{\circ}$. 


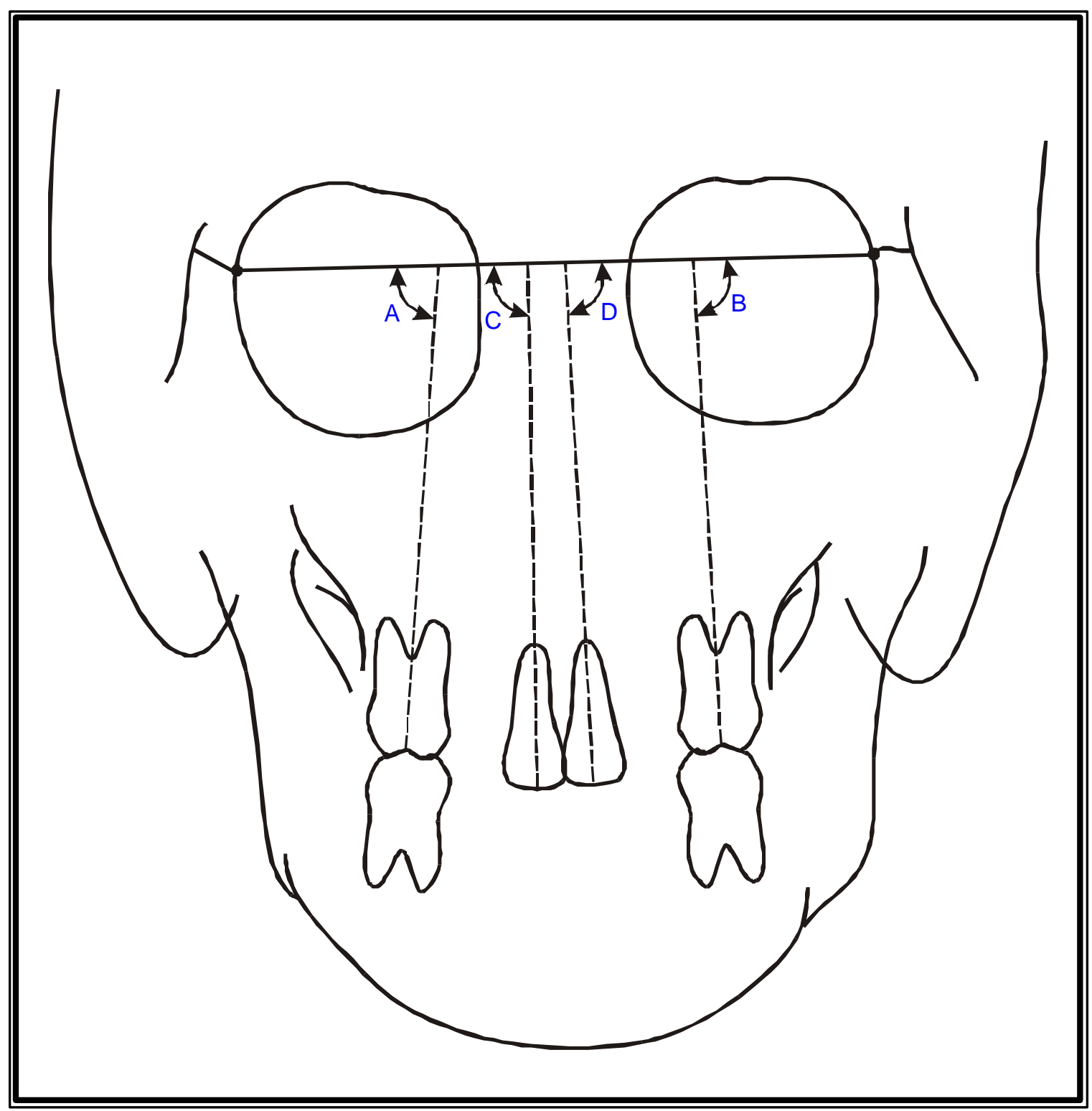

FIGURA 4.15- Grandezas Angulares :
A) $6 \mathrm{~L} . \mathrm{Z}$
B) $6 R . Z$
C) A1L.Z
D) A1R.Z 


\subsection{5) ANÁLISE ESTATÍSTICA *}

\subsubsection{1) ERRO DO MÉTODO :}

\subsubsection{1) ERRO INTRA-EXAMINADOR}

Para a obtenção do erro intra-examinador, foram retraçadas e medidas novamente as radiografias de cinco pacientes do Grupo III (expansor colado), selecionados aleatoriamente, após um período mínimo de dois meses. Utilizaram-se as radiografias nos três tempos (pré-expansão, pós-expansão e pós-contenção), totalizando 15 radiografias. Aplicou-se o teste $\mathrm{t}$ pareado (variáveis dependentes), para a verificação do erro sistemático e a fórmula de DAHLBERG $^{30}$, para estimar a ordem de grandeza dos erros casuais.

Fórmula de DAHLBERG : $\quad \mathrm{Se}^{2}=\frac{\text { somatório }^{2}}{2 \mathrm{n}}$

\subsubsection{2) ERRO INTEREXAMINADORES}

Com o objetivo de determinar a confiabilidade de se empregar os valores obtidos por MAZZIEIRO ${ }^{65}$, para o Grupo I (Haas modificado) e para o Grupo II (Hyrax modificado), foram retraçadas 12 radiografias escolhidas aleatoriamente e as medidas lineares e angulares obtidas, foram comparadas com as deste autor $^{65}$, utilizando o teste " $\mathrm{t}$ " para amostras dependentes.

* Orientação : Prof. José Roberto Pereira Lauris. 


\subsubsection{2) MÉTODO ESTATÍSTICO}

Utilizou-se o "software" STATISTICA for Windows (Stat. Soft. inc.) para a realização da análise, baseada nos seguintes critérios:

a) Estatística descritiva : médias, desvios-padrão, valor máximo e valor mínimo para todos os grupos;

b) Teste "t" pareado : comparação dos dados intragrupos;

c) Análise de Variância (ANOVA) : análise de variância a um critério (uma variável dependente), com múltiplas variáveis independentes e um modelo fixo. Esta foi utilizada na comparação intergrupos, pois apresenta-se como o teste mais indicado para amostras paramétricas, independentes e tomadas em tempos distintos;

d) Teste de Tukey : teste de comparação múltipla, utilizado para a determinação dos tempos ou grupos que demonstram as diferenças estatísticas, indicadas pela análise de variância. 
5. RESULTADOS 


\section{RESULTADOS}

Os valores obtidos das mensurações de cada variável cefalométrica para os três grupos (Grupo I- Haas modificado; Grupo II - Hyrax modificado; Grupo III - expansor colado), nos três tempos analisados (pré-expansão, pós-expansão e pós-contenção), em suas médias (X), desvios-padrão (D.P.) e comparações com a aplicação dos testes estatísticos, encontram-se dispostos nas tabelas e nos gráficos a seguir. Cabe ressaltar, que os valores do Grupo I e do Grupo II foram obtidos por MAZZIEIRO ${ }^{65}$, em 1994.

As Tabelas 5.1, 5.2 e 5.3 exibem as médias e desvios-padrão das medidas cefalométricas analisadas nos Grupo I, II e III, nas fases pré-expansão (1), pósexpansão (2) e pós-contenção (3).

As Tabelas 5.4 a 5.12 demonstram as médias e desvios-padrão das medidas cefalométricas e das diferenças entre as fases analisadas, observadas nos Grupos I, II e III, assim como a significância estatística.

As Tabelas 5.13, 5.14 e 5.15 apresentam as médias, desvios-padrão das diferenças das medidas cefalométricas analisadas nas três fases, o valor de "F" (utilizado para o cálculo estatístico), de "p" (nível de significância) e a significância estatística observada pela análise de variância (ANOVA) aplicada na comparação dos três grupos estudados.

As Tabelas 5.16 a 5.27 demonstram as comparações entre os três grupos, com as médias e o valor de "p", realizada com o teste de Tukey, para as variáveis que apresentaram diferenças estatisticamente significantes na análise de variância.

A Tabela 5.28 exibe os erros casuais (Dahlberg), nos três tempos das radiografias, demonstrando a análise intra-examinador da precisão do método cefalométrico. A Tabela 5.29 apresenta os valores iniciais e repetidos após 2 
meses (médias e desvios-padrão), diferença das médias, valor de “T”, de "p" e a significância estatística dos erros sistemáticos. A Tabela 5.30 ilustra a análise interexaminadores da precisão do método e a Tabela 5.31 demonstra as médias (X), desvios-padrão (D.P.) dos valores iniciais (fase pré-expansão), valor de "p" e a significância estatística da análise de variância aplicada na comparação dos três grupos.

Os Gráficos 5.1 a 5.15 demonstram os valores médios das variáveis analisadas para os três grupos, nas fases pré-expansão, pós-expansão e póscontenção. Para facilitar a visualização da magnitude das alterações ocorridas, os Gráficos 5.16 a 5.27 exibem as variações percentuais dos três grupos estudados, nos períodos : - pré-expansão até pós-expansão; - pós-expansão até pós-contenção; - pré-expansão até pós-contenção. Não foi possível a realização deste tipo de gráfico para a variável IM-MI, uma vez que ela demonstrava valores iniciais iguais a zero. Devido à grande variação das medidas SOBREM. e AFAI, também não foi possível a confecção destes gráficos percentuais.

Os resultados individuais para todas as variáveis analisadas nos três grupos, assim como seus valores máximos e mínimos nas fases pré-expansão, pós-expansão e pós-contenção, se encontram nos ANEXOS. 
TABELA 5.1 : Médias (X) e desvios-padrão (D.P.) das medidas cefalométricas analisadas no Grupo I (aparelhos expansores dentomucossuportados - tipo Haas), nas fases pré-expansão (1), pós-expansão (2) e pós-contenção (3).

\begin{tabular}{|c|c|c|c|c|c|c|c|}
\hline \multicolumn{2}{|c|}{ FASE } & \multicolumn{2}{|c|}{$\begin{array}{c}(1) \\
\text { PRÉ- } \\
\text { EXPANSÃO }\end{array}$} & \multicolumn{2}{|c|}{$\begin{array}{c}\text { (2) } \\
\text { PÓS- } \\
\text { EXPANSÃO } \\
\end{array}$} & \multicolumn{2}{|c|}{$\begin{array}{c}\text { (3) } \\
\text { PÓS- } \\
\text { CONTENÇÃO } \\
\end{array}$} \\
\hline $\begin{array}{l}\text { Tipo } \\
\text { Haas }\end{array}$ & $\begin{array}{l}\mathrm{N} \\
20\end{array}$ & X & D.P. & X & D.P. & X & D.P. \\
\hline \multicolumn{8}{|c|}{ Variáveis } \\
\hline \multicolumn{2}{|c|}{$\mathrm{NC}-\mathrm{CN}$} & 28,92 & 2,29 & 30,85 & 2,15 & 31,05 & 2,64 \\
\hline \multicolumn{2}{|c|}{ JL-JR } & 61,25 & 2,73 & 63,42 & 2,71 & 62,95 & 2,67 \\
\hline \multicolumn{2}{|c|}{ RSR } & 48,37 & 3,34 & 52,85 & 4,04 & 52,9 & 3,21 \\
\hline \multicolumn{2}{|c|}{$\mathrm{CSC}$} & 55,67 & 3,02 & 60,65 & 4,45 & 61,55 & 3,76 \\
\hline \multicolumn{2}{|c|}{ CIC } & 57,12 & 3,52 & 57,72 & 4,00 & 58,82 & 3,56 \\
\hline \multicolumn{2}{|c|}{ A6-JL } & 7,65 & 1,63 & 5,95 & 1,54 & 5,95 & 1,53 \\
\hline \multicolumn{2}{|c|}{ 6A-JR } & 7,35 & 1,53 & 5,57 & 1,37 & 5,3 & 1,66 \\
\hline \multicolumn{2}{|c|}{ 6R.Z } & 79,50 & 4,31 & 75,30 & 6,30 & 74,1 & 6,39 \\
\hline \multicolumn{2}{|c|}{ 6L.Z } & 70,20 & 2,93 & 69,12 & 6,46 & 67,65 & 4,09 \\
\hline \multicolumn{2}{|c|}{ AI-IA } & 7,25 & 1,05 & 10,65 & 2,23 & 9,92 & 2,30 \\
\hline \multicolumn{2}{|c|}{ IM-MI } & 0,00 & 0,00 & 2,75 & 1,01 & 0,15 & 0,67 \\
\hline \multicolumn{2}{|c|}{ A1R.Z } & 88,77 & 4,65 & 88,95 & 5,86 & 91,5 & 4,32 \\
\hline \multicolumn{2}{|c|}{ A1L.Z } & 86,4 & 4,46 & 89,00 & 4,82 & 90,32 & 6,05 \\
\hline \multicolumn{2}{|c|}{ SOBREM. } & 1,22 & 1,39 & $-0,80$ & 1,42 & 0,90 & 1,43 \\
\hline \multicolumn{2}{|c|}{ AFAI } & 65,55 & 5,88 & 68,2 & 5,51 & 67,65 & 5,33 \\
\hline
\end{tabular}


TABELA 5.2 : Médias (X) e desvios-padrão (D.P.) das medidas cefalométricas analisadas no Grupo II (aparelhos expansores dentossuportados - tipo Hyrax), nas fases pré-expansão (1), pós-expansão (2) e pós-contenção (3).

\begin{tabular}{|c|c|c|c|c|c|c|c|}
\hline \multicolumn{2}{|c|}{ FASE } & \multicolumn{2}{|c|}{$\begin{array}{c}\text { (1) } \\
\text { PRÉ- } \\
\text { EXPANSÃO }\end{array}$} & \multicolumn{2}{|c|}{$\begin{array}{c}(2) \\
\text { PÓS- } \\
\text { EXPANSÃO }\end{array}$} & \multicolumn{2}{|c|}{$\begin{array}{c}\text { (3) } \\
\text { PÓS- } \\
\text { CONTENÇÃo }\end{array}$} \\
\hline $\begin{array}{l}\text { Tipo } \\
\text { Hyrax }\end{array}$ & $\begin{array}{l}N \\
21\end{array}$ & $\mathrm{X}$ & D.P. & $X$ & D.P. & $X$ & D.P. \\
\hline \multicolumn{8}{|c|}{ Variáveis } \\
\hline \multicolumn{2}{|c|}{$\mathrm{NC}-\mathrm{CN}$} & 29,38 & 3,02 & 31,23 & 2,64 & 31,73 & 2,42 \\
\hline \multicolumn{2}{|c|}{ JL-JR } & 61,85 & 3,02 & 64,00 & 3,16 & 63,83 & 2,79 \\
\hline \multicolumn{2}{|c|}{ RSR } & 48,30 & 3,70 & 52,54 & 3,83 & 53,28 & 3,52 \\
\hline \multicolumn{2}{|c|}{$\mathrm{CSC}$} & 55,57 & 2,83 & 61,40 & 3,19 & 61,59 & 3,13 \\
\hline \multicolumn{2}{|c|}{ CIC } & 57,92 & 3,19 & 58,92 & 3,29 & 58,81 & 2,73 \\
\hline \multicolumn{2}{|c|}{ A6-JL } & 8,09 & 1,86 & 6,02 & 1,74 & 5,81 & 2,01 \\
\hline \multicolumn{2}{|c|}{ 6A-JR } & 7,40 & 1,44 & 5,59 & 1,79 & 5,52 & 1,92 \\
\hline \multicolumn{2}{|c|}{ 6R.Z } & 78,66 & 4,62 & 75,35 & 6,11 & 75,71 & 6,43 \\
\hline \multicolumn{2}{|c|}{ 6L.Z } & 69,38 & 3,77 & 66,64 & 4,66 & 67,16 & 3,55 \\
\hline \multicolumn{2}{|c|}{ AI-IA } & 6,57 & 1,46 & 9,90 & 2,67 & 10,07 & 2,27 \\
\hline \multicolumn{2}{|c|}{ IM-MI } & 0,00 & 0,00 & 3,23 & 1,35 & 0,19 & 0,51 \\
\hline \multicolumn{2}{|c|}{ A1R.Z } & 87,04 & 3,65 & 89,04 & 4,82 & 92,42 & 4,48 \\
\hline \multicolumn{2}{|c|}{ A1L.Z } & 86,61 & 5,31 & 85,11 & 6,23 & 91,52 & 6,07 \\
\hline \multicolumn{2}{|c|}{ SOBREM. } & 0,90 & 2,21 & $-0,19$ & 1,59 & 0,88 & 1,17 \\
\hline \multicolumn{2}{|c|}{ AFAI } & 64,09 & 4,74 & 66,52 & 4,52 & 65,69 & 5,06 \\
\hline
\end{tabular}


TABELA 5.3 : Médias (X) e desvios-padrão (D.P.) das medidas cefalométricas analisadas no Grupo III (aparelhos expansores dentossuportado colado), nas fases pré-expansão (1), pós-expansão (2) e póscontenção (3).

\begin{tabular}{|c|c|c|c|c|c|c|c|}
\hline \multicolumn{2}{|c|}{ FASE } & \multicolumn{2}{|c|}{$\begin{array}{c}\text { (1) } \\
\text { PRÉ- } \\
\text { EXPANSÃO }\end{array}$} & \multicolumn{2}{|c|}{$\begin{array}{c}(2) \\
\text { PÓS- } \\
\text { EXPANSÃO }\end{array}$} & \multicolumn{2}{|c|}{$\begin{array}{c}\text { (3) } \\
\text { PÓS- } \\
\text { CONTENÇÃo }\end{array}$} \\
\hline $\begin{array}{c}\text { Tipo } \\
\text { Colado }\end{array}$ & $\begin{array}{l}\mathrm{N} \\
22\end{array}$ & $\mathrm{X}$ & D.P. & $X$ & D.P. & $X$ & D.P. \\
\hline \multicolumn{8}{|c|}{ Variáveis } \\
\hline \multicolumn{2}{|c|}{$\mathrm{NC}-\mathrm{CN}$} & 27,08 & 2,20 & 28,93 & 1,99 & 28,85 & 1,96 \\
\hline \multicolumn{2}{|c|}{ JL-JR } & 60,50 & 2,96 & 63,12 & 2,91 & 63,20 & 3,03 \\
\hline \multicolumn{2}{|c|}{ RSR } & 47,20 & 3,77 & 51,74 & 3,99 & 53,04 & 3,84 \\
\hline \multicolumn{2}{|c|}{$\mathrm{CSC}$} & 52,44 & 3,35 & 59,11 & 3,16 & 59,84 & 2,99 \\
\hline \multicolumn{2}{|c|}{ CIC } & 56,22 & 2,71 & 56,32 & 2,51 & 56,36 & 2,81 \\
\hline \multicolumn{2}{|c|}{ A6-JL } & 8,99 & 1,89 & 6,79 & 1,57 & 6,31 & 1,87 \\
\hline \multicolumn{2}{|c|}{ 6A-JR } & 8,81 & 2,28 & 6,23 & 2,02 & 5,81 & 1,94 \\
\hline \multicolumn{2}{|c|}{ 6R.Z } & 79,75 & 3,77 & 72,40 & 5,10 & 72,93 & 4,27 \\
\hline \multicolumn{2}{|c|}{ 6L.Z } & 84,09 & 4,08 & 76,88 & 3,52 & 79,63 & 4,09 \\
\hline \multicolumn{2}{|c|}{ AI-IA } & 6,57 & 1,40 & 11,08 & 2,06 & 9,57 & 1,81 \\
\hline \multicolumn{2}{|c|}{ IM-MI } & 0,43 & 0,69 & 3,46 & 0,77 & 0,20 & 0,38 \\
\hline \multicolumn{2}{|c|}{ A1R.Z } & 88,31 & 3,65 & 92,38 & 4,21 & 93,93 & 4,39 \\
\hline \multicolumn{2}{|c|}{ A1L.Z } & 86,13 & 3,55 & 89,79 & 5,27 & 91,81 & 4,09 \\
\hline \multicolumn{2}{|c|}{ SOBREM. } & 1,35 & 1,96 & - & - & 0,98 & 1,73 \\
\hline \multicolumn{2}{|c|}{ AFAI } & 64,52 & 6,90 & - & - & 65,60 & 6,92 \\
\hline
\end{tabular}


TABELA 5.4 : Significância estatística, médias (X) e desvios-padrão (D.P.) das medidas cefalométricas e das diferenças entre as fases préexpansão (1) e pós-expansão (2), observadas no Grupo I (aparelhos expansores dentomucossuportados - tipo Haas).

\begin{tabular}{|c|c|c|c|c|c|c|c|c|}
\hline \multicolumn{2}{|c|}{ FASE } & \multicolumn{2}{|c|}{$\begin{array}{c}\text { (1) } \\
\text { PRÉ- } \\
\text { EXPANSÃO } \\
\end{array}$} & \multicolumn{2}{|c|}{$\begin{array}{c}\text { (2) } \\
\text { PÓS- } \\
\text { EXPANSÃO } \\
\end{array}$} & \multicolumn{2}{|c|}{$\begin{array}{l}\text { Diferença } \\
\text { (2) - (1) }\end{array}$} & \multirow[t]{2}{*}{$\begin{array}{l}\text { Signifi- } \\
\text { cância }\end{array}$} \\
\hline $\begin{array}{l}\text { Tipo } \\
\text { Haas }\end{array}$ & $\begin{array}{l}\mathrm{N} \\
20 \\
\end{array}$ & $\mathrm{X}$ & D.P. & $X$ & D.P. & $X$ & D.P. & \\
\hline \multicolumn{9}{|c|}{ Variáveis } \\
\hline \multicolumn{2}{|c|}{$\mathrm{NC}-\mathrm{CN}$} & 28,92 & 2,29 & 30,85 & 2,15 & 1,92 & 1,25 & $*$ \\
\hline \multicolumn{2}{|c|}{ JL-JR } & 61,25 & 2,73 & 63,42 & 2,71 & 2,17 & 1,64 & $*$ \\
\hline \multicolumn{2}{|c|}{ RSR } & 48,37 & 3,34 & 52,85 & 4,04 & 4,47 & 2,58 & $*$ \\
\hline \multicolumn{2}{|c|}{ CSC } & 55,67 & 3,02 & 60,65 & 4,45 & 4,97 & 3,28 & $*$ \\
\hline \multicolumn{2}{|c|}{ CIC } & 57,12 & 3,52 & 57,72 & 4,00 & 0,60 & 1,51 & ns \\
\hline \multicolumn{2}{|c|}{ A6-JL } & 7,65 & 1,63 & 5,95 & 1,54 & $-1,70$ & 1,55 & $*$ \\
\hline \multicolumn{2}{|c|}{ 6A-JR } & 7,35 & 1,53 & 5,57 & 1,37 & $-1,77$ & 1,69 & $*$ \\
\hline \multicolumn{2}{|c|}{ 6R.Z } & 79,50 & 4,31 & 75,30 & 6,30 & $-4,20$ & 7,31 & $*$ \\
\hline \multicolumn{2}{|c|}{ 6L.Z } & 70,20 & 2,93 & 69,12 & 6,46 & $-1,07$ & 6,07 & ns \\
\hline \multicolumn{2}{|c|}{ AI-IA } & 7,25 & 1,05 & 10,65 & 2,23 & 3,40 & 1,93 & $*$ \\
\hline \multicolumn{2}{|c|}{ IM-MI } & 0,00 & 0,00 & 2,75 & 1,01 & 2,75 & 1,01 & $*$ \\
\hline \multicolumn{2}{|c|}{ A1R.Z } & 88,77 & 4,65 & 88,95 & 5,86 & 0,17 & 4,31 & ns \\
\hline \multicolumn{2}{|c|}{ A1L.Z } & 86,4 & 4,46 & 89,00 & 4,82 & 2,60 & 4,39 & $\mathrm{~ns}$ \\
\hline \multicolumn{2}{|c|}{ SOBREM. } & 1,22 & 1,39 & $-0,80$ & 1,42 & $-2,02$ & 1,09 & * \\
\hline \multicolumn{2}{|c|}{ AFAI } & 65,55 & 5,88 & 68,20 & 5,51 & 2,65 & 1,49 & $*$ \\
\hline
\end{tabular}

* - estatisticamente significante $(\mathrm{p}<0,05)$

ns - estatisticamente não significante 
TABELA 5.5 : Significância estatística, médias (X) e desvios-padrão (D.P.) das medidas cefalométricas e das diferenças entre as fases pósexpansão (2) e pós-contenção (3), observadas no Grupo I (aparelhos expansores dentomucossuportados - tipo Haas).

\begin{tabular}{|c|c|c|c|c|c|c|c|c|}
\hline \multicolumn{2}{|c|}{ FASE } & \multicolumn{2}{|c|}{$\begin{array}{c}(2) \\
\text { PÓS- } \\
\text { EXPANSÃO }\end{array}$} & \multicolumn{2}{|c|}{$\begin{array}{c}\text { (3) } \\
\text { PÓS- } \\
\text { CONTENÇÃO } \\
\end{array}$} & \multicolumn{2}{|c|}{$\begin{array}{c}\text { Diferença } \\
\text { (3) - (2) }\end{array}$} & \multirow[t]{2}{*}{$\begin{array}{l}\text { Signifi- } \\
\text { cância }\end{array}$} \\
\hline $\begin{array}{l}\text { Tipo } \\
\text { Haas }\end{array}$ & $\begin{array}{l}\mathrm{N} \\
20 \\
\end{array}$ & $\mathrm{X}$ & D.P. & $X$ & D.P. & $X$ & D.P. & \\
\hline \multicolumn{9}{|c|}{ Variáveis } \\
\hline \multicolumn{2}{|c|}{$\mathrm{NC}-\mathrm{CN}$} & 30,85 & 2,15 & 31,05 & 2,64 & 0,2 & 1,19 & $\mathrm{~ns}$ \\
\hline \multicolumn{2}{|c|}{ JL-JR } & 63,42 & 2,71 & 62,95 & 2,67 & $-0,47$ & 1,08 & ns \\
\hline \multicolumn{2}{|c|}{ RSR } & 52,85 & 4,04 & 52,90 & 3,21 & 0,05 & 2,99 & ns \\
\hline \multicolumn{2}{|c|}{$\mathrm{CSC}$} & 60,65 & 4,45 & 61,55 & 3,76 & 0,90 & 3,13 & ns \\
\hline \multicolumn{2}{|c|}{$\mathrm{CIC}$} & 57,72 & 4,00 & 58,82 & 3,56 & 1,10 & 2,12 & ns \\
\hline \multicolumn{2}{|c|}{ A6-JL } & 5,95 & 1,54 & 5,95 & 1,53 & 0,00 & 1,13 & $\mathrm{~ns}$ \\
\hline \multicolumn{2}{|c|}{ 6A-JR } & 5,57 & 1,37 & 5,30 & 1,66 & $-0,27$ & 1,51 & ns \\
\hline \multicolumn{2}{|c|}{ 6R.Z } & 75,30 & 6,30 & 74,10 & 6,39 & $-1,20$ & 9,00 & ns \\
\hline \multicolumn{2}{|c|}{ 6L.Z } & 69,12 & 6,46 & 67,65 & 4,09 & $-1,47$ & 6,98 & ns \\
\hline \multicolumn{2}{|c|}{ AI-IA } & 10,65 & 2,23 & 9,92 & 2,30 & $-0,72$ & 1,56 & ns \\
\hline \multicolumn{2}{|c|}{ IM-MI } & 2,75 & 1,01 & 0,15 & 0,67 & $-2,60$ & 1,18 & $*$ \\
\hline \multicolumn{2}{|c|}{ A1R.Z } & 88,95 & 5,86 & 91,50 & 4,32 & 2,55 & 6,17 & ns \\
\hline \multicolumn{2}{|c|}{ A1L.Z } & 89,00 & 4,82 & 90,32 & 6,00 & 1,32 & 5,88 & ns \\
\hline \multicolumn{2}{|c|}{ SOBREM. } & $-0,80$ & 1,42 & 0,90 & 1,43 & 1,70 & 0,97 & $*$ \\
\hline \multicolumn{2}{|c|}{ AFAI } & 68,20 & 5,51 & 67,65 & 5,33 & $-0,55$ & 1,35 & ns \\
\hline
\end{tabular}

* - estatisticamente significante $(\mathrm{p}<0,05)$

ns - estatisticamente não significante 
TABELA 5.6 : Significância estatística, médias (X) e desvios-padrão (D.P.) das medidas cefalométricas e das diferenças entre as fases préexpansão (1) e pós-contenção (3), observadas no Grupo I (aparelhos expansores dentomucossuportados - tipo Haas).

\begin{tabular}{|c|c|c|c|c|c|c|c|c|}
\hline \multicolumn{2}{|c|}{ FASE } & \multicolumn{2}{|c|}{$\begin{array}{c}\text { (1) } \\
\text { PRÉ- } \\
\text { EXPANSÃO } \\
\end{array}$} & \multicolumn{2}{|c|}{$\begin{array}{c}\text { (3) } \\
\text { PÓS- } \\
\text { CONTENÇÃO } \\
\end{array}$} & \multicolumn{2}{|c|}{$\begin{array}{l}\text { Diferença } \\
\text { (3) - (1) }\end{array}$} & \multirow[t]{2}{*}{$\begin{array}{l}\text { Signifi- } \\
\text { cância }\end{array}$} \\
\hline $\begin{array}{l}\text { Tipo } \\
\text { Haas }\end{array}$ & $\begin{array}{l}\mathrm{N} \\
20 \\
\end{array}$ & $\mathrm{X}$ & D.P. & $X$ & D.P. & $X$ & D.P. & \\
\hline \multicolumn{9}{|c|}{ Variáveis } \\
\hline \multicolumn{2}{|c|}{$\mathrm{NC}-\mathrm{CN}$} & 28,92 & 2,29 & 31,05 & 2,64 & 2,12 & 1,12 & $*$ \\
\hline \multicolumn{2}{|c|}{ JL-JR } & 61,25 & 2,73 & 62,95 & 2,67 & 1,70 & 1,33 & $*$ \\
\hline \multicolumn{2}{|c|}{ RSR } & 48,37 & 3,34 & 52,90 & 3,21 & 4,52 & 3,49 & $*$ \\
\hline \multicolumn{2}{|c|}{ CSC } & 55,67 & 3,02 & 61,55 & 3,76 & 5,87 & 2,15 & $*$ \\
\hline \multicolumn{2}{|c|}{ CIC } & 57,12 & 3,52 & 58,82 & 3,56 & 1,70 & 2,38 & $*$ \\
\hline \multicolumn{2}{|c|}{ A6-JL } & 7,65 & 1,63 & 5,95 & 1,53 & $-1,70$ & 1,78 & $*$ \\
\hline \multicolumn{2}{|c|}{ 6A-JR } & 7,35 & 1,53 & 5,30 & 1,66 & $-2,05$ & 1,30 & $*$ \\
\hline \multicolumn{2}{|c|}{ 6R.Z } & 79,50 & 4,31 & 74,10 & 6,39 & $-5,40$ & 5,41 & $*$ \\
\hline \multicolumn{2}{|c|}{ 6L.Z } & 70,20 & 2,93 & 67,65 & 4,09 & $-2,55$ & 4,87 & ns \\
\hline \multicolumn{2}{|c|}{ AI-IA } & 7,25 & 1,05 & 9,92 & 2,30 & 2,67 & 1,94 & $*$ \\
\hline \multicolumn{2}{|c|}{ IM-MI } & 0,00 & 0,00 & 0,15 & 0,67 & 0,15 & 0,67 & ns \\
\hline \multicolumn{2}{|c|}{ A1R.Z } & 88,77 & 4,65 & 91,50 & 4,32 & 2,72 & 4,84 & ns \\
\hline \multicolumn{2}{|c|}{ A1L.Z } & 86,40 & 4,46 & 90,32 & 6,05 & 3,92 & 6,53 & $*$ \\
\hline \multicolumn{2}{|c|}{ SOBREM. } & 1,22 & 1,39 & 0,90 & 1,43 & $-0,32$ & 1,33 & ns \\
\hline \multicolumn{2}{|c|}{ AFAI } & 65,55 & 5,88 & 67,65 & 5,33 & 2,10 & 2,07 & $*$ \\
\hline
\end{tabular}

* - estatisticamente significante $(\mathrm{p}<0,05)$

ns - estatisticamente não significante 
TABELA 5.7 : Significância estatística, médias (X) e desvios-padrão (D.P.) das medidas cefalométricas e das diferenças entre as fases préexpansão (1) e pós-expansão (2), observadas no Grupo II (aparelhos expansores dentossuportados - tipo Hyrax).

\begin{tabular}{|c|c|c|c|c|c|c|c|c|}
\hline \multicolumn{2}{|c|}{ FASE } & \multicolumn{2}{|c|}{$\begin{array}{c}\text { (1) } \\
\text { PRÉ- } \\
\text { EXPANSÃO }\end{array}$} & \multicolumn{2}{|c|}{$\begin{array}{c}\text { (2) } \\
\text { PÓS- } \\
\text { EXPANSÃO } \\
\end{array}$} & \multicolumn{2}{|c|}{$\begin{array}{l}\text { Diferença } \\
\text { (2) - (1) }\end{array}$} & \multirow[t]{2}{*}{$\begin{array}{l}\text { Signifi- } \\
\text { cância }\end{array}$} \\
\hline $\begin{array}{c}\text { Tipo } \\
\text { Hyrax }\end{array}$ & $\begin{array}{l}\mathrm{N} \\
21\end{array}$ & $X$ & D.P. & $X$ & D.P. & $X$ & D.P. & \\
\hline \multicolumn{9}{|c|}{ Variáveis } \\
\hline \multicolumn{2}{|c|}{$\mathrm{NC}-\mathrm{CN}$} & 29,38 & 3,02 & 31,23 & 2,64 & 1,85 & 1,27 & $*$ \\
\hline \multicolumn{2}{|c|}{ JL-JR } & 61,85 & 3,02 & 64,00 & 3,16 & 2,14 & 1,38 & $*$ \\
\hline \multicolumn{2}{|c|}{ RSR } & 48,30 & 3,70 & 52,54 & 3,83 & 4,23 & 2,91 & $*$ \\
\hline \multicolumn{2}{|c|}{$\mathrm{CSC}$} & 55,57 & 2,83 & 61,40 & 3,19 & 5,83 & 1,78 & $*$ \\
\hline \multicolumn{2}{|c|}{ CIC } & 57,92 & 3,19 & 58,92 & 3,29 & 1,00 & 1,22 & $*$ \\
\hline \multicolumn{2}{|c|}{ A6-JL } & 8,09 & 1,86 & 6,02 & 1,74 & $-2,07$ & 1,31 & $*$ \\
\hline \multicolumn{2}{|c|}{ 6A-JR } & 7,40 & 1,44 & 5,59 & 1,79 & $-1,81$ & 1,10 & $*$ \\
\hline \multicolumn{2}{|c|}{ 6R.Z } & 78,66 & 4,62 & 75,35 & 6,11 & $-3,31$ & 5,57 & $\mathrm{~ns}$ \\
\hline \multicolumn{2}{|c|}{ 6L.Z } & 69,38 & 3,77 & 66,64 & 4,66 & $-2,73$ & 6,15 & ns \\
\hline \multicolumn{2}{|c|}{ AI-IA } & 6,57 & 1,46 & 9,90 & 2,67 & 3,33 & 2,59 & $*$ \\
\hline \multicolumn{2}{|c|}{ IM-MI } & 0,00 & 0,00 & 3,23 & 1,35 & 3,23 & 1,35 & $*$ \\
\hline \multicolumn{2}{|c|}{ A1R.Z } & 87,04 & 3,65 & 89,04 & 4,82 & 2,00 & 5,05 & ns \\
\hline \multicolumn{2}{|c|}{ A1L.Z } & 86,61 & 5,31 & 85,11 & 6,23 & $-1,50$ & 3,71 & ns \\
\hline \multicolumn{2}{|c|}{ SOBREM. } & 0,90 & 2,21 & $-0,19$ & 1,59 & $-1,09$ & 1,72 & $*$ \\
\hline \multicolumn{2}{|c|}{ AFAI } & 64,09 & 4,74 & 66,52 & 4,52 & 2,42 & 1,43 & $*$ \\
\hline
\end{tabular}

* - estatisticamente significante $(\mathrm{p}<0,05)$

ns - estatisticamente não significante 
TABELA 5.8 : Significância estatística, médias (X) e desvios-padrão (D.P.) das medidas cefalométricas e das diferenças entre as fases pósexpansão (2) e pós-contenção (3), observadas no Grupo II (aparelhos expansores dentossuportados - tipo Hyrax).

\begin{tabular}{|c|c|c|c|c|c|c|c|c|}
\hline \multicolumn{2}{|c|}{ FASE } & \multicolumn{2}{|c|}{$\begin{array}{c}\text { (2) } \\
\text { PÓS- } \\
\text { EXPANSÃO } \\
\end{array}$} & \multicolumn{2}{|c|}{$\begin{array}{c}\text { (3) } \\
\text { PÓS- } \\
\text { CONTENÇÃO } \\
\end{array}$} & \multicolumn{2}{|c|}{$\begin{array}{c}\text { Diferença } \\
\text { (3) - (2) }\end{array}$} & \multirow[t]{2}{*}{$\begin{array}{l}\text { Signifi- } \\
\text { cância }\end{array}$} \\
\hline $\begin{array}{c}\text { Tipo } \\
\text { Hyrax }\end{array}$ & $\begin{array}{l}\mathrm{N} \\
21 \\
\end{array}$ & $X$ & D.P. & $X$ & D.P. & $X$ & D.P. & \\
\hline \multicolumn{9}{|c|}{ Variáveis } \\
\hline \multicolumn{2}{|c|}{$\mathrm{NC}-\mathrm{CN}$} & 31,23 & 2,64 & 31,73 & 2,42 & 0,50 & 1,00 & $\mathrm{~ns}$ \\
\hline \multicolumn{2}{|c|}{ JL-JR } & 64,00 & 3,16 & 63,83 & 2,79 & $-0,16$ & 1,01 & ns \\
\hline \multicolumn{2}{|c|}{ RSR } & 52,54 & 3,83 & 53,28 & 3,52 & 0,73 & 2,41 & ns \\
\hline \multicolumn{2}{|c|}{$\mathrm{CSC}$} & 61,40 & 3,19 & 61,59 & 3,13 & 0,19 & 1,66 & $\mathrm{~ns}$ \\
\hline \multicolumn{2}{|c|}{ CIC } & 58,92 & 3,29 & 58,80 & 2,73 & $-0,11$ & 1,36 & $\mathrm{~ns}$ \\
\hline \multicolumn{2}{|c|}{ A6-JL } & 6,02 & 1,74 & 5,80 & 2,00 & $-0,21$ & 1,47 & $\mathrm{~ns}$ \\
\hline \multicolumn{2}{|c|}{ 6A-JR } & 5,59 & 1,79 & 5,52 & 1,92 & $-0,07$ & 1,06 & ns \\
\hline \multicolumn{2}{|c|}{ 6R.Z } & 75,35 & 6,11 & 75,71 & 6,43 & 0,35 & 7,55 & ns \\
\hline \multicolumn{2}{|c|}{ 6L.Z } & 66,64 & 4,66 & 67,16 & 3,55 & 0,52 & 4,65 & ns \\
\hline \multicolumn{2}{|c|}{ AI-IA } & 9,90 & 2,67 & 10,07 & 2,27 & 0,16 & 1,51 & ns \\
\hline \multicolumn{2}{|c|}{ IM-MI } & 3,23 & 1,35 & 0,19 & 0,51 & $-3,04$ & 1,37 & $*$ \\
\hline \multicolumn{2}{|c|}{ A1R.Z } & 89,04 & 4,82 & 92,42 & 4,48 & 3,38 & 4,71 & $*$ \\
\hline \multicolumn{2}{|c|}{ A1L.Z } & 85,11 & 6,23 & 91,52 & 6,07 & 6,40 & 4,84 & $*$ \\
\hline \multicolumn{2}{|c|}{ SOBREM. } & $-0,19$ & 1,59 & 0,88 & 1,17 & 1,07 & 1,35 & $*$ \\
\hline \multicolumn{2}{|c|}{ AFAI } & 66,52 & 4,52 & 65,69 & 5,06 & $-0,83$ & 1,71 & ns \\
\hline
\end{tabular}

* - estatisticamente significante $(\mathrm{p}<0,05)$

ns - estatisticamente não significante 
TABELA 5.9 : Significância estatística, médias (X) e desvios-padrão (D.P.) das medidas cefalométricas e das diferenças entre as fases préexpansão (1) e pós-contenção (3), observadas no Grupo II (aparelhos expansores dentossuportados - tipo Hyrax).

\begin{tabular}{|c|c|c|c|c|c|c|c|c|}
\hline \multicolumn{2}{|c|}{ FASE } & \multicolumn{2}{|c|}{$\begin{array}{c}\text { (1) } \\
\text { PRÉ- } \\
\text { EXPANSÃO } \\
\end{array}$} & \multicolumn{2}{|c|}{$\begin{array}{c}\text { (3) } \\
\text { PÓS- } \\
\text { CONTENÇÃO } \\
\end{array}$} & \multicolumn{2}{|c|}{$\begin{array}{l}\text { Diferença } \\
\text { (3) - (1) }\end{array}$} & \multirow[t]{2}{*}{$\begin{array}{l}\text { Signifi- } \\
\text { cância }\end{array}$} \\
\hline $\begin{array}{c}\text { Tipo } \\
\text { Hyrax }\end{array}$ & $\begin{array}{l}\mathrm{N} \\
21 \\
\end{array}$ & $\mathrm{X}$ & D.P. & X & D.P. & $X$ & D.P. & \\
\hline \multicolumn{9}{|c|}{ Variáveis } \\
\hline \multicolumn{2}{|c|}{$\mathrm{NC}-\mathrm{CN}$} & 29,38 & 3,02 & 31,73 & 2,42 & 2,35 & 1,35 & $*$ \\
\hline \multicolumn{2}{|c|}{ JL-JR } & 61,85 & 3,02 & 63,83 & 2,79 & 1,97 & 1,48 & $*$ \\
\hline \multicolumn{2}{|c|}{ RSR } & 48,30 & 3,70 & 53,28 & 3,52 & 4,97 & 3,11 & $*$ \\
\hline \multicolumn{2}{|c|}{$\mathrm{CSC}$} & 55,57 & 2,83 & 61,59 & 3,13 & 6,02 & 2,01 & $*$ \\
\hline \multicolumn{2}{|c|}{ CIC } & 57,92 & 3,19 & 58,8 & 2,73 & 0,88 & 1,12 & $*$ \\
\hline \multicolumn{2}{|c|}{ A6-JL } & 8,09 & 1,86 & 5,80 & 2,00 & $-2,28$ & 1,49 & $*$ \\
\hline \multicolumn{2}{|c|}{ 6A-JR } & 7,40 & 1,44 & 5,52 & 1,92 & $-1,88$ & 1,25 & $*$ \\
\hline \multicolumn{2}{|c|}{ 6R.Z } & 78,66 & 4,62 & 75,71 & 6,43 & $-2,95$ & 5,65 & ns \\
\hline \multicolumn{2}{|c|}{ 6L.Z } & 69,38 & 3,77 & 67,16 & 3,55 & $-2,21$ & 4,64 & ns \\
\hline \multicolumn{2}{|c|}{ AI-IA } & 6,57 & 1,46 & 10,07 & 2,27 & 3,50 & 1,93 & $*$ \\
\hline \multicolumn{2}{|c|}{ IM-MI } & 0,00 & 0,00 & 0,19 & 0,51 & 0,19 & 0,51 & ns \\
\hline \multicolumn{2}{|c|}{ A1R.Z } & 87,04 & 3,65 & 92,42 & 4,48 & 5,38 & 5,32 & * \\
\hline \multicolumn{2}{|c|}{ A1L.Z } & 86,61 & 5,31 & 91,52 & 6,07 & 4,90 & 5,70 & $*$ \\
\hline \multicolumn{2}{|c|}{ SOBREM. } & 0,90 & 2,21 & 0,88 & 1,17 & $-0,02$ & 1,54 & ns \\
\hline \multicolumn{2}{|c|}{ AFAI } & 64,09 & 4,74 & 65,69 & 5,06 & 1,59 & 1,71 & $*$ \\
\hline
\end{tabular}

* - estatisticamente significante $(\mathrm{p}<0,05)$

ns - estatisticamente não significante 
TABELA 5.10 : Significância estatística, médias (X) e desvios-padrão (D.P.) das medidas cefalométricas e das diferenças entre as fases préexpansão (1) e pós-expansão (2), observadas no Grupo III (aparelhos expansores dentossuportados - tipo colado).

\begin{tabular}{|c|c|c|c|c|c|c|c|c|}
\hline \multicolumn{2}{|c|}{ FASE } & \multicolumn{2}{|c|}{$\begin{array}{c}\text { (1) } \\
\text { PRÉ- } \\
\text { EXPANSÃO } \\
\end{array}$} & \multicolumn{2}{|c|}{$\begin{array}{c}\text { (2) } \\
\text { PÓS- } \\
\text { EXPANSÃO } \\
\end{array}$} & \multicolumn{2}{|c|}{$\begin{array}{l}\text { Diferença } \\
\text { (2) - (1) }\end{array}$} & \multirow[t]{2}{*}{$\begin{array}{l}\text { Signifi- } \\
\text { cância }\end{array}$} \\
\hline $\begin{array}{c}\text { Tipo } \\
\text { Colado }\end{array}$ & $\begin{array}{l}\mathrm{N} \\
22 \\
\end{array}$ & $\mathrm{X}$ & D.P. & $X$ & D.P. & $\mathrm{X}$ & D.P. & \\
\hline \multicolumn{9}{|c|}{ Variáveis } \\
\hline \multicolumn{2}{|c|}{$\mathrm{NC}-\mathrm{CN}$} & 27,08 & 2,20 & 28,93 & 1,99 & 1,85 & 0,90 & $*$ \\
\hline \multicolumn{2}{|c|}{ JL-JR } & 60,50 & 2,96 & 63,12 & 2,91 & 2,62 & 1,16 & $*$ \\
\hline \multicolumn{2}{|c|}{ RSR } & 47,20 & 3,77 & 51,74 & 3,99 & 4,54 & 2,14 & $*$ \\
\hline \multicolumn{2}{|c|}{$\mathrm{CSC}$} & 52,44 & 3,35 & 59,11 & 3,16 & 6,67 & 1,81 & $*$ \\
\hline \multicolumn{2}{|c|}{ CIC } & 56,22 & 2,71 & 56,32 & 2,51 & 0,10 & 0,60 & ns \\
\hline \multicolumn{2}{|c|}{ A6-JL } & 8,99 & 1,89 & 6,79 & 1,57 & $-2,2$ & 1,05 & $*$ \\
\hline \multicolumn{2}{|c|}{ 6A-JR } & 8,81 & 2,28 & 6,23 & 2,02 & $-2,58$ & 1,53 & $*$ \\
\hline \multicolumn{2}{|c|}{ 6R.Z } & 79,75 & 3,77 & 72,41 & 5,10 & $-7,34$ & 3,85 & $*$ \\
\hline \multirow{2}{*}{\multicolumn{2}{|c|}{ 6L.Z }} & 84,09 & 4,08 & 76,88 & 3,52 & $-7,2$ & 4,43 & $*$ \\
\hline AI-IA & & 6,57 & 1,40 & 11,08 & 2,06 & 4,51 & 1,35 & $*$ \\
\hline \multicolumn{2}{|c|}{ IM-MI } & 0,43 & 0,69 & 3,46 & 0,77 & 3,02 & 0,66 & $*$ \\
\hline \multicolumn{2}{|c|}{ A1R.Z } & 88,31 & 3,65 & 92,38 & 4,21 & 4,06 & 3,06 & $*$ \\
\hline \multicolumn{2}{|c|}{ A1L.Z } & 86,13 & 3,55 & 89,79 & 5,27 & 3,65 & 3,45 & $*$ \\
\hline \multicolumn{2}{|c|}{ SOBREM. } & 1,35 & 1,96 & - & - & - & - & - \\
\hline \multicolumn{2}{|c|}{ AFAI } & 64,52 & 6,90 & - & - & - & - & - \\
\hline
\end{tabular}

* - estatisticamente significante $(\mathrm{p}<0,05)$

ns - estatisticamente não significante 
TABELA 5.11: Significância estatística, médias (X) e desvios-padrão (D.P.) das medidas cefalométricas e das diferenças entre as fases pósexpansão (2) e pós-contenção (3), observadas no Grupo III (aparelhos expansores dentossuportados - tipo colado).

\begin{tabular}{|c|c|c|c|c|c|c|c|c|}
\hline \multicolumn{2}{|c|}{ FASE } & \multicolumn{2}{|c|}{$\begin{array}{c}(2) \\
\text { PÓS- } \\
\text { EXPANSÃo }\end{array}$} & \multicolumn{2}{|c|}{$\begin{array}{c}\text { (3) } \\
\text { PÓS- } \\
\text { CONTENÇÃO } \\
\end{array}$} & \multicolumn{2}{|c|}{$\begin{array}{l}\text { Diferença } \\
\text { (3) - (2) }\end{array}$} & \multirow[t]{2}{*}{$\begin{array}{l}\text { Signifi- } \\
\text { cância }\end{array}$} \\
\hline $\begin{array}{c}\text { Tipo } \\
\text { Colado }\end{array}$ & $\begin{array}{l}\mathrm{N} \\
22 \\
\end{array}$ & X & D.P. & X & D.P. & $\mathrm{X}$ & D.P. & \\
\hline \multicolumn{9}{|c|}{ Variáveis } \\
\hline $\mathrm{NC}-\mathrm{Cl}$ & & 28,93 & 1,99 & 28,85 & 1,96 & $-0,08$ & 0,27 & ns \\
\hline JL-JR & & 63,12 & 2,91 & 63,20 & 3,03 & 0,07 & 1,10 & ns \\
\hline RSR & & 51,74 & 3,99 & 53,04 & 3,84 & 1,29 & 1,04 & $*$ \\
\hline CSC & & 59,11 & 3,16 & 59,84 & 2,99 & 0,72 & 1,09 & ns \\
\hline CIC & & 56,32 & 2,51 & 56,36 & 2,81 & 0,04 & 0,68 & ns \\
\hline A6-JL & & 6,79 & 1,57 & 6,31 & 1,87 & $-0,48$ & 1,06 & ns \\
\hline 6A-JR & & 6,23 & 2,02 & 5,81 & 1,94 & $-0,42$ & 1,04 & $\mathrm{~ns}$ \\
\hline 6R.Z & & 72,41 & 5,10 & 72,93 & 4,27 & 0,52 & 4,99 & ns \\
\hline 6L.Z & & 76,88 & 3,52 & 79,63 & 4,09 & 2,75 & 4,31 & * \\
\hline AI-IA & & 11,08 & 2,06 & 9,57 & 1,81 & $-1,51$ & 2,00 & $*$ \\
\hline IM-M & & 3,46 & 0,77 & 0,20 & 0,38 & $-3,26$ & 0,63 & $*$ \\
\hline A1R.Z & & 92,38 & 4,21 & 93,93 & 4,39 & 1,54 & 4,32 & ns \\
\hline A1L.Z & & 89,79 & 5,27 & 91,81 & 4,09 & 2,02 & 3,40 & $*$ \\
\hline SOBRE & & - & - & 0,98 & 1,73 & - & - & - \\
\hline AFAI & & - & - & 65,60 & 6,92 & - & - & - \\
\hline
\end{tabular}

* - estatisticamente significante $(\mathrm{p}<0,05)$

ns - estatisticamente não significante 
TABELA 5.12 : Significância estatística, médias (X) e desvios-padrão (D.P.) das medidas cefalométricas e das diferenças entre as fases préexpansão (1) e pós-contenção (3), observadas no Grupo III (aparelhos expansores dentossuportados - tipo colado).

\begin{tabular}{|c|c|c|c|c|c|c|c|c|}
\hline \multicolumn{2}{|c|}{ FASE } & \multicolumn{2}{|c|}{$\begin{array}{c}(1) \\
\text { PRÉ- } \\
\text { EXPANSÃo }\end{array}$} & \multicolumn{2}{|c|}{$\begin{array}{c}\text { (3) } \\
\text { PÓS- } \\
\text { CONTENÇÃO } \\
\end{array}$} & \multicolumn{2}{|c|}{$\begin{array}{c}\text { Diferença } \\
\text { (3) - (1) }\end{array}$} & \multirow[t]{2}{*}{$\begin{array}{l}\text { Signifi- } \\
\text { cância }\end{array}$} \\
\hline $\begin{array}{c}\text { Tipo } \\
\text { Colado }\end{array}$ & $\begin{array}{l}\mathrm{N} \\
22 \\
\end{array}$ & X & D.P. & $X$ & D.P. & $\mathrm{X}$ & D.P. & \\
\hline \multicolumn{9}{|c|}{ Variáveis } \\
\hline $\mathrm{NC}-\mathrm{Cl}$ & & 27,08 & 2,20 & 28,85 & 1,96 & 1,76 & 0,83 & $*$ \\
\hline JL-JR & & 60,50 & 2,96 & 63,20 & 3,03 & 2,69 & 1,37 & $*$ \\
\hline RSR & & 47,20 & 3,77 & 53,04 & 3,84 & 5,84 & 1,95 & $*$ \\
\hline $\mathrm{CSC}$ & & 52,44 & 3,35 & 59,84 & 2,99 & 7,40 & 1,82 & $*$ \\
\hline CIC & & 56,22 & 2,71 & 56,36 & 2,81 & 0,14 & 0,77 & ns \\
\hline A6-JI & & 8,99 & 1,89 & 6,31 & 1,87 & $-2,68$ & 1,28 & $*$ \\
\hline 6A-JF & & 8,81 & 2,28 & 5,81 & 1,94 & $-3,01$ & 1,53 & $*$ \\
\hline $6 \mathrm{R} . Z$ & & 79,75 & 3,77 & 72,93 & 4,27 & $-6,81$ & 4,71 & $*$ \\
\hline 6L.Z & & 84,09 & 4,08 & 79,63 & 4,09 & $-4,45$ & 3,99 & $*$ \\
\hline AI-IA & & 6,57 & 1,40 & 9,57 & 1,81 & 3,00 & 1,42 & $*$ \\
\hline IM-M & & 0,43 & 0,69 & 0,20 & 0,38 & $-0,23$ & 0,43 & ns \\
\hline A1R.Z & & 88,31 & 3,65 & 93,93 & 4,39 & 5,61 & 3,17 & $*$ \\
\hline A1L.Z & & 86,13 & 3,55 & 91,81 & 4,09 & 5,68 & 2,51 & $*$ \\
\hline SOBRE & & 1,35 & 1,96 & 0,98 & 1,73 & $-0,37$ & 1,74 & ns \\
\hline AFAI & & 64,52 & 6,90 & 65,60 & 6,92 & 1,07 & 2,74 & ns \\
\hline
\end{tabular}

* - estatisticamente significante $(\mathrm{p}<0,05)$

ns - estatisticamente não significante 
TABELA 5.13 : Médias (X), desvios-padrão (D.P.) das diferenças das medidas cefalométricas analisadas nas fases pré-expansão (1) e pósexpansão (2), valor de "F", de "p" e a significância estatística da análise de variância (ANOVA) aplicada na comparação dos três grupos.

\begin{tabular}{|c|c|c|c|c|c|c|c|c|}
\hline Fase $2-1$ & \multicolumn{2}{|c|}{$\begin{array}{l}\text { HAAS } \\
\mathbf{N}=\mathbf{2 0}\end{array}$} & \multicolumn{2}{|c|}{$\begin{array}{c}\text { HYRAX } \\
\mathbf{N}=\mathbf{2 1}\end{array}$} & \multicolumn{2}{|c|}{$\begin{array}{c}\text { COLADO } \\
\mathbf{N}=\mathbf{2 2}\end{array}$} & \multirow[t]{2}{*}{$\mathbf{F}$} & \multirow[t]{2}{*}{ p } \\
\hline Variáveis & $\bar{X}$ & D.P. & $\bar{X}$ & D.P. & $\bar{X}$ & D.P. & & \\
\hline $\mathrm{NC}-\mathrm{CN}$ & 1,92 & 1,25 & 1,85 & 1,27 & 1,85 & 0,90 & 0,02 & $0,973 \mathrm{~ns}$ \\
\hline JL-JR & 2,17 & 1,64 & 2,14 & 1,38 & 2,62 & 1,16 & 0,78 & $0,462 \mathrm{~ns}$ \\
\hline RSR & 4,47 & 2,58 & 4,23 & 2,91 & 4,54 & 2,14 & 0,08 & $0,919 \mathrm{~ns}$ \\
\hline $\mathrm{CSC}$ & 4,97 & 3,28 & 5,83 & 1,78 & 6,67 & 1,81 & 2,69 & $0,075 \mathrm{~ns}$ \\
\hline CIC & 0,60 & 1,51 & 1,00 & 1,22 & 0,10 & 0,60 & 3,22 & $0,046 *$ \\
\hline A6-JL & $-1,70$ & 1,55 & $-2,07$ & 1,31 & $-2,2$ & 1,05 & 0,80 & $0,451 \mathrm{~ns}$ \\
\hline 6A-JR & $-1,77$ & 1,69 & $-1,81$ & 1,1 & $-2,58$ & 1,53 & 2,10 & $0,130 \mathrm{~ns}$ \\
\hline 6R.Z & $-4,20$ & 7,31 & $-3,31$ & 5,57 & $-7,34$ & 3,85 & 2,97 & $0,058 \mathrm{~ns}$ \\
\hline 6L.Z & $-1,07$ & 6,07 & $-2,73$ & 6,15 & $-7,20$ & 4,43 & 6,84 & $0,002 *$ \\
\hline AI-IA & 3,40 & 1,93 & 3,33 & 2,59 & 4,51 & 1,35 & 2,29 & $0,109 \mathrm{~ns}$ \\
\hline IM-MI & 2,75 & 1,01 & 3,23 & 1,35 & 3,02 & 0,66 & 1,11 & $0,333 \mathrm{~ns}$ \\
\hline A1R.Z & 0,17 & 4,31 & 2,00 & 5,05 & 4,06 & 3,06 & 4,50 & $0,015 *$ \\
\hline A1L.Z & 2,60 & 4,39 & $-1,5$ & 3,71 & 3,65 & 3,45 & 10,57 & $0,000 *$ \\
\hline SOBR. & $-2,02$ & 1,09 & $-1,09$ & 1,72 & - & - & 4,20 & $0,469 *$ \\
\hline AFAI & 2,65 & 1,49 & 2,42 & 1,43 & - & - & 0,23 & $0,631 \mathrm{~ns}$ \\
\hline
\end{tabular}

* - estatisticamente significante $(\mathrm{p}<0,05)$

ns - estatisticamente não significante 
TABELA 5.14 : Médias (X), desvios-padrão (D.P.) das diferenças das medidas cefalométricas analisadas nas fases pós-expansão (2) e póscontenção (3), valor de "F", de "p" e a significância estatística da análise de variância (ANOVA) aplicada na comparação dos três grupos.

\begin{tabular}{c|c|c|c|c|c|c|c|c}
\hline \multirow{2}{*}{ Fase 3-2 } & \multicolumn{2}{|c|}{$\begin{array}{c}\text { HAAS } \\
\text { N= 20 }\end{array}$} & \multicolumn{2}{c|}{$\begin{array}{c}\text { HYRAX } \\
\text { N=21 }\end{array}$} & \multicolumn{2}{c|}{$\begin{array}{c}\text { COLADO } \\
\mathbf{N}=\mathbf{2 2}\end{array}$} & F & P \\
\hline Variáveis & $\mathbf{X}$ & $\mathbf{D . P .}$ & $\mathbf{X}$ & $\mathbf{D . P .}$ & $\mathbf{X}$ & $\mathbf{D . P .}$ & & \\
\hline NC-CN & 0,2 & 1,19 & 0,50 & 1,00 & $-0,08$ & 0,27 & 2,26 & $0,112 \mathrm{~ns}$ \\
\hline JL-JR & $-0,47$ & 1,08 & $-0,16$ & 1,01 & 0,07 & 1,10 & 1,37 & $0,260 \mathrm{~ns}$ \\
\hline RSR & 0,05 & 2,99 & 0,73 & 2,41 & 1,29 & 1,04 & 1,57 & $0,215 \mathrm{~ns}$ \\
\hline CSC & 0,90 & 3,13 & 0,19 & 1,66 & 0,72 & 1,09 & 0,63 & $0,531 \mathrm{~ns}$ \\
\hline CIC & 1,10 & 2,12 & $-0,11$ & 1,36 & 0,04 & 0,68 & 4,03 & $0,022 *$ \\
\hline A6-JL & 0,00 & 1,13 & $-0,21$ & 1,47 & $-0,48$ & 1,06 & 0,79 & $0,454 \mathrm{~ns}$ \\
\hline 6A-JR & $-0,27$ & 1,51 & $-0,07$ & 1,06 & $-0,42$ & 1,04 & 0,44 & $0,640 \mathrm{~ns}$ \\
\hline 6R.Z & $-1,20$ & 9,00 & 0,35 & 7,55 & 0,52 & 4,99 & 0,34 & $0,708 \mathrm{~ns}$ \\
\hline 6L.Z & $-1,47$ & 6,98 & 0,52 & 4,65 & 2,75 & 4,31 & 3,21 & $0,047 * 2$, \\
\hline AI-IA & $-0,72$ & 1,56 & 0,16 & 1,51 & $-1,51$ & 2,00 & 5,11 & $0,008 *$ \\
\hline IM-MI & $-2,60$ & 1,18 & $-3,04$ & 1,37 & $-3,26$ & 0,63 & 1,94 & $0,151 \mathrm{~ns}$ \\
\hline A1R.Z & 2,55 & 6,17 & 3,38 & 4,71 & 1,54 & 4,32 & 0,69 & $0,501 \mathrm{~ns}$ \\
\hline A1L.Z & 1,32 & 5,88 & 6,40 & 4,84 & 2,02 & 3,40 & 6,91 & $0,001 *$ \\
\hline SOBR. & 1,70 & 0,97 & 1,07 & 1,35 & - & - & 2,87 & $0,097 \mathrm{~ns}$ \\
\hline AFAI & $-0,55$ & 1,35 & $-0,83$ & 1,71 & - & - & 0,34 & $0,561 \mathrm{~ns}$ \\
\hline
\end{tabular}

* - estatisticamente significante $(\mathrm{p}<0,05)$

ns - estatisticamente não significante 
TABELA 5.15 : Médias (X), desvios-padrão (D.P.) das diferenças das medidas cefalométricas analisadas nas fases pré-expansão (1) e póscontenção (3), valor de "F", de "p" e a significância estatística da análise de variância (ANOVA) aplicada na comparação dos três grupos.

\begin{tabular}{|c|c|c|c|c|c|c|c|c|}
\hline \multirow{2}{*}{$\begin{array}{c}\text { Fase 3-1 } \\
\text { Variáveis }\end{array}$} & \multicolumn{2}{|c|}{$\begin{array}{l}\text { HAAS } \\
\mathbf{N}=\mathbf{2 0}\end{array}$} & \multicolumn{2}{|c|}{$\begin{array}{c}\text { HYRAX } \\
\mathbf{N}=\mathbf{2 1}\end{array}$} & \multicolumn{2}{|c|}{$\begin{array}{c}\text { COLADO } \\
\mathbf{N}=\mathbf{2 2}\end{array}$} & \multirow[t]{2}{*}{$\mathbf{F}$} & \multirow[t]{2}{*}{$\mathbf{P}$} \\
\hline & $\bar{X}$ & D.P. & $\bar{X}$ & D.P. & $\bar{X}$ & D.P. & & \\
\hline $\mathrm{NC}-\mathrm{CN}$ & 2,12 & 1,12 & 2,35 & 1,35 & 1,76 & 0,83 & 1,54 & $0,222 \mathrm{~ns}$ \\
\hline JL-JR & 1,70 & 1,33 & 1,97 & 1,48 & 2,69 & 1,37 & 2,86 & $0,065 \mathrm{~ns}$ \\
\hline RSR & 4,52 & 3,49 & 4,97 & 3,11 & 5,84 & 1,95 & 1,12 & $0,332 \mathrm{~ns}$ \\
\hline CSC & 5,87 & 2,15 & 6,02 & 2,01 & 7,40 & 1,82 & 3,81 & 0,027 * \\
\hline $\mathrm{CIC}$ & 1,70 & 2,38 & 0,88 & 1,12 & 0,14 & 0,77 & 5,22 & $0,008 *$ \\
\hline A6-JL & $-1,70$ & 1,78 & $-2,28$ & 1,49 & $-2,68$ & 1,28 & 2,18 & $0,121 \mathrm{~ns}$ \\
\hline 6A-JR & $-2,05$ & 1,30 & $-1,88$ & 1,25 & $-3,01$ & 1,53 & 4,23 & $0,019 *$ \\
\hline 6R.Z & $-5,40$ & 5,41 & $-2,95$ & 5,65 & $-6,81$ & 4,71 & 2,95 & $0,059 \mathrm{~ns}$ \\
\hline 6L.Z & $-2,55$ & 4,87 & $-2,21$ & 4,64 & $-4,45$ & 3,99 & 1,54 & $0,221 \mathrm{~ns}$ \\
\hline AI-IA & 2,67 & 1,94 & 3,50 & 1,93 & 3,00 & 1,42 & 1,12 & $0,332 \mathrm{~ns}$ \\
\hline IM-MI & 0,15 & 0,67 & 0,19 & 0,51 & $-0,23$ & 0,43 & 4,04 & $0,022 *$ \\
\hline A1R.Z & 2,72 & 4,84 & 5,38 & 5,32 & 5,61 & 3,17 & 2,59 & $0,083 \mathrm{~ns}$ \\
\hline A1L.Z & 3,92 & 6,53 & 4,90 & 5,70 & 5,68 & 2,51 & 0,60 & $0,547 \mathrm{~ns}$ \\
\hline SOBR. & $-0,32$ & 1,33 & $-0,02$ & 1,54 & $-0,37$ & 1,74 & 0,31 & $0,732 \mathrm{~ns}$ \\
\hline AFAI & 2,10 & 2,07 & 1,59 & 1,71 & 1,07 & 2,74 & 1,11 & $0,333 \mathrm{~ns}$ \\
\hline
\end{tabular}

* - estatisticamente significante $(\mathrm{p}<0,05)$

ns - estatisticamente não significante 
TABELA 5.16 : Comparações entre os três grupos, com as médias e os valores de "p", realizadas com o teste de Tukey, para a variável CSC pré-expansão (CSC1) até pós-contenção (CSC3), que apresentou diferença estatisticamente significante na ANOVA.

\begin{tabular}{c|c}
\hline COMPARAÇÕES - VARIÁVEL $($ CSC3 $)-($ CSC1 $)$ & P \\
\hline HAAS $(\mathrm{x}=5,87)$ X HYRAX $(\mathrm{x}=6,02)$ & $0,969 \mathrm{~ns}$ \\
\hline HAAS $(\mathrm{x}=5,87)$ X COLADO $(\mathrm{x}=7,40)$ & $0,041 *$ \\
\hline $\operatorname{HYRAX}(\mathrm{x}=6,02) \times \operatorname{COLADO}(\mathrm{x}=7,40)$ & $0,068 \mathrm{~ns}$ \\
\hline
\end{tabular}

* - estatisticamente significante $(\mathrm{p}<0,05)$

ns - estatisticamente não significante

$\mathrm{x}$ - média 
TABELA 5.17 : Comparações entre os três grupos, com as médias e os valores de p, realizadas com o teste de Tukey, para a variável CIC préexpansão (CIC1) até pós-expansão (CIC2), que apresentou diferença estatisticamente significante na ANOVA.

\begin{tabular}{c|c}
\hline COMPARAÇÕES - VARIÁVEL $(\mathbf{C I C})-(\mathbf{C I C} 1)$ & $\mathbf{P}$ \\
\hline HAAS $(\mathrm{x}=0,60) \mathrm{X} \operatorname{HYRAX}(\mathrm{x}=1,00)$ & $0,518 \mathrm{~ns}$ \\
\hline $\operatorname{HAAS}(\mathrm{x}=0,60) \mathrm{X} \operatorname{COLADO}(\mathrm{x}=0,10)$ & $0,352 \mathrm{~ns}$ \\
\hline $\operatorname{HYRAX}(\mathrm{x}=1,00) \times \operatorname{COLADO}(\mathrm{x}=0,10)$ & $0,036 *$ \\
\hline
\end{tabular}

* - estatisticamente significante $(\mathrm{p}<0,05)$

ns - estatisticamente não significante

X - média 
TABELA 5.18 : Comparações entre os três grupos, com as médias e os valores de $\mathrm{p}$, realizadas com o teste de Tukey, para a variável CIC pós-expansão (CIC2) até pós-contenção (CIC3), que apresentou diferença estatisticamente significante na ANOVA.

\begin{tabular}{c|c}
\hline COMPARAÇÕES - VARIÁVEL $(\mathbf{C I C 3})-(\mathbf{C I C})$ & $\mathbf{P}$ \\
\hline HAAS $(\mathrm{x}=1,10)$ X HYRAX $(\mathrm{x}=-0,11)$ & $0,029 *$ \\
\hline HAAS $(\mathrm{x}=1,10) \mathrm{X} \operatorname{COLADO}(\mathrm{x}=0,04)$ & $0,063 \mathrm{~ns}$ \\
\hline $\operatorname{HYRAX}(\mathrm{x}=-0,11) \mathrm{X} \operatorname{COLADO}(\mathrm{x}=0,04)$ & $0,934 \mathrm{~ns}$ \\
\hline
\end{tabular}

* - estatisticamente significante $(\mathrm{p}<0,05)$

ns - estatisticamente não significante

$\mathrm{x}$ - média 
TABELA 5.19 : Comparações entre os três grupos, com as médias e os valores de p, realizadas com o teste de Tukey, para a variável CIC préexpansão (CIC1) até pós-contenção (CIC3), que apresentou diferença estatisticamente significante na ANOVA.

\begin{tabular}{c|c}
\hline COMPARAÇÕES - VARIÁVEL $(\mathbf{C I C 3})-(\mathbf{C I C} 1)$ & $\mathbf{P}$ \\
\hline HAAS $(\mathrm{x}=1,70)$ X HYRAX $(\mathrm{x}=0,88)$ & $0,221 \mathrm{~ns}$ \\
\hline $\operatorname{HAAS}(\mathrm{x}=1,70) \mathrm{X} \operatorname{COLADO}(\mathrm{x}=0,14)$ & $0,005 *$ \\
\hline $\operatorname{HYRAX}(\mathrm{x}=0,88) \times \operatorname{COLADO}(\mathrm{x}=0,14)$ & $0,273 \mathrm{~ns}$ \\
\hline
\end{tabular}

* - estatisticamente significante $(\mathrm{p}<0,05)$

ns - estatisticamente não significante

$\mathrm{x}$ - média 
TABELA 5.20 : Comparações entre os três grupos, com as médias e os valores de $\mathrm{p}$, realizadas com o teste de Tukey, para a variável 6A-JR pré-expansão (6A-JR1) até pós-contenção (6A-JR3), que apresentou diferença estatisticamente significante na ANOVA .

\begin{tabular}{c|c}
\hline COMPARAÇÕES - VARIÁVEL (6A-JR3) - (6A-JR1) & P \\
\hline HAAS $(\mathrm{x}=-2,05)$ X HYRAX $(\mathrm{x}=-1,88)$ & $0,918 \mathrm{~ns}$ \\
\hline $\operatorname{HAAS}(\mathrm{x}=-2,05)$ X COLADO $(\mathrm{x}=-3,00)$ & $0,069 \mathrm{~ns}$ \\
\hline $\operatorname{HYRAX}(\mathrm{x}=-1,88)$ X COLADO $(\mathrm{x}=-3,00)$ & $0,024 *$ \\
\hline
\end{tabular}

* - estatisticamente significante $(\mathrm{p}<0,05)$

ns - estatisticamente não significante

$\mathrm{x}$ - média 
TABELA 5.21 : Comparações entre os três grupos, com as médias e os valores de $\mathrm{p}$, realizadas com o teste de Tukey, para a variável 6L.Z préexpansão (6L.Z1) até pós-expansão (6L.Z2), que apresentou diferença estatisticamente significante na ANOVA.

\begin{tabular}{c|c}
\hline COMPARAÇÕES - VARIÁVEL (6L.Z2) $-(6 \mathbf{6} . Z 1)$ & $\mathbf{P}$ \\
\hline HAAS $(\mathrm{x}=-1,07)$ X HYRAX $(\mathrm{x}=-2,73)$ & $0,609 \mathrm{~ns}$ \\
\hline HAAS $(\mathrm{x}=-1,07)$ X COLADO $(\mathrm{x}=-7,20)$ & $0,002 *$ \\
\hline $\operatorname{HYRAX}(\mathrm{x}=-2,73)$ X COLADO $(\mathrm{x}=-7,20)$ & $0,029 *$ \\
\hline
\end{tabular}

* - estatisticamente significante $(\mathrm{p}<0,05)$

ns - estatisticamente não significante

x - média 
TABELA 5.22 : Comparações entre os três grupos, com as médias e os valores de $\mathrm{p}$, realizadas com o teste de Tukey, para a variável 6L.Z pós-expansão (6L.Z2) até pós-contenção (6L.Z3), que apresentou diferença estatisticamente significante na ANOVA .

\begin{tabular}{c|c}
\hline COMPARAÇÕES - VARIÁVEL (6L.Z3) $-(6 \mathbf{6} . Z 2)$ & $\mathbf{P}$ \\
\hline HAAS $(\mathrm{x}=-1,47)$ X HYRAX $(\mathrm{x}=0,52)$ & $0,467 \mathrm{~ns}$ \\
\hline HAAS $(\mathrm{x}=-1,47)$ X COLADO $(\mathrm{x}=2,75)$ & $0,036 *$ \\
\hline $\operatorname{HYRAX}(\mathrm{x}=0,52) \times \operatorname{COLADO}(\mathrm{x}=2,75)$ & $0,373 \mathrm{~ns}$ \\
\hline
\end{tabular}

* - estatisticamente significante $(\mathrm{p}<0,05)$

ns - estatisticamente não significante

x - média 
TABELA 5.23 : Comparações entre os três grupos, com as médias e os valores de $\mathrm{p}$, realizadas com o teste de Tukey, para a variável AI-IA pós-expansão (AI-IA2) até pós-contenção (AI-IA3), que apresentou diferença estatisticamente significante na ANOVA.

\begin{tabular}{c|c}
\hline COMPARAÇÕES - VARIÁVEL (AI-IA3) $-($ AI-IA2) & P \\
\hline HAAS $(\mathrm{x}=-0,72)$ X HYRAX $(\mathrm{x}=0,16)$ & $0,228 \mathrm{~ns}$ \\
\hline $\operatorname{HAAS}(\mathrm{x}=-0,72)$ X COLADO $(\mathrm{x}=-1,50)$ & $0,308 \mathrm{~ns}$ \\
\hline $\operatorname{HYRAX}(\mathrm{x}=0,16) \times \operatorname{COLADO}(\mathrm{x}=-1,50)$ & $0,006 *$ \\
\hline
\end{tabular}

$*$ - estatisticamente significante $(\mathrm{p}<0,05)$

ns - estatisticamente não significante

$\mathrm{x}$ - média 
TABELA 5.24 : Comparações entre os três grupos, com as médias e os valores de $\mathrm{p}$, realizadas com o teste de Tukey, para a variável IM-MI pré-expansão (IM-MI1) até pós-contenção (IM-MI3), que apresentou diferença estatisticamente significante na ANOVA.

\begin{tabular}{c|c}
\hline COMPARAÇÕES - VARIÁVEL (IM-MI3) $-($ IM-MI1) & P \\
\hline HAAS $(\mathrm{x}=0,15)$ X HYRAX $(\mathrm{x}=0,19)$ & $0,969 \mathrm{~ns}$ \\
\hline HAAS $(\mathrm{x}=0,15)$ X COLADO $(\mathrm{x}=-0,23)$ & $0,063 \mathrm{~ns}$ \\
\hline $\operatorname{HYRAX}(\mathrm{x}=0,19) \mathrm{X} \operatorname{COLADO}(\mathrm{x}=-0,23)$ & $0,033 *$ \\
\hline
\end{tabular}

* - estatisticamente significante $(\mathrm{p}<0,05)$

ns - estatisticamente não significante

$\mathrm{x}$ - média 
TABELA 5.25 : Comparações entre os três grupos, com as médias e os valores de $\mathrm{p}$, realizadas com o teste de Tukey, para a variável A1R.Z pré-expansão (A1R.Z1) até pós-expansão (A1R.Z2), que apresentou diferença estatisticamente significante na ANOVA.

\begin{tabular}{c|c}
\hline COMPARAÇÕES - VARIÁ VEL $(\mathbf{A} 1 \mathbf{R} . Z 2)-(\mathbf{A} 1 \mathbf{R} . Z 1)$ & $\mathbf{P}$ \\
\hline HAAS $(\mathrm{x}=0,17)$ X $\operatorname{HYRAX}(\mathrm{x}=2,00)$ & $0,353 \mathrm{~ns}$ \\
\hline HAAS $(\mathrm{x}=0,17) \mathrm{X} \operatorname{COLADO}(\mathrm{x}=4,06)$ & $0,011 *$ \\
\hline $\operatorname{HYRAX}(\mathrm{x}=2,00) \times \operatorname{COLADO}(\mathrm{x}=4,06)$ & $0,248 \mathrm{~ns}$ \\
\hline
\end{tabular}

* - estatisticamente significante $(\mathrm{p}<0,05)$

ns - estatisticamente não significante

$\mathrm{x}$ - média 
TABELA 5.26 : Comparações entre os três grupos, com as médias e os valores de p, realizadas com o teste de Tukey, para a variável A1L.Z pré-expansão (A1L.Z1) até pós-expansão (A1L.Z2), que apresentou diferença estatisticamente significante na ANOVA.

\begin{tabular}{c|c}
\hline COMPARAÇÕES - VARIÁVEL (A1L.Z2) $-(\mathbf{A} 1 \mathbf{L} . Z 1)$ & P \\
\hline HAAS $(\mathrm{x}=2,60)$ X HYRAX $(\mathrm{x}=-1,50)$ & $0,003 *$ \\
\hline HAAS $(\mathrm{x}=2,60)$ X COLADO $(\mathrm{x}=3,65)$ & $0,649 \mathrm{~ns}$ \\
\hline $\operatorname{HYRAX}(\mathrm{x}=-1,50) \mathrm{X} \operatorname{COLADO}(\mathrm{x}=3,65)$ & $0,000 *$ \\
\hline
\end{tabular}

$*$ - estatisticamente significante $(\mathrm{p}<0,05)$

ns - estatisticamente não significante

$\mathrm{x}$ - média 
TABELA 5.27 : Comparações entre os três grupos, com as médias e os valores de $\mathrm{p}$, realizadas com o teste de Tukey, para a variável A1L.Z pós-expansão (A1L.Z2) até pós-contenção (A1L.Z3), que apresentou diferença estatisticamente significante na ANOVA .

\begin{tabular}{c|c}
\hline COMPARAÇÕES - VARIÁVEL (A1L.Z3) $-(\mathbf{A} 1 \mathbf{L} . Z 2)$ & P \\
\hline HAAS $(\mathrm{x}=1,32)$ X $\operatorname{HYRAX}(\mathrm{x}=6,40)$ & $0,003 *$ \\
\hline $\operatorname{HAAS}(\mathrm{x}=1,32) \mathrm{X} \operatorname{COLADO}(\mathrm{x}=2,02)$ & $0,884 \mathrm{~ns}$ \\
\hline $\operatorname{HYRAX}(\mathrm{x}=6,40) \times \operatorname{COLADO}(\mathrm{x}=2,02)$ & $0,010 *$ \\
\hline
\end{tabular}

* - estatisticamente significante $(\mathrm{p}<0,05)$

ns - estatisticamente não significante

X - média 
TABELA 5.28: Análise intra-examinador da precisão do método cefalométrico. Apresentação dos erros casuais (Dahlberg), nos três tempos das radiografias.

\begin{tabular}{c|c|c|c}
\hline VARIÁVEIS & $\begin{array}{c}\text { Erro Casual } \\
\text { Pré-expansão }\end{array}$ & $\begin{array}{c}\text { Erro Casual } \\
\text { Pós-expansão }\end{array}$ & $\begin{array}{c}\text { Erro Casual } \\
\text { Pós-contenção }\end{array}$ \\
\hline NC-CN & 0,28 & 0,40 & 0,51 \\
\hline JL-JR & 0,79 & 0,74 & 0,35 \\
\hline RSR & 0,70 & 1,11 & 0,87 \\
\hline CSC & 0,76 & 0,15 & 0,53 \\
\hline CIC & 0,53 & 0,00 & 0,67 \\
\hline A6-JL & 0,44 & 0,44 & 0,44 \\
\hline 6A-JR & 0,47 & 0,31 & 0,57 \\
\hline 6R.Z & 2,81 & 2,79 & 4,03 \\
\hline 6L.Z & 1,37 & 2,64 & 0,63 \\
\hline AI-IA & 0,51 & 0,67 & 0,31 \\
\hline IM-MI & 0,28 & 0,42 & 0,28 \\
\hline A1R.Z & 1,35 & 1,65 & 1,15 \\
\hline A1L.Z & 2,24 & 1,41 & 1,52 \\
\hline SOBR. & 0,44 & - & 0,00 \\
\hline AFAI & 0,87 & - & 1,13 \\
\hline
\end{tabular}


TABELA 5.29 : Análise intra-examinador da precisão do método. Valores iniciais e repetidos após dois meses (médias e desviospadrão), diferença das médias, valor de "t", de "p" e a significância estatística dos erros sistemáticos.

\begin{tabular}{c|c|c|c|c|c|c|c}
\hline \multirow{2}{*}{ Variáveis } & \multicolumn{2}{|c|}{$\begin{array}{c}\text { Valores } \\
\text { Iniciais }\end{array}$} & \multicolumn{2}{c|}{$\begin{array}{c}\text { Valores } \\
\text { Repetidos }\end{array}$} & $\begin{array}{c}\text { Diferença } \\
\text { Médias }\end{array}$ & $\mathbf{t}$ & $\mathbf{p}$ \\
\hline & $\mathbf{X}$ & $\mathbf{D . P .}$ & $\mathbf{X}$ & $\mathbf{D . P .}$ & & & \\
\hline NC-CN1 & 26,56 & 1,09 & 26,74 & 1,09 & $-0,18$ & $-1,00$ & 0,373 \\
\hline NC-CN2 & 28,32 & 1,26 & 28,68 & 1,10 & $-0,36$ & $-1,63$ & 0,177 \\
\hline NC-CN3 & 28,32 & 1,26 & 28,48 & 1,10 & $-0,16$ & $-0,45$ & 0,673 \\
\hline JL-JR1 & 60,60 & 0,50 & 60,90 & 1,09 & $-0,30$ & $-0,55$ & 0,607 \\
\hline JL-JR2 & 63,02 & 0,67 & 63,40 & 0,54 & $-0,38$ & $-0,76$ & 0,484 \\
\hline JL-JR3 & 63,90 & 1,24 & 63,80 & 0,83 & 0,10 & 0,40 & 0,704 \\
\hline RSR1 & 46,94 & 3,25 & 46,54 & 3,22 & 0,40 & 0,88 & 0,427 \\
\hline RSR2 & 52,14 & 3,97 & 51,60 & 3,36 & 0,54 & 0,72 & 0,508 \\
\hline RSR3 & 54,44 & 3,35 & 55,10 & 2,88 & $-0,66$ & $-1,27$ & 0,272 \\
\hline CSC1 & 52,20 & 2,52 & 51,82 & 2,24 & 0,37 & 1,49 & 0,209 \\
\hline CSC2 & 59,04 & 3,08 & 59,14 & 2,99 & $-0,10$ & $-1,00$ & 0,373 \\
\hline CSC3 & 60,72 & 2,32 & 60,54 & 2,42 & 0,18 & 0,49 & 0,646 \\
\hline CIC1 & 56,66 & 2,61 & 56,44 & 2,40 & 0,22 & 0,61 & 0,572 \\
\hline CIC2 & 56,64 & 2,21 & 56,64 & 2,21 & 0,00 & 0,00 & 1,000 \\
\hline CIC3 & 56,84 & 2,61 & 56,66 & 1,77 & 0,18 & 0,38 & 0,722 \\
\hline A6-JL1 & 8,28 & 1,78 & 8,68 & 1,96 & $-0,40$ & $-1,63$ & 0,177 \\
\hline A6-JL2 & 5,78 & 1,18 & 5,78 & 1,37 & 0,00 & 0,00 & 1,000 \\
\hline A6-JL3 & 4,80 & 0,70 & 4,80 & 0,70 & 0,00 & 0,00 & 1,000 \\
\hline 6A-JR1 & 8,40 & 0,83 & 8,90 & 0,44 & $-0,50$ & $-2,23$ & 0,089 \\
\hline 6A-JR2 & 5,68 & 0,86 & 5,94 & 1,04 & $-0,26$ & $-1,46$ & 0,217 \\
\hline 6A-JR3 & 4,70 & 0,741 & 4,80 & 1,00 & $-0,10$ & $-0,25$ & 0,814 \\
\hline 6R.Z1 & 81,20 & 4,54 & 82,2 & 2,94 & $-1,00$ & $-0,51$ & 0,630 \\
\hline 6R.Z2 & 75,20 & 6,61 & 74,00 & 3,93 & 1,20 & 0,63 & 0,558 \\
\hline 6R.Z3 & 73,60 & 4,15 & 78,20 & 3,11 & 3,78 & $-2,72$ & 0,052 \\
\hline 6L.Z1 & 82,80 & 3,11 & 81,80 & 3,89 & 1,00 & 1,19 & 0,298 \\
\hline 6L.Z2 & 74,80 & 2,16 & 76,40 & 2,96 & $-1,60$ & $-0,94$ & 0,397 \\
\hline 6L.Z3 & 80,60 & 2,30 & 80,60 & 2,30 & 0,00 & 0,00 & 1,000 \\
\hline AI-IA1 & 6,16 & 0,49 & 6,72 & 0,67 & $-0,56$ & $-2,44$ & 0,071 \\
\hline & & & & & & & \\
\hline
\end{tabular}




\begin{tabular}{c|c|c|c|c|c|c|c}
\multirow{2}{*}{ Variáveis } & \multicolumn{2}{|c|}{$\begin{array}{c}\text { Valores } \\
\text { Iniciais }\end{array}$} & \multicolumn{2}{c|}{$\begin{array}{c}\text { Valores } \\
\text { Repetidos }\end{array}$} & $\begin{array}{c}\text { Diferença } \\
\text { Médias }\end{array}$ & $\mathbf{t}$ & $\mathbf{p}$ \\
& $\mathbf{X}$ & $\mathbf{D . P .}$ & $\mathbf{X}$ & $\mathbf{D . P .}$ & & & \\
\hline AI-IA2 & 10,92 & 1,52 & 10,72 & 1,20 & 0,20 & 0,43 & 0,688 \\
\hline AI-IA3 & 9,48 & 0,80 & 9,68 & 0,67 & $-0,20$ & $-1,00$ & 0,373 \\
\hline IM-MI1 & 0,54 & 0,49 & 0,36 & 0,49 & 0,18 & 1,00 & 0,373 \\
\hline IM-MI2 & 3,44 & 1,09 & 3,06 & 1,43 & 0,38 & 1,62 & 0,178 \\
\hline IM-MI3 & 0,18 & 0,40 & 0,00 & 0,00 & 0,18 & 1,00 & 0,373 \\
\hline A1R.Z1 & 86,90 & 2,60 & 88,20 & 2,86 & $-1,30$ & $-1,85$ & 0,136 \\
\hline A1R.Z2 & 90,20 & 3,17 & 91,00 & 3,80 & $-0,80$ & $-0,72$ & 0,508 \\
\hline A1R.Z3 & 92,90 & 2,88 & 92,80 & 4,38 & 0,10 & 0,12 & 0,907 \\
\hline A1L.Z1 & 86,30 & 2,68 & 88,00 & 4,06 & $-1,70$ & $-1,27$ & 0,272 \\
\hline A1L.Z2 & 90,20 & 5,21 & 89,00 & 5,70 & 1,20 & 1,50 & 0,208 \\
\hline A1L.Z3 & 92,00 & 3,93 & 92,90 & 5,85 & $-0,90$ & $-0,91$ & 0,410 \\
\hline SOBR.1 & 1,32 & 1,59 & 1,72 & 1,70 & $-0,40$ & $-1,63$ & 0,177 \\
\hline SOBR.3 & 1,32 & 1,10 & 1,32 & 1,10 & 0,00 & 0,00 & 1,000 \\
\hline AFAI 1 & 65,58 & 6,51 & 63,82 & 6,18 & 1,76 & 4,94 & $0,007 *$ \\
\hline AFAI 3 & 65,96 & 6,19 & 64,82 & 6,18 & 1,14 & 2,02 & 0,112 \\
\hline
\end{tabular}

$X$ : média

D.P.- desvio padrão

* - estatisticamente significante $(\mathrm{p}<0,05)$ 
TABELA 5.30 : Análise interexaminadores da precisão do método. Valores (médias e desvios-padrão) obtidos por MAZZIEIRO ${ }^{65}$ e pelo autor, diferenças das médias, valores de "t", de "p" e as significâncias estatísticas.

\begin{tabular}{c|c|c|c|c|c|c|c}
\hline \multirow{2}{*}{ Variáveis } & \multicolumn{2}{|c|}{$\begin{array}{c}\text { Valores } \\
\text { MAZZIEIRO }\end{array}$} & \multicolumn{2}{c|}{$\begin{array}{c}\text { Valores } \\
\text { Autor }\end{array}$} & $\begin{array}{c}\text { Diferenças } \\
\text { Médias }\end{array}$ & $\mathbf{t}$ & p \\
\hline & $\mathbf{X}$ & $\mathbf{D . P .}$ & $\mathbf{X}$ & $\mathbf{D . P .}$ & & & \\
\hline NC-CN & 29,75 & 3,04 & 29,66 & 2,93 & 0,08 & 0,43 & 0,674 \\
\hline JL-JR & 62,16 & 2,85 & 62,33 & 3,08 & $-0,16$ & $-1,00$ & 0,338 \\
\hline RSR & 49,33 & 5,05 & 48,91 & 4,87 & 0,41 & 2,15 & 0,053 \\
\hline CSC & 57,20 & 5,65 & 57,45 & 5,40 & $-0,25$ & $-1,39$ & 0,191 \\
\hline CIC & 58,33 & 4,22 & 58,58 & 4,13 & $-0,25$ & $-2,17$ & 0,052 \\
\hline A6-JL & 7,41 & 2,53 & 7,00 & 2,48 & 0,41 & 1,82 & 0,096 \\
\hline 6A-JR & 6,58 & 2,54 & 6,41 & 2,42 & 0,16 & 1,30 & 0,219 \\
\hline 6R.Z & 78,87 & 6,22 & 77,16 & 7,12 & 1,70 & 3,09 & $0,010 *$ \\
\hline 6L.Z & 68,87 & 3,41 & 69,83 & 4,10 & $-0,95$ & $-2,00$ & 0,070 \\
\hline AI-IA & 7,58 & 2,50 & 7,70 & 2,49 & $-0,12$ & $-1,14$ & 0,274 \\
\hline IM-MI & 0,79 & 1,49 & 0,91 & 1,67 & $-0,12$ & $-1,39$ & 0,191 \\
\hline A1R.Z & 87,04 & 5,47 & 87,50 & 5,40 & $-0,45$ & $-1,28$ & 0,224 \\
\hline A1L.Z & 85,25 & 3,25 & 85,08 & 2,71 & 0,16 & 0,32 & 0,754 \\
\hline SOBR. & 1,08 & 2,64 & 1,33 & 2,80 & $-0,25$ & $-1,91$ & 0,081 \\
\hline
\end{tabular}

$X$ : média

D.P.- desvio padrão

* - estatisticamente significante $(\mathrm{p}<0,05)$ 
TABELA 5.31 : Médias (X), desvios-padrão (D.P.) dos valores iniciais (fase pré-expansão), valor de “p” e a significância estatística da análise de variância aplicada na comparação dos três grupos.

\begin{tabular}{c|c|c|c|c|c|c|c}
\hline \multirow{2}{*}{ Grupos } & \multicolumn{2}{|c|}{$\begin{array}{c}\text { HAAS } \\
\text { N= 20 }\end{array}$} & \multicolumn{2}{c|}{$\begin{array}{c}\text { HYRAX } \\
\mathbf{N}=\mathbf{2 1}\end{array}$} & \multicolumn{2}{c|}{$\begin{array}{c}\text { COLADO } \\
\mathbf{N}=\mathbf{2 2}\end{array}$} & P \\
\hline Variáveis & X & D.P. & X & D.P. & X & D.P. & \\
\hline NC-CN & 28,92 & 2,29 & 29,38 & 3,02 & 27,08 & 2,20 & $0,010 *$ \\
\hline JL-JR & 61,25 & 2,73 & 61,85 & 3,02 & 60,50 & 2,96 & $0,319 \mathrm{~ns}$ \\
\hline RSR & 48,37 & 3,34 & 48,30 & 3,70 & 47,20 & 3,77 & $0,493 \mathrm{~ns}$ \\
\hline CSC & 55,67 & 3,02 & 55,57 & 2,83 & 52,44 & 3,35 & $0,001 *$ \\
\hline CIC & 57,12 & 3,52 & 57,92 & 3,19 & 56,22 & 2,71 & $0,215 \mathrm{~ns}$ \\
\hline A6-JL & 7,65 & 1,63 & 8,09 & 1,86 & 8,99 & 1,89 & $0,055 \mathrm{~ns}$ \\
\hline 6A-JR & 7,35 & 1,53 & 7,40 & 1,44 & 8,81 & 2,28 & $0,014 *$ \\
\hline 6R.Z & 79,50 & 4,31 & 78,66 & 4,62 & 79,75 & 3,77 & $0,686 \mathrm{~ns}$ \\
\hline 6L.Z & 70,20 & 2,93 & 69,38 & 3,77 & 84,09 & 4,08 & $0,000 *$ \\
\hline AI-IA & 7,25 & 1,05 & 6,57 & 1,46 & 6,57 & 1,40 & $0,180 \mathrm{~ns}$ \\
\hline IM-MI & 0,00 & 0,00 & 0,00 & 0,00 & 0,43 & 0,69 & $0,000 *$ \\
\hline A1R.Z & 88,77 & 4,65 & 87,04 & 3,65 & 88,31 & 3,65 & $0,360 \mathrm{~ns}$ \\
\hline A1L.Z & 86,4 & 4,46 & 86,61 & 5,31 & 86,13 & 3,55 & $0,939 \mathrm{~ns}$ \\
\hline SOBR. & 1,22 & 1,39 & 0,90 & 2,21 & 1,35 & 1,96 & $0,729 \mathrm{~ns}$ \\
\hline AFAI & 65,55 & 5,88 & 64,09 & 4,74 & 64,52 & 6,90 & $0,724 \mathrm{~ns}$ \\
\hline
\end{tabular}

* - estatisticamente significante $(\mathrm{p}<0,05)$

ns - estatisticamente não significante 
Os gráficos 5.1 a 5.15 demostram os valores médios das variáveis analisadas para os três grupos, nas fases pré-expansão, pós-expansão e póscontenção.

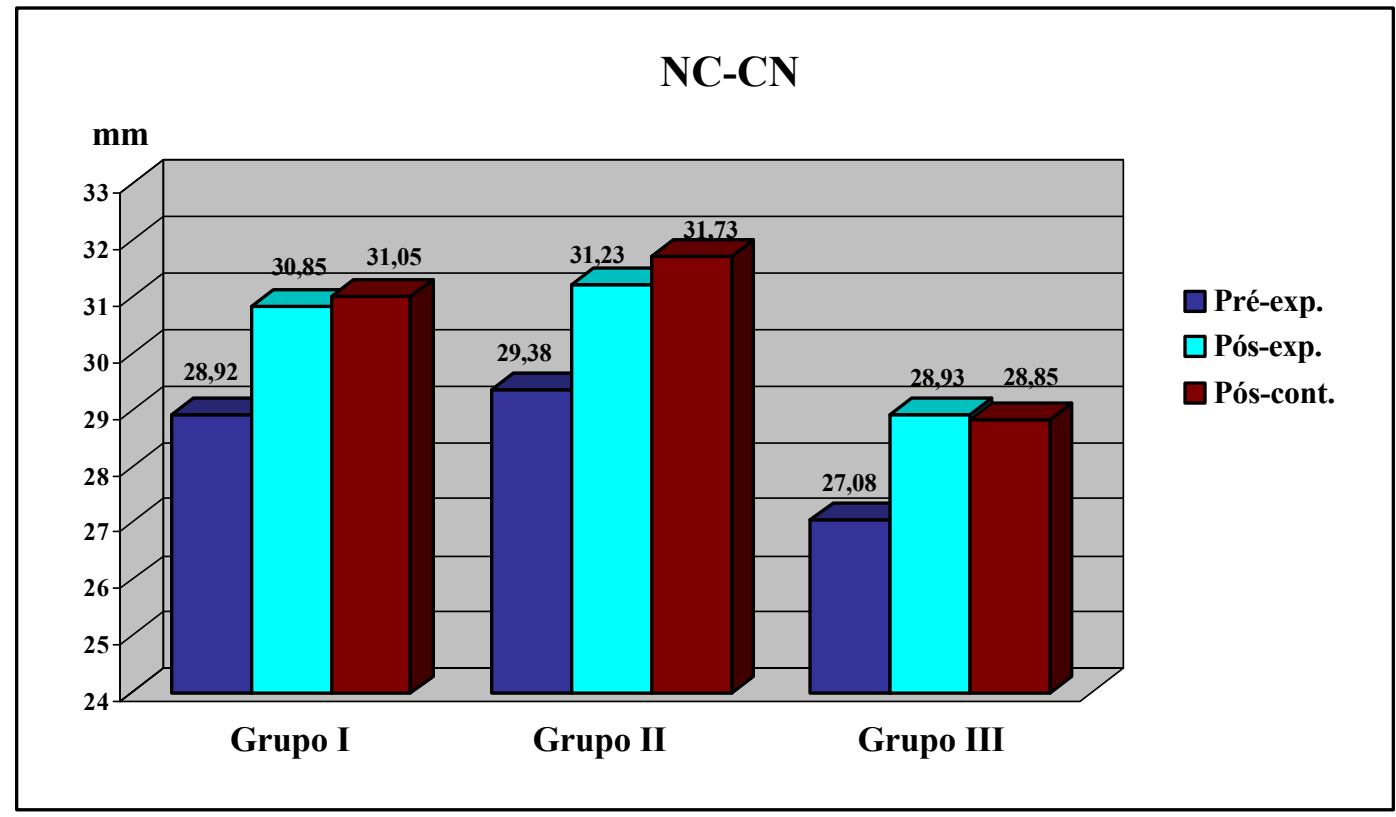

GRÁFICO 5.1 - Valores médios observados para a variável NC-CN

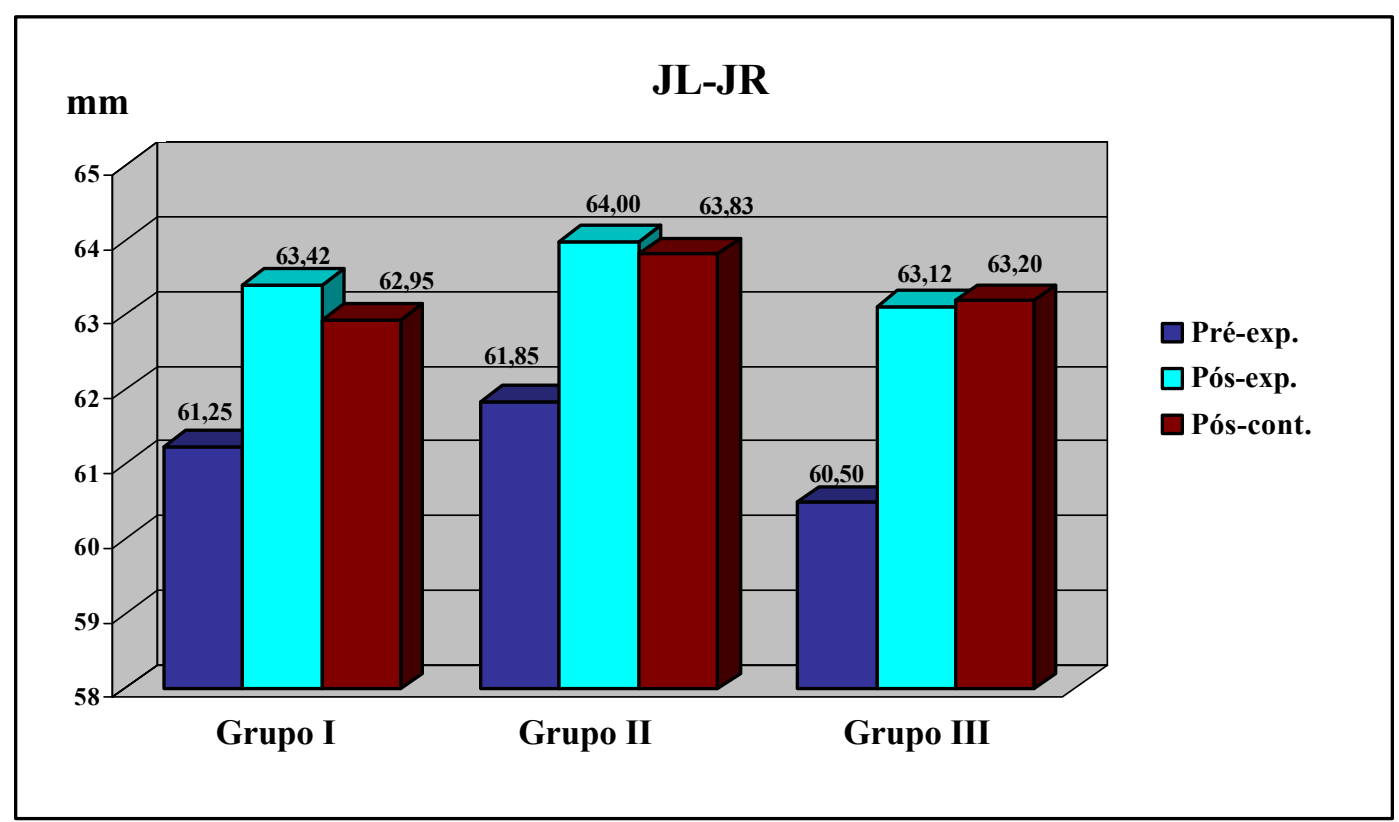

GRÁFICO 5.2 - Valores médios observados para a variável JL-JR 


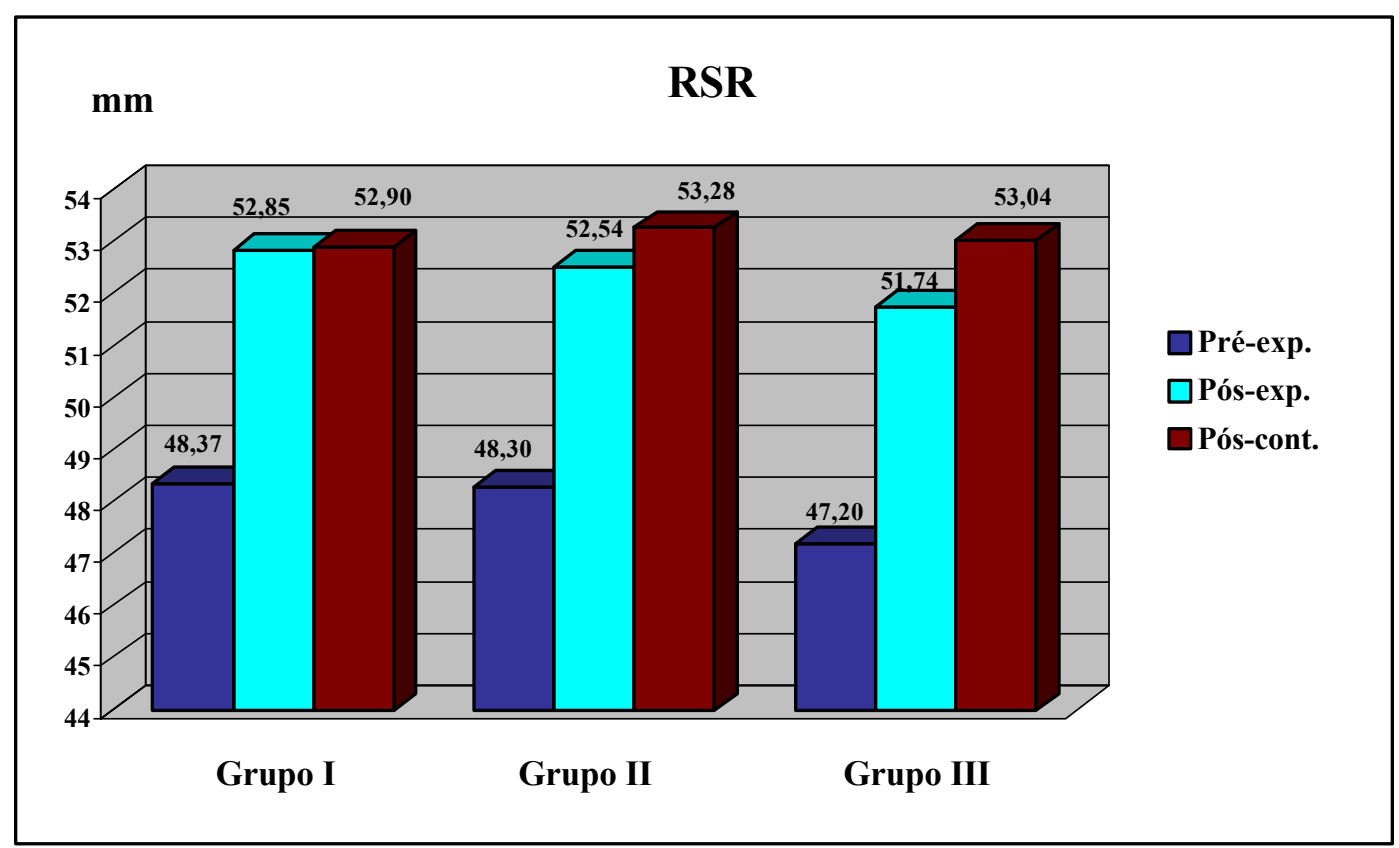

GRÁFICO 5.3 - Valores médios observados para a variável RSR

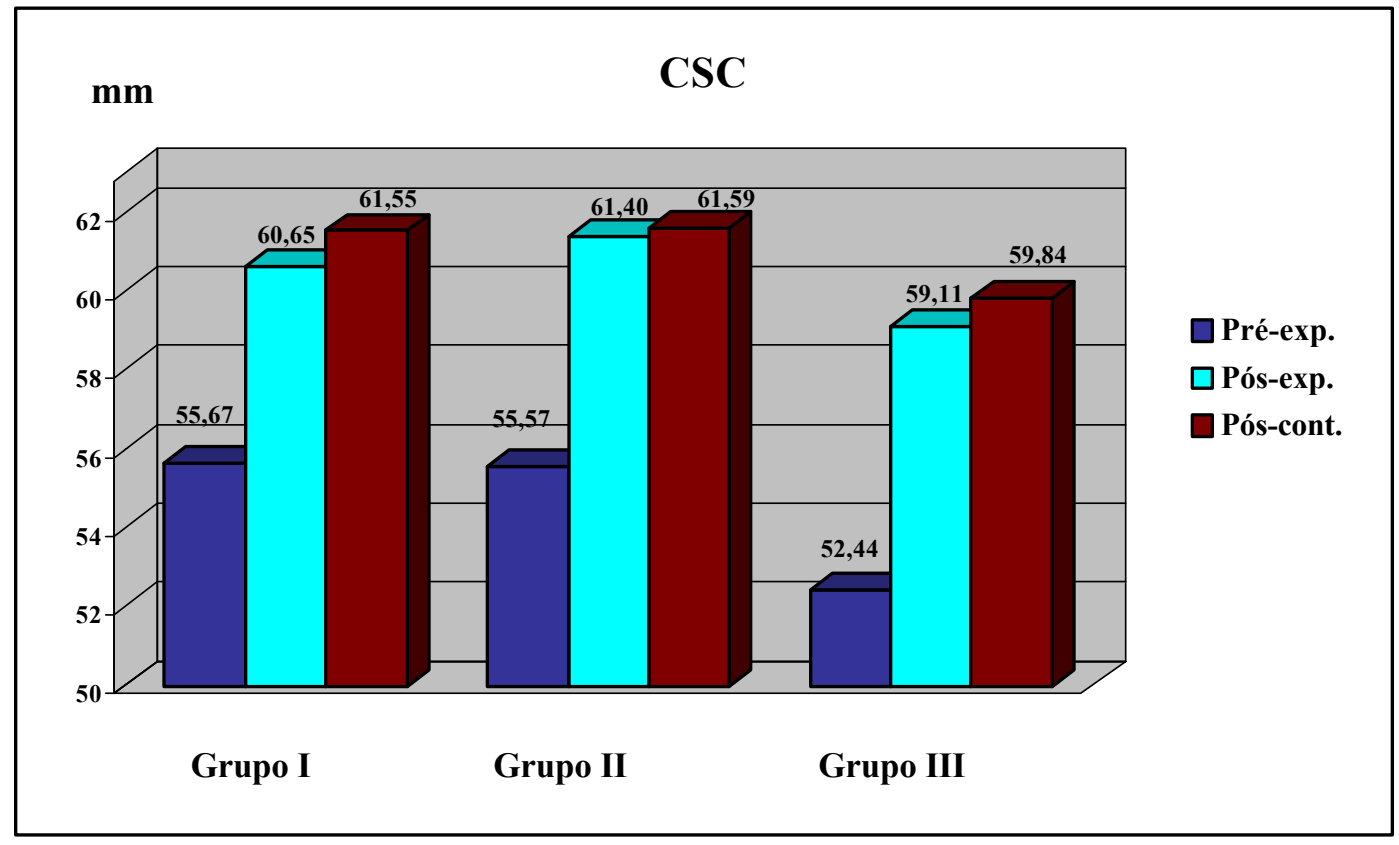

GRÁFICO 5.4 - Valores médios observados para a variável CSC 


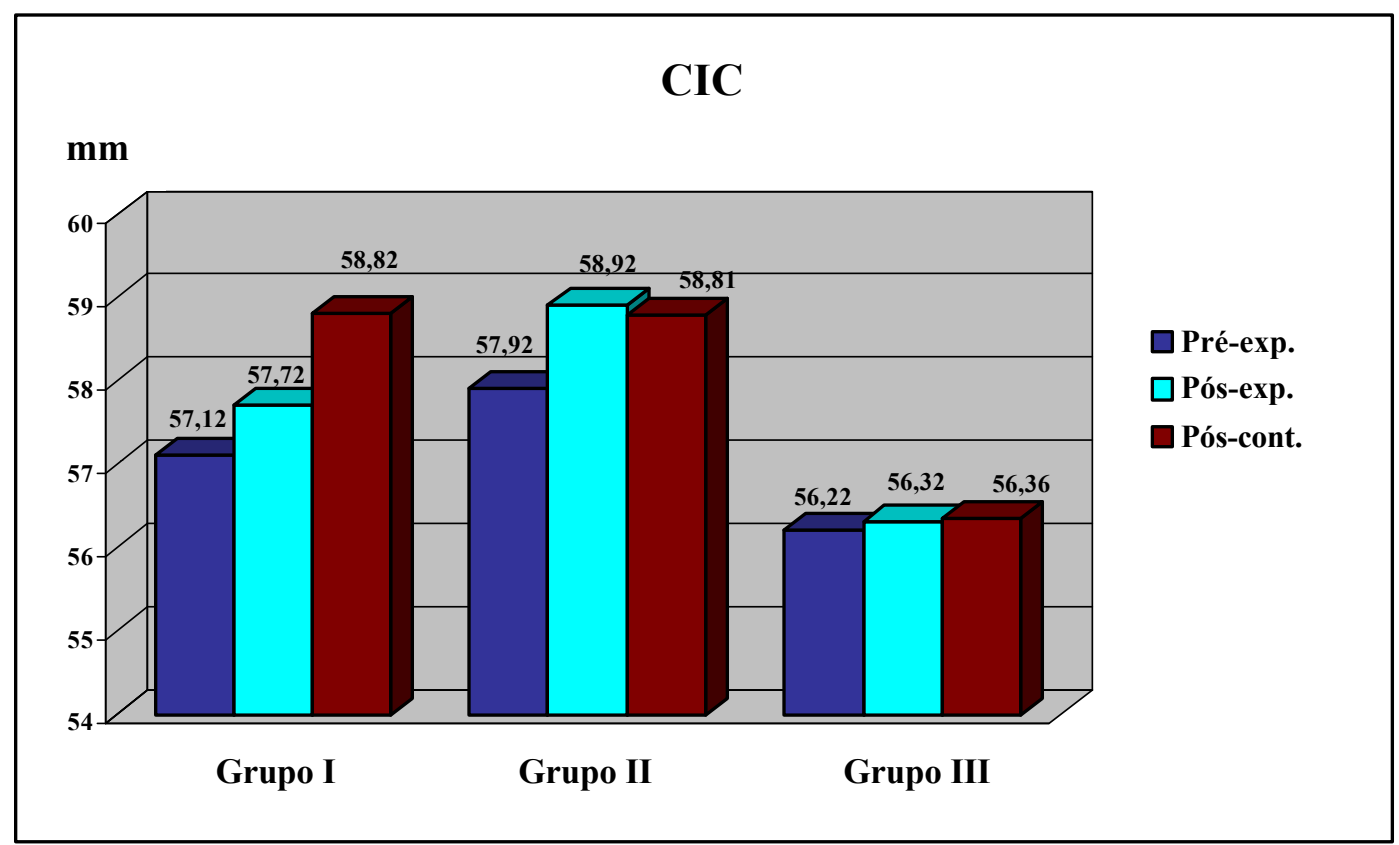

GRÁFICO 5.5 - Valores médios observados para a variável CIC

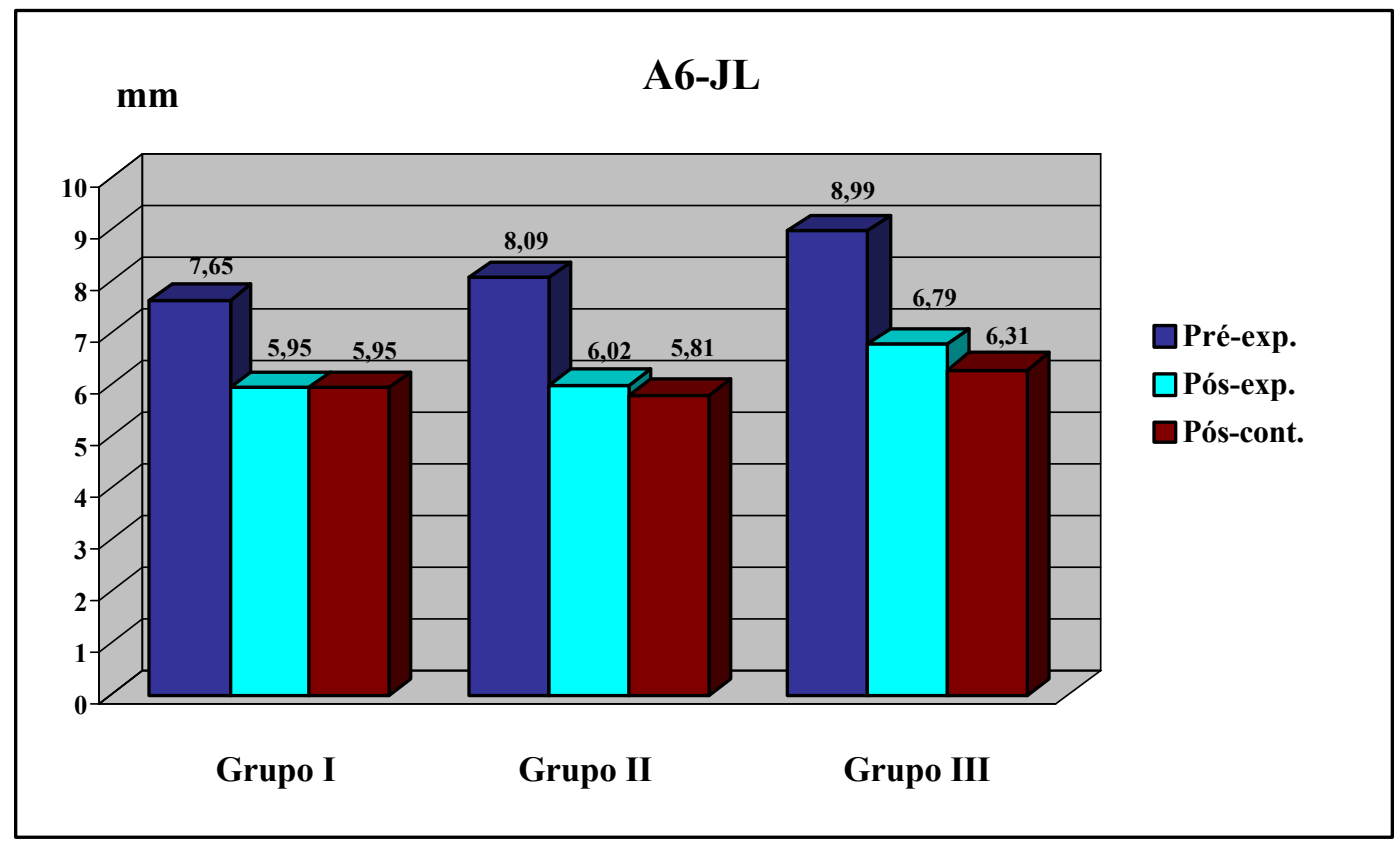

GRÁFICO 5.6 - Valores médios observados para a variável A6-JL 


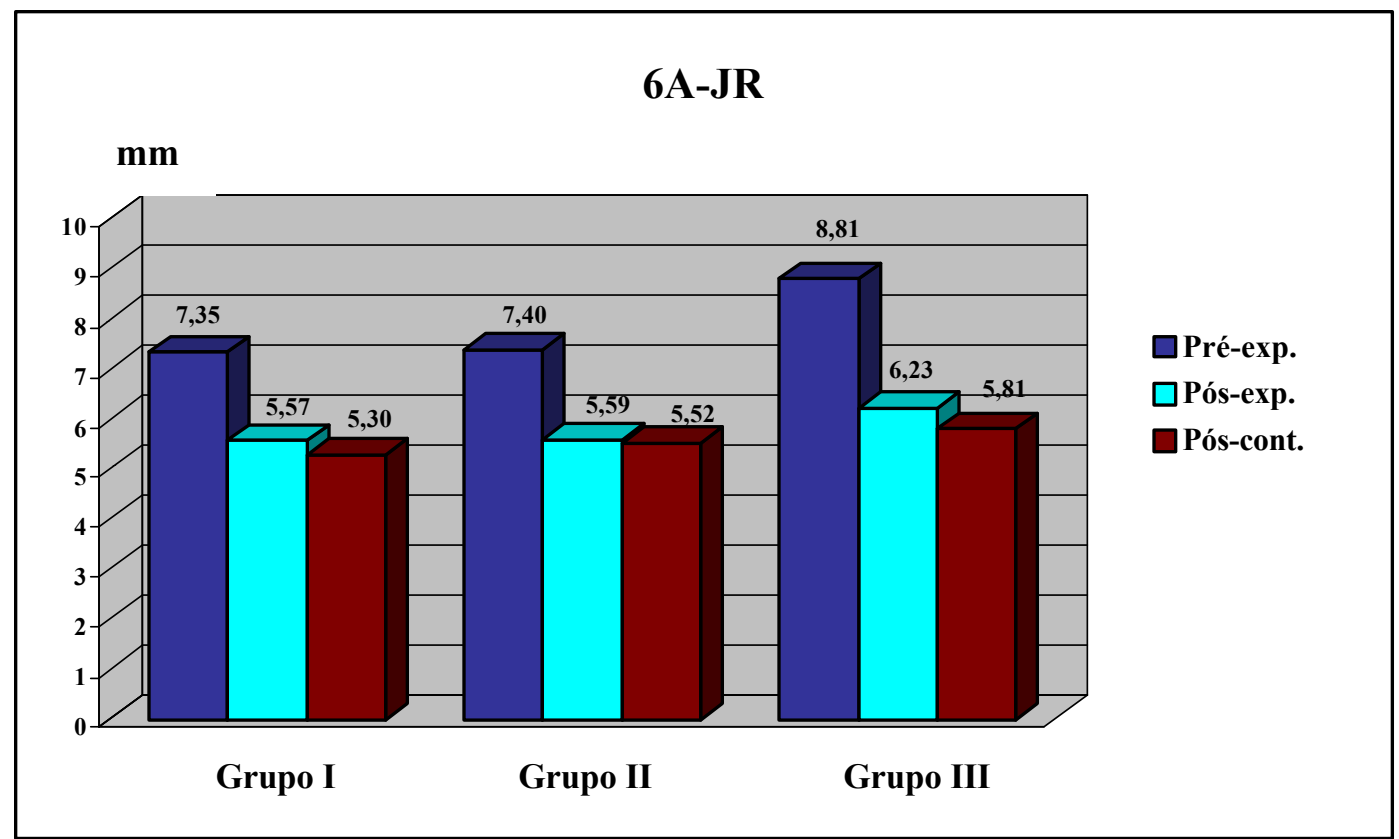

GRÁFICO 5.7 - Valores médios observados para a variável 6A-JR

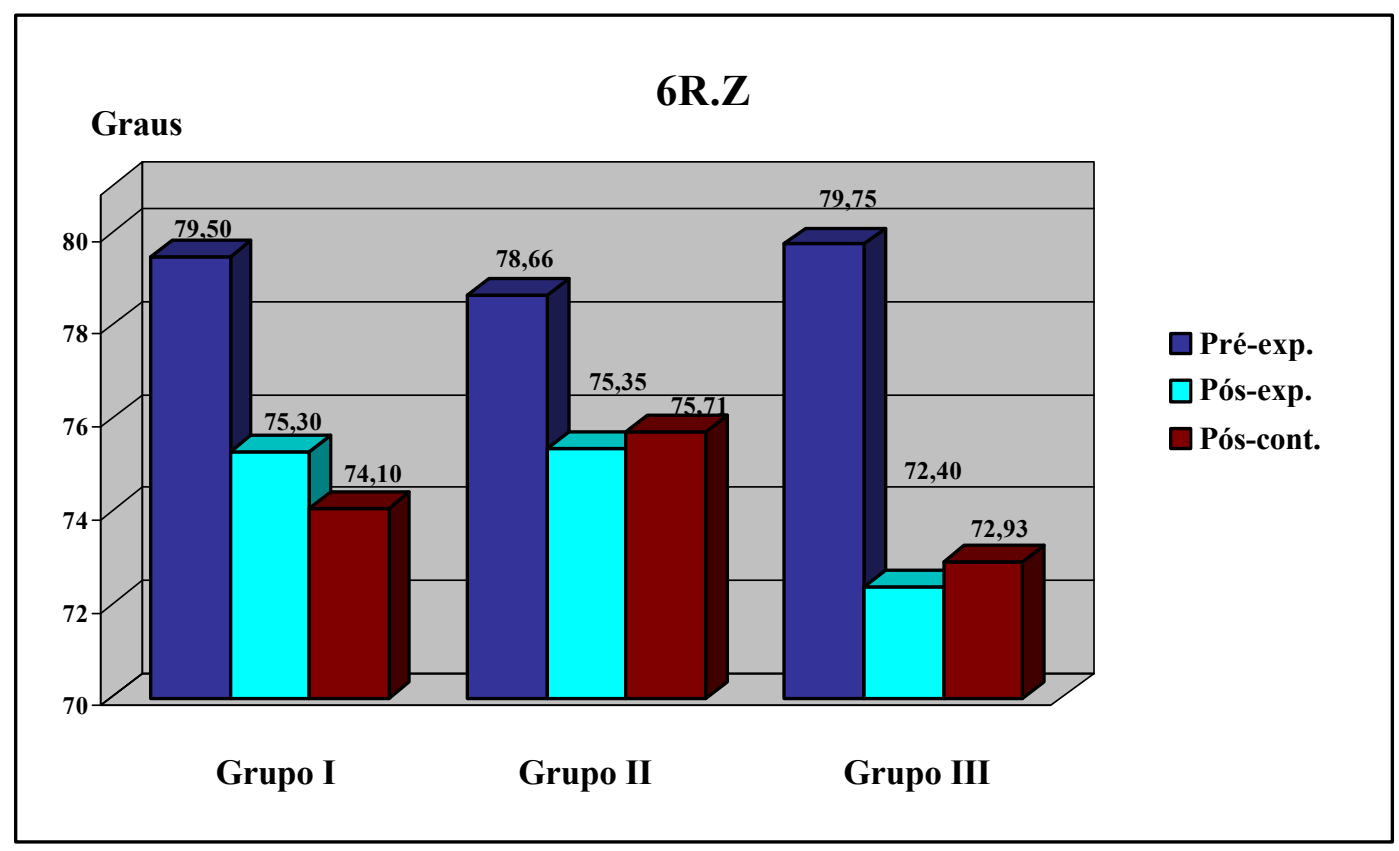

GRÁFICO 5.8 - Valores médios observados para a variável 6R.Z 


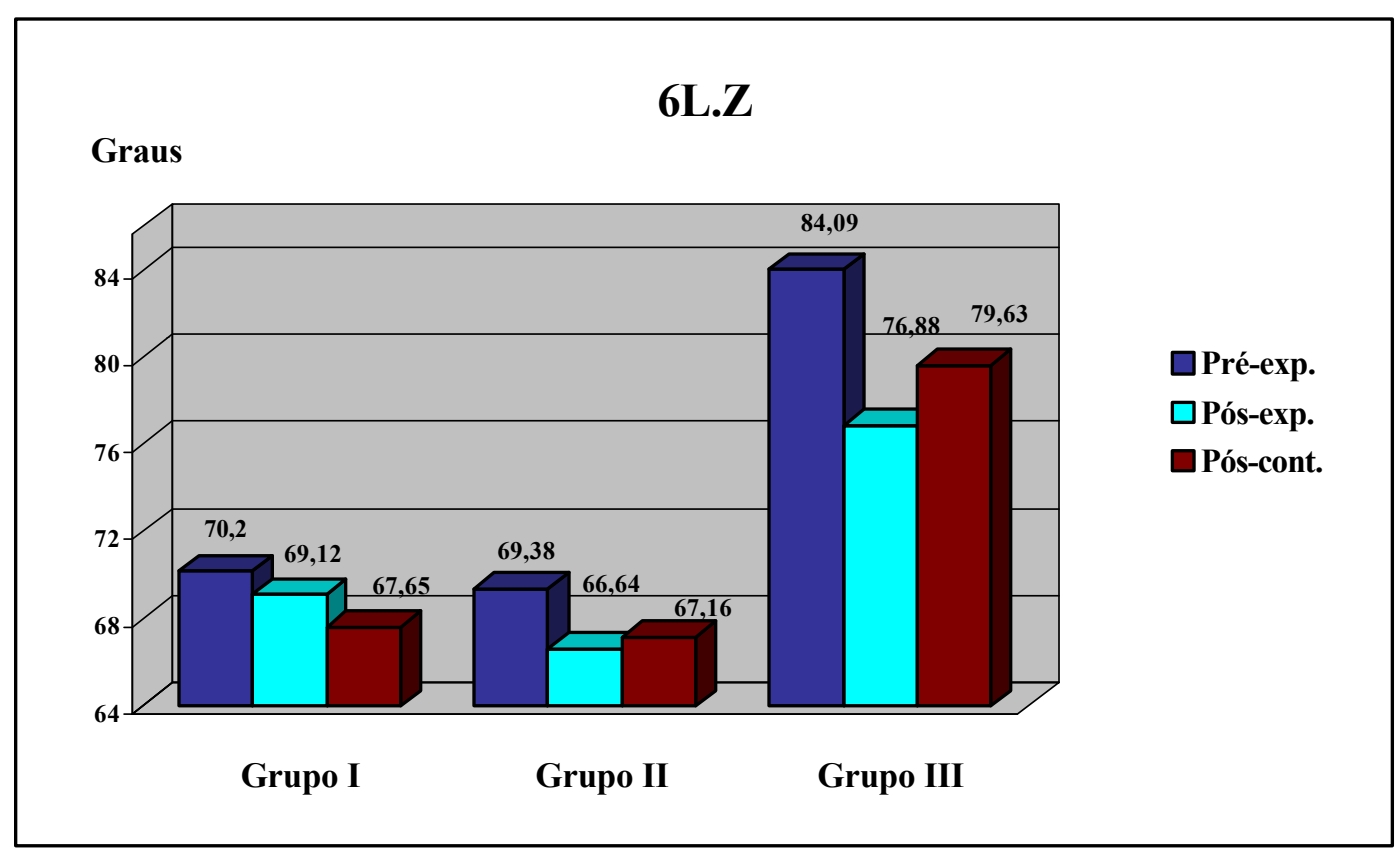

GRÁFICO 5.9 - Valores médios observados para a variável 6L.Z

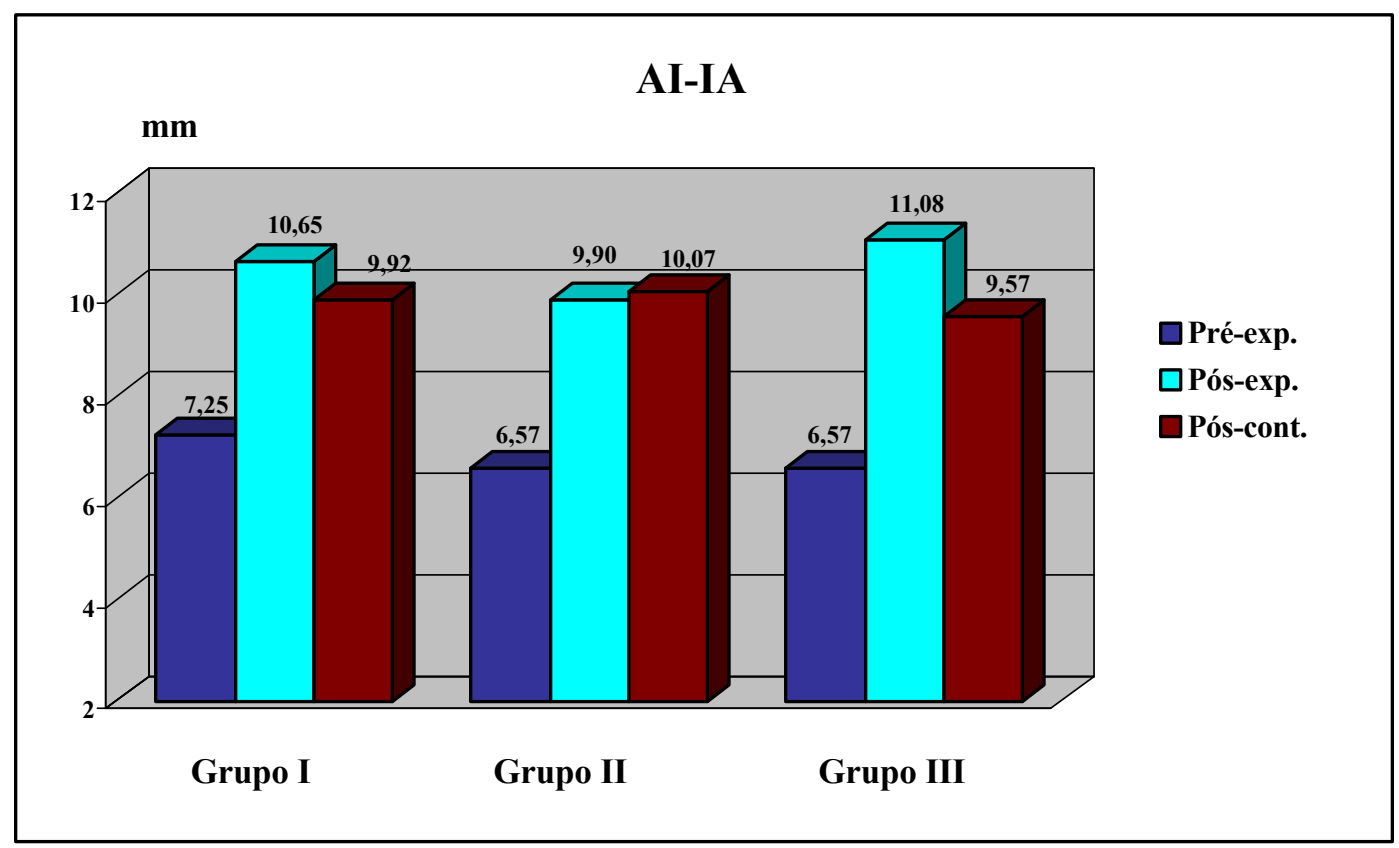

GRÁFICO 5.10 - Valores médios observados para a variável AI-IA 


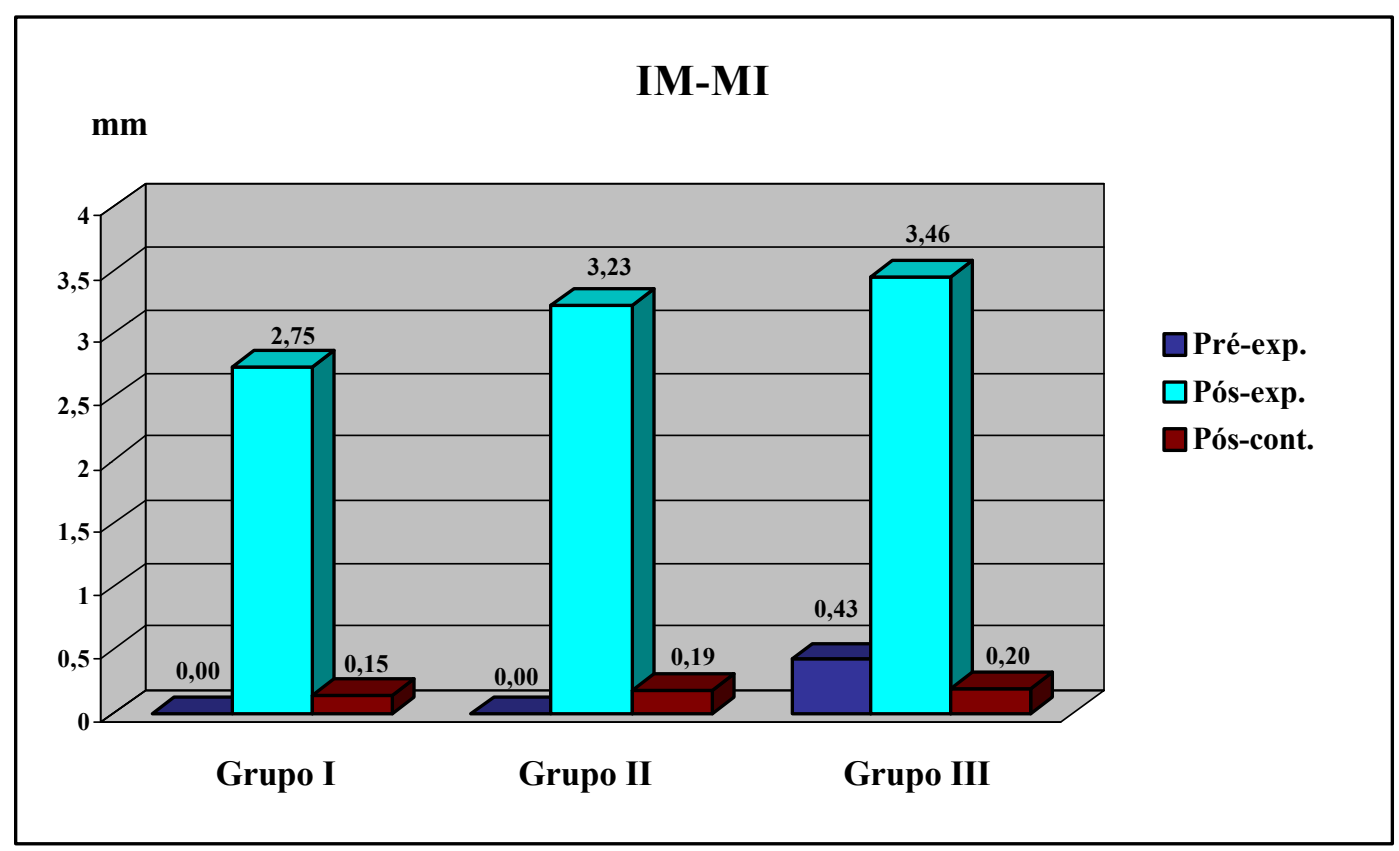

GRÁFICO 5.11 - Valores médios observados para a variável IM-MI

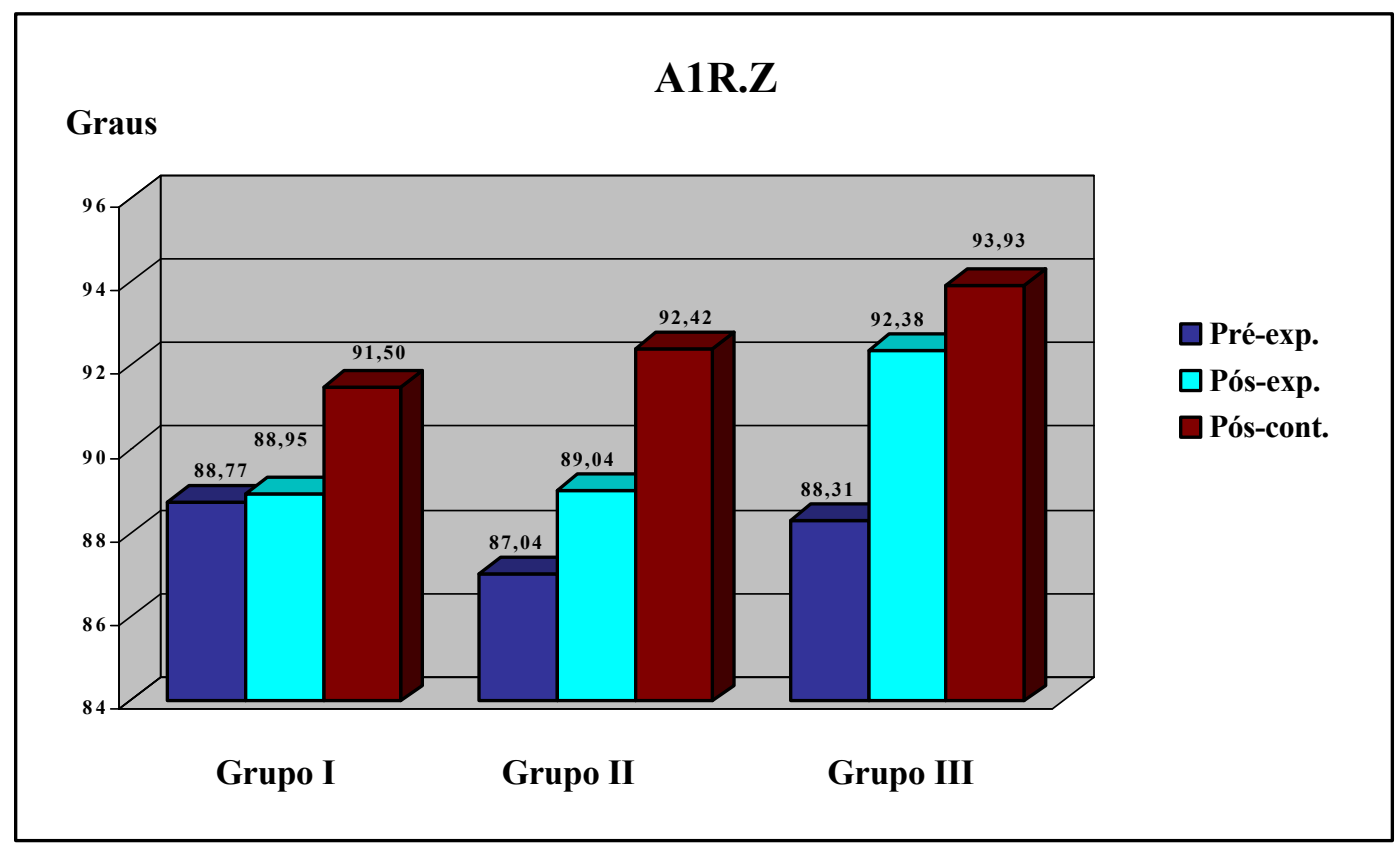

GRÁFICO 5.12 - Valores médios observados para a variável A1R.Z 


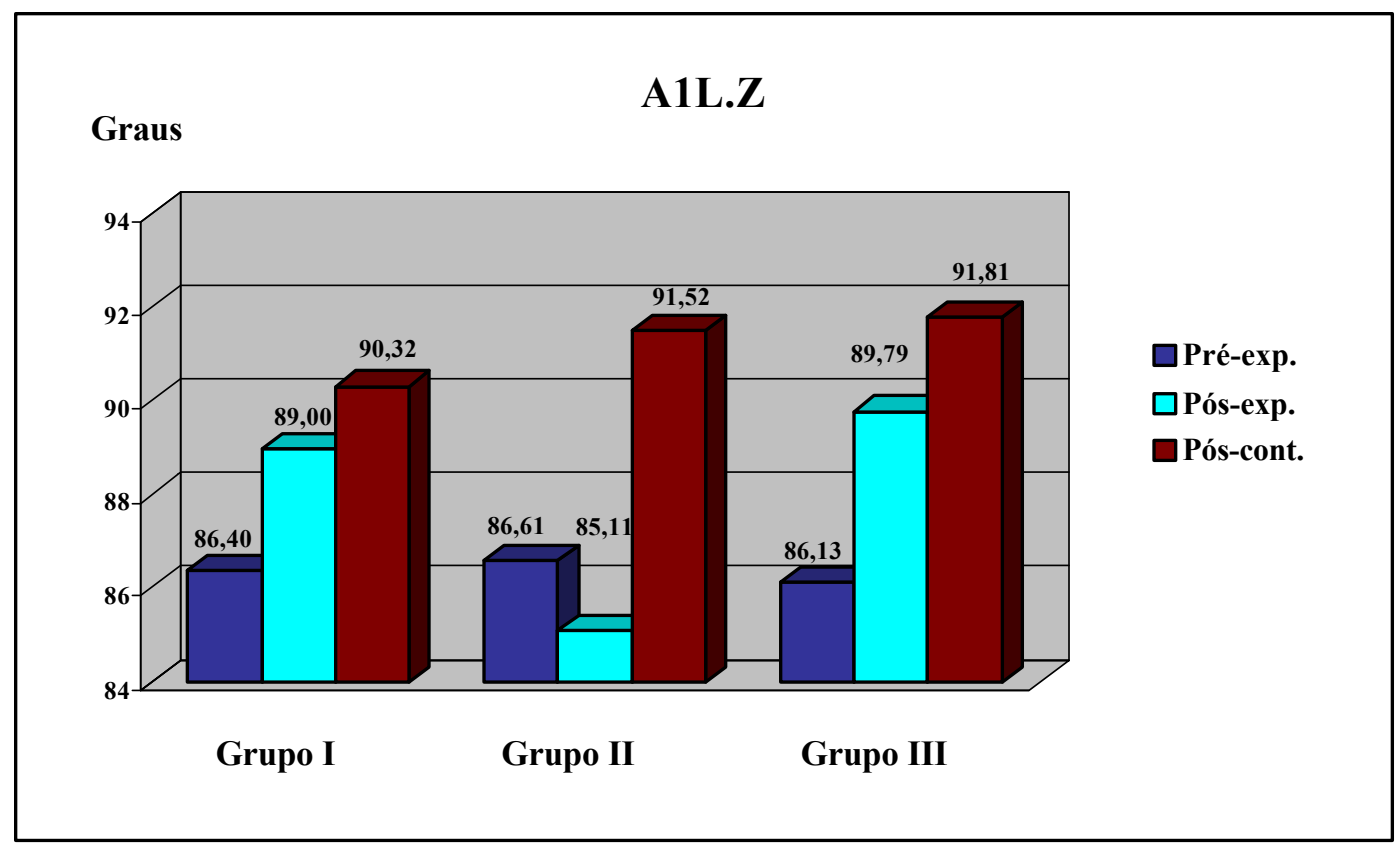

GRÁFICO 5.13 - Valores médios observados para a variável A1L.Z

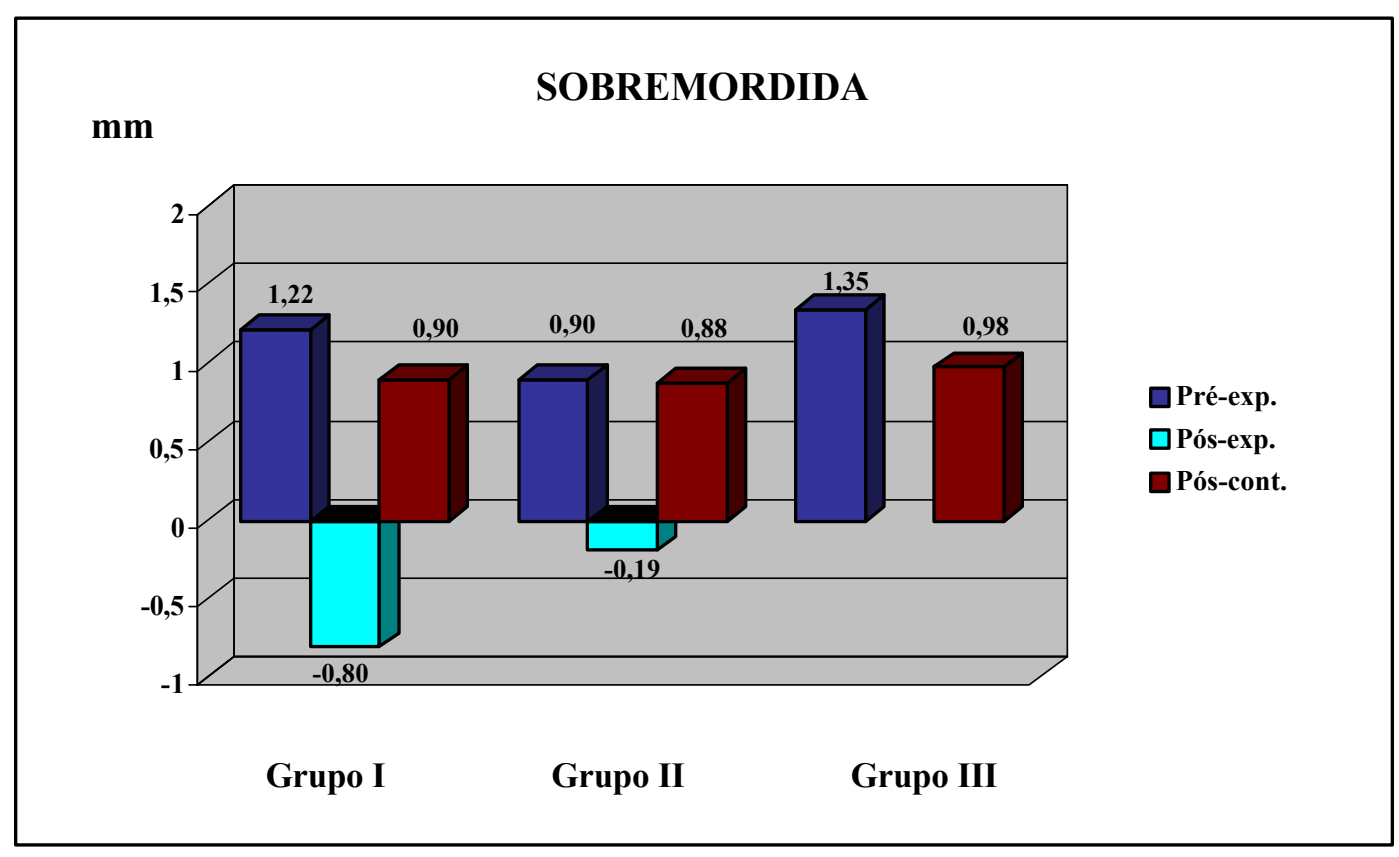

GRÁFICO 5.14 - Valores médios observados para a variável SOBREMORDIDA 


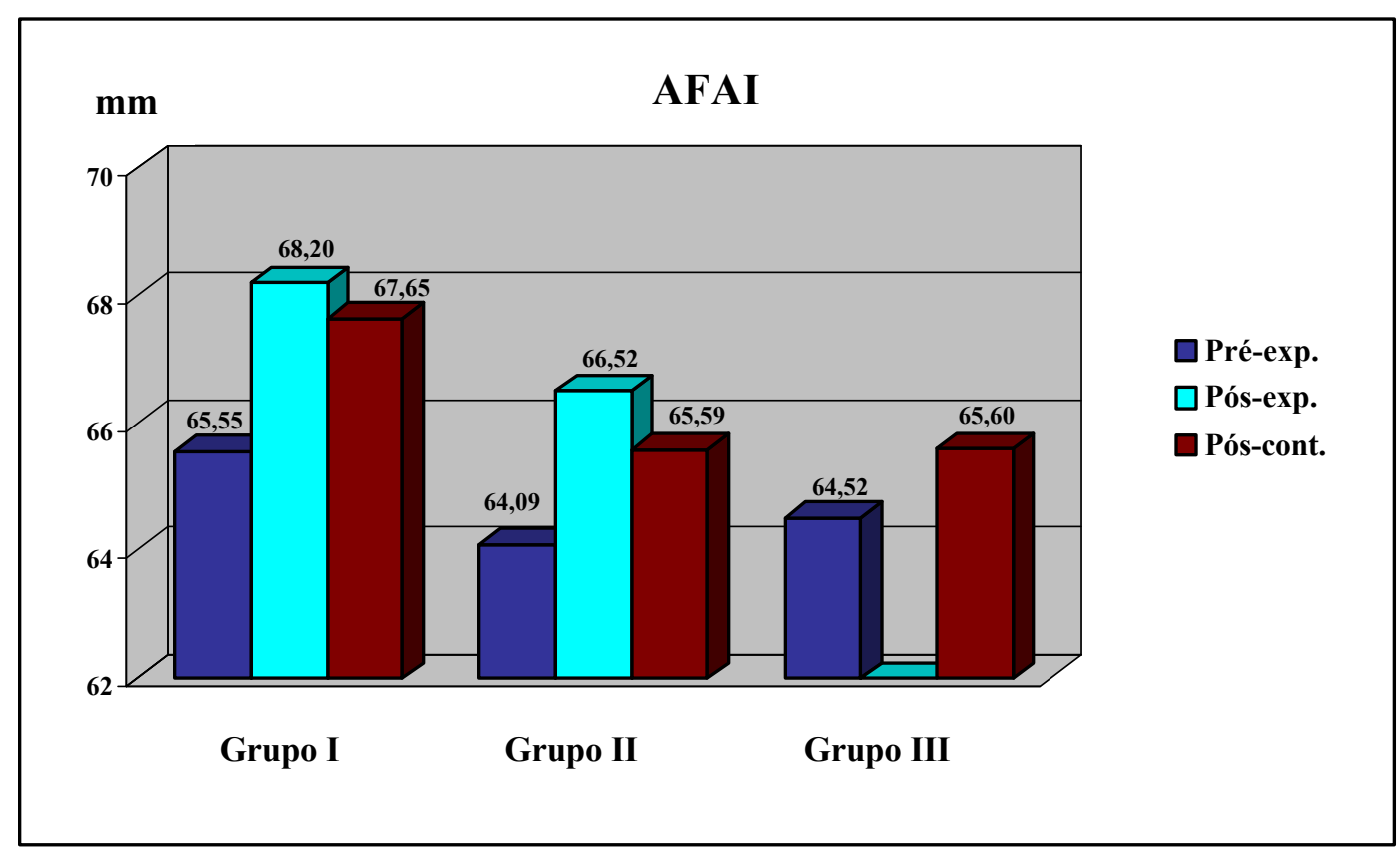

GRÁFICO 5.15 - Valores médios observados para a variável AFAI 
Para facilitar a visualização da magnitude das alterações ocorridas, os Gráficos 5.16 a 5.27 demonstram as variações percentuais dos três grupos estudados, nos períodos : - pré-expansão até pós-expansão (fase 2-1); - pósexpansão até pós-contenção (fase 3-2); - pré-expansão até pós-contenção (fase 3-1).

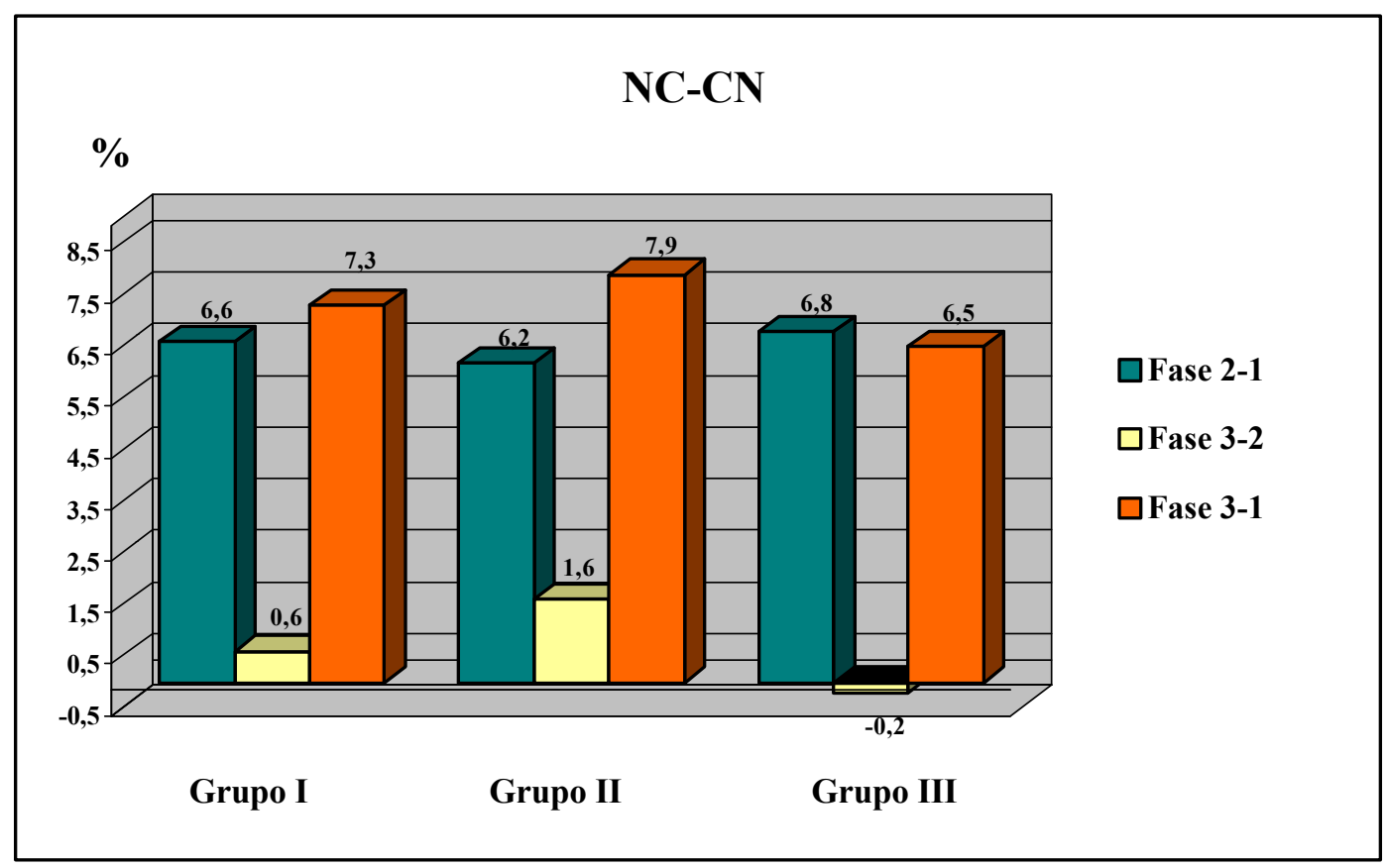

GRÁFICO 5.16 - Variações percentuais observadas para a medida NC$\mathrm{CN}$, nos três grupos estudados. 


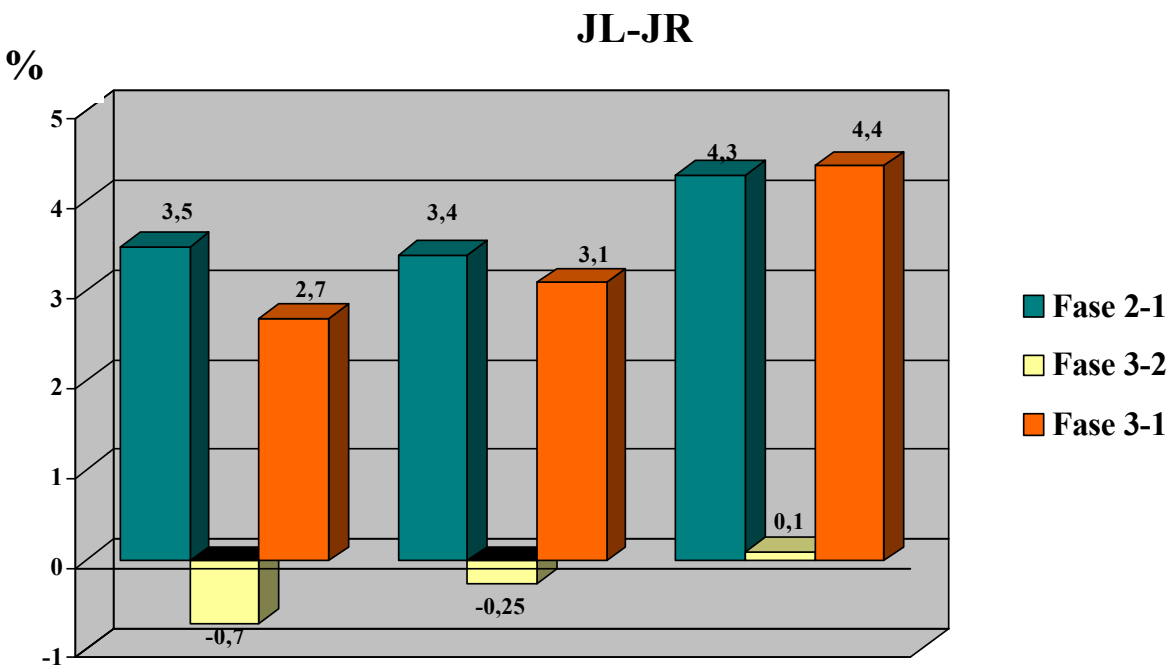

Grupo I Grupo II Grupo III

GRÁFICO 5.17 - Variações percentuais observadas para a medida JL-JR, nos três grupos estudados.
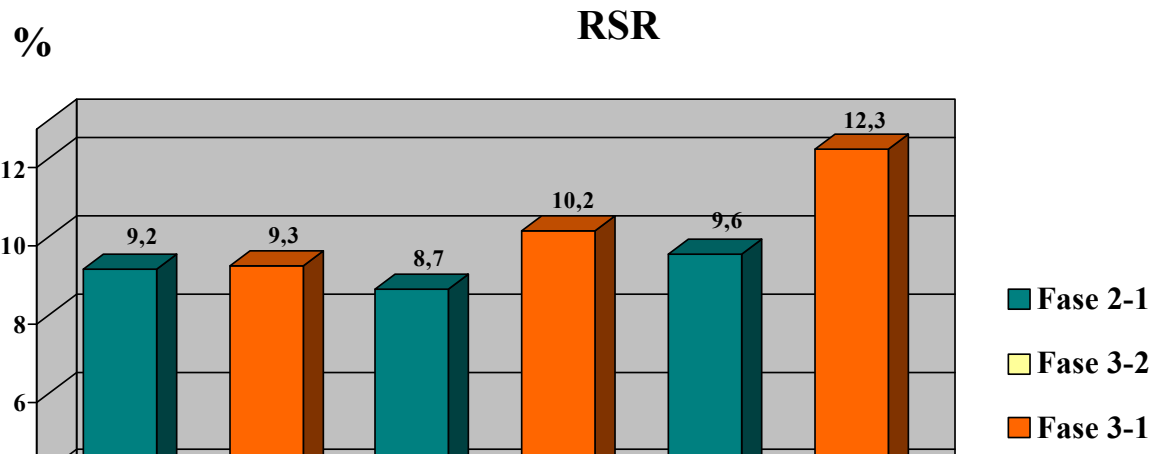

GRÁFICO 5.18 - Variações percentuais observadas para a medida RSR, nos três grupos estudados. 


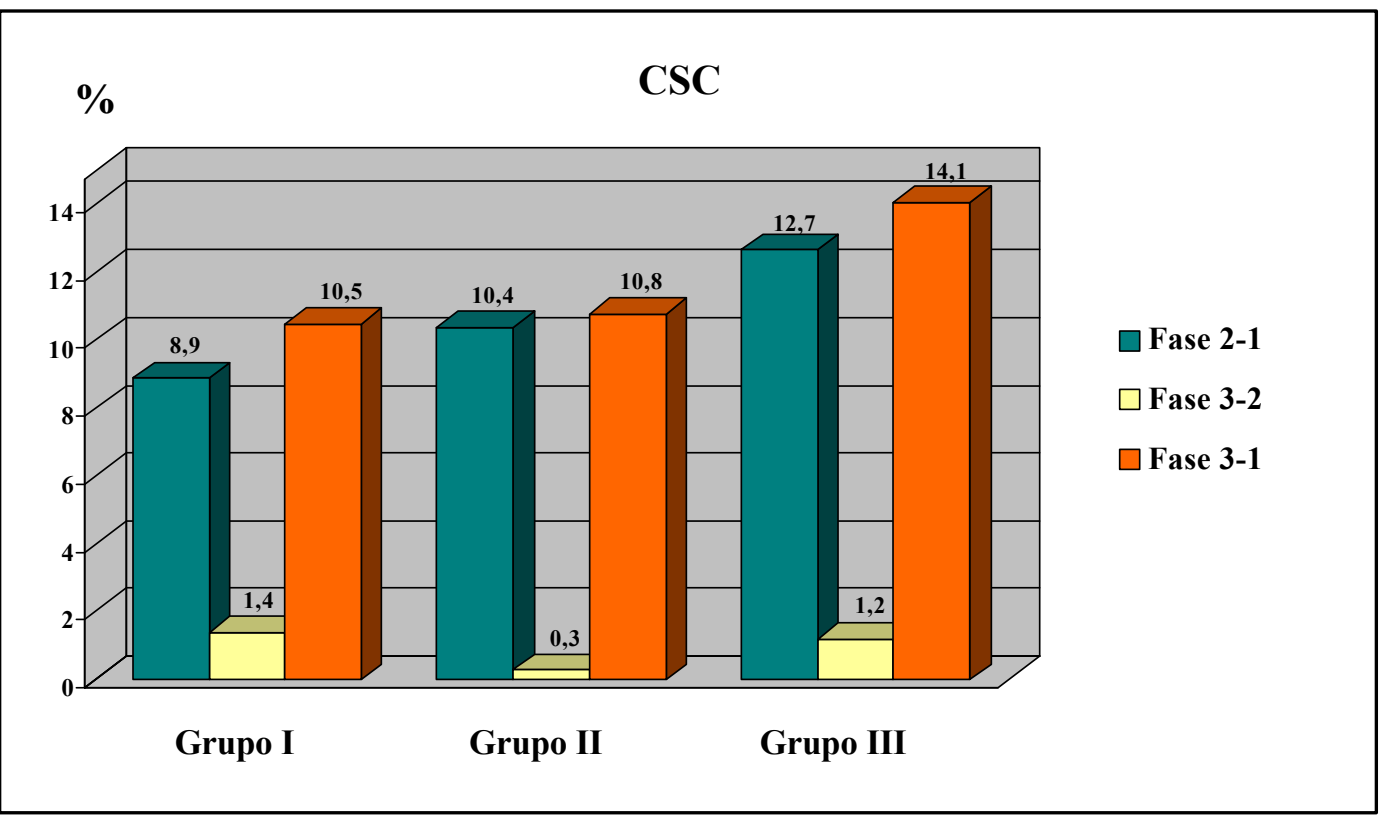

GRÁFICO 5.19 - Variações percentuais observadas para a medida CSC, nos três grupos estudados.

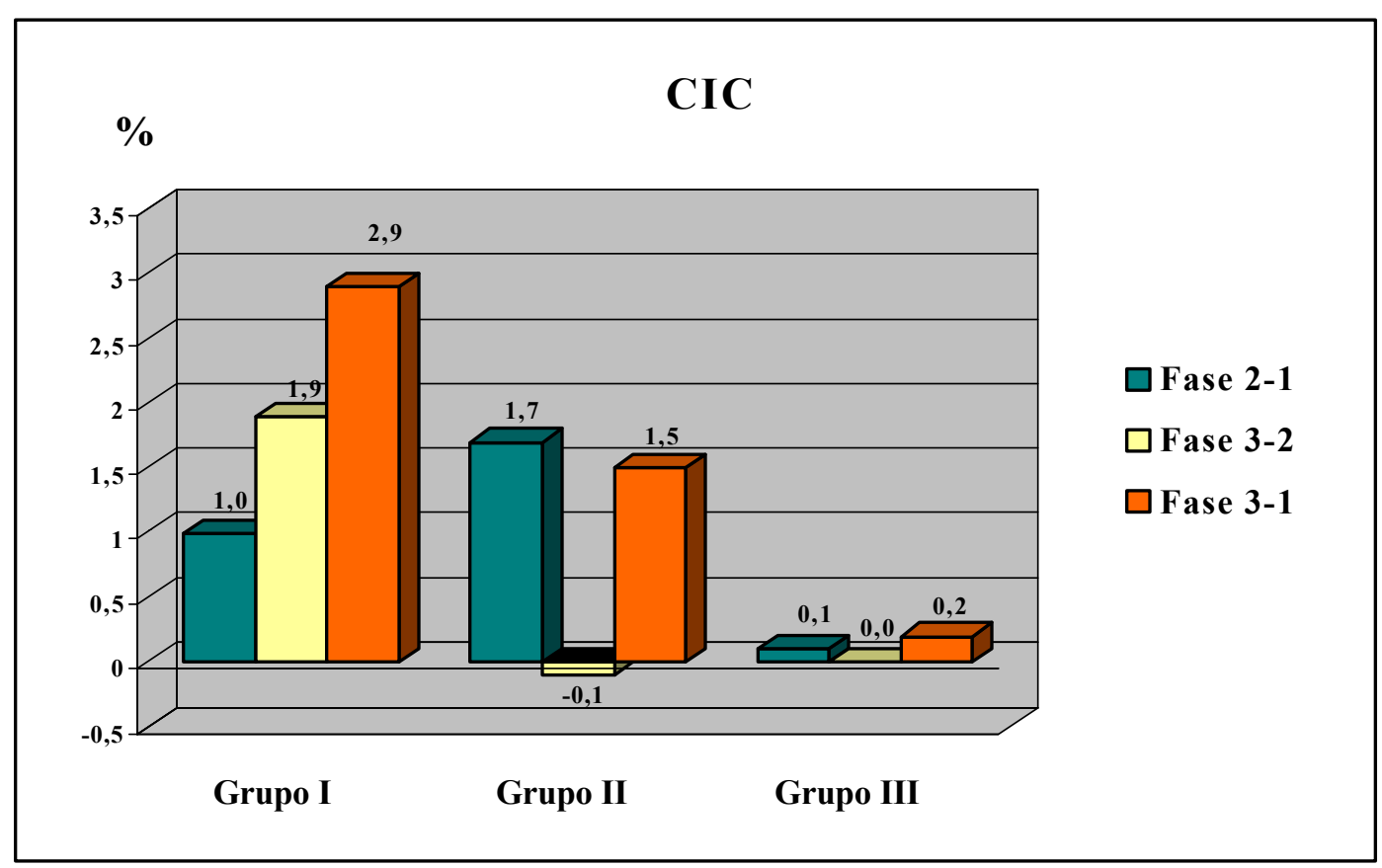

GRÁFICO 5.20 - Variações percentuais observadas para a medida CIC, nos três grupos estudados. 


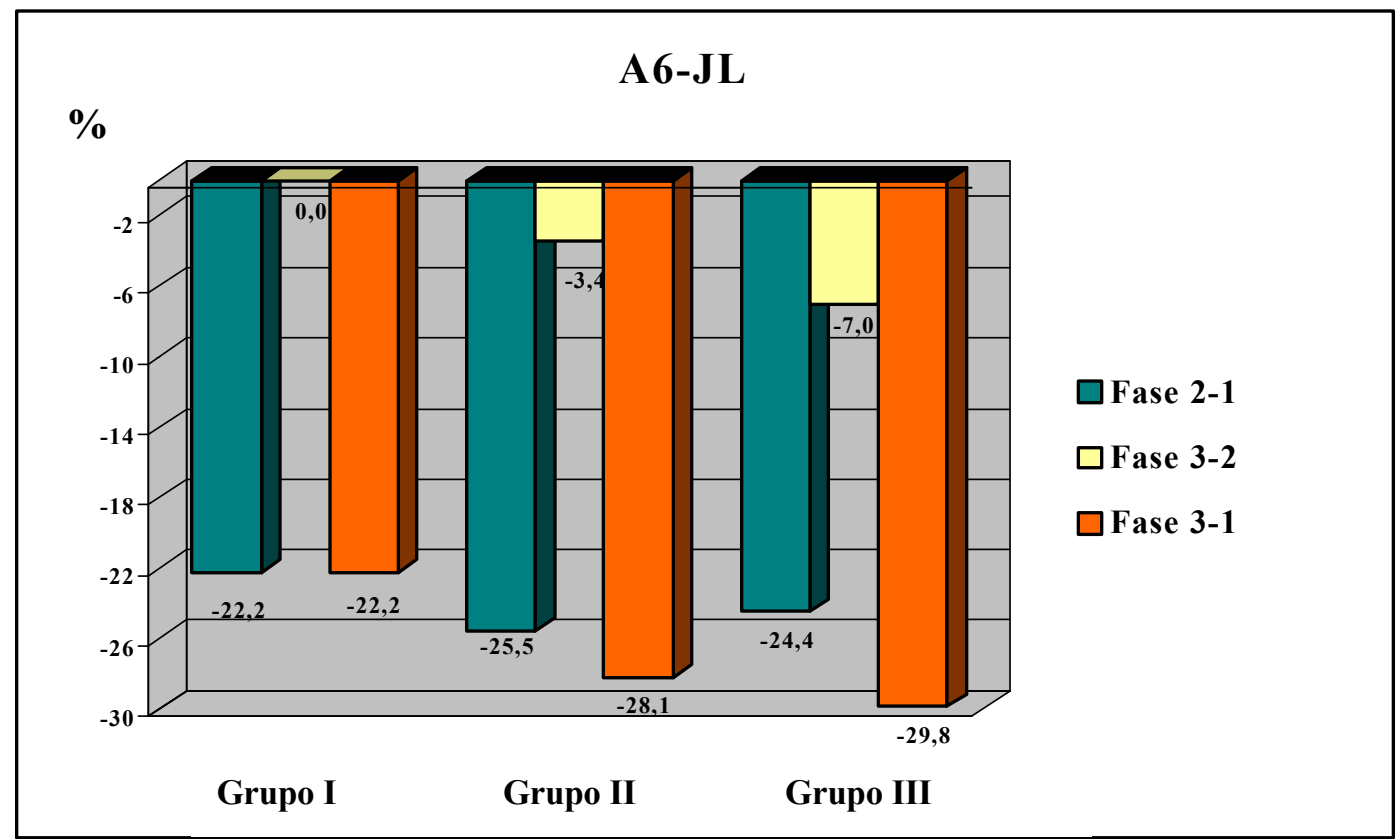

GRÁFICO 5.21 - Variações percentuais observadas para a medida A6JL, nos três grupos estudados.

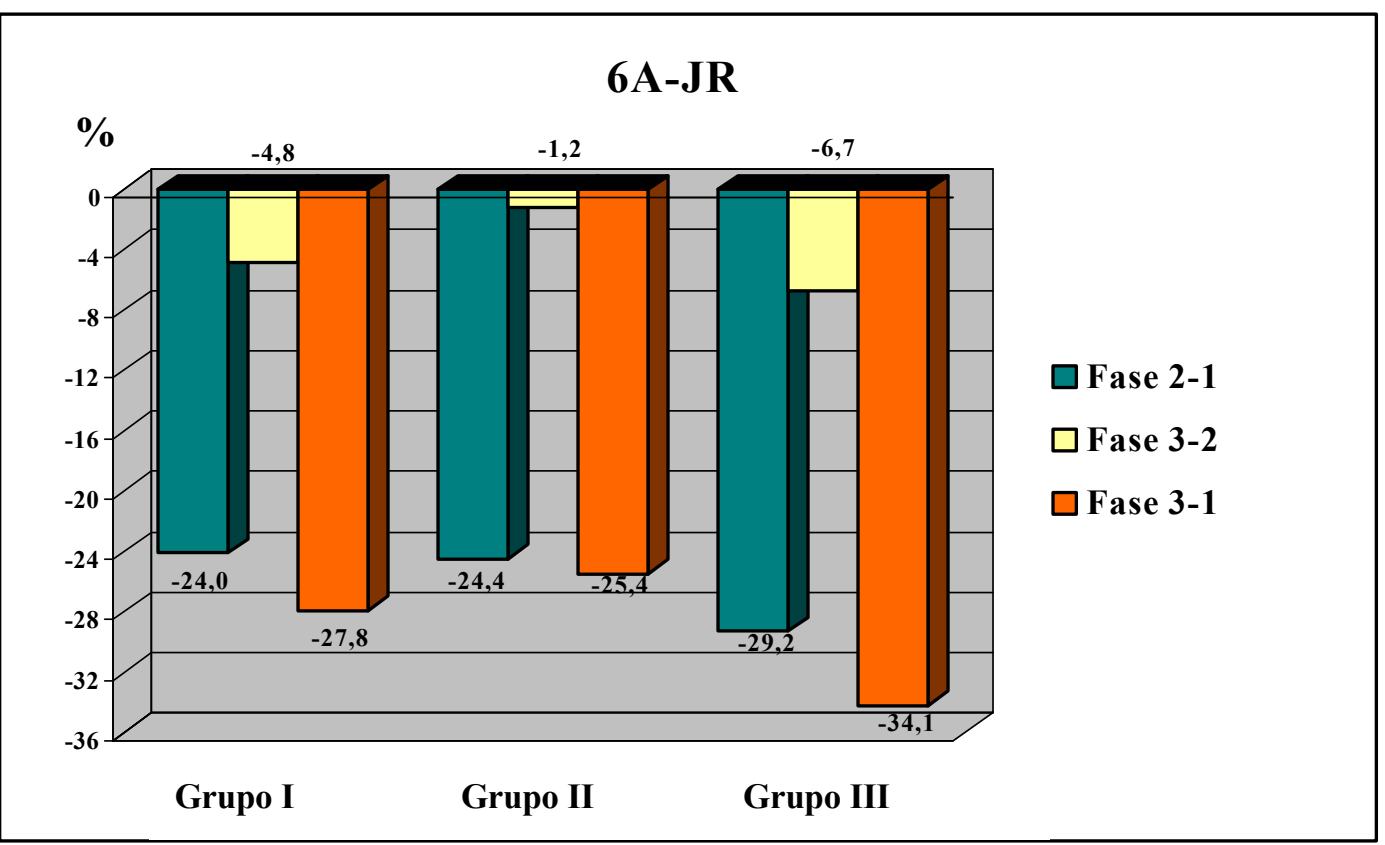

GRÁFICO 5.22 - Variações percentuais observadas para a medida 6AJR, nos três grupos estudados. 


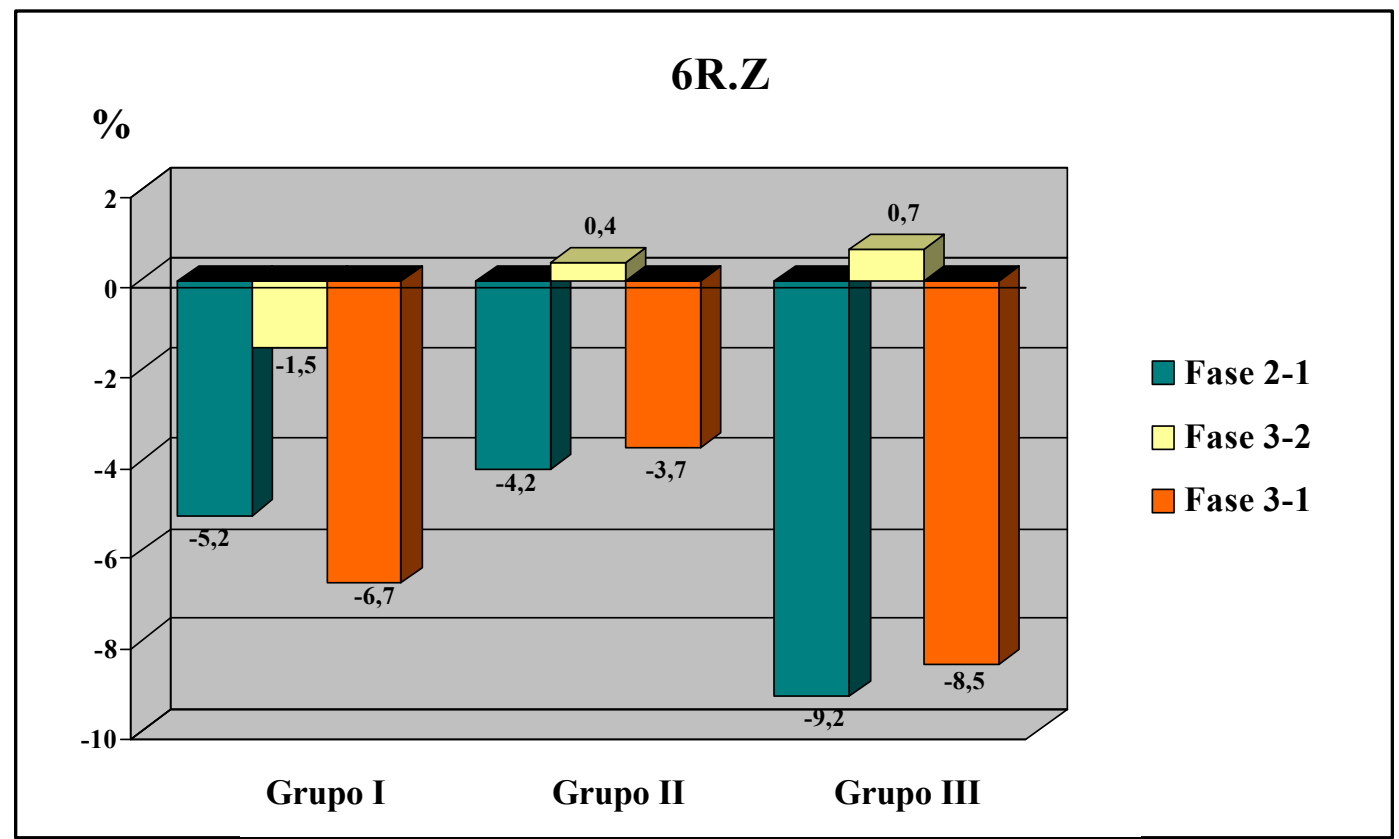

GRÁFICO 5.23 - Variações percentuais observadas para a medida 6R.Z, nos três grupos estudados.
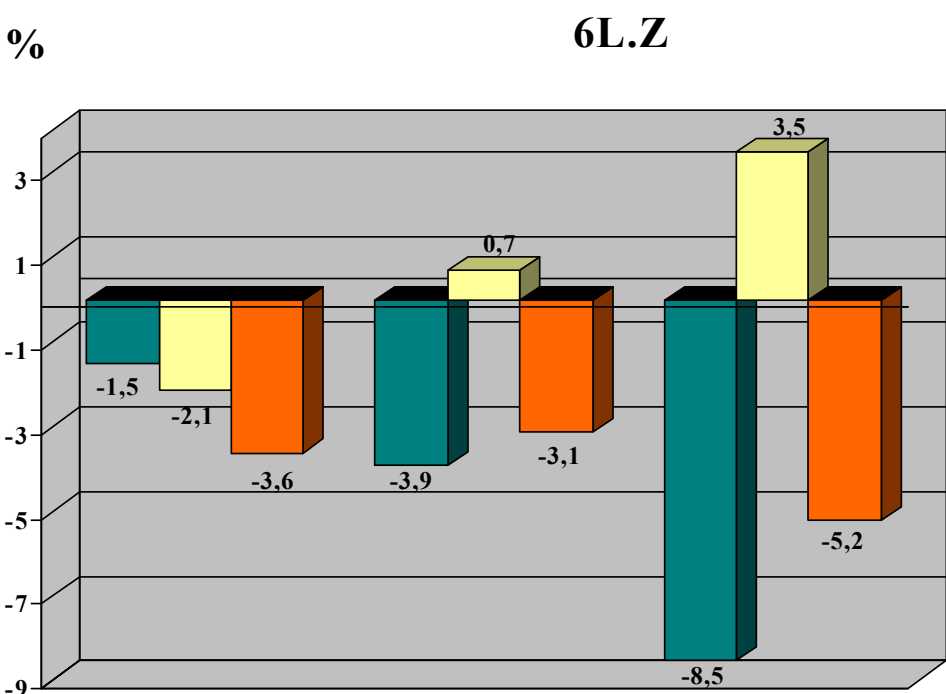

Fase 2-1

$\square$ Fase 3-2

$\square$ Fase 3-1

Grupo I

Grupo II

Grupo III

GRÁFICO 5.24 - Variações percentuais observadas para a medida 6L.Z, nos três grupos estudados. 


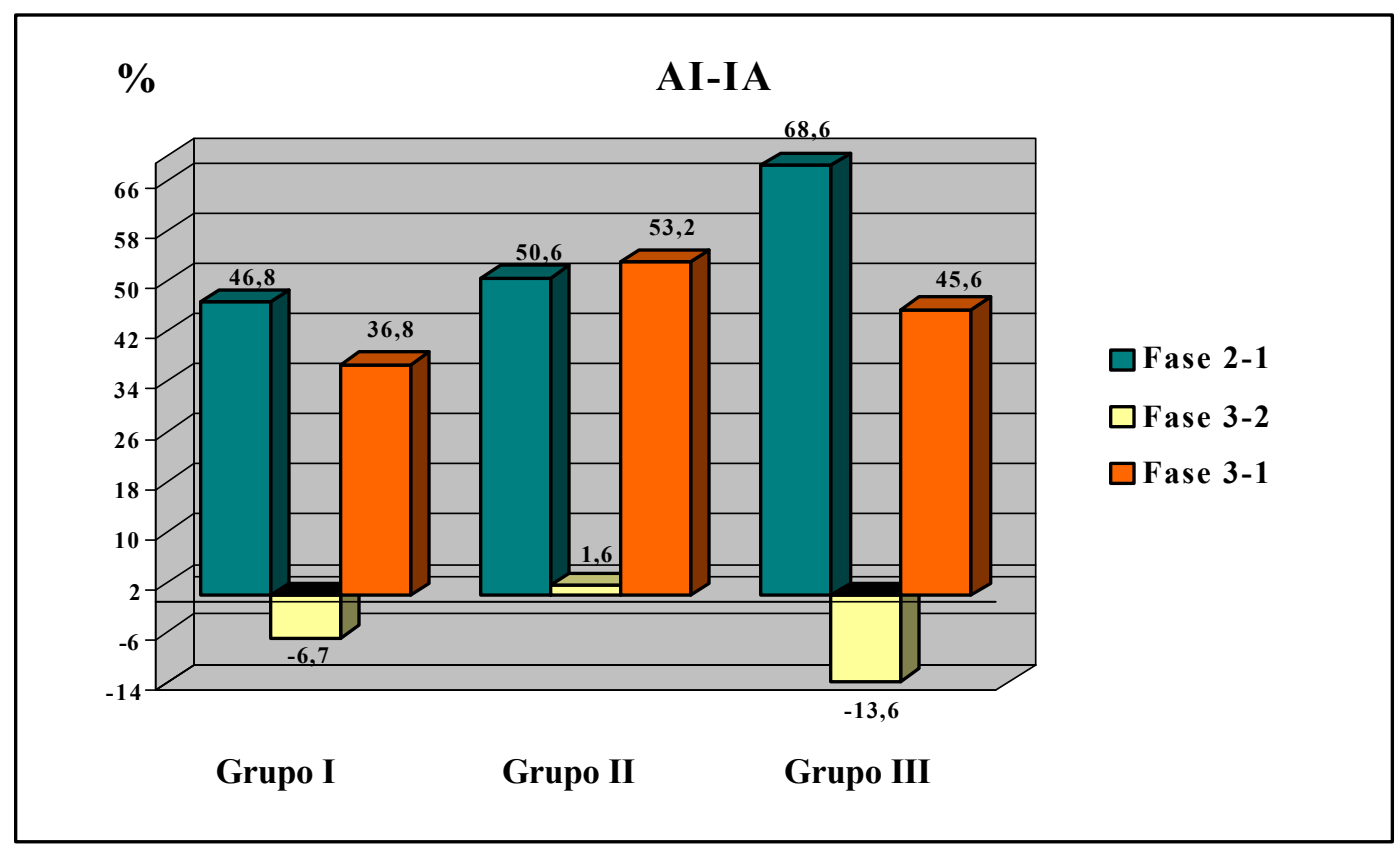

GRÁFICO 5.25 - Variações percentuais observadas para a medida AI-IA, nos três grupos estudados.

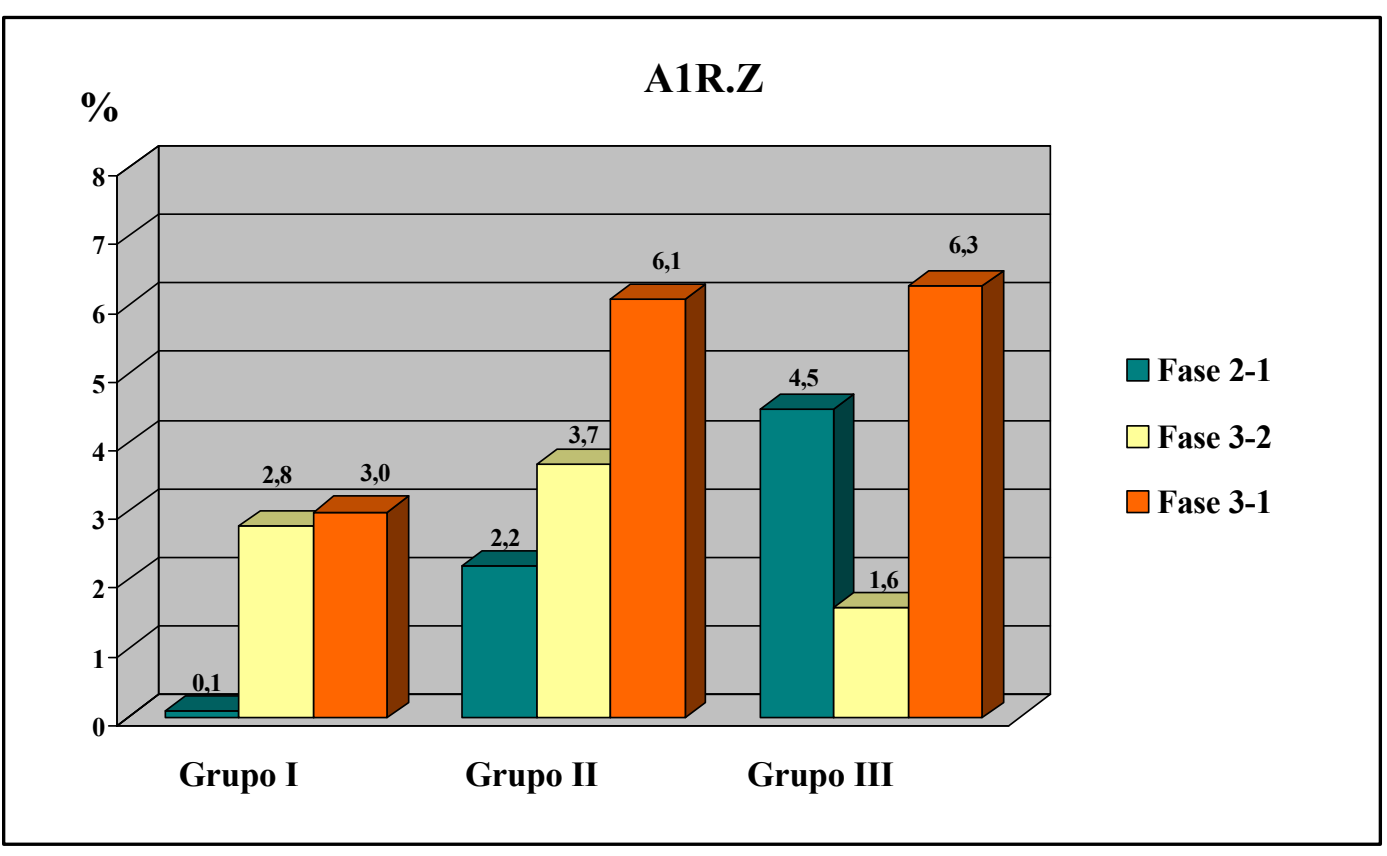

GRÁFICO 5.26 - Variações percentuais observadas para a medida A1R.Z, nos três grupos estudados. 


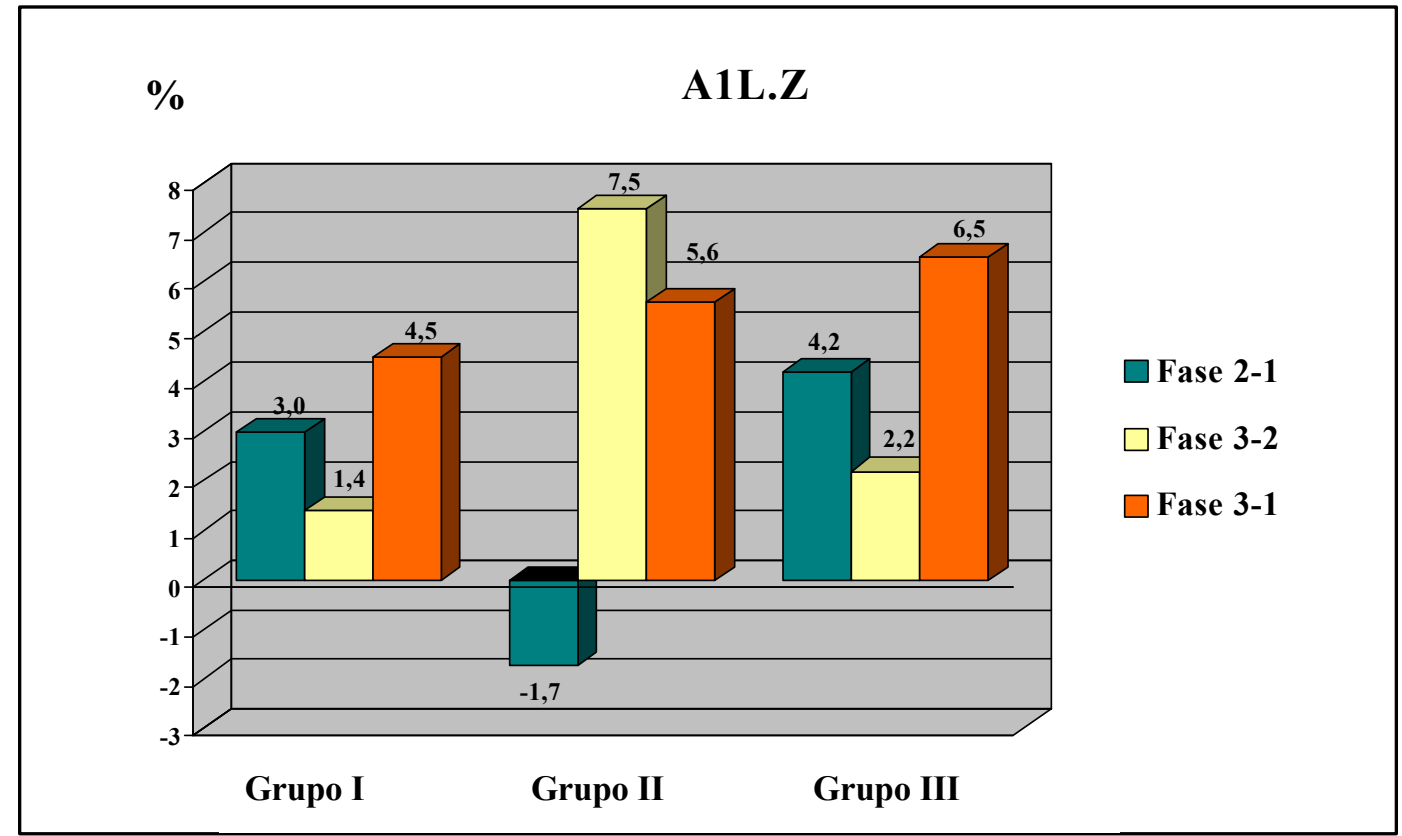

GRÁFICO 5.27 - Variações percentuais observadas para a medida A1L.Z, nos três grupos estudados. 
6. DISCUSSÃO 


\section{DISCUSS ÃO}

A Ortodontia e a Ortopedia Facial visam o restabelecimento das funções bucais normais, como a mastigação, a deglutição, a fonação e a respiração e a obtenção de uma oclusão favorável, com condições periodontais satisfatórias e uma melhoria no perfil facial. Para a obtenção da almejada oclusão "normal", com as seis chaves preconizadas por ANDREWS $^{7}$, deve-se realizar um tratamento nos três planos do espaço, ou seja, nos sentidos transversal, vertical e sagital, na tentativa de se obter um relacionamento harmonioso entre as bases apicais e entre os dentes superiores e inferiores ${ }^{46,22,23}$. A mordida cruzada posterior, uma discrepância transversal, observada em $18 \%$ das crianças brasileiras na fase de dentadura mista ${ }^{22,23,91,92,93}$, pode ser definida como uma relação vestibulolingual incorreta entre os dentes póstero-superiores e inferiores, quando em oclusão cêntrica, ou seja, quando as cúspides vestibulares dos dentes póstero-superiores ocluem nas fossas centrais dos antagonistas inferiores ${ }^{63}$. O diagnóstico da mordida cruzada posterior observando-se apenas a relação de intercuspidação dos dentes posteriores, parece ser duvidoso, uma vez que as discrepâncias sagitais entre as bases ósseas interferem na visualização e na interpretação da real condição transversa do arco superior ${ }^{22}$. Como exemplo, nos casos de discrepâncias esqueléticas de Classe II, a mordida cruzada posterior pode ser camuflada pela má oclusão, mesmo com uma atresia maxilar severa, devido à oclusão do arco dentário inferior em uma região mais posterior do arco superior.

Vários autores preconizam a intervenção precoce desta má oclusão ${ }^{6,12,34,63,64,96}$, uma vez que esta pode ser diagnosticada na fase da dentadura decídua e não se corrige espontaneamente. SILVA FILHO;

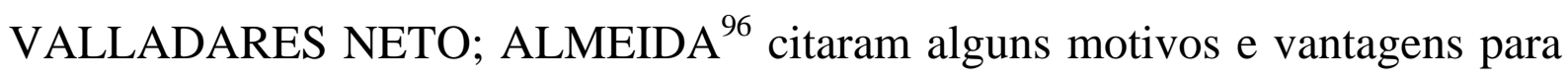


este tratamento precoce : 1) obtenção de respostas mais favoráveis, com aparelhos simplificados, devido à grande bioelasticidade óssea nas crianças; 2) redirecionamento dos germes do dentes permanentes para posições mais favoráveis; 3) proporcionar um melhor relacionamento entre as bases ósseas, permitindo o crescimento e o desenvolvimento normais; 4) eliminação das posições inadequadas da ATM, estabelecendo relações simétricas entre o côndilo e a fossa articular; 5) promover uma trajetória mandibular normal; 6) contribuir para a auto-imagem mais favorável da criança, principalmente nos casos onde há comprometimento estético.

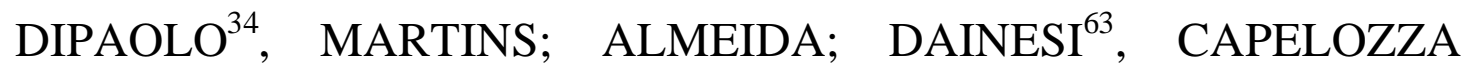
FILHO; SILVA FILHO ${ }^{22,23}$ destacaram a importância do correto diagnóstico das mordidas cruzadas posteriores, uma vez que estas podem ser esqueléticas (deficiência da base apical) ou dentoalveolares (inclinações dentárias indesejáveis). Realiza-se esta diferenciação com o auxílio de observações clínicas (paciente e modelo) e radiográficas (radiografia póstero-anterior), auxiliando na correta definição do tipo de aparelho a ser empregado. Nos casos de deficiência real da maxila, os aparelhos para a ERM, como o Haas, o Hyrax e o expansor colado ${ }^{22,23,96}$, são os mais indicados devido à capacidade de liberação de forças intensas (forças ortopédicas) sobre o palato e/ou sobre a face palatina dos dentes superiores, para a ruptura da sutura palatina mediana e conseqüentemente a obtenção dos efeitos ortopédicos almejados. Nos casos de envolvimento dentoalveolar, preconiza-se o tratamento com a expansão lenta da maxila, ou seja, com aparelhos removíveis (mola Coffin, Splint Coffin e com parafuso expansor) ou fixos (bihélice, quadrihélice e arco em "W") que promovem, quase que em sua totalidade, alterações dentoalveolares. Nos pacientes mais jovens, durante a fase da dentadura decídua, este tipo de 
expansão pode suscitar a abertura da sutura palatina mediana, além dos efeitos ortodônticos, devido à pouca resistência óssea destes indivíduos ${ }^{26,63,96}$.

A expansão rápida da maxila teve o seu primeiro relato em $1860^{8}$, porém este procedimento foi muito questionado e gerou uma grande polêmica entre os ortodontistas americanos, o que culminou no seu esquecimento por um longo período no início deste século. Por outro lado, na Europa, a técnica continuava sendo utilizada e pesquisada por estudiosos como DERICHSWEILER ${ }^{33} \mathrm{e}$ KORKHAUS $^{56}$. Com a grande repercussão dos trabalhos clássicos de $\mathrm{HAAS}^{42-}$ 46, a partir da década de 60, a ERM consolidou-se no meio ortodôntico como um procedimento clínico terapêutico seguro, capaz de restabelecer as dimensões transversais da maxila, aumentando o perímetro do arco ${ }^{1,13}$, em decorrência dos efeitos ortopédicos (abertura da sutura palatina mediana e de outras estruturas faciais adjacentes) e ortodônticos (movimentação vestibular do segmento dentoalveolar póstero-superior).

A partir do primeiro relato feito por ANGELL ${ }^{8}$, muitos autores $5,15,20,29,31,35,42,53,64,66,67,70,72,83,88,102$ propuseram os mais variados tipos de aparelhos para a ERM, descrevendo as suas vantagens e desvantagens, principalmente em relação ao tipo de ancoragem a ser utilizada, na tentativa de se obter resultados mais estáveis e com menores efeitos colaterais para o paciente. HAAS ${ }^{42-46}$, WERTZ $^{111}$, DIPAOLO $^{34}$, BROGAN $^{19}$, SILVA FILHO; CAPELOZZA FILHO ${ }^{90}$, SANTOS PINTO; HENRIQUES ${ }^{82}$, entre outros, preconizaram a utilização do disjuntor dentomucossuportado, para a obtenção de uma ancoragem máxima e de uma maior rigidez do aparelho, favorecendo assim a transferência das forças de ativação às bases ósseas e conseqüentemente permitindo maiores resultados ortopédicos e mais estabilidade da expansão. BIEDERMAN $^{15}$, considerando que o acrílico que cobria o palato poderia causar irritações ao tecido mole, devido à impacção de alimentos, descreveu um 
aparelho mais higiênico, apoiado simplesmente nos dentes (dentossuportado). Com o advento da colagem direta, COHEN; SILVERMAN ${ }^{29}$, divulgaram um aparelho para ERM com cobertura de resina e colado nos dentes pósterosuperiores (dentossuportado). Segundo os autores, este tipo de expansor apresentava algumas vantagens em relação ao Haas, Hyrax e Minne-expander : não existia a necessidade de confecção de bandas; - simplicidade de instalação; potencial de intrusão dos dentes póstero-inferiores; - mais indicado para pacientes com crescimento vertical. Muitos autores, como $\mathrm{HOWE}^{53}$, SPOLYAR ${ }^{102}$, ALPERN; YUROSKO ${ }^{5}$, MOSSAZ; MOSSAZ; MOSSAZ ${ }^{73}$ SARVER; JOHNSTON ${ }^{83}$; VIAZIS ${ }^{109}$, MCNAMARA JÚNIOR; BRUDON ${ }^{66}$, MEMIKOGLU; ISERI; UYSAL ${ }^{69}$, SPILLANE; MCNAMARA JÚNIOR ${ }^{101}$; ASANZA; CISNEROS; NIEBERG ${ }^{9}$ STEIMAN ${ }^{105}$, LÉON et $\mathrm{al}^{59}$, MEMIKOGLU; ISERI ${ }^{67}$, entre outros ${ }^{2,3,70,35}$, descreveram algumas vantagens da utilização deste tipo de expansor com cobertura de acrílico, colado aos dentes superiores (dentossuportado). Entre estas vantagens estão : - fácil confecção devido à ausência de bandas ${ }^{53,102}$; - fácil instalação ${ }^{53,102,66}$; - higiênico, comparável ao $\operatorname{Hyrax}^{53}$ (ausência de suporte mucoso); - pode ser utilizado em pacientes na fase da dentadura decídua e nos casos severos de mau posicionamento dentário ${ }^{53}$, - abertura da mordida, durante a expansão, facilitando a tração reversa da maxila ${ }^{102,66}$; - utilização em casos de expansão assistida cirurgicamente (variação das unidades de ancoragem) ${ }^{102}$, - eliminação das forças horizontais da oclusão, que poderiam interferir na expansão da maxila ${ }^{5}$, - controle vertical durante a $E R M^{5,9,59,66,83,105}$, sendo mais indicado para os pacientes com padrão de crescimento vertical ${ }^{9,59,66,69,83,105}$ e mordidas abertas anteriores ${ }^{9,69,109}$; - pode-se associar ganchos na altura dos caninos, para o uso da máscara facial, no tratamento da Classe III ${ }^{5,66}$. 
Muitos estudos microscópicos ${ }^{28,51,76,103104}$ e radiográficos ${ }^{4,9,19,28,32,42,43,56-}$ $58,69,83,94,97,99,112,113$ (telerradiografia em norma frontal e lateral) demonstram as alterações decorrentes do procedimento de ERM e algumas mudanças provocadas por um novo posicionamento dentoesquelético. Uma das principais características deste procedimento é a liberação de forças intensas, que podem oscilar entre 1000 a 3000 gramas em uma única ativação e acumular mais de 7000 gramas em ativações consecutivas ${ }^{23,114}$, consideradas como forças ortopédicas, que promovem alterações esqueléticas e dentoalveolares. BARBER; SIMS $^{10}$, relataram reabsorções radiculares nas superfícies vestibulares de todos os dentes de ancoragem, porém, com a remoção da força, existe a predominância do processo reparador nas áreas afetadas. A abertura da sutura palatina mediana e o envolvimento de outras suturas faciais, como as suturas frontonasal, zigomaticomaxilar e zigomaticotemporal são considerados como resultados ortopédicos da expansão. Em uma visão horizontal a abertura da sutura palatina mediana apresenta-se no formato triangular, com a base voltada para a região anterior e vértice localizado na união dos ossos palatinos $^{21,111}$. No plano frontal, a abertura da sutura palatina mediana demonstra a mesma configuração geométrica, com o fulcro localizado próximo à sutura frontonasal e com a base voltada para a cavidade bucal (área de menor resistência óssea) $)^{32,42,43,94,111,113}$. Esta abertura sutural pode ser constatada clinicamente pelo aparecimento de um diastema entre os incisivos centrais superiores $^{42,43,71,94,95,114}$, caracterizado pela divergência apical e convergência das coroas, que se fecha após alguns meses, em decorrência da maior aproximação das coroas, estimulada pelas fibras transeptais. Observa-se uma tentativa de retorno destes dentes às suas inclinações iniciais, porém, segundo SILVA FILHO; PINHEIRO JÚNIOR; CAVASSAN ${ }^{95}$, mesmo após 12 meses, a angulação interincisivos permanece diferente da original. VARDIMON et al ${ }^{107}$ 
indicaram um padrão de remineralização (fechamento) póstero-anterior da sutura palatina mediana, semelhante ao "fechamento de um zíper". Apesar da grande força exercida, que ultrapassa o limite ideal para a movimentação dentária induzida, observam-se algumas alterações dentoalveolares características, como a inclinação dos processos alveolares, a vestibularização e a pequena extrusão dos dentes de ancoragem. Esta alteração no longo eixo dos dentes posteriores apresenta-se altamente recidivante ${ }^{58,61,82}$, necessitando de uma sobrecorreção de 2 a $3 \mathrm{~mm}$ do segmento póstero-superior ${ }^{42-46,70,82,90}$, para a obtenção de um resultado final satisfatório.

Ainda no plano frontal, relata-se o aumento da largura

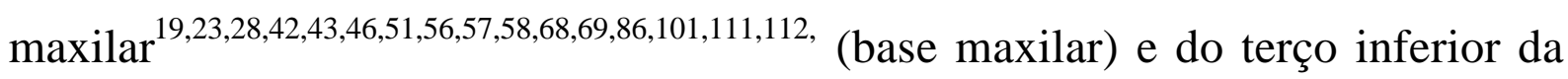
cavidade nasal ${ }^{19,42,43,46,48,50,56,57,58,65,72,94,111,112,113}$, aumentando assim a permeabilidade nasal, o aumento nas distâncias intercaninos e intermolares

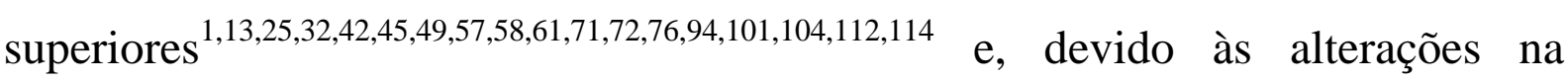
oclusão e ao restabelecimento do equilíbrio muscular, os dentes inferiores apresentam uma discreta verticalização, ${ }^{1,2,32,40,42,45,46,51,81,112}$. A idade dos pacientes está diretamente relacionada com a magnitude dos efeitos ortopédicos e ortodônticos, ou seja, nos pacientes mais velhos, onde a resistência óssea apresenta-se maior, serão observados maiores efeitos ortodônticos, em detrimento dos efeitos ortopédicos ${ }^{58,111,112,114}$.

A abertura da sutura palatina mediana, descrita anteriormente, provoca certas alterações na maxila e conseqüentemente nas estruturas contíguas, muito discutidas na literatura. Alguns autores relatam um deslocamento maxilar para frente e para baixo ${ }^{42,43,111,112}$, porém outros estudos descrevem apenas um deslocamento inferior da maxila, sem qualquer alteração no sentido sagital $^{4,21,23,55,97,99}$. SILVA FILHO, VILLAS BOAS; CAPELOZZA FILHO ${ }^{97}$ e SILVA FILHO et al $^{99}$ concluíram que, independente da faixa etária ou do 
desenvolvimento oclusal, a maxila não é deslocada anteriormente, pelo menos com constância, durante a ERM. Como efeito do deslocamento inferior da maxila, da extrusão e vestibularização dos dentes de ancoragem, da inclinação dos processos alveolares e da sobrecorreção do segmento posterior, a mandíbula sofre uma rotação para baixo e para trás ${ }^{4,21,32,42,49,55,97,99,111}$. Ao girar no sentido horário, a mandíbula induz alterações cefalométricas significativas, como o aumento da altura facial ântero-inferior, do eixo "y" de crescimento e do ângulo do plano mandibular, além de uma pequena tendência de abertura da mordida. Estas mudanças seriam consideradas desfavoráveis para os pacientes com crescimento excessivamente vertical e com mordida aberta anterior ${ }^{34,62,77,79,100}$, porém, verificando os estudos realizados com amostras analisadas a longo prazo $^{4,24,27,79,108}$, pode-se concluir que estas alterações cefalométricas, observadas logo após a expansão rápida da maxila, constituem fenômenos temporários, e portanto, não requerem precauções quando da aplicação deste procedimento em pacientes com padrão de crescimento predominantemente vertical.

Com o propósito de avaliar se existiriam diferenças nas respostas dentoesqueléticas de três tipos de aparelhos para a ERM, que utilizam ancoragem diferentes, realizou-se um estudo radiográfico (radiografia pósteroanterior) em três grupos de pacientes, tratados com o expansor tipo Haas modificado (dentomucossuportado), o expansor tipo Hyrax modificado (dentossuportado com bandas) e o expansor colado (dentossuportado, com uma camada de resina acrílica). Este trabalho segue uma linha de pesquisa iniciada por MAZZIEIRO ${ }^{65}$ e KAWAKAMI ${ }^{55}$. A descrição mais detalhada da amostra e dos aparelhos utilizados encontra-se no capítulo de Material e Métodos.

Existiram algumas dificuldades para a obtenção de uma análise que determinasse as alterações promovidas pelos aparelhos, uma vez que a maioria das análises em norma frontal descritas na literatura, como as de MULICK ${ }^{75}$, 
GRUMMONS; COPPELLO ${ }^{39}$ e LETZER; KRONMAN ${ }^{60}$, são utilizadas para a avaliação das assimetrias faciais. Porém, a análise descrita por GUGINO ${ }^{41}$, em 1977, que apresentou os padrões de normalidade, desvios-clínicos e incrementos anuais, provenientes do crescimento, para algumas medidas em norma frontal, nos pareceu satisfatória. Além disto, SATO $^{85}$, em 1982, determinou os padrões de normalidade de algumas destas medidas para pacientes brasileiros, de ambos os sexos, na faixa etária de 12 a 17 anos, com oclusão normal e que não tinham sido submetidos ao tratamento ortodôntico. Portanto, o método cefalométrico utilizado na avaliação das alterações dentoesqueléticas decorrentes da $E R M$, baseou-se principalmente nos relatos de GUGINO $^{41}$ e SATO $^{85}$.

Para facilitar a visualização e a interpretação dos resultados obtidos com o auxílio das análises estatísticas, ilustrados no capítulo anterior, discutiremos separadamente as variáveis analisadas em norma frontal, nos três grupos submetidos à $E R M$, assim como o erro do método empregado :

6.1) Erro do Método

6.2) Distância NC-CN - Largura da Cavidade Nasal

6.3) Distância JL-JR - Largura Maxilar

6.4) Comportamento dos molares de ancoragem

6.5) Comportamento dos primeiros molares inferiores

6.6) Comportamento dos incisivos centrais superiores

6.7) Comportamento da sobremordida e da AFAI

6.8) Considerações finais 


\section{1) Erro do Método}

$\mathrm{O}$ estudo das alterações dentoesqueléticas decorrentes da $E R M$ foi realizado utilizando-se a telerradiografia em norma frontal (radiografia ânteroposterior), uma vez que concordamos com MULLICK ${ }^{75}$, que afirmou que esta é a única maneira disponível para se verificar o crescimento e as alterações transversais da face e com DIPAOLO ${ }^{34}$, SATO; VIGORITO; CARVALHO, ${ }^{86}$ MARTINS; ALMEIDA; DAINESI ${ }^{63}$, MAZZIEIRO $^{65}$, SILVA FILHO; MONTES; TORELLY ${ }^{94}$, BETTS et $\mathrm{al}^{14}$, MEMIKOGLU; ISERI ${ }^{68} \mathrm{e}$ CAPELOZZA FILHO; SILVA FILHO ${ }^{22,23}$ que comentaram que este tipo de radiografia apresenta-se como um método eficiente para o correto diagnóstico das mordidas cruzadas posteriores e para a visualização e a diferenciação dos efeitos ortopédicos e ortodônticos decorrentes da ERM.

Apesar das vantagens deste tipo de radiografia para tal avaliação, existem algumas desvantagens neste método radiográfico, como a dificuldade de obtenção de pontos de referência estáveis ${ }^{80}$ e principalmente a grande sobreposição de imagens das estruturas craniofaciais $^{84}$, dificultando a delimitação precisa de certas estruturas anatômicas e a obtenção das medidas cefalométricas para a análise. Uma das partes mais críticas é a região das raízes dos dentes superiores, pois estas apresentam-se indefinidas, devido à grande sobreposição das imagens radiográficas nesta área. Contudo, a região das coroas, principalmente as superfícies vestibular e oclusal, apresentam relativa facilidade de visualização, sendo delimitadas com o auxílio de gabaritos específicos para uma padronização dos traçados ${ }^{65}$. A utilização deste tipo de gabarito pode determinar posições imprecisas das raízes dos molares superiores e influenciar os resultados finais, porém este demonstra-se como o método mais confiável para a delimitação destas estruturas. 
Além da sobreposição das imagens radiográficas, GOLDREICH et $\mathrm{al}^{38}$, em 1998, citaram mais alguns fatores, que somados, podem causar sensíveis erros na análise final das telerradiografias : - projeção do objeto no filme (fator de magnificação das radiografias); - erro na localização e no registro dos pontos cefalométricos, concordando com HOUSTON ${ }^{52}$; - erros na realização dos traçados e nas mensurações.

$\mathrm{Na}$ tentativa de demonstrar a confiabilidade dos traçados cefalométricos, das medidas obtidas e conseqüentemente dos resultados, apesar das dificuldades relatadas, realizou-se a avaliação da metodologia empregada, para a obtenção do erro do método. Foram retraçadas e medidas novamente, como preconizado por HOUSTON $^{52}$, JANSON $^{54}$ e SILVA ${ }^{89}$, as radiografias de cinco pacientes do Grupo III (expansor colado), selecionados aleatoriamente, após um período mínimo de dois meses, para a verificação do erro intra-examinador. Foram utilizadas as radiografias nos três tempos (pré-expansão, pós-expansão e póscontenção), totalizando 15 radiografias. Aplicou-se o teste "t" pareado (variáveis dependentes), para a verificação do erro sistemático e a fórmula de DAHLBERG $^{30}$, para estimar a ordem de grandeza dos erros casuais.

A tabela 5.28 (p.137) demonstra que os maiores erros casuais foram observados nas variáveis que analisaram as alterações angulares dos molares superiores (6R.Z e 6L.Z), devido à dificuldade de identificação precisa das estruturas, como descrito anteriormente. Entre as medidas lineares, a AFAI demonstrou maior variação, em decorrência da imprecisão na delimitação do ponto espinha nasal anterior. Estes erros casuais advêm das dificuldades na identificação dos pontos cefalométricos e também devido à imprecisão nas definições de certos pontos ${ }^{52,54}$.

Os resultados da avaliação dos erros sistemáticos, observados na tabela 5.29 (p.138), demonstram que dentre as 15 variáveis analisadas nos três tempos 
do estudo, apenas uma (AFAI pré-expansão) apresentou diferença estatisticamente significante. Estes erros alertam para a existência de deficiências na padronização dos métodos, em uma ou várias etapas, tais como o traçado dos cefalogramas, a demarcação dos pontos, o traçado das linhas e planos e as mensurações ${ }^{87}$.

Diante do exposto, conclui-se que os erros casuais mais elevados, já eram esperados, devido à dificuldade de observação e delimitação das estruturas envolvidas (raízes dos molares superiores). Além disto, os erros sistemáticos apresentaram-se estatisticamente significantes em apenas uma variável, tornando lícito afirmar que a precisão das medidas foi mantida dentro de parâmetros aceitáveis para a pesquisa, sem qualquer repercussão sobre os resultados e conclusões desta investigação.

Com o objetivo de determinar a confiabilidade de se empregar os valores obtidos por MAZZIEIRO ${ }^{65}$, para o Grupo I (Haas modificado) e para o Grupo II (Hyrax modificado) e verificar os possíveis erros interexaminadores, foram retraçadas 12 radiografias escolhidas aleatoriamente e as medidas lineares e angulares obtidas foram comparadas com as deste autor ${ }^{65}$, utilizando o teste " $\mathrm{t}$ " para amostras dependentes. A Tabela 5.30 (p.140) ilustra os resultados desta comparação, demonstrando uma diferença estatisticamente significante apenas para a medida 6R.Z, comprovando a dificuldade na delimitação da porção radicular dos primeiros molares superiores. As outras medidas não apresentaram diferenças estatisticamente significantes, demonstrando que os dois examinadores estavam calibrados, o que validou a utilização dos valores obtidos pelo $1^{\mathrm{o}}$ examinador ${ }^{65}$ para a realização deste estudo comparativo. Como MAZZIEIRO $^{65}$ não utilizou a medida linear AFAI em sua pesquisa, esta foi obtida para os três grupos estudados, não havendo a necessidade da realização da verificação do erro interexaminadores para esta variável. 


\section{2) Distância NC-CN (Largura da cavidade nasal)}

A ERM provoca grandes alterações da sutura palatina mediana e pequenas mudanças das suturas frontonasal, zigomaticomaxilar e zigomaticotemporal ${ }^{6}$, caracterizadas histologicamente pelo aumento da atividade celular ${ }^{28,51,76,103,104}$.Juntamente com estas alterações ortopédicas, ocorre um aumento significante na largura da cavidade nasal $^{19,42,43,46,48,50,56,57,58,65,68,72,94,111,112,113}$ e uma redução na resistência nasal respiratória. Apesar de ser um dos efeitos da terapia expansionista, a melhoria na capacidade respiratória em pacientes com obstruções nasais, não deve ser considerada como uma indicação para tal procedimento. HARTGERINK; VIG; $\mathrm{ABBOT}^{48}$, observaram uma grande variação individual nos valores da resistência nasal respiratória nas fases pré-expansão, pós-expansão e póscontenção, de indivíduos submetidos a $E R M$, concluindo que esta técnica não demonstra confiabilidade como um método para a redução da resistência respiratória nasal em todos os pacientes.

Apesar de não ser um dos principais objetivos da $E R M$, o aumento na largura da cavidade nasal foi analisado e os valores lineares médios préexpansão, pós-expansão e pós-contenção dos três grupos, estão dispostos nas Tabelas 5.1 a 5.3. (p110 a 112) e ilustrados nos Gráficos 5.1 (p.142) e 6.1.As medidas realizadas na fase pré-expansão, demonstram valores médios inferiores, quando comparadas às determinadas por $\mathrm{SATO}^{85}$. Os valores finais, ou seja, após a fase de contenção, se aproximaram dos valores normativos, indicando uma influência da expansão sobre a largura inferior da cavidade nasal e uma tendência de normalização das dimensões nasais ${ }^{65,85}$. Os valores médios encontrados por $\mathrm{SATO}^{85}$ para o sexo masculino foram de $31,17 \mathrm{~mm}$, com um desvio-padrão de 2,28 mm e para o sexo feminino de $30,0 \mathrm{~mm}$, com desvio- 
padrão de 2,56 $\mathrm{mm}$. Os valores finais, obtidos nesta amostra estudada, também se aproximaram dos encontrados por GUGINO $^{41}$, em pacientes com idade média de 14 anos e meio, onde esta variável apresentava um valor médio de 29,2 mm, com um desvio-padrão de 2,0 mm, para ambos os sexos.

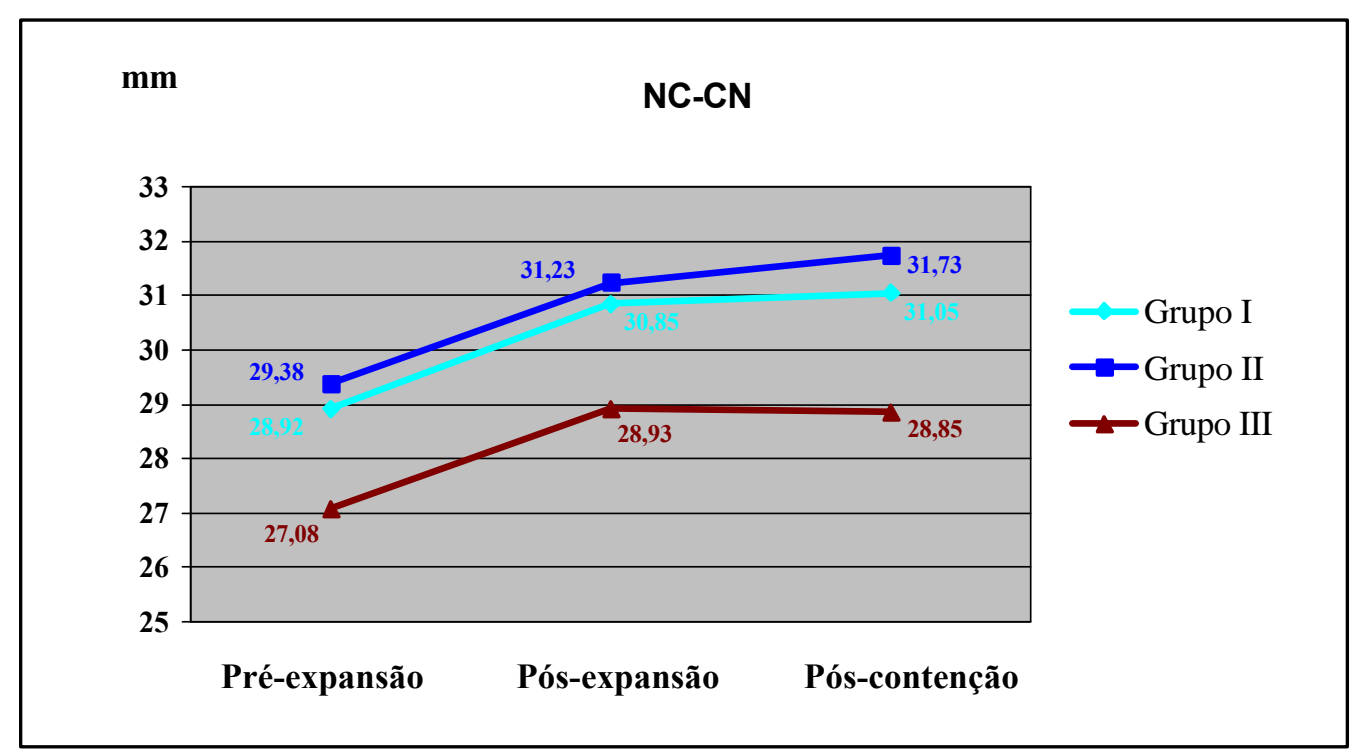

GRÁFICO 6.1 - Valores médios observados para a variável NC-CN

Os resultados encontrados para a distância NC-CN, ilustrados nas tabelas 5.4 a 5.12 (p.113 a 121), indicam um aumento estatisticamente significante nos valores, da fase pré-expansão para a pós-expansão, nos três grupos analisados, ou seja, houve um aumento na largura inferior da cavidade nasal com a ERM, concordando com os achados de $\mathrm{KREBS}^{57,58}$, KORKHAUS ${ }^{56}$ HAAS $^{42,43,46}$, MOOS $^{72}$, WERTZ ${ }^{111}$, WHITE ${ }^{113}$, HERSHEY; STEWART; WARREN ${ }^{50}$, BROGAN $^{19}$, WERTZ; DRESKIN ${ }^{112}$, HARTGERINK; VIG; ABBOT ${ }^{48}$, MEMIKOGLU; ISERI; UYSAL ${ }^{69}$, MAZZIEIRO ${ }^{65}$, SILVA FILHO; MONTES; TORELLY ${ }^{94}$, CAPELOZZA FILHO; SILVA FILHO ${ }^{23}$, MEMIKOGLU; ISERI $^{68}$. Durante o período de contenção, nenhum dos três grupos apresentou alterações estatisticamente significantes, demonstrando a estabilidade na 
expansão, apesar de um pequeno aumento nos Grupos I e II e uma discreta diminuição no Grupo III, correspondendo aos trabalhos de $\mathrm{HAAS}^{46}, \mathrm{KREBS}^{58}$, HERSHEY; STEWART; WARREN ${ }^{50}$, WERTZ; DRESKIN ${ }^{112}$, HARTGERINK; VIG; ABBOT ${ }^{48}$, MAZZIEIRO $^{65}$ e MEMIKOGLU; ISERI ${ }^{68}$. Comparando-se as alterações entre o período pré-expansão e o período póscontenção, os valores apresentaram-se estatisticamente significantes para os três grupos, corroborando os outros achados descritos anteriormente.

O gráfico 5.16 (p.150) demostra as variações percentuais observadas para a medida NC-CN, com o objetivo de facilitar a visualização da magnitude das alterações ocorridas. Como resultado imediato da expansão (fase pré-expansão até a fase pós-expansão), os grupos tiveram aumentos percentuais semelhantes, sendo 6,6 \% para o Grupo I, 6,2 \% para o Grupo II e 6,8 \% para o Grupo III. Durante o período de contenção, apesar de não existir diferenças estatisticamente significantes entre os grupos, estes não apresentaram respostas totalmente iguais. Nos Grupos I e II, os valores apresentaram um aumento de 0,6 $\%$ e $1,6 \%$ respectivamente. No Grupo III, este valor apresentou um decréscimo percentual insignificante de $-0,2 \%$. Baseados nestas informações, conclui-se que o resultado final da $E R M$ sobre a cavidade nasal foi ligeiramente menor no Grupo III, com aumento final de 6,5 \%, sendo que para o Grupo I o aumento foi de $7,3 \%$ e para o Grupo II de 7,9\%. Apesar disto, as diferenças não apresentaram significância estatística.

As Tabelas 5.13 a 5.15 (p.122 a 124) ilustram as comparações entre os incrementos médios das variáveis analisadas nos três grupos e nos três períodos do estudo (pré-expansão, pós-expansão e pós-contenção). Estas tabelas demonstram a ausência de diferenças estatisticamente significantes para a variável NC-CN entre os três grupos, portanto, independente do tipo de ancoragem utilizada, os efeitos sobre a cavidade nasal foram semelhantes. 


\section{3) Distância JL-JR (Largura da maxila)}

A distância linear entre os pontos JL e JR determina a largura maxilar, que geralmente é aumentada durante a ERM, principalmente pela abertura da sutura palatina mediana e pelo afastamento lateral das hemimaxilas, em resposta à aplicação de forças intensas de expansão ${ }^{28,103}$.

Esta medida, observada nas telerradiografias em norma frontal, apresentase como um ótimo parâmetro para o diagnóstico das mordidas cruzadas posteriores com envolvimento esquelético e para a visualização das alterações transversais da base maxilar após a terapia expansionista. Utilizando-se os valores normativos descritos por GUGINO $^{41}$ ou SATO $^{85}$, pode-se comparar os valores iniciais pré-expansão e observar o grau de atresia maxilar e a necessidade da realização da $E R M$, auxiliando no diagnóstico e no plano de tratamento. Segundo GUGINO ${ }^{41}$, a norma clínica, para ambos os sexos é de 64,9 mm (desvio padrão de 3,0 mm) e para SATO ${ }^{85}$, o valor normativo médio para o sexo masculino é de $67,25 \mathrm{~mm}$ (desvio padrão de $3,38 \mathrm{~mm}$ ) e para o sexo feminino de 63,72 mm (desvio-padrão de 2,19 mm).

Os valores médios pré-expansão, pós-expansão e pós-contenção para esta variável, observada nos três grupos, estão dispostos nas Tabelas 5.1 a 5.3. (p.110 a 112) e ilustrados nos Gráficos 5.2 (p.142) e 6.2. As medidas realizadas na fase pré-expansão demonstram valores médios inferiores, quando comparadas às determinadas por GUGINO ${ }^{41}$ e SATO $^{85}$, demonstrando a necessidade de expansão do arco superior. A média final dos valores encontrados para os três grupos, ou seja, após o término da fase de contenção, se aproximaram dos valores normativos descritos por GUGINO $^{41}$ e daqueles instituídos por SATO ${ }^{85}$ para o sexo feminino, representando uma normalização das dimensões transversais da maxila. 


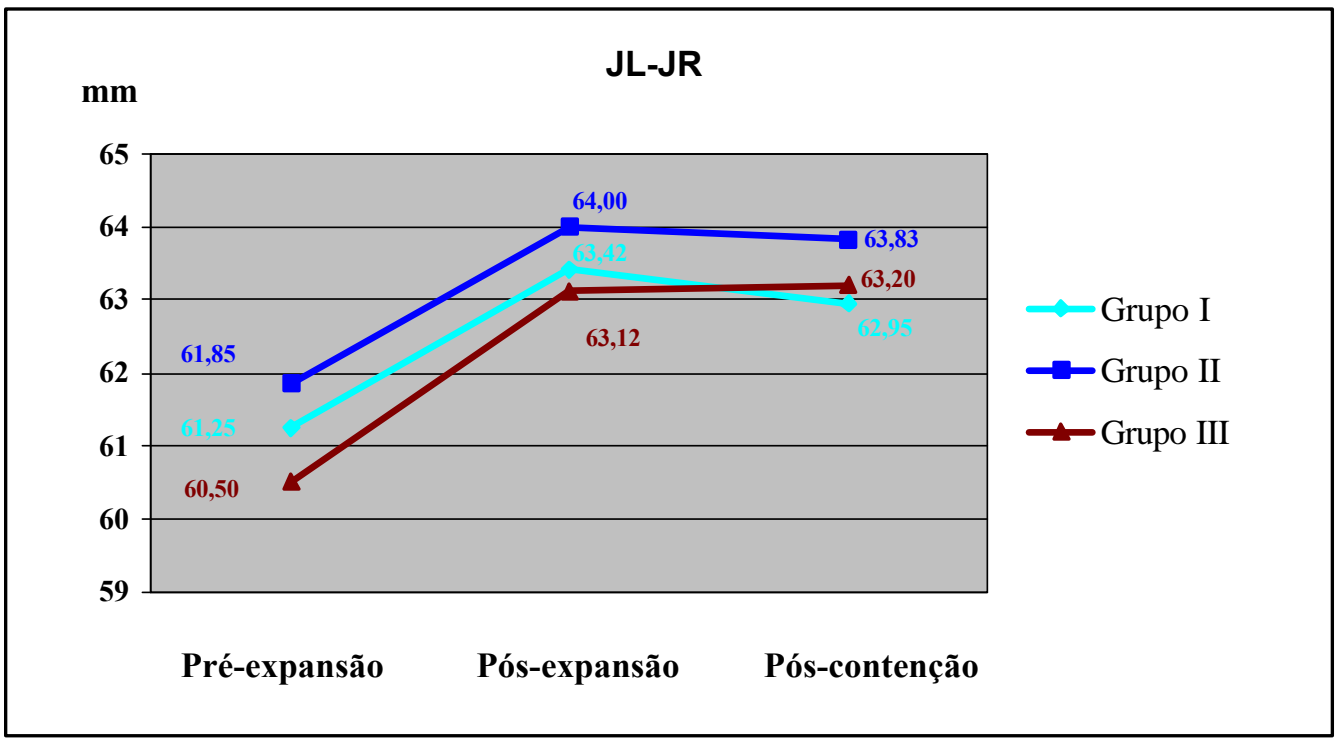

GRÁFICO 6.2 - Valores médios observados para a variável JL-JR

Os resultados encontrados para a distância JL-JR, ilustrados nas tabelas 5.4 a 5.12 (p.113 a 121), indicam um aumento estatisticamente significante dos valores, da fase pré-expansão para a pós-expansão, nos três grupos estudados, ou seja, houve um aumento na largura maxilar, concordando com os achados de KORKHAUS $^{56}$ HAAS $^{42,43}$, KREBS ${ }^{57,58}$, CLEALL ${ }^{28}$, WERTZ ${ }^{111}$, HOFFER; WALTERS $^{51}$, BROGAN ${ }^{19}$, WERTZ; DRESKIN ${ }^{112}$, SATO; VIGORITO; CARVALHO $^{86}$, BISHARA; STALEY ${ }^{17}$, MEMIKOGLU; ISERI; UYSAL ${ }^{69}$, MAZZIEIRO $^{65}$, SPILLANE; MCNAMARA JÚNIOR ${ }^{101}$, CAPELOZZA FILHO; SILVA FILHO ${ }^{23}$ e MEMIKOGLU; ISERI ${ }^{68}$. Durante o período de contenção, nenhum dos três grupos apresentou alterações estatisticamente significantes, demonstrando a estabilidade na expansão, independente do tipo de ancoragem utilizada no aparelho expansor, apesar de uma pequena diminuição nos valores dos Grupos I e II e um discreto aumento no Grupo III. Esta estabilidade também foi observada por KREBS ${ }^{58}, \mathrm{CLEALL}^{28}, \mathrm{BROGAN}^{19}$, WERTZ; DRESKIN ${ }^{112}$, HAAS $^{46}$, MAZZIEIRO ${ }^{65}$, SPILLANE; MCNAMARA 
JÚNIOR $^{101}$ e MEMIKOGLU; ISERI ${ }^{68}$. Comparando-se as alterações entre o período pré-expansão e o período pós-contenção, os valores apresentaram-se estatisticamente significantes para os três grupos, corroborando os outros achados descritos anteriormente.

O gráfico 5.17 (p.151) demonstra as variações percentuais observadas para a medida JL-JR nos três grupos analisados, com o objetivo de facilitar a visualização da magnitude das alterações ocorridas. Como resultados imediatos da expansão (fase pré-expansão até a fase pós-expansão), o Grupo III apresentou um aumento percentual maior em relação aos outros dois grupos, ou seja, este teve um aumento de 4,3\%, enquanto o Grupo I e o Grupo II demonstraram respectivamente, $3,5 \%$ e 3,4\%. Durante o período de contenção, os grupos demonstraram respostas semelhantes, apesar de um pequeno decréscimo percentual nos Grupo I e II, porém sem significância estatística. Baseados nestas informações, conclui-se que o resultado final da $E R M$ sobre a largura maxilar foi ligeiramente maior no Grupo III, com aumento final de 4,4\%, sendo que para o Grupo I o aumento foi de 2,7 \% e para o Grupo II de 3,1\%. Este maior aumento percentual no Grupo III, pode ser explicado pelo menor valor desta medida ao início do tratamento.

Apesar destas pequenas variações descritas anteriormente, as Tabelas 5.13 a 5.15 (p.122 a 124) ilustram as comparações entre as alterações médias das variáveis analisadas nos três grupos e nos três períodos do estudo, ou seja, avaliam se existe alguma diferença entre as variações médias da variável JL-JR, entre as fases pré-expansão, pós-expansão e pós-contenção. Estas tabelas demonstram a ausência de diferenças estatisticamente significantes para a variável JL-JR entre os três grupos, portanto, independente do tipo de ancoragem utilizada, os efeitos sobre a maxila foram semelhantes. 


\section{4) Comportamento dos Molares de Ancoragem}

Parece indiscutível o envolvimento dentoalveolar durante o procedimento de ERM. Mesmo com a predominância das alterações ortopédicas, os efeitos ortodônticos, provocados pela liberação das forças de expansão e conseqüente compressão do ligamento periodontal, representados pela inclinação lateral dos processos alveolares e subseqüente vestibularização dos dentes de ancoragem, são evidentes. Estas respostas dentoalveolares, apresentam-se em maior magnitude, em detrimento dos efeitos ortopédicos, nos indivíduos com mais idade e conseqüentemente, maior resistência óssea ${ }^{26,58,63,96,111,112}$. KREBS ${ }^{57,58}$ demonstrou um maior aumento na largura do arco dentário superior, (distância intermolares) em comparação ao aumento da base maxilar, principalmente após a puberdade.

A movimentação dos primeiros molares superiores, em decorrência da $E R M$, foi avaliada com auxílio de seis medidas cefalométricas, sendo quatro lineares (RSR,CSC, A6-JL e 6A-JR) e duas angulares (6L.Z e 6R.Z).

As variáveis RSR e CSC avaliam o posicionamento transversal dos molares superiores, respectivamente, ao nível radicular e coronário. O comportamento destas variáveis durante os períodos estudados, adquire fundamental importância, pois demonstra o tipo de movimentação dentária ocorrida, ou seja, se houve maior movimento de inclinação ou de corpo. Os valores médios para os três grupos, ao início do tratamento, após a expansão e após o período de contenção, podem ser observados nas Tabelas 5.1 a 5.3 (p.110 a 112) e nos Gráficos 5.3, 5.4 (p.143), 6.3 e 6.4. 


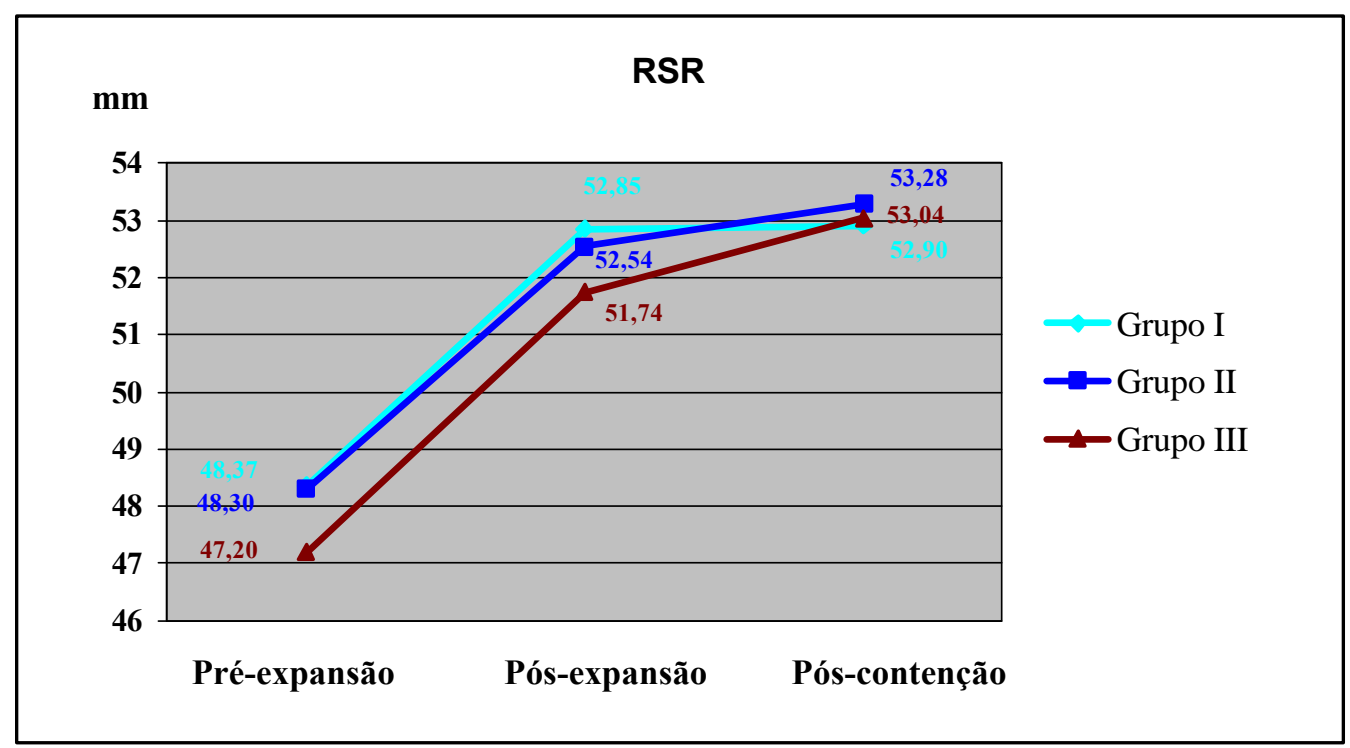

GRÁFICO 6.3 - Valores médios observados para a variável RSR

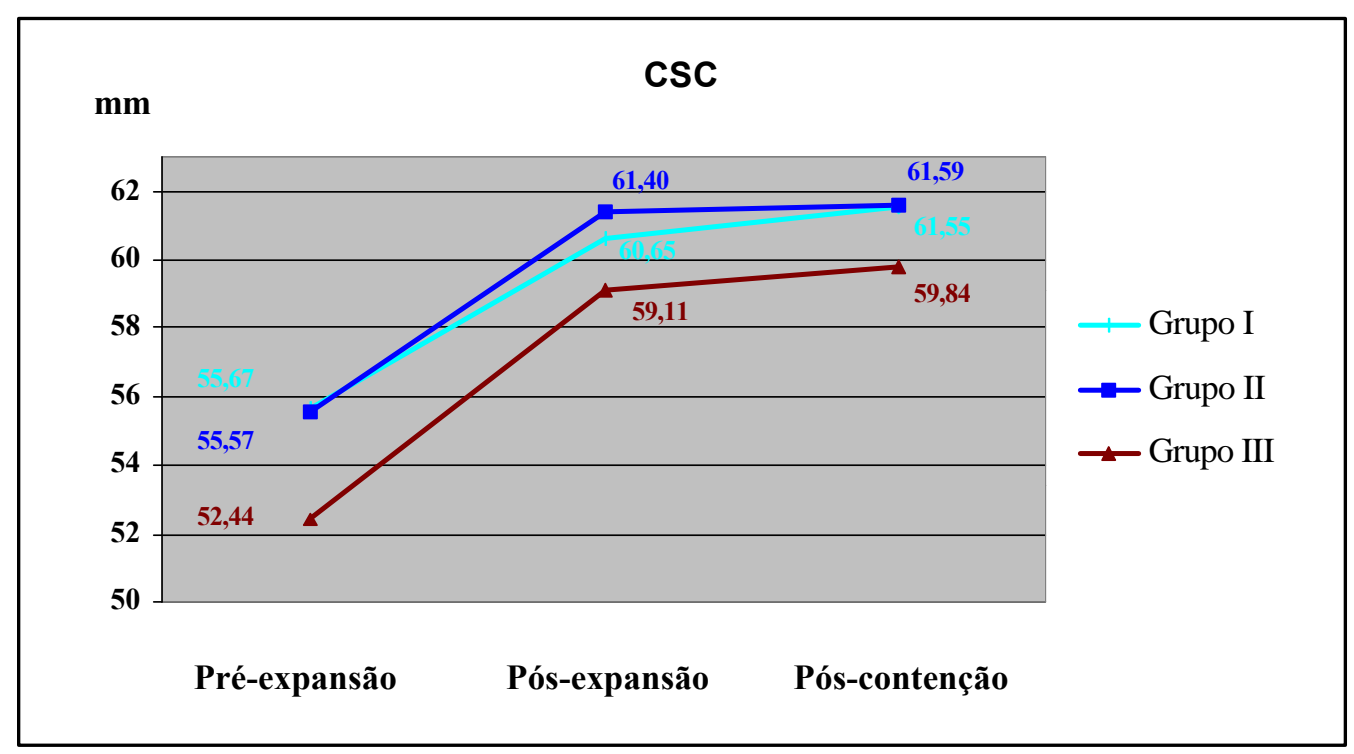

GRÁFICO 6.4 - Valores médios observados para a variável CSC 
Na tentativa de facilitar o entendimento, os resultados encontrados para as variáveis RSR e CSC nas Tabelas 5.4 a 5.12 (p.113 a 121), serão analisados separadamente, devido às diferenças observadas entre os três grupos.

A medida linear RSR apresentou alterações estatisticamente significantes imediatamente após a expansão nos três grupos estudados, demonstrando uma movimentação para vestibular da porção radicular dos molares de ancoragem. Durante a fase de contenção, os três grupos apresentaram aumentos nestes valores, porém, apenas o Grupo III demonstrou significância estatística, devido, principalmente, à atuação das forças residuais ${ }^{12,114}$. Na observação final, ou seja, a diferença entre os valores iniciais e os valores após a contenção, todos os grupos apresentaram alterações estatisticamente significantes.

O Gráfico 5.18 (p.151) ilustra as alterações percentuais desta variável, demonstrando valores semelhantes entre os três grupos, imediatamente após a expansão, com aumentos de 9,2 \% no Grupo I, 8,7 \% no Grupo II e 9,6 \% no Grupo III. Como citado anteriormente, o Grupo III foi o único que apresentou alterações estatisticamente significantes durante o período de contenção, sendo também ilustradas pelos valores percentuais. $\mathrm{Na}$ observação da magnitude de expansão, obtida ao final do tratamento, o Grupo III apresentou maior valor percentual, explicado pelo valor inicial inferior e pelo maior aumento durante a contenção, em comparação com os outros dois grupos.

As Tabelas 5.13 a 5.15 (p.122 a 124) ilustram as comparações entre os incrementos médios das variáveis analisadas nos três grupos, entre as fases préexpansão, pós-expansão e pós-contenção, demonstrando uma ausência de diferenças estatisticamente significantes para a variável RSR entre os três grupos. 
A variável CSC apresentou alterações estatisticamente significantes, imediatamente após a expansão, nos três grupos estudados, demonstrando uma movimentação para vestibular da porção coronal dos molares de ancoragem, ou seja, um aumento na distância intermolares superiores, concordando com KREBS $^{57,58}$, HAAS ${ }^{42,45}$, ZIMRING; ISAACSON ${ }^{114}$, STARNBACH et al ${ }^{104}$, DAVIS; KRONMAN ${ }^{32}$, MURRAY, CLEALL ${ }^{76}$, CAVASSAN $^{25}$, MEMIKOGLU; ISERI; UYSAL ${ }^{69}$, entre outros ${ }^{1,13,50,61,79,101,112}$. Durante a fase de contenção, os três grupos apresentaram aumentos nestes valores, porém, sem significância estatística, como observado por WERTZ; DRESKIN ${ }^{112}$. Na observação final, ou seja, a diferença entre os valores iniciais e os valores após a contenção, todos os grupos apresentaram alterações estatisticamente significantes.

O Gráfico 5.19 (p.152) ilustra as variações percentuais desta variável, demonstrando valores semelhantes para o Grupo I e para o Grupo II, porém um pouco discrepantes em comparação com o Grupo III, principalmente devido às diferenças entre os valores iniciais. Apesar destas diferenças percentuais, o gráfico mostra uma resposta semelhante, ou seja, uma movimentação vestibular dos molares de ancoragem após a ERM, com um pequeno movimento resultante durante o período de contenção.

As Tabelas 5.13 a 5.15 (p.122 a 124) ilustram as comparações entre os incrementos médios das variáveis analisadas nos três grupos e nos três períodos do estudo, ou seja, avaliam se existe alguma diferença entre os aumentos médios da variável CSC, entre as fases pré-expansão, pós-expansão e pós-contenção. $\mathrm{Na}$ avaliação desta medida, a análise de variância indicou uma discrepância entre os grupos durante a comparação dos resultados finais obtidos com a expansão, ou seja, na diferença dos valores pós-contenção e pré-expansão. A Tabela 5.16 (p.125) indica que esta discrepância foi observada entre o Grupo I 
(Haas), que apresentou um aumento médio de 5,87 $\mathrm{mm}$ e o Grupo III (expansor colado), com um aumento médio de $7,40 \mathrm{~mm}$, em consequiência da maior magnitude de expansão obtida neste grupo, sendo evidenciada pelos valores percentuais, onde o Grupo I demonstrou um aumento de $10,5 \%$ e o Grupo III de 14,1\%. Como citado anteriormente, esta diferença foi acusada devido aos valores iniciais menores no Grupo III (Tabela 5.31, p.141), necessitando assim uma maior expansão do arco superior, para a obtenção de uma oclusão satisfatória. Como os resultados foram muito semelhantes, conclui-se, portanto, que o tipo de ancoragem utilizada pelo aparelho expansor não influenciou na quantidade de aumento da distância intermolares superiores e na movimentação destes dentes de ancoragem, corroborando as afirmações de HERSHEY; STEWART; WARREN ${ }^{50}$, MEMIKOGLU; ISERI; UYSAL ${ }^{69}$ e ASANZA; CISNEROS; NIEBERG'.

Concordando com STARNBACH; CLEALL ${ }^{103}$, MURRAY; CLEALL ${ }^{76}$, HOFFER; WALTERS ${ }^{51}$, SPILLANE, MCNAMARA JÚNIOR ${ }^{101}$, os molares de ancoragem , quando analisados por estas duas variáveis, apresentaram uma inclinação vestibular associada a uma movimentação de corpo.

As outras duas medidas lineares, A6-JL e 6A-JR, utilizadas na avaliação dos primeiros molares superiores, indicam a distância entre a projeção do ponto A6 ou 6A ao plano oclusal, ao plano dentário frontal correspondente (JL-AG e JR-GA).

As Tabelas 5.1 a 5.3 (p. 110) e os Gráficos 5.6 (p.144), 5.7 (p.145), 6.5 e 6.6. demonstram os valores para os três grupos, ao início do tratamento, após a expansão e após o período de contenção das duas variáveis. A norma clínica preconizada por GUGINO $^{41}$ é de $6,3 \mathrm{~mm}$ e os valores acima deste, indicam a 
necessidade de expansão do arco superior com uma conseqüente diminuição neste valor.

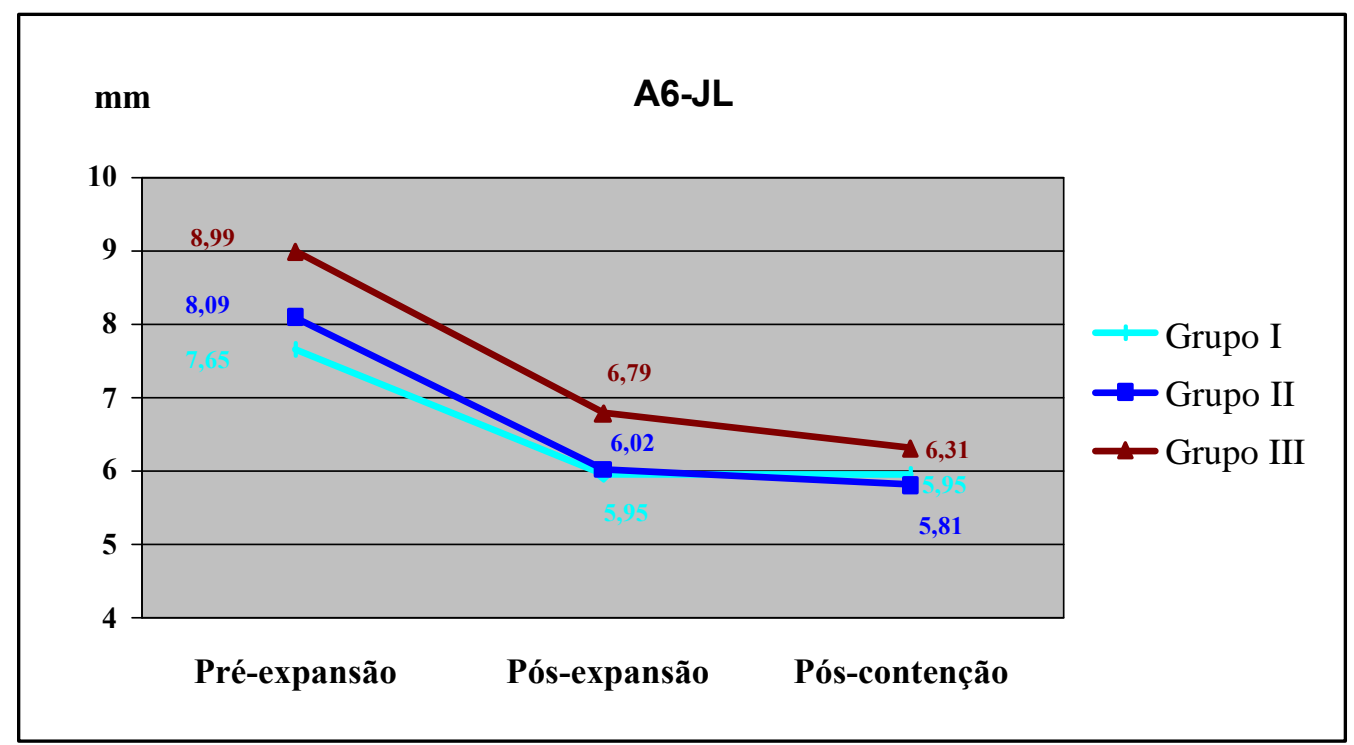

GRÁFICO 6.5 - Valores médios observados para a variável A6-JL.

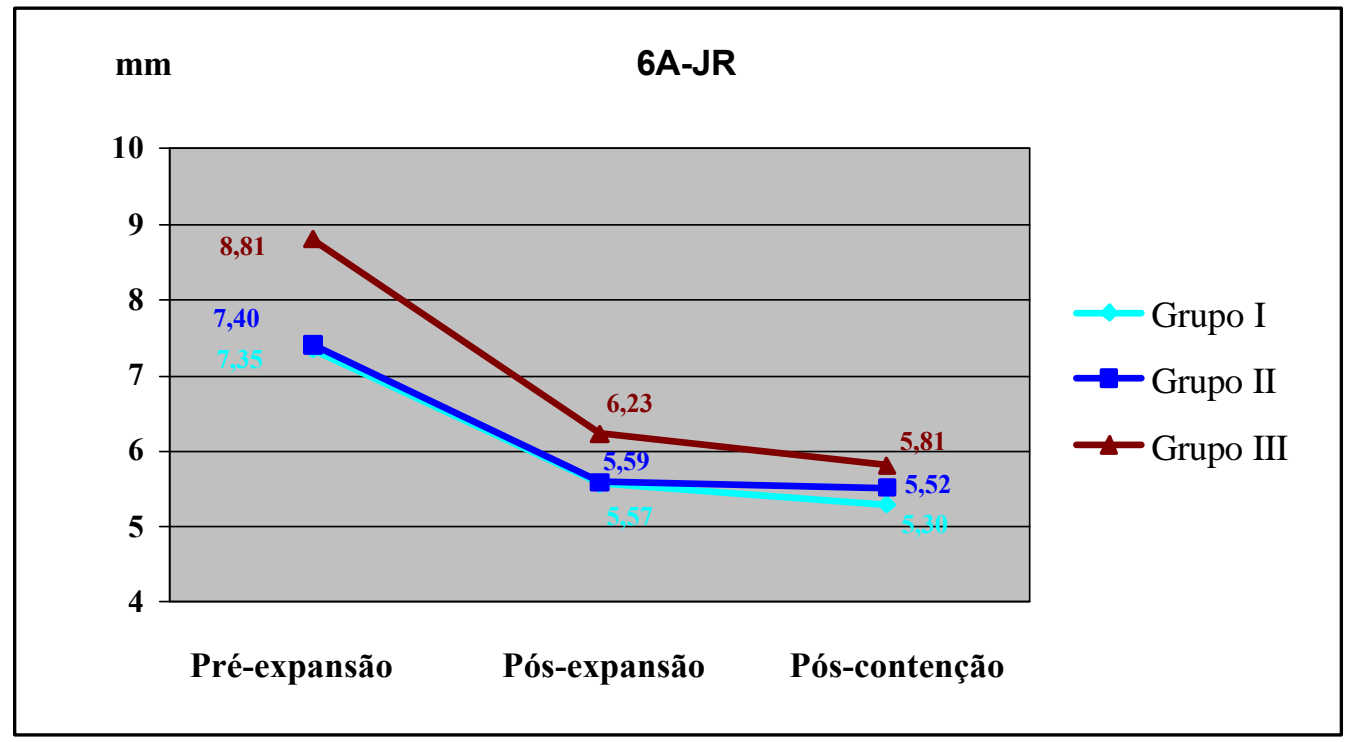

GRÁFICO 6.6 - Valores médios observados para a variável 6A-JR. 
Com o auxílio da análise estatística, ilustrada na Tabela 5.4 a 5.12 (p.113 a 121), observou-se uma diminuição estatisticamente significante nos valores após a expansão, indicando uma vestibularização destes dentes, em decorrência das alterações esqueléticas e dentoalveolares, concordando com literatura pertinente ${ }^{1,9,42,50,57,69,90}$.Durante o período de contenção, apesar de existir uma pequena diminuição nos valores, devido à ação das forças residuais, estas não foram estatisticamente significantes, portanto pode-se concluir que estas mantiveram-se estáveis neste período de três meses. E, corroborando as afirmações anteriores, a comparação entre as medidas iniciais e as finais, foram estatisticamente significantes para todos os grupos. Os valores iniciais dos três grupos, apresentavam-se maiores do que a norma preconizada por GUGINO ${ }^{41}$, demonstrando a necessidade de expansão do arco superior. Ao final da terapia, todos os valores (lado direito e esquerdo) mostraram-se dentro dos parâmetros de normalidade, inclusive menores do que o valor de GUGINO ${ }^{41}$. Isto demonstra e confirma a sobrecorreção que deve ser realizada no segmento póstero-superior, como preconizado por $\mathrm{HAAS}^{45}$, MOSS ${ }^{71}$, SILVA FILHO; CAPELOZZA FILHO $^{90}$, SANTOS PINTO; HENRIQUES ${ }^{82}$, em decorrência da pouca estabilidade das alterações dentoalveolares e a inevitável recidiva observada por KREBS $^{58}$, ZIMRING; ISAACSON ${ }^{114}$, LINDER-ARONSON; LINDGREN ${ }^{61}$, SANTOS PINTO; HENRIQUES ${ }^{82}$, CAVASSAN ${ }^{25}$ e ASANZA; CISNEROS; NIEBERG ${ }^{9}$.

Com relação as alterações percentuais, visualizadas nos gráficos $5.21 \mathrm{e}$ 5.22 (p.153), notou-se uma constância nas alterações ocorridas nos três grupos analisados. Apenas na comparação entre o aumento final conseguido, o Grupo III demonstrou valores percentuais maiores nas duas variáveis, devido à maior constrição do arco superior e maior inclinação lingual dos molares superiores ao 
início do tratamento, necessitando de uma maior expansão do arco superior para a obtenção de valores próximos dos ideais e de uma oclusão satisfatória.

As Tabelas 5.13 a 5.15 (p.122 a 124) ilustram as comparações entre os incrementos médios das variáveis analisadas nos três grupos e nos três períodos do estudo, ou seja, avaliam se existe alguma diferença entre as alterações médias das variáveis, entre as fases pré-expansão, pós-expansão e pós-contenção. Estas tabelas demonstram a ausência de diferenças estatisticamente significantes para a variável A6-JL entre os três grupos. Na avaliação da variável 6A-JR, a análise estatística indicou uma diferença entre os grupos durante a comparação dos resultados finais obtidos com a expansão, ou seja, a diferença dos valores póscontenção e pré-expansão. A Tabela 5.20 (p.129) indica que esta diferença foi observada entre o Grupo II (Hyrax) e o Grupo III (expansor colado), explicada pela maior magnitude de expansão obtida neste grupo (valor médio para o Grupo II foi de $-1,88 \mathrm{~mm}$ e de $-3,00 \mathrm{~mm}$ para o Grupo III), sendo também evidenciada pelos valores percentuais, onde o Grupo II demonstrou uma diminuição de $-25,4 \%$ e o Grupo III de $-34,1 \%$. Apesar destas diferenças, os três tipos de aparelhos apresentaram respostas semelhantes, podendo-se concluir que o a ancoragem utilizada pelo aparelho expansor não influenciou no tipo de movimentação dos molares de ancoragem.

As medidas angulares 6R.Z e 6L.Z, determinam as variações nas inclinações dos primeiros molares superiores. Como comentado na discussão do erro do método, a definição precisa do longo eixo dos molares superiores é praticamente impossível devido à grande sobreposição de imagens radiográficas. ADKINS; NANDA ; CURRIER ${ }^{1}$ relataram a inclinação vestibular dos molares de ancoragem, como parte do procedimento de expansão, porém esta é muito variável entre os pacientes, não demonstrando relação com a idade, a largura inicial do palato e a quantidade de expansão. 
As Tabelas 5.1 a 5.3 (p.110 a 112) e os Gráficos 5.8 (p.145), 5.9 (p.146), 6.7 e 6.8. demonstram os valores para os três grupos, ao início do tratamento, após a expansão e após o período de contenção das duas variáveis.

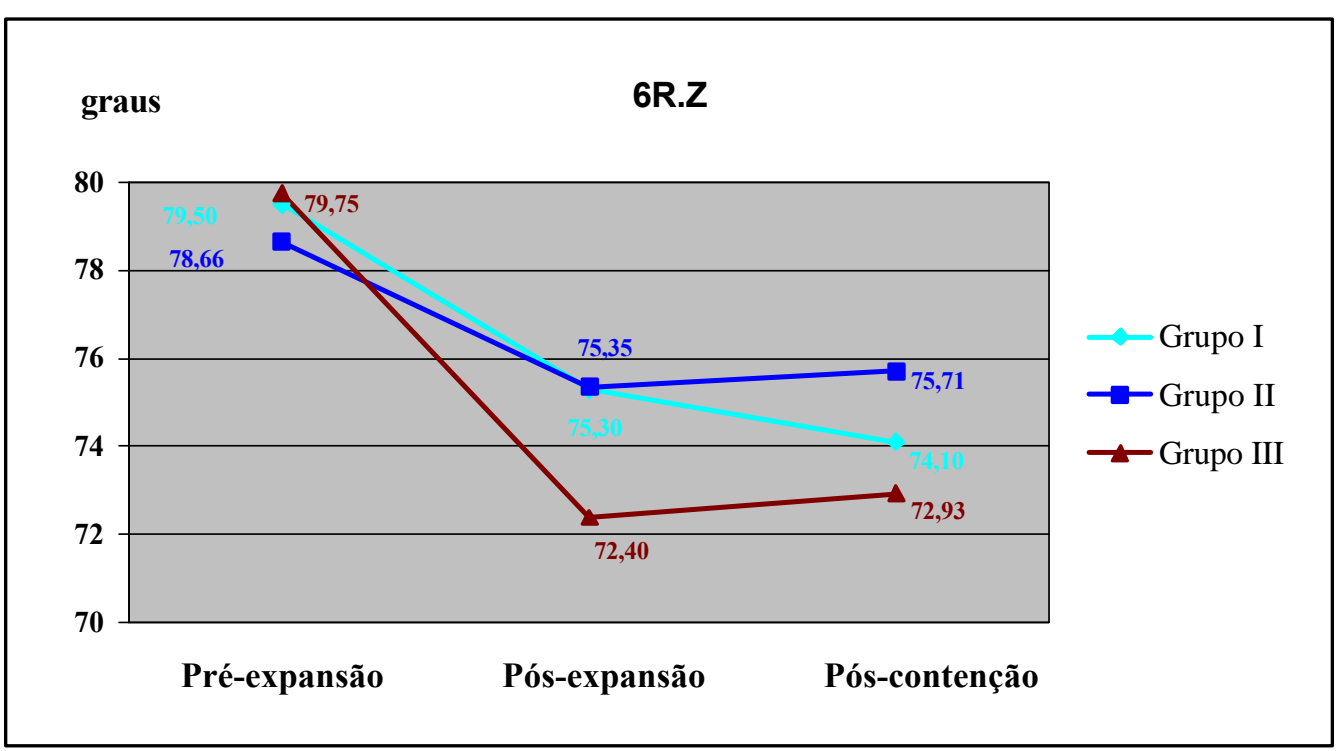

GRÁFICO 6.7 - Valores médios observados para a variável 6R.Z.

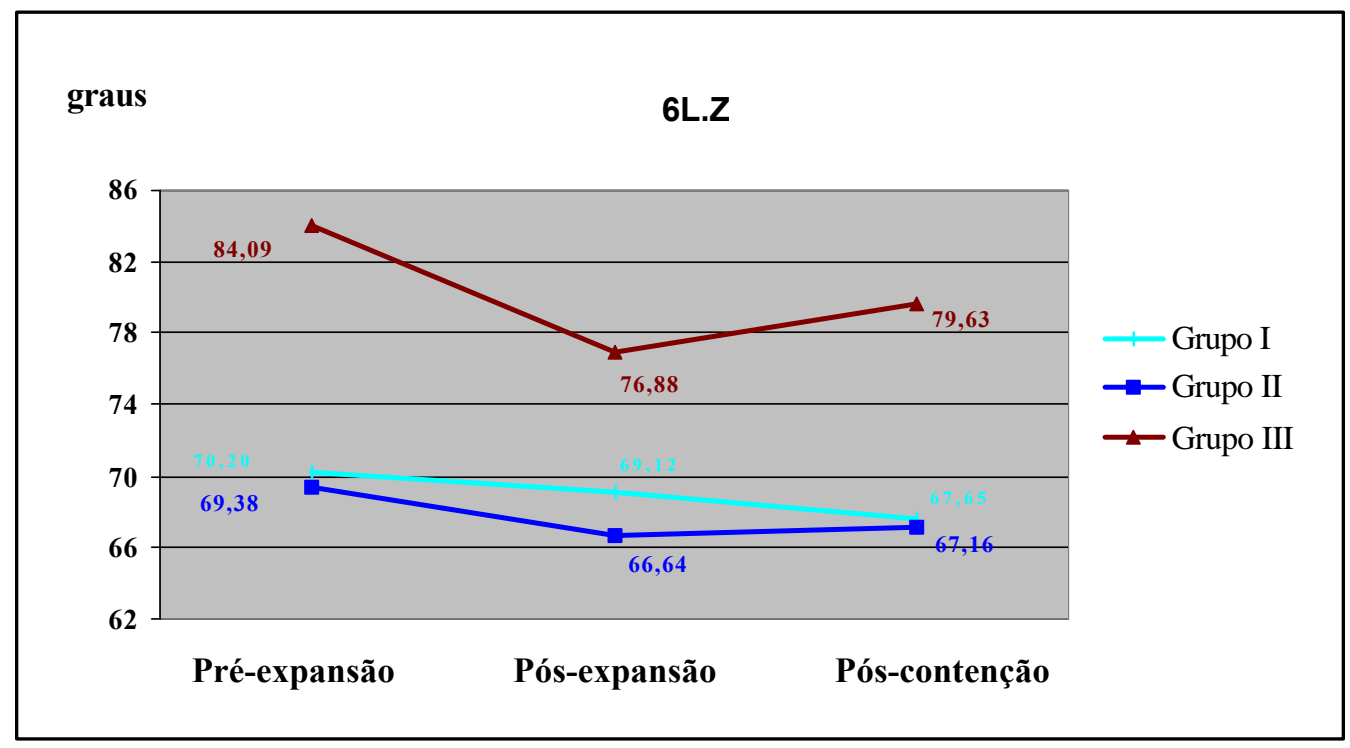

GRÁFICO 6.8 - Valores médios observados para a variável 6L.Z. 
As variáveis 6R.Z e 6L.Z serão discutidas separadamente, devido às diferenças observadas entre elas. No lado direito, ou seja, na avaliação da medida 6R.Z, foram observadas alterações estatisticamente significantes para o Grupo I e para o Grupo III, imediatamente após a expansão. O Grupo II, apesar de não apresentar valores significantes para a análise estatística, demonstrou uma resposta semelhante, ou seja, a diminuição do valor angular, indicando uma vestibularização dos primeiros molares superiores. Durante a contenção, os Grupo II e III demostraram uma tendência de verticalização, sem atingir os valores iniciais e o Grupo I apresentou uma suave inclinação vestibular durante este período, porém sem significância estatística. Os resultados das comparações dos valores finais com os iniciais confirmam e são idênticos aos comentados anteriormente.

$\mathrm{Na}$ visualização do Gráfico 5.23 (p.154), que ilustra as alterações percentuais da variável 6R.Z, conclui-se que o Grupo III apresentou uma maior inclinação vestibular dos dentes de ancoragem, sendo visualizada também no Gráfico 5.8 e nos valores percentuais, que foram de $-5,2 \%$ para o Grupo I, -4,2 \% para o Grupo II e de $-9,2$ \% para o Grupo III. Apesar destas discrepâncias relatadas, a análise de variância, ilustrada nas Tabelas 5.13 a 5.15 (p.122 a 124), demonstrou ausência de alterações estatisticamente significantes para esta variável.

A medida 6L.Z, apresentou resultados semelhantes à variável anteriormente analisada, ou seja, uma diminuição do valor angular imediatamente após a expansão, indicando uma vestibularização dos primeiros molares superiores. O Grupo III foi o único que apresentou alterações estatisticamente significantes nesta fase, observadas nas Tabelas 5.4 a 5.12 (p.113 a 121). Durante a contenção, os Grupo II e III demostraram uma 
tendência de verticalização, sem atingir os valores iniciais, e o Grupo I apresentou uma suave inclinação vestibular durante este período, com significância estatística apenas para o Grupo III. Os resultados das comparações dos valores finais com os iniciais confirmam os comentários anteriores.

$\mathrm{Na}$ visualização do Gráfico 5.24 (p.154), que ilustra as alterações percentuais da variável 6L.Z, conclui-se que o Grupo III apresentou uma maior inclinação vestibular dos dentes de ancoragem após a expansão, sendo também observada nos Gráficos 5.9 (p.146) e 6.8 e nos valores percentuais, que foram de $-1,5 \%$ para o Grupo I, $-3,9 \%$ para o Grupo II e de $-8,5 \%$ para o Grupo III. Durante os três meses de contenção, houve uma maior tendência de verticalização dos molares no Grupo III, como para a variável 6R.Z.

A análise estatística (ANOVA), ilustrada nas Tabelas 5.13 a 5.15 (p.122 a 124), confirmou as diferenças relatadas anteriormente. Imediatamente após a expansão, houve diferenças estatisticamente significantes entre o Grupo I (Haas) e o Grupo III (Colado) e entre o Grupo II (Hyrax) e o Grupo III (Colado), que podem ser observadas na Tabela 5.21 (p.130), devido à pouca inclinação vestibular dos molares de ancoragem observada para os dois primeiros grupos. Na Tabela 5.22 (p.131), observa-se a comparação entre os três grupos durante o período de contenção, notando-se diferenças estatisticamente significantes entre o Grupo I (Haas) e o Grupo III (Colado), devido à maior tendência de verticalização deste último grupo. Apesar destas diferenças relatadas, ao se comparar as alterações resultantes (pré-expansão até pós-contenção), a análise estatística não acusou diferenças estatisticamente significantes.

Baseados na análise destas duas variáveis angulares, conclui-se que apesar de uma maior tendência de vestibularização dos molares de ancoragem com o aparelho colado (Grupo III), após a fase ativa de expansão, e maior grau de verticalização durante a contenção, os três aparelhos apresentaram respostas 
semelhantes, sem diferenças estatísticas ao final do período de contenção, não havendo diferenças na magnitude das inclinações vestibulares dos dentes de ancoragem, concordando com ASANZA; CISNEROS; NIEBERG ${ }^{9}$ e discordando de MOSS $^{72}$, MEMIKOGLU; ISERI; YUSAL ${ }^{69}$ e de MEMIKOGLU; ISERI $^{68}$, que afirmaram que o expansor colado causaria menores inclinações vestibulares dos dentes de ancoragem. 


\section{5) Comportamento dos Primeiros Molares Inferiores}

A variação transversal dos $1^{\text {os }}$ molares inferiores, ou seja, as alterações na distância entre estes dentes foi analisada com a medida linear CIC, apesar de não ser uma área de atuação direta do procedimento de expansão rápida da maxila.

Os valores médios pré-expansão, pós-expansão e pós-contenção dos três grupos, estão dispostos nas Tabelas 5.1 a 5.3. e ilustrados nos Gráficos 5.5 (p.144) e 6.9. Nos Grupos I e II observou-se um aumento da distância intermolares inferiores ao final do período de observação, corroborando os achados de HAAS ${ }^{42,46}$, DAVIS; KRONMAN ${ }^{32}$, HOFFER; WALTERS ${ }^{51}$, WERTZ; DRESKIN ${ }^{112}$, GRYSON ${ }^{40}$, SANDSTRON; KLAPER; PAPACONSTANTINOU ${ }^{81}$, ADKINS; NANDA; CURRIER $^{1}$ e AKKAYA; LORENZON; ÜÇEN ${ }^{2}$. Estas mudanças são atribuídas às alterações nas forças resultantes de oclusão e a obtenção de um equilíbrio muscular (musculatura facial e da língua) após a ERM. GRYSON ${ }^{40}$ alertou, que mesmo com a obtenção de pequenos aumentos nas distâncias intercaninos e intermolares inferiores, não se justifica o procedimento de $E R M$ para esta finalidade.

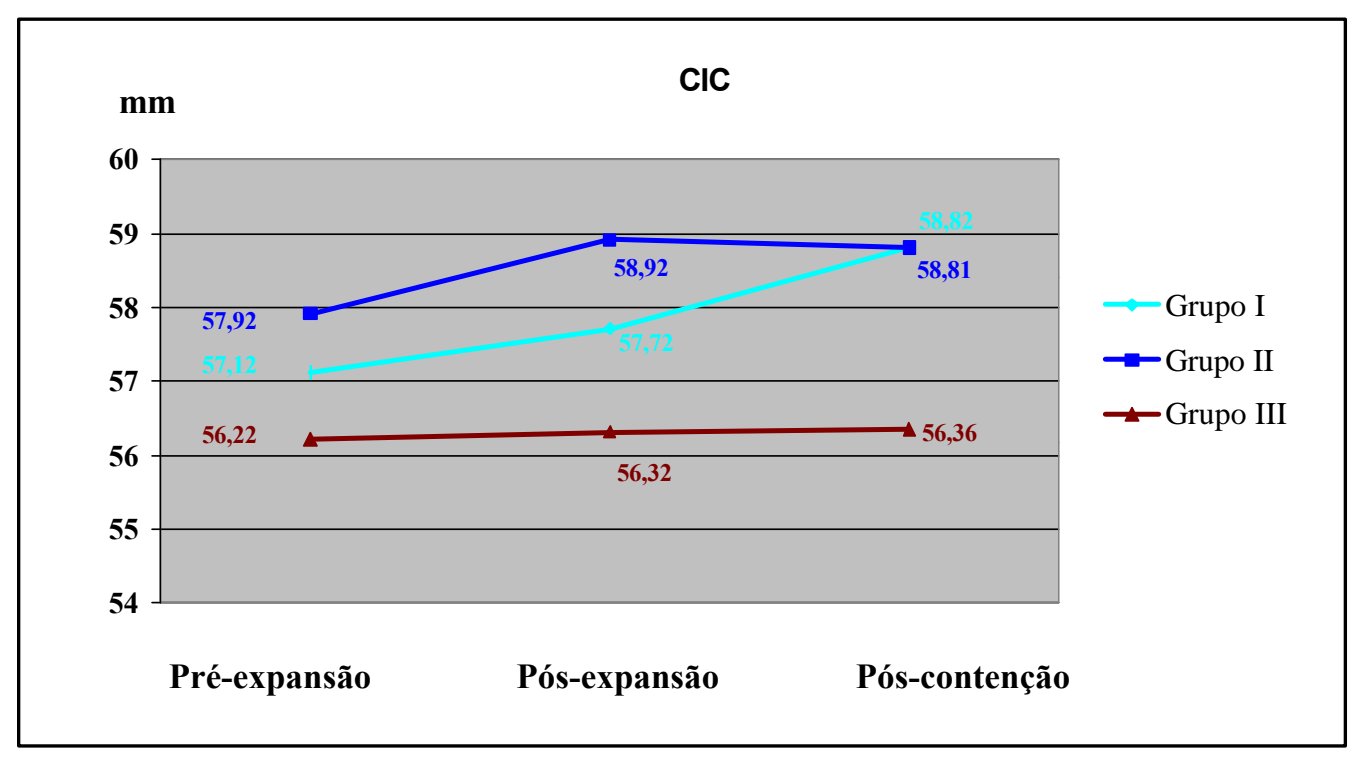

GRÁFICO 6.9 - Valores médios observados para a variável CIC. 
O Grupo III apresentou apenas pequenos aumentos na distância intermolares inferiores após o período de contenção. Esta pequena alteração, em comparação aos outros grupos, pode ter sido influenciada pelas forças intrusivas oriundas da porção de acrílico na região póstero-superior do aparelho, atuando como um BiteBlock, como citado por SARVER; JOHNSTON ${ }^{83}$, impedindo a verticalização destes dentes.

Os resultados encontrados para a distância CIC, ilustrados nas tabelas 5.4 a 5.12 (p.113 a 121), indicam que para o Grupo I (Haas), houve um aumento estatisticamente significante dos valores, da fase pré-expansão para a póscontenção. No Grupo II (Hyrax), o aumento observado imediatamente após a expansão e ao final da observação, apresentaram-se estatisticamente significantes. As alterações durante a fase de contenção não demonstraram significância estatística. No Grupo III (Colado), não se observaram alterações estatisticamente significantes em nenhuma das comparações realizadas.

O Gráfico 5.20 (p.152) demonstra as variações percentuais observadas para a medida CIC nos três grupos analisados, com o objetivo de facilitar a visualização da magnitude das alterações ocorridas. Estes valores confirmam o que foi comentado anteriormente, ou seja, o Grupo I e o Grupo II apresentaram maiores aumentos nas distâncias intermolares inferiores, imediatamente após a expansão, com valores percentuais de $1,0 \%$ e 1,7 \%, respectivamente, enquanto o Grupo III apresentou um valor percentual de 0,1\%. Apenas no Grupo II, observou-se algum tipo de alteração durante o período de contenção, caracterizado por um aumento percentual de 1,9\%.

Com a aplicação da análise de variância, ilustrada nas Tabelas 5.13 a 5.15 (p.122 a 124), confirmaram-se as diferenças relatadas anteriormente. Imediatamente após a expansão, houve diferenças estatisticamente significantes entre o Grupo II (Hyrax) e o Grupo III (Colado), que podem ser observadas na 
Tabela 5.17 (p.126) e explicadas pelo maior aumento desta variável no grupo que utilizou o aparelho tipo Hyrax. Na Tabela 5.18 (p.127), observa-se a comparação entre os três grupos durante o período de contenção, notando-se diferenças estatisticamente significantes entre o Grupo I (Haas) e o Grupo II (Hyrax). Para complementar as comparações, a Tabela 5.19 (p.128) ilustra a diferença observada na avaliação dos valores médios finais, ou seja, aqueles obtidos pela subtração dos valores médios pós-contenção dos do pré-tratamento. A diferença foi acusada entre os grupos I (Haas) e III (Colado), devido ao maior aumento da distância intermolares inferiores observada no Grupo I, que apresentou um aumento médio de 1,70 mm e o Grupo III de 0,14 mm. O Grupo II demonstrou um aumento de $0,88 \mathrm{~mm}$ em média, o qual não demonstrou diferenças estatísticas com os outros dois grupos.

Após a observação destas características descritas anteriormente, parece lícito afirmar que apenas o expansor colado apresenta algum tipo de diferença na forma de atuação e na resposta dos dentes inferiores após a ERM. Portanto, existe uma possibilidade maior de haver modificações transversais do arco inferior em decorrência da $E R M$, principalmente com a utilização do expansor tipo Haas e tipo Hyrax. 


\section{6) Comportamento dos Incisivos Centrais Superiores}

A telerradiografia em norma frontal denota importância acadêmica na definição radiográfica da trajetória dos incisivos centrais superiores durante a fase ativa e passiva da expansão ${ }^{23}$. Para esta avaliação, foram utilizadas quatro variáveis, sendo duas lineares (AI-IA e IM-MI) e duas angulares (A1R.Z e A1L.Z).

Os valores médios para as medidas AI-IA e IM-MI, que demonstram o comportamento das distâncias entre os ápices e as faces mesiais das coroas dos incisivos centrais superiores, respectivamente, podem ser observadas nas Tabelas 5.1 a 5.3 (p.110 a 112) e nos Gráficos 5.10 (p.146), 5.11 (p.147), 6.10 e 6.11. Com a análise destes dados, conclui-se que as raízes dos incisivos se distanciam imediatamente após a expansão e durante o período de contenção demonstram uma certa estabilidade no posicionamento. Com relação às coroas, os valores aumentam consideravelmente após a expansão e durante o período de contenção estes retornam praticamente aos seus valores iniciais, devido à mesialização das coroas, corroborando os estudos de $\mathrm{HAAS}^{42,43}, \mathrm{MOSS}^{72}$, SILVA FILHO; PINHEIRO JÚNIOR; CAVASSAN ${ }^{95}$ e CAPELOZZA FILHO; SILVA FILHO ${ }^{23}$. Estes autores observaram que a abertura da sutura palatina mediana pode ser constatada clinicamente pelo aparecimento de um diastema entre os incisivos centrais superiores, caracterizado pela divergência apical e convergência das coroas, que se fecha após alguns meses, devido à maior aproximação das coroas, estimulada pela contração elástica das fibras transeptais, que foram estiradas durante a expansão. SILVA FILHO; MONTES; TORELLY ${ }^{94}$, em 1995, quantificaram as distâncias entre os ápices (média de 3,5 $\mathrm{mm}$ ) e as faces mesiais das coroas dos incisivos (média de 2,9 mm), com o auxilio de telerradiografias em norma frontal, obtidas nas fases pré-expansão e 
imediatamente pós-expansão, demonstrando, como neste estudo, valores maiores para a distância entre os ápices, caracterizando uma divergência apical e convergência das coroas, imediatamente após a expansão .

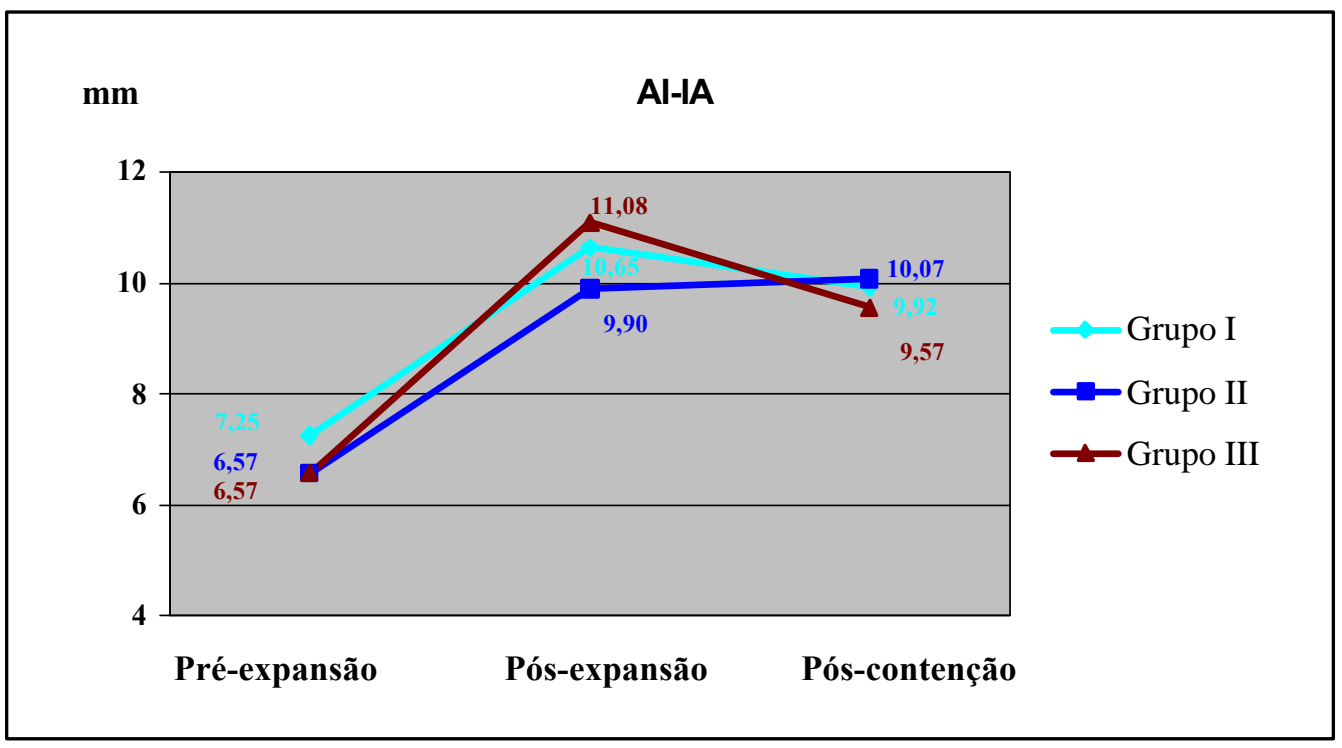

GRÁFICO 6.10 - Valores médios observados para a variável AI-IA.

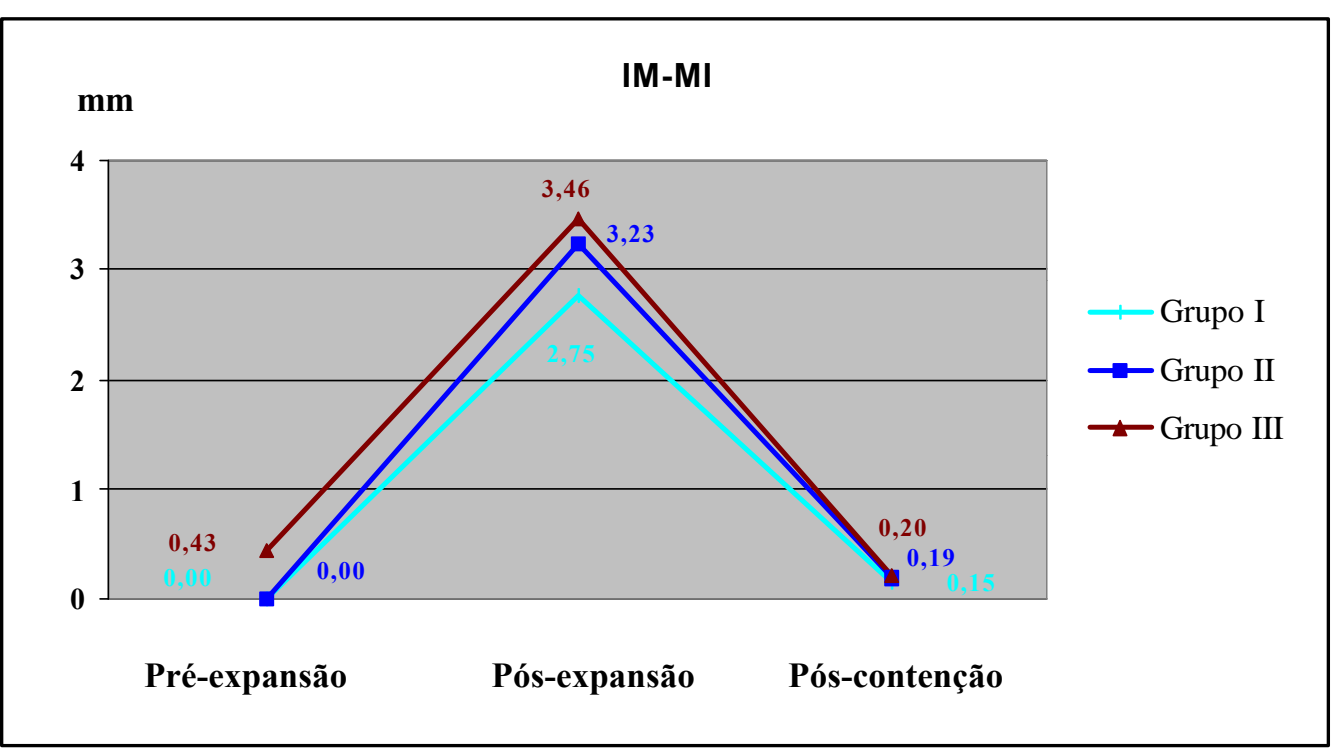

GRÁFICO 6.11 - Valores médios observados para a variável IM-MI. 
Para uma melhor compreensão, os resultados das análises estatísticas, que estão ilustrados nas Tabelas 5.4 a 5.12 (p.113 a 121), serão analisados separadamente. A variável AI-IA, apresentou alterações estatisticamente significantes imediatamente após a expansão, nos três grupos analisados, demonstrando um distanciamento entre os ápices radiculares. Durante o período de contenção, apenas o Grupo III demonstrou alterações estatisticamente significantes, devido à maior tendência de retorno à sua posição original, porém sem atingi-la. Na avaliação final, os valores resultantes após o período de contenção demonstraram-se estatisticamente significantes para os três grupos. Estas alterações também podem ser observadas no Gráfico 5.25 (p.155), que ilustra a magnitude das alterações percentuais para esta variável. Imediatamente após a expansão, o Grupo III demonstrou aumentos percentuais maiores, com valores de 46,8 \% para o Grupo I, 50,6 \% para o Grupo II e 68,8 \% para o Grupo III. Durante o período de contenção, os Grupo I e III apresentaram diminuições nos valores de, respectivamente, $-6,7 \%$ e $-13,6 \%$. O Grupo II manteve-se praticamente estável.

$\mathrm{Na}$ comparação dos incrementos médios para os três grupos, visualizados nas Tabelas 5.13 a 5.15 (p.122 a 124), nota-se uma diferença estatisticamente significante durante a fase de contenção. Com a aplicação do teste de Tukey, confirmou-se a diferença entre o Grupo II (Hyrax) e o Grupo III (Colado), devido à maior aproximação dos ápices radiculares no Grupo III e uma constância nos valores dos Grupos II. Apesar desta diferença, na comparação das respostas finais desta variável, notou-se uma ausência de diferenças estatisticamente significantes. 
A variável IM-MI, apresentou alterações estatisticamente significantes imediatamente após a expansão nos três grupos analisados, comprovando a abertura do diastema entre os incisivos centrais superiores em decorrência da ERM. ZIMRING; ISAACSON ${ }^{114}$ relataram o aparecimento deste diastema entre os incisivos centrais superiores entre a $9^{\mathrm{a}}$ e a $12^{\mathrm{a}}$ ativações. Durante o período de contenção, os valores apresentaram uma diminuição estatisticamente significante nos três grupos, devido à ação das fibras transeptais, que aproximam estes dentes após alguns meses de contenção, causando o fechamento do diastema e uma convergência das coroas. Na avaliação final, ou seja, na comparação dos valores médios pré-expansão e pós-contenção, nenhum dos grupos apresentou diferenças estatisticamente significantes, caracterizando mais uma vez, a tendência do fechamento do diastema durante os três meses de contenção.

Na comparação dos incrementos médios para os três grupos, visualizada nas Tabelas 5.13 a 5.15 (p.122 a 124), nota-se uma diferença estatisticamente significante na resposta final desta variável, ou seja, na comparação dos incrementos médios entre a fase inicial e a fase pós-contenção. Com a aplicação do teste de Tukey, ilustrado na tabela 5.24 (p.133), confirmou-se a diferença entre o Grupo II (Hyrax) e o Grupo III (Colado), devido à presença de um pequeno diastema no período pré-expansão no Grupo III. Apesar das pequenas diferenças observadas, não acreditamos que o tipo de aparelho ou a forma de ancoragem utilizada por este dispositivos possam afetar as respostas dos incisivos superiores. 
As outras duas variáveis utilizadas para a avaliação dos incisivos centrais superiores (A1R.Z e A1L.Z) quantificam as alterações angulares destes dentes em relação ao Plano Z. Os valores médios destas medidas, podem ser observados nas Tabelas 5.1 a 5.3 (p.110 a 112) e nos Gráficos 5.12 (p.147), 5.13 (p.148), 6.12 e 6.13. Com a análise destes dados, observa-se um aumento nos valores angulares imediatamente após a expansão e durante o período de contenção, denotando um movimento de inclinação destes dentes durante o seu distanciamento (fase ativa) e durante a sua aproximação (fase passiva), devido à ação das fibras transeptais que promovem uma movimentação mais rápida das coroas, em comparação ao movimento radicular, corroborando os estudos de HAAS $^{42,43}$, MOSS ${ }^{72}$, SILVA FILHO; PINHEIRO JÚNIOR; CAVASSAN ${ }^{95}$ e CAPELOZZA FILHO; SILVA FILHO ${ }^{23}$

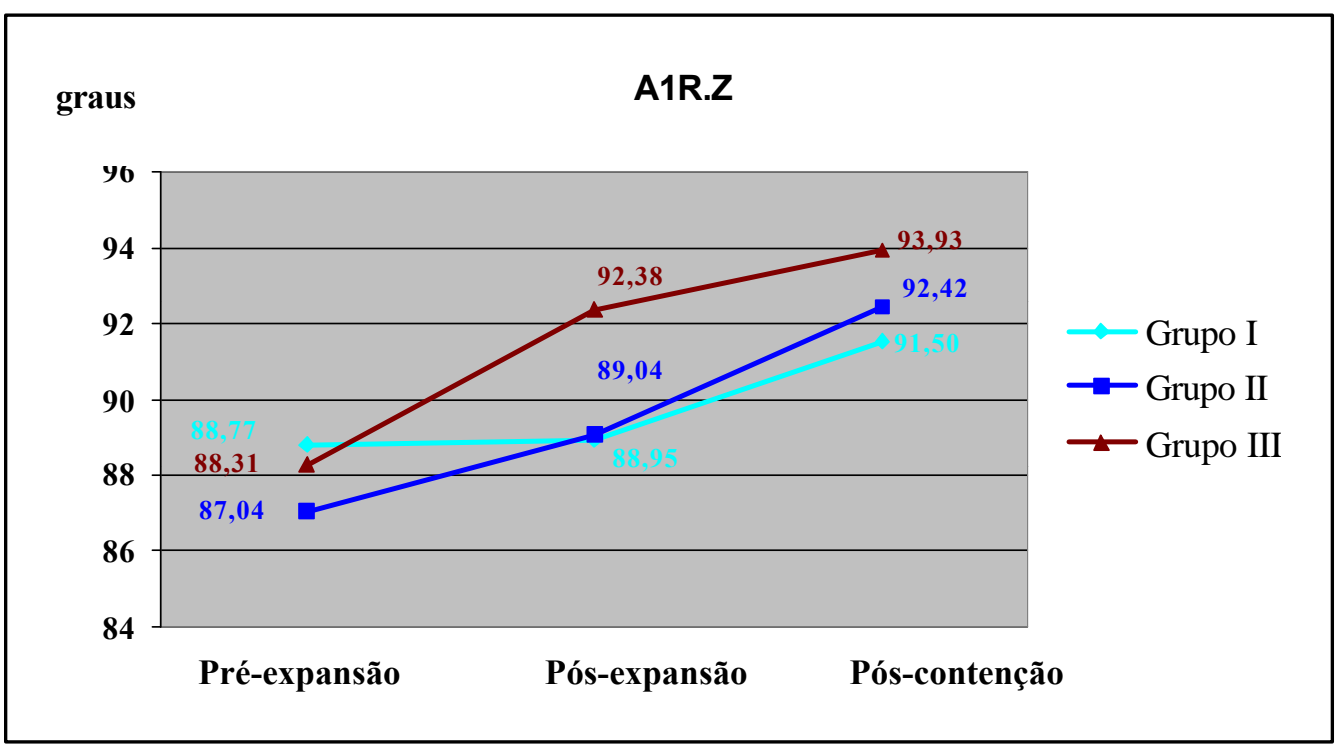

GRÁFICO 6.12 - Valores médios observados para a variável A1R.Z. 


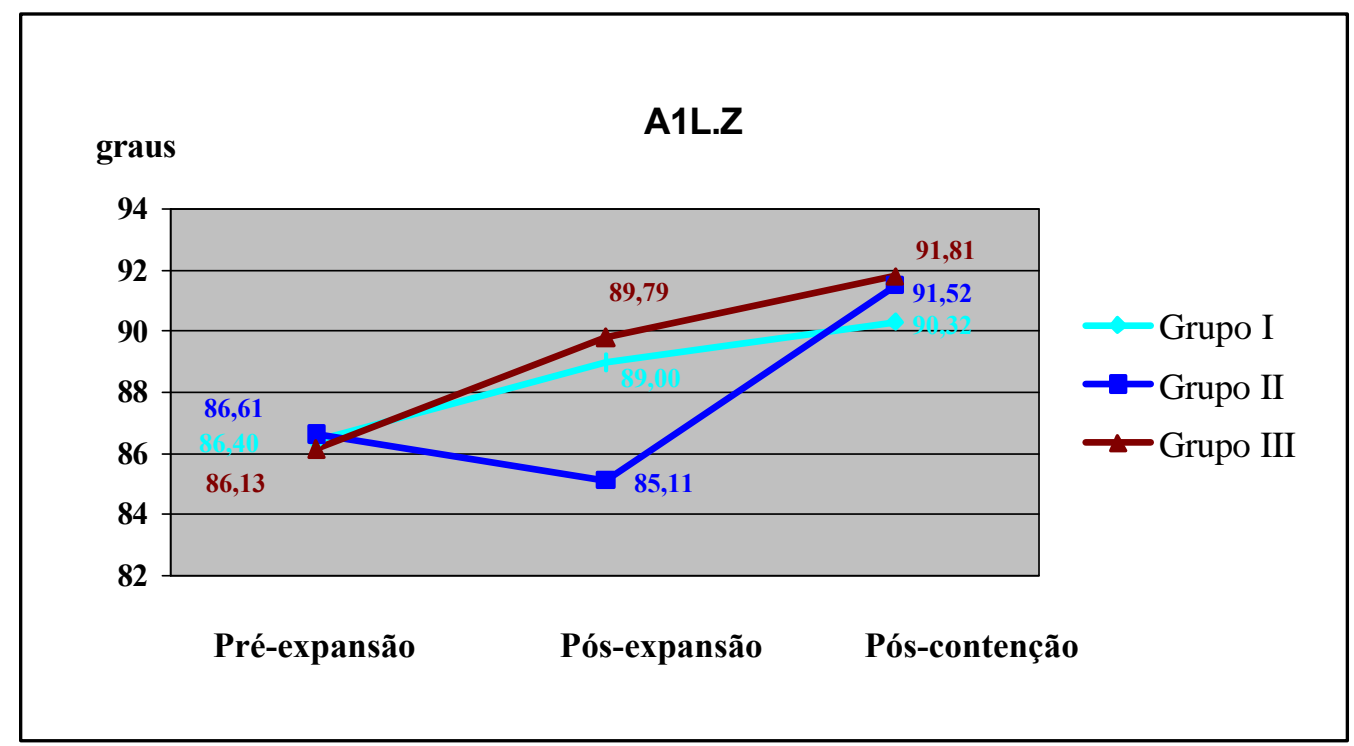

GRÁFICO 6.13 - Valores médios observados para a variável A1L.Z.

Apesar das diferenças observadas com a realização das análises estatísticas, ilustradas nas Tabelas 5.4 a 5.15 (p.113 a 124) e 5.25 a 5.27 (p.134 a 136) e com a análise das variações percentuais nos Gráficos 5.26 e 5.27 (p.156), conclui-se que estes dentes apresentaram um comportamento muito semelhante, com uma divergência apical e convergência das coroas durante o período de expansão e contenção, como observado nos estudos clássicos de $\operatorname{HAAS}^{42,43}$. Segundo SILVA FILHO; PINHEIRO JÚNIOR; CAVASSAN ${ }^{95}$, em um estudo radiográfico longitudinal, apesar de uma tendência de retorno à posição original, mesmo após 12 meses, a angulação interincisivos permaneceu diferente da original. Notou-se uma pequena diferença na medida A1L.Z, imediatamente após a expansão, porém como os aparelhos não atuam diretamente sobre os incisivos superiores, torna-se confiável afirmar que a movimentação destes dentes não foi influenciada diretamente pelo tipo de aparelho e sim devido aos efeitos indiretos provenientes da abertura da sutura palatina mediana. 


\section{7) Comportamento da Sobremordida e da AFAI}

A abertura da sutura palatina mediana, decorrente da $E R M$, provoca certas alterações na maxila e conseqüentemente nas estruturas contíguas. Alguns autores relatam um deslocamento maxilar para frente e para baixo ${ }^{42,43,111,112}$, porém outros estudos descrevem apenas um deslocamento inferior da maxila, sem qualquer alteração no sentido sagital ${ }^{21,22,23,55,97,99}$. Como efeito deste indiscutível deslocamento inferior da maxila, da extrusão e vestibularização dos molares de ancoragem e da inclinação dos processos alveolares, a mandíbula sofre uma rotação para baixo e para trás. Ao girar no sentido horário, a mandíbula induz alterações cefalométricas significativas, como o aumento da altura facial ântero-inferior, do eixo "y" de crescimento e do ângulo do plano mandibular, além de uma pequena tendência de abertura da mordida, sendo desfavoráveis para os pacientes com padrão de crescimento excessivamente vertical. Na tentativa de minimizar estes efeitos colaterais indesejáveis da expansão, muitos autores descreveram a utilização do expansor com cobertura de acrílico colado aos dentes superiores. Para a comparação e análise das alterações verticais observadas nos pacientes desta pesquisa, utilizou-se duas variáveis : 1) SOBREMORDIDA, que avalia o trespasse vertical dos incisivos; 2) AFAI, que avalia as alterações na altura facial ântero-inferior. No Grupo III esta variáveis não foram obtidas imediatamente após a expansão, devido à espessura variável do bloco de resina posterior, podendo interferir nos resultados finais.

Os valores médios pré-expansão, pós-expansão e pós-contenção, para a medida SOBREMORDIDA estão dispostos nas Tabelas 5.1 a 5.3 (p.110 a 112) e nos Gráficos 5.14 (p.148) e 6.14. 


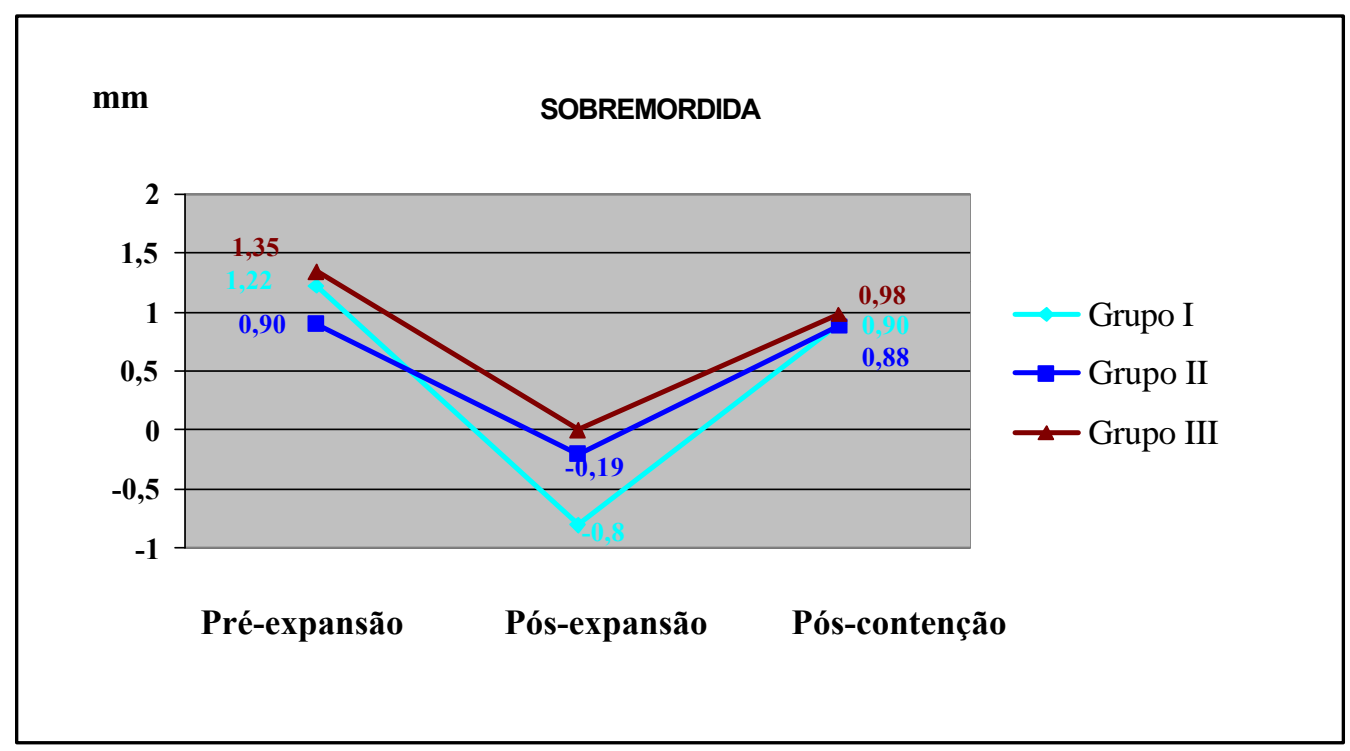

GRÁFICO 6.14 - Valores médios observados para a variável SOBREMORDIDA.

Com a análise das Tabelas 5.4 a 5.12 (p.113 a 121), observa-se que a medida linear SOBREMORDIDA, apresentou alterações estatisticamente significantes imediatamente após a expansão nos dois grupos estudados (Haas e Hyrax), demonstrando uma abertura da mordida na região anterior, devido ao novo posicionamento dos molares de ancoragem e a rotação da mandíbula no sentido horário, concordando com os estudos de HAAS ${ }^{43}$, DAVIS; KRONMAN $^{32}$, HEFLIN $^{49}$, WERTZ ${ }^{111}$, BYRUN JÚNIOR ${ }^{21}$, WHITE ${ }^{113}$, SILVA FILHO; VILAS BOAS; CAPELOZZA FILHO ${ }^{97}$. Durante a fase de contenção, as alterações também foram estatisticamente significantes para os dois grupos, com uma tendência de retorno aos valores iniciais, como descrito por WERTZ $^{111}$, LINDER-ARONSON; LINDGREN ${ }^{61}$, MAZZIEIRO $^{65}$ e KAWAKAMI $^{55}$. Na observação das alterações finais, ou seja, na comparação dos valores iniciais e os valores após os três meses de contenção, nenhum dos três grupos apresentou alterações estatisticamente significantes, o que demonstra 
mais uma vez, a tendência de retorno aos valores iniciais desta variável após o período de contenção, podendo ser explicado pela tendência de normalização no posicionamento das estruturas ósseas (mandíbula) e auxiliado pela extrusão e lingualização dos incisivos superiores durante este período ${ }^{3,9,111}$.

As Tabelas 5.13 e 5.15 (p.122 a 124), ilustram as comparações entre as diferenças médias nas três fases estudadas, concluindo-se que existiram diferenças estatisticamente significantes entre o Grupo I (Haas) e o Grupo II (Hyrax), uma vez que as alterações verticais imediatamente após a expansão foram maiores no Grupo I. Porém, nas comparações entre as variações durante a fase de contenção e a variação total, do início ao final do período de contenção, não se observaram diferenças significantes entre os três grupos, contrariando MEMIKOGLU, ISERI; UYSAL ${ }^{69}$, que observaram uma maior alteração na sobremordida no grupo que utilizou o expansor bandado.

Os valores médios pré-expansão, pós-expansão e pós-contenção, para a medida AFAI estão dispostos nas Tabelas 5.1 a 5.3 (p.110 a 112) e nos Gráficos 5.15 (p.149) e 6.15. Observou-se um aumento desta medida imediatamente após a expansão, como relatado por HAAS ${ }^{43}$, DAVIS; KRONMAN ${ }^{32}$, HEFLIN $^{49}$, WERTZ $^{111}$, BYRUN JÚNIOR ${ }^{21}$, LINDER-ARONSON; LINDGREN ${ }^{61}$, WHITE $^{113}$, SILVA FILHO; VILAS BOAS; CAPELOZZA FILHO ${ }^{97}$ e SILVA FILHO et al ${ }^{99}$ e uma diminuição durante o período de contenção, demonstrando uma tentativa de retorno aos valores iniciais, porém sem alcançá-los. Segundo WERTZ $^{111}$, LINDER-ARONSON; LINDGREN ${ }^{61}$ e KAWAKAMI ${ }^{55}$, a mandíbula que foi deslocada para baixo e para trás em decorrência da $E R M$, causando este aumento na AFAI e conseqüente aumento nos ângulos NAP e ANB, demostrou uma tendência de retorno à sua posição original durante $o$ período de contenção. 


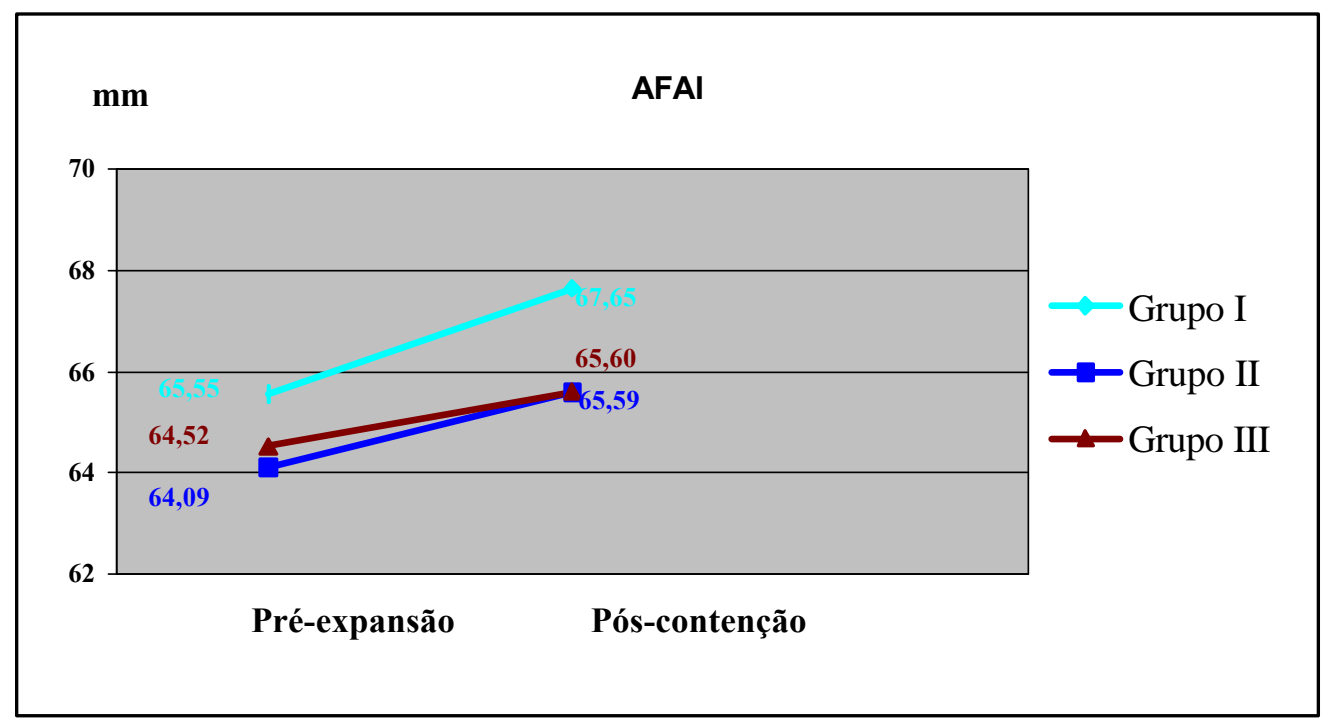

GRÁFICO 6.15 - Valores médios observados para a variável AFAI.

A medida linear AFAI, obtida pela distância em milímetros dos pontos ENA e ME, apresentou alterações estatisticamente significantes imediatamente após a expansão nos dois grupos estudados (Haas e Hyrax), devido à fatores comentados anteriormente, como o novo posicionamento dos molares de ancoragem, a sobrecorreção do segmento póstero-superior, o deslocamento inferior da maxila e a rotação da mandíbula no sentido horário. Durante a fase de contenção, as alterações não foram estatisticamente significantes para os dois grupos, apesar de apresentarem uma tendência de retorno aos valores iniciais. Nas observações finais, ou seja, na comparação dos valores iniciais e dos valores obtidos após os três meses de contenção, o Grupo I (Haas) e o Grupo II (Hyrax) demonstraram alterações estatisticamente significantes, sem alterações significantes para o Grupo III (Colado), concordando com os autores que demonstraram um maior controle vertical durante a $E R M$ com o aparelho colado 5,9,29,35,59,66,67,69,78,83. Apesar desta diferença observada no Grupo III, ao se realizar comparações entre as diferenças médias nas três fases estudadas, ilustradas nas Tabelas 5.13 e 5.15 (p.122 a 124), conclui-se que não existiram 
diferenças estatisticamente significantes entre os incrementos médios analisados nas três fases do estudo, demonstrando uma semelhança nas alterações verticais decorrentes da $E R M$, realizada com os três tipos de aparelho.

Concordamos com VELÁSQUEZ; BENITO; BRAVO ${ }^{108}$, CHANG, MCNAMARA JÚNIOR; HERBERGER ${ }^{27}$, ALMEIDA; CAPELOZZA FILHO; TRINDADE JÚNIOR ${ }^{4}$ e CARREIRA ${ }^{24}$, que realizaram estudos a longo prazo, avaliando as alterações decorrentes da expansão rápida da maxila e puderam concluir que após alguns anos, este procedimento não apresentou influência sobre a posição ântero-posterior das bases ósseas apicais, não alterou o padrão de crescimento facial, as dimensões verticais da face e os trespasses horizontal e vertical e conseqüentemente, não introduziu alterações no perfil tegumentar. REED; GHOSH; NANDA ${ }^{79}$ em um estudo comparativo entre o Hyrax e o expansor colado, demonstraram que apesar de alterações verticais maiores no grupo bandado, imediatamente após a expansão, com valores mais altos para as medidas FMA e SNGoGn, a maioria das medidas analisadas, após a finalização do tratamento ortodôntico corretivo, apresentaram diferenças entre os grupos menores do que um grau ou um milímetro, ou seja, clinicamente insignificantes, portanto, nenhum aparelho demonstrou superioridade quando comparados.

Conclui-se que, apesar da pequena superioridade do expansor colado no controle vertical, enfatizada nas publicações pertinentes ${ }^{5,9,29,35,59,66,67,69,78,83}$, os três aparelhos apresentaram respostas semelhantes após a ERM. Baseados nestes dados, nos estudos longitudinais citados anteriormente e nas inconveniências clínicas trazidas pelo aparelho colado, como a dificuldade de higienização e remoção, este não apresenta grandes vantagens em comparação aos aparelhos bandados, mesmo em pacientes com crescimento excessivamente vertical, como descrito na literatura ${ }^{5,9,53,59,66,67,69,73,83,101,102,105,109}$. 


\section{8) Considerações finais}

Após a análise crítica das variáveis estudadas, constatamos que os três tipos de aparelho mostraram respostas esqueléticas semelhantes, com aumentos na porção inferior da cavidade nasal e na largura maxilar, sem alterações significantes durante a contenção. Com relação às alterações dentoalveolares, existiram pequenas diferenças, discutidas anteriormente, principalmente nas variáveis que não estavam diretamente relacionadas com a atuação dos aparelhos, ou seja, a resposta dos molares inferiores e dos incisivos superiores, concluindo-se que os três tipos de aparelhos apresentaram alterações dentoesqueléticas semelhantes e que as medidas analisadas mantiveram-se estáveis durante os três meses de contenção.

Com relação ao tipo de ancoragem utilizada pelos aparelhos, observouse que o acrílico que recobre a superfície palatina não proporcionou benefícios extras aos pacientes do Grupo I e, ao contrário, dificultou a higienização desta região, propiciando o aparecimento de estomatite subplaca e lesões ulcerativas em três $\operatorname{casos}^{65}$. O expansor com cobertura de acrílico, utilizado no Grupo III, apesar de demonstrar uma pequena superioridade no controle vertical durante a expansão, apresentou muitas desvantagens observadas clinicamente, relacionadas à alimentação, à higienização e principalmente ao procedimento de remoção do aparelho ${ }^{5,53,66,67,73}$. Diante destas conclusões e embasados em outros trabalhos ${ }^{4,24,27,55,65,79}$, cientes da efetividade destes três aparelhos na correção da atresia maxilar, observamos a vantagem do aparelho tipo Hyrax, ou seja, sem o suporte mucoso no palato e sem o recobrimento de acrílico nos dentes pósterosuperiores, para os pacientes na faixa etária deste estudo. 
7. CONCLUSÕES 


\section{CONCLUSÕES}

Segundo a metodologia aplicada e diante dos resultados obtidos para a amostra selecionada, julgamos válido afirmar :

7.1 - em relação às alterações esqueléticas decorrentes da $E R M$, que :

7.1.1 - os três grupos apresentaram alterações esqueléticas semelhantes, sendo demonstradas pelos aumentos estatisticamente significantes na largura inferior da cavidade nasal e na largura maxilar, imediatamente após a expansão, mantendo-se estáveis durante o período de contenção;

7.1.2 - não se observaram diferenças estatisticamente significantes entre os grupos para as variáveis esqueléticas;

7.2 - em relação às alterações dentárias decorrentes da $E R M$, que :

7.2.1- os molares de ancoragem apresentaram comportamentos semelhantes, principalmente nas comparações das alterações ao final do período de contenção;

7.2.2 - as distâncias intermolares inferiores aumentaram nos três grupos, porém com diferenças significativas entre o Grupo III, que apresentou pequenas alterações, e os demais grupos; 
7.2.3 - apesar de algumas diferenças estatisticamente significantes, observadas principalmente nas variáveis A1L.Z e A1R.Z, os incisivos centrais superiores demonstraram comportamentos semelhantes, durante o período de expansão e contenção, demonstradas pelas medidas AI-IA e IM-MI;

7.3 - em relação às alterações verticais provocadas pela $E R M$, que :

7.3.1 - existiram diferenças estatisticamente significantes na análise da SOBREMORDIDA, entre o Grupo I (Haas) e o Grupo II (Hyrax), uma vez que as alterações verticais imediatamente após a expansão foram maiores nos pacientes do Grupo I;

7.3.2 - nas comparações entre as variações durante a fase de contenção e a variação total, não foram observadas diferenças significantes entre os três grupos;

7.3.3 - com a análise da variável AFAI, não se observaram diferenças estatisticamente significantes entre os incrementos médios analisados nas três fases do estudo, demonstrando uma semelhança nas alterações verticais decorrentes da ERM, realizada com os três tipos de aparelho. 
ANEXOS 
ANEXO A : Valores individuais para todas as variáveis analisadas no Grupo I (Haas modificado), na fase pré-expansão.

\begin{tabular}{c|c|c|c|c|c|c|c}
\hline PACIENTE & NC-CN & JL-JR & RSR & CSC & CIC & A6-JL & 6A-JR \\
\hline 1 & 30,0 & 59,0 & 45,0 & 53,5 & 65,0 & 10,0 & 8,0 \\
\hline 2 & 30,0 & 63,0 & 55,0 & 63,0 & 63,0 & 5,0 & 5,0 \\
\hline 3 & 26,0 & 60,0 & 45,0 & 52,0 & 57,0 & 9,0 & 8,0 \\
\hline 4 & 27,0 & 59,0 & 48,0 & 53,0 & 57,0 & 8,0 & 7,0 \\
\hline 5 & 31,0 & 61,0 & 48,0 & 57,0 & 60,0 & 8,0 & 6,0 \\
\hline 6 & 33,0 & 63,0 & 52,0 & 59,0 & 57,0 & 6,0 & 5,0 \\
\hline 7 & 29,0 & 66,0 & 51,0 & 59,0 & 60,0 & 6,0 & 7,0 \\
\hline 8 & 30,0 & 60,0 & 48,0 & 53,0 & 48,5 & 10,0 & 7,0 \\
\hline 9 & 25,0 & 60,0 & 43,0 & 53,0 & 57,0 & 10,0 & 9,0 \\
\hline 10 & 29,0 & 59,0 & 47,5 & 55,0 & 55,5 & 10,0 & 7,0 \\
\hline 11 & 26,0 & 59,0 & 49,5 & 54,0 & 56,0 & 7,0 & 9,0 \\
\hline 12 & 30,0 & 60,0 & 48,0 & 54,0 & 59,0 & 7,0 & 7,0 \\
\hline 13 & 29,0 & 63,0 & 48,5 & 56,0 & 57,0 & 7,0 & 8,0 \\
\hline 14 & 25,0 & 61,0 & 45,0 & 52,0 & 55,0 & 7,0 & 9,0 \\
\hline 15 & 30,0 & 61,0 & 49,5 & 56,0 & 55,5 & 7,0 & 7,0 \\
\hline 16 & 28,0 & 57,0 & 41,5 & 52,0 & 54,5 & 8,0 & 9,0 \\
\hline 17 & 32,0 & 62,0 & 48,0 & 57,0 & 58,5 & 5,0 & 7,0 \\
\hline 18 & 29,0 & 63,0 & 50,5 & 58,0 & 53,0 & 8,0 & 8,0 \\
\hline 19 & 32,0 & 69,0 & 52,0 & 59,0 & 59,0 & 9,0 & 10,0 \\
\hline 20 & 27,5 & 60,0 & 52,5 & 58,0 & 55,0 & 6,0 & 4,0 \\
\hline
\end{tabular}

\begin{tabular}{c|c|c|c|c|c|c|c|c}
\hline PACIENTE & 6R.Z & 6L.Z & AI-IA & IM-MI & A1R.Z & A1L.Z & SOBR. & AFAI \\
\hline 1 & 75,0 & 70,0 & 6,0 & 0,0 & 83,0 & 87,0 & 0,0 & 76,0 \\
\hline 2 & 75,0 & 69,0 & 8,0 & 0,0 & 89,0 & 84,5 & $-1,0$ & 73,0 \\
\hline 3 & 85,0 & 72,0 & 8,0 & 0,0 & 81,0 & 97,0 & 2,0 & 62,0 \\
\hline 4 & 85,0 & 75,0 & 7,5 & 0,0 & 96,0 & 73,5 & 2,0 & 59,0 \\
\hline 5 & 78,0 & 66,0 & 6,0 & 0,0 & 87,5 & 85,0 & 3,0 & 67,0 \\
\hline 6 & 78,0 & 68,0 & 8,0 & 0,0 & 90,0 & 89,0 & 0,0 & 55,0 \\
\hline 7 & 83,0 & 67,0 & 10,0 & 0,0 & 101,0 & 80,0 & 0,0 & 66,0 \\
\hline 8 & 84,0 & 76,0 & 7,0 & 0,0 & 89,0 & 87,0 & 3,0 & 68,0 \\
\hline 9 & 86,0 & 67,0 & 8,0 & 0,0 & 89,0 & 88,0 & 2,0 & 67,0 \\
\hline 10 & 80,0 & 67,0 & 7,5 & 0,0 & 87,0 & 88,5 & 2,0 & 62,0 \\
\hline 11 & 84,0 & 70,0 & 7,0 & 0,0 & 87,0 & 88,0 & 0,0 & 62,0 \\
\hline 12 & 79,0 & 72,0 & 7,0 & 0,0 & 87,0 & 88,0 & 1,0 & 73,0 \\
\hline 13 & 77,5 & 72,0 & 8,0 & 0,0 & 94,0 & 85,0 & 1,0 & 68,0 \\
\hline 14 & 79,5 & 70,0 & 6,0 & 0,0 & 82,0 & 89,0 & 4,0 & 67,0 \\
\hline 15 & 73,5 & 74,0 & 5,0 & 0,0 & 84,0 & 84,0 & 1,0 & 67,0 \\
\hline 16 & 72,0 & 69,0 & 7,0 & 0,0 & 91,0 & 86,0 & 3,0 & 66,0 \\
\hline 17 & 78,5 & 67,0 & 7,0 & 0,0 & 90,0 & 88,5 & 0,0 & 55,0 \\
\hline 18 & 73,0 & 69,0 & 8,0 & 0,0 & 90,0 & 89,5 & 0,0 & 73,0 \\
\hline 19 & 82,0 & 74,0 & 7,0 & 0,0 & 89,0 & 86,5 & $-0,5$ & 67,0 \\
\hline 20 & 82,0 & 70,0 & 7,0 & 0,0 & 89,0 & 84,0 & 2,0 & 58,0 \\
\hline
\end{tabular}


ANEXO B : Valores individuais para todas as variáveis analisadas no Grupo I (Haas modificado), na fase pós-expansão.

\begin{tabular}{c|c|c|c|c|c|c|c}
\hline PACIENTE & NC-CN & JL-JR & RSR & CSC & CIC & A6-JL & 6A-JR \\
\hline 1 & 34,0 & 61,0 & 54,0 & 62,0 & 65,5 & 6,5 & 5,0 \\
\hline 2 & 32,0 & 67,0 & 60,5 & 71,0 & 65,0 & 3,0 & 4,0 \\
\hline 3 & 28,0 & 63,0 & 50,0 & 59,0 & 57,0 & 6,0 & 6,0 \\
\hline 4 & 27,0 & 59,0 & 50,0 & 57,0 & 56,0 & 5,0 & 3,5 \\
\hline 5 & 32,0 & 61,0 & 49,0 & 58,0 & 60,0 & 8,0 & 7,0 \\
\hline 6 & 34,0 & 64,0 & 57,0 & 63,0 & 58,0 & 6,0 & 5,0 \\
\hline 7 & 33,0 & 67,0 & 57,0 & 65,0 & 62,0 & 3,0 & 8,0 \\
\hline 8 & 30,0 & 60,0 & 47,0 & 54,0 & 47,0 & 8,0 & 6,0 \\
\hline 9 & 27,0 & 61,0 & 50,0 & 59,0 & 57,0 & 7,0 & 5,0 \\
\hline 10 & 31,0 & 62,0 & 52,5 & 61,0 & 59,0 & 7,0 & 5,0 \\
\hline 11 & 30,0 & 62,0 & 51,0 & 63,0 & 54,0 & 5,0 & 5,5 \\
\hline 12 & 30,0 & 64,0 & 53,0 & 61,0 & 59,0 & 6,0 & 5,0 \\
\hline 13 & 32,0 & 64,5 & 57,0 & 64,0 & 57,0 & 5,0 & 4,0 \\
\hline 14 & 28,0 & 64,0 & 52,0 & 60,5 & 56,0 & 5,0 & 7,0 \\
\hline 15 & 32,0 & 64,0 & 53,0 & 52,0 & 57,0 & 5,5 & 5,5 \\
\hline 16 & 30,0 & 60,0 & 43,5 & 53,0 & 53,5 & 7,0 & 9,0 \\
\hline 17 & 33,0 & 67,0 & 53,0 & 62,0 & 58,5 & 7,0 & 4,0 \\
\hline 18 & 31,0 & 67,0 & 55,0 & 62,0 & 57,0 & 9,0 & 6,0 \\
\hline 19 & 33,0 & 68,0 & 58,0 & 65,0 & 60,0 & 5,0 & 6,0 \\
\hline 20 & 30,0 & 63,0 & 54,5 & 61,5 & 56,0 & 5,0 & 5,0 \\
\hline
\end{tabular}

\begin{tabular}{c|c|c|c|c|c|c|c|c}
\hline PACIENTE & 6R.Z & 6L.Z & AI-IA & IM-MI & A1R.Z & A1L.Z & SOBR. & AFAI \\
\hline 1 & 71,5 & 75,5 & 13,0 & 4,0 & 86,0 & 93,0 & $-1,5$ & 77,0 \\
\hline 2 & 73,5 & 57,0 & 12,0 & 2,0 & 95,0 & 85,0 & $-2,0$ & 79,0 \\
\hline 3 & 81,0 & 69,0 & 11,0 & 3,0 & 83,5 & 95,5 & 0,0 & 66,0 \\
\hline 4 & 83,0 & 65,0 & 10,0 & 2,0 & 99,0 & 79,0 & 2,0 & 63,0 \\
\hline 5 & 74,0 & 71,0 & 6,0 & 2,0 & 86,0 & 84,5 & 0,0 & 72,0 \\
\hline 6 & 83,0 & 72,0 & 12,0 & 3,0 & 98,0 & 90,0 & $-2,0$ & 59,0 \\
\hline 7 & 78,0 & 67,0 & 14,0 & 3,0 & 101,0 & 83,0 & $-2,0$ & 68,0 \\
\hline 8 & 77,0 & 69,0 & 11,0 & 3,0 & 91,0 & 90,0 & 1,0 & 70,0 \\
\hline 9 & 72,0 & 67,0 & 12,0 & 3,0 & 89,0 & 90,0 & $-1,0$ & 70,0 \\
\hline 10 & 73,0 & 63,0 & 13,0 & 4,0 & 90,0 & 92,0 & $-1,0$ & 64,0 \\
\hline 11 & 64,0 & 57,0 & 7,0 & 2,0 & 78,0 & 84,0 & $-3,0$ & 64,0 \\
\hline 12 & 69,0 & 72,0 & 7,0 & 1,0 & 87,0 & 83,0 & 1,0 & 73,0 \\
\hline 13 & 81,0 & 75,0 & 10,0 & 3,0 & 89,0 & 86,5 & $-1,0$ & 69,0 \\
\hline 14 & 74,0 & 68,0 & 11,0 & 5,0 & 84,0 & 91,0 & 0,0 & 70,0 \\
\hline 15 & 67,0 & 86,0 & 9,0 & 2,0 & 85,0 & 94,0 & 0,5 & 68,0 \\
\hline 16 & 73,0 & 67,0 & 10,0 & 1,0 & 85,5 & 96,0 & 0,0 & 68,0 \\
\hline 17 & 66,0 & 68,0 & 9,0 & 3,0 & 83,0 & 86,0 & $-3,0$ & 59,0 \\
\hline 18 & 87,0 & 68,0 & 13,0 & 4,0 & 90,0 & 91,5 & $-1,0$ & 75,0 \\
\hline 19 & 76,0 & 76,0 & 10,0 & 2,0 & 86,0 & 91,0 & $-3,0$ & 69,0 \\
\hline 20 & 83,0 & 70,0 & 13,0 & 3,0 & 93,0 & 95,0 & 0,0 & 61,0 \\
\hline
\end{tabular}


ANEXO C : Valores individuais para todas as variáveis analisadas no Grupo I (Haas modificado), na fase pós-contenção.

\begin{tabular}{c|c|c|c|c|c|c|c}
\hline PACIENTE & NC-CN & JL-JR & RSR & CSC & CIC & A6-JL & 6A-JR \\
\hline 1 & 32,0 & 60,5 & 53,0 & 61,0 & 67,0 & 6,0 & 7,0 \\
\hline 2 & 33,0 & 67,0 & 57,0 & 71,0 & 65,0 & 2,0 & 3,0 \\
\hline 3 & 27,0 & 61,0 & 50,0 & 59,0 & 56,0 & 5,0 & 5,0 \\
\hline 4 & 28,0 & 59,0 & 48,5 & 59,0 & 61,0 & 5,0 & 4,0 \\
\hline 5 & 32,0 & 61,0 & 50,0 & 58,0 & 57,0 & 8,0 & 6,0 \\
\hline 6 & 36,0 & 63,0 & 51,0 & 65,0 & 62,0 & 5,0 & 3,0 \\
\hline 7 & 32,0 & 68,0 & 59,0 & 66,0 & 62,0 & 4,0 & 6,0 \\
\hline 8 & 30,0 & 60,0 & 51,0 & 57,0 & 51,5 & 8,0 & 5,0 \\
\hline 9 & 27,0 & 62,0 & 56,0 & 61,0 & 56,0 & 6,0 & 7,0 \\
\hline 10 & 32,0 & 61,0 & 50,0 & 61,0 & 59,0 & 7,0 & 5,5 \\
\hline 11 & 29,0 & 62,0 & 51,0 & 57,0 & 56,0 & 7,0 & 8,0 \\
\hline 12 & 30,0 & 62,0 & 54,5 & 63,0 & 58,0 & 6,0 & 5,0 \\
\hline 13 & 32,0 & 65,0 & 57,0 & 65,0 & 59,0 & 5,0 & 5,0 \\
\hline 14 & 28,0 & 64,0 & 50,0 & 58,0 & 57,0 & 7,0 & 7,0 \\
\hline 15 & 31,0 & 63,0 & 53,5 & 63,0 & 56,0 & 6,0 & 4,0 \\
\hline 16 & 30,0 & 60,0 & 49,0 & 56,0 & 55,0 & 8,0 & 7,0 \\
\hline 17 & 35,0 & 63,5 & 54,5 & 62,0 & 59,5 & 6,0 & 3,0 \\
\hline 18 & 31,0 & 66,0 & 51,0 & 61,0 & 60,0 & 7,0 & 8,0 \\
\hline 19 & 36,0 & 68,0 & 58,0 & 66,0 & 60,0 & 4,0 & 4,5 \\
\hline 20 & 30,0 & 63,0 & 54,0 & 62,0 & 59,5 & 7,0 & 3,0 \\
\hline
\end{tabular}

\begin{tabular}{c|c|c|c|c|c|c|c|c}
\hline PACIENTE & 6R.Z & 6L.Z & AI-IA & IM-MI & A1R.Z & A1L.Z & SOBR. & AFAI \\
\hline 1 & 74,0 & 73,0 & 12,0 & 0,0 & 92,0 & 95,0 & 2,5 & 76,0 \\
\hline 2 & 61,0 & 62,0 & 11,0 & 0,0 & 92,0 & 93,0 & 0,0 & 77,0 \\
\hline 3 & 81,0 & 64,0 & 9,0 & 0,0 & 81,0 & 84,0 & 1,0 & 66,0 \\
\hline 4 & 78,0 & 67,0 & 6,0 & 0,0 & 86,0 & 78,0 & 4,0 & 62,0 \\
\hline 5 & 78,5 & 68,0 & 7,0 & 0,0 & 90,0 & 87,5 & 1,0 & 71,0 \\
\hline 6 & 68,0 & 72,0 & 13,0 & 0,0 & 97,0 & 99,0 & 0,0 & 62,0 \\
\hline 7 & 79,0 & 71,0 & 14,0 & 3,0 & 95,0 & 90,0 & 0,0 & 67,0 \\
\hline 8 & 84,0 & 70,0 & 10,0 & 0,0 & 87,0 & 93,0 & 4,0 & 70,0 \\
\hline 9 & 72,0 & 67,0 & 11,0 & 0,0 & 93,0 & 94,0 & 0,0 & 72,0 \\
\hline 10 & 66,0 & 60,0 & 11,5 & 0,0 & 95,0 & 93,0 & 1,0 & 64,0 \\
\hline 11 & 80,0 & 72,0 & 8,0 & 0,0 & 90,0 & 87,0 & 0,0 & 64,0 \\
\hline 12 & 71,0 & 70,0 & 8,0 & 0,0 & 91,0 & 83,0 & 2,0 & 72,0 \\
\hline 13 & 77,0 & 67,0 & 10,0 & 0,0 & 99,0 & 89,0 & 0,0 & 68,0 \\
\hline 14 & 80,0 & 66,0 & 11,0 & 0,0 & 90,0 & 82,0 & 2,0 & 68,0 \\
\hline 15 & 65,0 & 68,0 & 6,0 & 0,0 & 87,0 & 83,0 & 0,5 & 65,0 \\
\hline 16 & 77,0 & 75,0 & 10,0 & 0,0 & 88,0 & 95,0 & 1,0 & 68,0 \\
\hline 17 & 77,0 & 65,0 & 7,0 & 0,0 & 94,0 & 90,0 & 0,0 & 57,0 \\
\hline 18 & 64,0 & 69,0 & 12,0 & 0,0 & 97,0 & 99,0 & 0,0 & 75,0 \\
\hline 19 & 73,5 & 67,0 & 12,0 & 0,0 & 93,0 & 97,0 & $-2,0$ & 69,0 \\
\hline 20 & 76,0 & 60,0 & 10,0 & 0,0 & 93,0 & 95,0 & 1,0 & 60,0 \\
\hline
\end{tabular}


ANEXO D : Valores individuais para todas as variáveis analisadas no Grupo II (Hyrax modificado), na fase pré-expansão.

\begin{tabular}{c|c|c|c|c|c|c|c}
\hline PACIENTE & NC-CN & JL-JR & RSR & CSC & CIC & A6-JL & 6A-JR \\
\hline 1 & 29,0 & 62,0 & 47,0 & 52,0 & 53,0 & 9,0 & 8,0 \\
\hline 2 & 30,0 & 61,0 & 48,0 & 53,0 & 56,0 & 11,0 & 7,0 \\
\hline 3 & 32,0 & 60,0 & 50,5 & 58,0 & 61,0 & 4,0 & 4,0 \\
\hline 4 & 26,0 & 61,0 & 46,0 & 52,0 & 55,0 & 9,0 & 9,0 \\
\hline 5 & 33,0 & 66,0 & 52,0 & 58,0 & 55,0 & 9,0 & 7,0 \\
\hline 6 & 24,0 & 64,0 & 50,0 & 59,0 & 64,0 & 6,0 & 7,0 \\
\hline 7 & 29,0 & 65,0 & 46,0 & 54,0 & 56,0 & 10,0 & 10,0 \\
\hline 8 & 32,0 & 62,0 & 49,5 & 58,0 & 58,5 & 9,0 & 8,0 \\
\hline 9 & 31,0 & 67,0 & 54,0 & 61,0 & 64,0 & 8,0 & 6,0 \\
\hline 10 & 26,0 & 58,0 & 43,0 & 50,5 & 57,0 & 10,0 & 8,0 \\
\hline 11 & 30,0 & 66,0 & 49,0 & 57,0 & 56,0 & 11,0 & 9,0 \\
\hline 12 & 26,0 & 63,0 & 49,0 & 56,5 & 59,0 & 8,0 & 8,0 \\
\hline 13 & 29,0 & 62,0 & 48,0 & 54,5 & 64,0 & 6,0 & 7,0 \\
\hline 14 & 29,0 & 56,0 & 41,0 & 51,0 & 59,0 & 6,0 & 7,0 \\
\hline 15 & 28,0 & 59,0 & 49,0 & 56,0 & 59,0 & 8,0 & 8,0 \\
\hline 16 & 24,0 & 59,0 & 46,0 & 55,5 & 57,0 & 8,0 & 9,0 \\
\hline 17 & 28,0 & 63,0 & 49,0 & 57,0 & 55,0 & 5,0 & 6,0 \\
\hline 18 & 34,0 & 61,0 & 45,5 & 58,0 & 59,0 & 8,0 & 6,0 \\
\hline 19 & 34,0 & 65,0 & 58,0 & 56,0 & 57,0 & 7,5 & 5,0 \\
\hline 20 & 33,0 & 62,0 & 49,5 & 57,0 & 58,0 & 9,5 & 8,5 \\
\hline 21 & 30,0 & 57,0 & 44,5 & 53,0 & 54,0 & 8,0 & 8,0 \\
\hline
\end{tabular}

\begin{tabular}{c|c|c|c|c|c|c|c|c}
\hline PACIENTE & 6R.Z & 6L.Z & AI-IA & IM-MI & A1R.Z & A1L.Z & SOBR. & AFAI \\
\hline 1 & 85,0 & 75,0 & 8,0 & 0,0 & 88,0 & 88,0 & 3,0 & 59,0 \\
\hline 2 & 83,0 & 79,0 & 6,0 & 0,0 & 85,0 & 86,0 & 5,0 & 68,0 \\
\hline 3 & 80,0 & 70,0 & 6,0 & 0,0 & 88,0 & 87,0 & 1,0 & 55,0 \\
\hline 4 & 82,0 & 73,0 & 4,0 & 0,0 & 81,0 & 79,0 & 5,0 & 61,0 \\
\hline 5 & 87,0 & 69,0 & 7,0 & 0,0 & 90,0 & 87,0 & $-3,0$ & 63,0 \\
\hline 6 & 72,0 & 71,0 & 6,0 & 0,0 & 88,0 & 91,0 & $-3,0$ & 70,0 \\
\hline 7 & 80,0 & 74,0 & 8,0 & 0,0 & 85,0 & 95,0 & 1,0 & 67,0 \\
\hline 8 & 77,0 & 67,0 & 3,0 & 0,0 & 79,0 & 80,0 & 0,0 & 61,0 \\
\hline 9 & 79,0 & 72,0 & 6,0 & 0,0 & 93,0 & 76,0 & 0,0 & 69,0 \\
\hline 10 & 81,0 & 69,0 & 5,0 & 0,0 & 85,0 & 78,0 & $-3,0$ & 60,0 \\
\hline 11 & 77,0 & 67,0 & 7,0 & 0,0 & 84,0 & 91,0 & 3,0 & 70,0 \\
\hline 12 & 79,0 & 70,0 & 6,0 & 0,0 & 85,0 & 85,0 & 1,0 & 61,0 \\
\hline 13 & 86,0 & 69,0 & 8,0 & 0,0 & 90,0 & 89,0 & 0,0 & 60,0 \\
\hline 14 & 70,0 & 66,0 & 6,0 & 0,0 & 83,0 & 87,0 & 0,0 & 59,0 \\
\hline 15 & 75,0 & 69,0 & 9,0 & 0,0 & 88,0 & 95,0 & 3,0 & 64,0 \\
\hline 16 & 73,0 & 68,0 & 6,0 & 0,0 & 88,0 & 82,0 & 2,0 & 62,0 \\
\hline 17 & 81,0 & 67,0 & 9,0 & 0,0 & 90,0 & 94,0 & 1,0 & 66,0 \\
\hline 18 & 72,0 & 62,0 & 7,0 & 0,0 & 87,0 & 89,0 & 1,0 & 74,0 \\
\hline 19 & 79,0 & 66,0 & 7,0 & 0,0 & 90,0 & 88,0 & 0,0 & 67,0 \\
\hline 20 & 77,0 & 69,0 & 7,0 & 0,0 & 87,0 & 87,0 & 1,0 & 62,0 \\
\hline 21 & 77,0 & 65,0 & 7,0 & 0,0 & 94,0 & 85,0 & 1,0 & 68,0 \\
\hline
\end{tabular}


ANEXO E : Valores individuais para todas as variáveis analisadas no Grupo II (Hyrax modificado), na fase pós-expansão.

\begin{tabular}{c|c|c|c|c|c|c|c}
\hline PACIENTE & NC-CN & JL-JR & RSR & CSC & CIC & A6-JL & 6A-JR \\
\hline 1 & 29,0 & 62,0 & 51,0 & 59,0 & 55,0 & 6,0 & 6,0 \\
\hline 2 & 31,0 & 64,0 & 50,0 & 58,5 & 57,0 & 8,0 & 7,0 \\
\hline 3 & 33,0 & 61,0 & 54,0 & 64,0 & 61,0 & 2,0 & 2,0 \\
\hline 4 & 29,0 & 61,0 & 47,0 & 58,0 & 55,0 & 5,5 & 5,5 \\
\hline 5 & 33,0 & 68,0 & 56,0 & 61,0 & 58,0 & 8,0 & 6,0 \\
\hline 6 & 26,0 & 64,0 & 55,0 & 64,0 & 66,0 & 6,0 & 5,0 \\
\hline 7 & 32,0 & 66,0 & 52,0 & 60,0 & 58,0 & 8,0 & 7,0 \\
\hline 8 & 33,0 & 65,0 & 56,0 & 64,0 & 58,5 & 6,0 & 6,5 \\
\hline 9 & 34,0 & 69,0 & 60,0 & 69,0 & 67,0 & 6,0 & 2,5 \\
\hline 10 & 27,0 & 59,0 & 48,0 & 58,0 & 57,0 & 6,0 & 6,0 \\
\hline 11 & 33,0 & 69,0 & 57,0 & 64,0 & 58,0 & 9,0 & 8,0 \\
\hline 12 & 30,0 & 67,0 & 57,0 & 66,0 & 61,0 & 7,0 & 4,0 \\
\hline 13 & 32,0 & 67,0 & 56,0 & 63,0 & 63,0 & 4,0 & 4,0 \\
\hline 14 & 32,0 & 60,0 & 47,0 & 56,0 & 59,0 & 5,0 & 6,0 \\
\hline 15 & 30,0 & 61,0 & 50,0 & 60,0 & 58,0 & 5,0 & 7,0 \\
\hline 16 & 27,0 & 61,0 & 48,0 & 60,0 & 57,0 & 6,0 & 9,0 \\
\hline 17 & 31,0 & 66,0 & 51,0 & 59,0 & 57,0 & 6,0 & 4,0 \\
\hline 18 & 35,0 & 64,0 & 54,0 & 63,0 & 60,0 & 4,0 & 4,0 \\
\hline 19 & 36,0 & 67,0 & 55,0 & 63,0 & 58,0 & 4,0 & 4,0 \\
\hline 20 & 33,0 & 63,0 & 52,0 & 62,0 & 60,0 & 9,0 & 7,0 \\
\hline 21 & 30,0 & 60,0 & 47,5 & 58,0 & 54,0 & 6,0 & 7,0 \\
\hline
\end{tabular}

\begin{tabular}{c|c|c|c|c|c|c|c|c}
\hline PACIENTE & 6R.Z & 6L.Z & AI-IA & IM-MI & A1R.Z & A1L.Z & SOBR. & AFAI \\
\hline 1 & 77,0 & 69,0 & 8,0 & 0,0 & 93,5 & 89,0 & 1,0 & 62,0 \\
\hline 2 & 79,0 & 65,5 & 10,0 & 3,5 & 88,0 & 83,0 & 2,0 & 72,0 \\
\hline 3 & 74,0 & 66,0 & 8,0 & 3,0 & 89,0 & 82,0 & $-1,0$ & 59,0 \\
\hline 4 & 70,5 & 60,0 & 4,5 & 3,5 & 76,0 & 79,0 & 3,0 & 65,0 \\
\hline 5 & 85,0 & 78,0 & 8,0 & 2,0 & 90,0 & 85,0 & 1,0 & 68,0 \\
\hline 6 & 81,0 & 60,0 & 7,0 & 3,0 & 87,0 & 90,0 & $-3,0$ & 71,0 \\
\hline 7 & 83,0 & 71,0 & 14,0 & 4,0 & 87,0 & 95,0 & 0,0 & 69,0 \\
\hline 8 & 79,0 & 65,0 & 12,0 & 4,0 & 96,0 & 79,0 & $-1,0$ & 63,0 \\
\hline 9 & 74,0 & 63,0 & 14,0 & 4,0 & 98,0 & 80,0 & $-2,0$ & 70,0 \\
\hline 10 & 73,0 & 64,0 & 7,0 & 3,0 & 87,0 & 73,0 & $-1,0$ & 60,0 \\
\hline 11 & 81,0 & 69,0 & 12,5 & 4,5 & 91,0 & 86,0 & 0,0 & 72,0 \\
\hline 12 & 70,0 & 67,0 & 7,0 & 4,0 & 88,0 & 75,0 & 0,5 & 65,0 \\
\hline 13 & 81,0 & 75,0 & 14,0 & 7,0 & 83,0 & 87,0 & $-3,0$ & 61,0 \\
\hline 14 & 72,0 & 68,0 & 12,0 & 4,0 & 87,0 & 91,0 & $-2,0$ & 63,0 \\
\hline 15 & 66,5 & 66,0 & 11,0 & 1,0 & 89,0 & 97,0 & 1,0 & 65,0 \\
\hline 16 & 62,0 & 65,0 & 10,0 & 3,0 & 87,0 & 87,0 & 0,0 & 63,0 \\
\hline 17 & 84,5 & 65,0 & 11,0 & 3,0 & 89,5 & 90,5 & 2,0 & 70,0 \\
\hline 18 & 71,0 & 66,0 & 9,0 & 3,0 & 88,0 & 90,0 & $-1,0$ & 75,0 \\
\hline 19 & 75,0 & 73,0 & 12,0 & 3,0 & 98,0 & 84,0 & $-1,0$ & 70,0 \\
\hline 20 & 69,0 & 63,0 & 9,0 & 3,0 & 88,0 & 86,0 & 0,5 & 64,0 \\
\hline 21 & 75,0 & 61,0 & 8,0 & 2,5 & 90,0 & 79,0 & 0,0 & 70,0 \\
\hline
\end{tabular}


ANEXO F : Valores individuais para todas as variáveis analisadas no Grupo II (Hyrax modificado), na fase pós-contenção.

\begin{tabular}{c|c|c|c|c|c|c|c}
\hline PACIENTE & NC-CN & JL-JR & RSR & CSC & CIC & A6-JL & 6A-JR \\
\hline 1 & 29,0 & 61,0 & 51,0 & 59,0 & 55,0 & 7,0 & 5,0 \\
\hline 2 & 31,0 & 65,0 & 54,0 & 59,5 & 56,0 & 6,0 & 7,0 \\
\hline 3 & 33,0 & 62,0 & 57,0 & 64,5 & 61,0 & 1,0 & 1,0 \\
\hline 4 & 29,0 & 62,0 & 50,0 & 59,0 & 57,0 & 6,0 & 7,0 \\
\hline 5 & 34,0 & 68,0 & 54,5 & 61,0 & 57,0 & 9,0 & 6,0 \\
\hline 6 & 29,0 & 64,0 & 55,0 & 63,0 & 62,0 & 5,0 & 5,0 \\
\hline 7 & 32,0 & 65,0 & 49,0 & 58,0 & 57,0 & 9,0 & 8,0 \\
\hline 8 & 34,0 & 65,0 & 53,5 & 65,0 & 60,0 & 4,0 & 7,0 \\
\hline 9 & 33,0 & 68,0 & 60,0 & 69,0 & 66,0 & 6,0 & 3,5 \\
\hline 10 & 29,0 & 60,0 & 46,0 & 55,5 & 57,0 & 7,0 & 6,0 \\
\hline 11 & 32,0 & 69,0 & 55,5 & 62,0 & 58,0 & 8,0 & 8,5 \\
\hline 12 & 30,0 & 64,0 & 57,0 & 66,0 & 60,0 & 3,0 & 3,0 \\
\hline 13 & 32,0 & 66,0 & 57,0 & 64,0 & 64,0 & 3,0 & 4,0 \\
\hline 14 & 33,5 & 61,5 & 54,0 & 61,0 & 59,0 & 5,0 & 3,0 \\
\hline 15 & 30,0 & 61,0 & 51,0 & 61,0 & 59,0 & 6,0 & 7,0 \\
\hline 16 & 28,0 & 61,0 & 49,5 & 59,5 & 57,0 & 5,0 & 7,0 \\
\hline 17 & 31,0 & 65,0 & 55,0 & 62,0 & 56,5 & 5,0 & 4,0 \\
\hline 18 & 36,0 & 64,0 & 54,0 & 63,0 & 59,0 & 6,0 & 5,0 \\
\hline 19 & 36,0 & 67,0 & 56,0 & 63,0 & 59,5 & 5,5 & 5,0 \\
\hline 20 & 35,0 & 63,0 & 52,5 & 61,0 & 59,0 & 8,0 & 7,0 \\
\hline 21 & 30,0 & 59,0 & 47,5 & 57,5 & 56,0 & 7,5 & 7,0 \\
\hline
\end{tabular}

\begin{tabular}{c|c|c|c|c|c|c|c|c}
\hline PACIENTE & 6R.Z & 6L.Z & AI-IA & IM-MI & A1R.Z & A1L.Z & SOBR. & AFAI \\
\hline 1 & 80,0 & 66,0 & 9,0 & 0,0 & 94,0 & 90,0 & 2,0 & 60,0 \\
\hline 2 & 83,5 & 69,0 & 10,0 & 0,0 & 96,0 & 84,0 & 3,0 & 71,0 \\
\hline 3 & 78,0 & 69,0 & 8,0 & 0,0 & 93,0 & 85,0 & 1,0 & 56,0 \\
\hline 4 & 76,5 & 67,5 & 7,0 & 0,0 & 83,5 & 89,0 & 3,0 & 63,0 \\
\hline 5 & 78,0 & 70,0 & 10,0 & 1,0 & 93,0 & 92,0 & 0,0 & 66,0 \\
\hline 6 & 65,0 & 72,0 & 9,0 & 2,0 & 84,0 & 91,0 & $-2,0$ & 69,0 \\
\hline 7 & 74,0 & 71,0 & 15,0 & 0,0 & 94,0 & 107,0 & 1,0 & 68,5 \\
\hline 8 & 63,0 & 59,0 & 9,0 & 0,0 & 90,0 & 94,0 & 1,0 & 62,0 \\
\hline 9 & 68,0 & 64,0 & 11,0 & 0,0 & 95,0 & 90,0 & 0,0 & 72,0 \\
\hline 10 & 82,0 & 60,0 & 7,0 & 0,0 & 89,0 & 82,0 & 1,0 & 59,0 \\
\hline 11 & 81,0 & 68,0 & 14,0 & 0,0 & 98,0 & 97,0 & 3,0 & 70,0 \\
\hline 12 & 68,0 & 67,0 & 8,0 & 0,0 & 93,0 & 87,0 & 1,0 & 63,0 \\
\hline 13 & 87,0 & 69,0 & 13,0 & 1,0 & 93,0 & 83,0 & 1,0 & 60,0 \\
\hline 14 & 80,0 & 67,0 & 12,0 & 0,0 & 96,0 & 100,0 & 0,5 & 60,0 \\
\hline 15 & 71,0 & 69,0 & 11,0 & 0,0 & 90,0 & 100,0 & 1,0 & 64,0 \\
\hline 16 & 70,0 & 65,0 & 9,0 & 0,0 & 90,0 & 92,0 & 0,0 & 67,0 \\
\hline 17 & 82,0 & 70,0 & 12,0 & 0,0 & 100,5 & 92,0 & 0,0 & 71,0 \\
\hline 18 & 72,0 & 67,0 & 11,0 & 0,0 & 94,0 & 96,0 & 0,0 & 75,0 \\
\hline 19 & 78,0 & 72,0 & 11,0 & 0,0 & 99,0 & 91,0 & 0,5 & 70,0 \\
\hline 20 & 79,0 & 67,0 & 8,5 & 0,0 & 89,0 & 90,0 & 0,5 & 65,0 \\
\hline 21 & 74,0 & 62,0 & 7,0 & 0,0 & 87,0 & 90,0 & 1,0 & 68,0 \\
\hline
\end{tabular}


ANEXO G : Valores individuais para todas as variáveis analisadas no Grupo III (expansor colado), na fase pré-expansão.

\begin{tabular}{c|c|c|c|c|c|c|c}
\hline PACIENTE & NC-CN & JL-JR & RSR & CSC & CIC & A6-JL & 6A-JR \\
\hline 1 & 28,1 & 58,2 & 43,1 & 51,9 & 55,3 & 6,7 & 5,8 \\
\hline 2 & 26,2 & 61,1 & 42,7 & 49,5 & 54,3 & 6,7 & 8,7 \\
\hline 3 & 28,1 & 62,1 & 50,4 & 56,3 & 59,2 & 9,7 & 10,6 \\
\hline 4 & 27,1 & 60,1 & 50,4 & 56,3 & 61,1 & 6,7 & 7,7 \\
\hline 5 & 20,3 & 58,2 & 44,6 & 50,4 & 59,2 & 10,6 & 10,6 \\
\hline 6 & 28,1 & 62,1 & 46,1 & 49,5 & 57,7 & 12,6 & 12,6 \\
\hline 7 & 25,2 & 60,1 & 49,5 & 52,4 & 55,3 & 7,7 & 8,2 \\
\hline 8 & 24,2 & 55,3 & 45,6 & 54,3 & 56,3 & 7,7 & 7,7 \\
\hline 9 & 26,2 & 57,7 & 44,6 & 51,4 & 56,7 & 7,7 & 6,7 \\
\hline 10 & 25,2 & 60,1 & 50,4 & 53,3 & 56,3 & 7,7 & 5,8 \\
\hline 11 & 28,1 & 63,0 & 45,6 & 50,4 & 52,4 & 9,7 & 10,6 \\
\hline 12 & 26,2 & 54,3 & 43,6 & 48,5 & 54,3 & 9,7 & 8,7 \\
\hline 13 & 28,1 & 64,0 & 46,5 & 51,4 & 56,3 & 12,6 & 11,1 \\
\hline 14 & 28,1 & 55,8 & 38,8 & 45,6 & 48,5 & 11,6 & 11,6 \\
\hline 15 & 26,2 & 60,1 & 50,4 & 53,3 & 55,3 & 10,6 & 6,7 \\
\hline 16 & 30,0 & 66,0 & 53,3 & 58,2 & 59,2 & 7,7 & 8,7 \\
\hline 17 & 27,1 & 62,1 & 50,4 & 58,7 & 58,2 & 7,7 & 3,8 \\
\hline 18 & 26,2 & 60,6 & 44,6 & 51,4 & 56,3 & 9,7 & 7,7 \\
\hline 19 & 30,0 & 62,1 & 51,4 & 54,3 & 55,3 & 7,7 & 8,7 \\
\hline 20 & 28,1 & 61,1 & 47,5 & 51,4 & 56,3 & 10,6 & 9,7 \\
\hline 21 & 29,1 & 64,0 & 53,3 & 56,7 & 59,2 & 6,7 & 9,7 \\
\hline 22 & 30,0 & 63,0 & 45,6 & 48,5 & 54,3 & 9,7 & 12,6 \\
\hline
\end{tabular}

\begin{tabular}{c|c|c|c|c|c|c|c|c}
\hline PACIENTE & 6R.Z & 6L.Z & AI-IA & IM-MI & A1R.Z & A1L.Z & SOBR. & AFAI \\
\hline 1 & 75,0 & 78,0 & 2,9 & 0,9 & 78,0 & 84,0 & 0,9 & 61,6 \\
\hline 2 & 80,0 & 78,0 & 5,8 & 0,9 & 86,0 & 84,5 & 0,0 & 57,2 \\
\hline 3 & 77,5 & 84,0 & 7,7 & 0,9 & 90,0 & 83,0 & 2,9 & 69,8 \\
\hline 4 & 78,0 & 82,0 & 6,7 & 0,0 & 89,0 & 87,0 & 0,0 & 66,0 \\
\hline 5 & 77,0 & 78,0 & 5,8 & 0,0 & 86,0 & 84,0 & 1,9 & 58,2 \\
\hline 6 & 76,0 & 92,0 & 7,7 & 0,0 & 92,0 & 85,0 & $-1,0$ & 73,7 \\
\hline 7 & 89,0 & 85,0 & 5,8 & 0,9 & 86,0 & 87,0 & 0,9 & 72,8 \\
\hline 8 & 73,0 & 84,0 & 3,8 & 0,9 & 86,0 & 81,0 & 2,9 & 60,1 \\
\hline 9 & 78,0 & 82,0 & 7,7 & 0,0 & 91,0 & 87,0 & 4,8 & 49,5 \\
\hline 10 & 86,0 & 83,0 & 6,7 & 0,0 & 89,0 & 87,0 & 0,9 & 60,1 \\
\hline 11 & 81,0 & 84,0 & 7,7 & 0,0 & 91,0 & 89,0 & 0,0 & 56,3 \\
\hline 12 & 83,0 & 89,0 & 8,7 & 0,0 & 91,0 & 90,0 & 2,9 & 62,1 \\
\hline 13 & 77,0 & 79,0 & 7,7 & 0,0 & 92,0 & 89,0 & $-3,9$ & 76,6 \\
\hline 14 & 79,0 & 85,0 & 4,8 & 0,0 & 94,0 & 76,0 & 0,0 & 72,8 \\
\hline 15 & 81,0 & 88,0 & 6,7 & 0,0 & 92,0 & 87,0 & $-1,0$ & 70,8 \\
\hline 16 & 79,0 & 91,0 & 6,7 & 2,9 & 87,0 & 85,0 & 1,9 & 60,1 \\
\hline 17 & 77,0 & 79,0 & 8,2 & 0,4 & 90,0 & 89,0 & 1,4 & 59,2 \\
\hline 18 & 78,0 & 83,0 & 5,8 & 0,0 & 83,5 & 90,0 & 1,9 & 61,1 \\
\hline 19 & 85,0 & 86,0 & 7,7 & 0,0 & 88,0 & 92,5 & 3,8 & 68,9 \\
\hline 20 & 81,0 & 86,0 & 6,7 & 0,9 & 90,0 & 83,0 & 3,8 & 70,8 \\
\hline 21 & 83,0 & 87,0 & 6,7 & 0,9 & 83,5 & 87,0 & 2,9 & 65,0 \\
\hline 22 & 81,0 & 87,0 & 6,7 & 0,0 & 88,0 & 88,0 & 1,9 & 66,9 \\
\hline
\end{tabular}


ANEXO $\mathrm{H}$ : Valores individuais para todas as variáveis analisadas no Grupo III (expansor colado), na fase pós-expansão.

\begin{tabular}{c|c|c|c|c|c|c|c}
\hline PACIENTE & NC-CN & JL-JR & RSR & CSC & CIC & A6-JL & 6A-JR \\
\hline 1 & 30,0 & 63,0 & 47,5 & 57,2 & 55,3 & 5,8 & 5,8 \\
\hline 2 & 29,1 & 63,0 & 46,5 & 57,2 & 54,3 & 4,8 & 4,8 \\
\hline 3 & 29,1 & 66,0 & 53,3 & 59,2 & 59,2 & 7,7 & 8,7 \\
\hline 4 & 29,1 & 62,1 & 57,2 & 64,0 & 60,1 & 4,8 & 4,8 \\
\hline 5 & 24,2 & 60,1 & 51,4 & 57,7 & 59,2 & 8,7 & 7,7 \\
\hline 6 & 28,1 & 63,0 & 51,4 & 56,3 & 57,7 & 10,6 & 10,6 \\
\hline 7 & 26,2 & 63,0 & 53,3 & 57,2 & 55,3 & 5,8 & 5,8 \\
\hline 8 & 27,1 & 59,2 & 48,5 & 59,2 & 57,2 & 5,8 & 4,8 \\
\hline 9 & 27,1 & 62,1 & 49,5 & 59,2 & 56,7 & 5,8 & 4,3 \\
\hline 10 & 27,1 & 63,0 & 56,3 & 61,1 & 56,7 & 6,7 & 3,8 \\
\hline 11 & 29,1 & 66,0 & 47,5 & 57,2 & 52,4 & 7,7 & 7,7 \\
\hline 12 & 28,1 & 56,3 & 46,5 & 56,3 & 54,3 & 5,8 & 4,8 \\
\hline 13 & 30,0 & 65,0 & 55,3 & 61,1 & 56,3 & 8,2 & 4,8 \\
\hline 14 & 30,0 & 57,2 & 42,7 & 51,4 & 49,5 & 7,7 & 10,6 \\
\hline 15 & 28,1 & 64,0 & 53,3 & 58,2 & 55,3 & 9,7 & 6,7 \\
\hline 16 & 32,0 & 67,9 & 54,3 & 63,0 & 59,2 & 6,7 & 5,8 \\
\hline 17 & 30,0 & 66,0 & 56,3 & 66,0 & 59,2 & 4,8 & 3,3 \\
\hline 18 & 28,1 & 64,0 & 53,3 & 60,1 & 57,2 & 5,8 & 6,7 \\
\hline 19 & 32,0 & 63,0 & 53,3 & 60,1 & 54,3 & 5,8 & 5,8 \\
\hline 20 & 29,1 & 63,0 & 50,4 & 56,7 & 56,3 & 7,7 & 6,3 \\
\hline 21 & 30,0 & 66,9 & 58,2 & 63,0 & 58,2 & 5,8 & 4,8 \\
\hline 22 & 33,0 & 65,0 & 52,4 & 59,2 & 55,3 & 7,2 & 8,7 \\
\hline
\end{tabular}

\begin{tabular}{c|c|c|c|c|c|c|c|c}
\hline PACIENTE & 6R.Z & 6L.Z & AI-IA & IM-MI & A1R.Z & A1L.Z & SOBR. & AFAI \\
\hline 1 & 67,0 & 74,0 & 6,7 & 2,9 & 85,0 & 85,0 & 0,0 & 0,0 \\
\hline 2 & 71,0 & 72,0 & 8,7 & 3,8 & 88,0 & 88,0 & 0,0 & 0,0 \\
\hline 3 & 75,0 & 74,0 & 10,6 & 4,3 & 92,0 & 86,0 & 0,0 & 0,0 \\
\hline 4 & 74,0 & 75,0 & 10,6 & 1,9 & 95,0 & 89,0 & 0,0 & 0,0 \\
\hline 5 & 73,0 & 76,0 & 10,6 & 3,8 & 97,0 & 97,0 & 0,0 & 0,0 \\
\hline 6 & 73,0 & 80,0 & 13,5 & 2,9 & 99,0 & 88,5 & 0,0 & 0,0 \\
\hline 7 & 86,0 & 74,0 & 12,1 & 3,8 & 87,0 & 92,0 & 0,0 & 0,0 \\
\hline 8 & 58,0 & 75,0 & 7,7 & 3,8 & 89,0 & 78,0 & 0,0 & 0,0 \\
\hline 9 & 73,0 & 75,0 & 12,6 & 2,9 & 99,0 & 93,0 & 0,0 & 0,0 \\
\hline 10 & 76,0 & 80,0 & 10,6 & 2,9 & 92,0 & 89,0 & 0,0 & 0,0 \\
\hline 11 & 72,0 & 75,5 & 10,6 & 4,8 & 90,0 & 89,0 & 0,0 & 0,0 \\
\hline 12 & 75,0 & 76,0 & 15,5 & 3,8 & 98,0 & 98,0 & 0,0 & 0,0 \\
\hline 13 & 70,0 & 73,0 & 10,6 & 2,9 & 94,0 & 89,0 & 0,0 & 0,0 \\
\hline 14 & 70,0 & 76,0 & 8,7 & 2,9 & 95,0 & 81,0 & 0,0 & 0,0 \\
\hline 15 & 79,0 & 78,0 & 12,6 & 2,9 & 98,0 & 91,5 & 0,0 & 0,0 \\
\hline 16 & 71,0 & 80,0 & 9,7 & 4,8 & 87,0 & 87,0 & 0,0 & 0,0 \\
\hline 17 & 70,0 & 86,0 & 12,6 & 3,8 & 92,0 & 92,0 & 0,0 & 0,0 \\
\hline 18 & 76,0 & 75,0 & 12,6 & 2,9 & 89,5 & 98,0 & 0,0 & 0,0 \\
\hline 19 & 70,0 & 80,0 & 12,6 & 2,9 & 91,5 & 95,5 & 0,0 & 0,0 \\
\hline 20 & 69,0 & 78,0 & 10,6 & 4,8 & 91,5 & 84,0 & 0,0 & 0,0 \\
\hline 21 & 73,0 & 84,0 & 10,6 & 3,8 & 88,0 & 89,0 & 0,0 & 0,0 \\
\hline 22 & 72,0 & 75,0 & 13,5 & 2,9 & 95,0 & 96,0 & 0,0 & 0,0 \\
\hline
\end{tabular}


ANEXO I : Valores individuais para todas as variáveis analisadas no Grupo III (expansor colado), na fase pós-contenção.

\begin{tabular}{c|c|c|c|c|c|c|c}
\hline PACIENTE & NC-CN & JL-JR & RSR & CSC & CIC & A6-JL & 6A-JR \\
\hline 1 & 30,0 & 61,1 & 49,5 & 57,2 & 55,3 & 4,8 & 4,8 \\
\hline 2 & 29,1 & 63,5 & 49,5 & 58,2 & 54,3 & 4,8 & 4,3 \\
\hline 3 & 29,1 & 64,0 & 53,3 & 59,6 & 58,2 & 6,7 & 7,7 \\
\hline 4 & 29,1 & 66,0 & 58,2 & 64,0 & 61,1 & 4,8 & 4,8 \\
\hline 5 & 24,2 & 60,1 & 51,4 & 57,2 & 60,1 & 9,7 & 7,7 \\
\hline 6 & 28,1 & 63,0 & 52,4 & 58,2 & 57,2 & 8,7 & 8,7 \\
\hline 7 & 26,2 & 63,0 & 56,3 & 60,1 & 55,3 & 4,8 & 3,8 \\
\hline 8 & 26,2 & 59,2 & 49,5 & 59,2 & 58,2 & 4,8 & 4,8 \\
\hline 9 & 27,1 & 62,1 & 50,4 & 59,2 & 56,7 & 4,8 & 4,3 \\
\hline 10 & 27,1 & 64,0 & 56,3 & 61,1 & 56,3 & 6,7 & 3,8 \\
\hline 11 & 29,1 & 66,0 & 48,5 & 57,2 & 52,4 & 6,7 & 8,7 \\
\hline 12 & 28,1 & 56,3 & 47,5 & 56,3 & 53,3 & 6,3 & 4,8 \\
\hline 13 & 30,0 & 65,0 & 55,3 & 60,1 & 56,3 & 9,7 & 6,7 \\
\hline 14 & 30,0 & 57,2 & 44,6 & 52,4 & 48,5 & 9,7 & 10,6 \\
\hline 15 & 28,1 & 64,0 & 54,3 & 61,1 & 55,3 & 8,7 & 6,7 \\
\hline 16 & 32,0 & 67,9 & 57,2 & 63,0 & 58,2 & 6,3 & 5,8 \\
\hline 17 & 30,0 & 66,0 & 55,8 & 66,0 & 60,1 & 3,8 & 2,9 \\
\hline 18 & 28,1 & 64,0 & 55,3 & 62,1 & 57,2 & 3,8 & 5,8 \\
\hline 19 & 32,0 & 62,1 & 55,3 & 61,1 & 55,3 & 5,8 & 3,8 \\
\hline 20 & 29,1 & 63,0 & 52,9 & 59,2 & 56,3 & 5,8 & 4,8 \\
\hline 21 & 30,0 & 67,9 & 60,1 & 64,0 & 59,2 & 5,8 & 5,8 \\
\hline 22 & 32,0 & 65,0 & 53,3 & 60,1 & 55,3 & 5,8 & 6,7 \\
\hline
\end{tabular}

\begin{tabular}{c|c|c|c|c|c|c|c|c}
\hline PACIENTE & 6R.Z & 6L.Z & AI-IA & IM-MI & A1R.Z & A1L.Z & SOBR. & AFAI \\
\hline 1 & 80,0 & 72,0 & 5,8 & 0,4 & 85,0 & 86,0 & 0,0 & 63,0 \\
\hline 2 & 75,0 & 78,0 & 8,7 & 0,0 & 93,5 & 93,0 & 2,9 & 57,2 \\
\hline 3 & 77,0 & 76,0 & 9,7 & 0,4 & 96,0 & 88,0 & 0,9 & 66,0 \\
\hline 4 & 70,0 & 79,0 & 8,7 & 0,0 & 93,0 & 89,0 & 0,0 & 66,0 \\
\hline 5 & 68,0 & 79,0 & 10,6 & 0,0 & 95,0 & 95,0 & 1,9 & 60,1 \\
\hline 6 & 70,0 & 83,0 & 13,5 & 0,0 & 105,0 & 93,0 & $-1,0$ & 73,7 \\
\hline 7 & 80,0 & 84,0 & 10,6 & 0,0 & 95,0 & 92,0 & 0,9 & 71,8 \\
\hline 8 & 62,0 & 72,0 & 7,7 & 0,9 & 94,0 & 84,0 & 1,9 & 59,2 \\
\hline 9 & 73,0 & 76,0 & 10,6 & 0,0 & 97,0 & 94,0 & 0,9 & 53,3 \\
\hline 10 & 77,0 & 81,0 & 9,7 & 0,0 & 95,0 & 91,0 & 2,9 & 66,0 \\
\hline 11 & 71,0 & 78,0 & 11,6 & 0,0 & 102,0 & 96,0 & $-1,0$ & 63,0 \\
\hline 12 & 70,0 & 82,0 & 7,7 & 0,0 & 94,5 & 94,0 & 0,9 & 62,1 \\
\hline 13 & 76,0 & 82,0 & 10,6 & 0,0 & 96,0 & 95,0 & $-1,0$ & 78,6 \\
\hline 14 & 76,0 & 78,0 & 6,7 & 0,0 & 93,0 & 83,0 & 0,0 & 76,6 \\
\hline 15 & 71,0 & 79,0 & 9,2 & 0,0 & 94,0 & 91,0 & $-3,9$ & 74,7 \\
\hline 16 & 78,0 & 84,0 & 9,7 & 1,4 & 91,0 & 92,0 & 2,9 & 55,3 \\
\hline 17 & 73,0 & 75,0 & 13,1 & 0,4 & 96,0 & 98,0 & 0,9 & 59,2 \\
\hline 18 & 73,0 & 81,0 & 9,7 & 0,0 & 88,0 & 98,0 & 1,9 & 63,0 \\
\hline 19 & 71,0 & 84,5 & 9,7 & 0,0 & 91,0 & 94,5 & 2,9 & 69,8 \\
\hline 20 & 70,0 & 81,0 & 9,7 & 0,9 & 95,0 & 88,0 & 0,9 & 71,8 \\
\hline 21 & 74,0 & 89,0 & 8,7 & 0,0 & 87,5 & 94,5 & 2,9 & 66,0 \\
\hline 22 & 69,5 & 78,5 & 8,7 & 0,0 & 90,0 & 91,0 & 2,9 & 66,9 \\
\hline
\end{tabular}


ANEXO J: Valores máximos e mínimos das medidas cefalométricas analisadas no Grupo I (Haas modificado), nas fases préexpansão (1), pós-expansão (2) e pós-contenção (3).

\begin{tabular}{|c|c|c|c|c|c|c|c|}
\hline \multicolumn{2}{|c|}{ FASE } & \multicolumn{2}{|c|}{$\begin{array}{c}\text { (1) } \\
\text { PRÉ-EXPANSÃO }\end{array}$} & \multicolumn{2}{|c|}{$\begin{array}{c}\text { (2) } \\
\text { PÓS-EXPANSÃO }\end{array}$} & \multicolumn{2}{|c|}{$\begin{array}{c}(3) \\
\text { PÓS-CONTENÇÃO }\end{array}$} \\
\hline $\begin{array}{l}\text { Tipo } \\
\text { Haas }\end{array}$ & $\begin{array}{l}\mathrm{N} \\
20\end{array}$ & $\begin{array}{c}\text { Valor } \\
\text { Máximo }\end{array}$ & $\begin{array}{c}\text { Valor } \\
\text { Mínimo }\end{array}$ & $\begin{array}{c}\text { Valor } \\
\text { Máximo }\end{array}$ & $\begin{array}{c}\text { Valor } \\
\text { Mínimo }\end{array}$ & $\begin{array}{c}\text { Valor } \\
\text { Máximo }\end{array}$ & $\begin{array}{c}\text { Valor } \\
\text { Mínimo }\end{array}$ \\
\hline \multicolumn{8}{|c|}{ Medidas } \\
\hline $\mathrm{NC}$ & & 33,0 & 25,0 & 34,0 & 27,0 & 36,0 & 27,0 \\
\hline $\mathrm{JL}$ & & 69,0 & 57,0 & 68,0 & 59,0 & 68,0 & 59,0 \\
\hline $\mathrm{R}$ & & 55,0 & 41,5 & 60,5 & 43,5 & 59,0 & 48,5 \\
\hline Cs & & 63,0 & 52,0 & 71,0 & 52,0 & 71,0 & 56,0 \\
\hline $\mathrm{Cl}$ & & 65,0 & 48,5 & 65,5 & 47,0 & 67,0 & 51,5 \\
\hline A6 & & 10,0 & 5,0 & 9,0 & 3,0 & 8,0 & 2,0 \\
\hline $6 \mathrm{~A}$ & & 10,0 & 4,0 & 9,0 & 3,5 & 8,0 & 3,0 \\
\hline $6 \mathrm{R}$ & & 86,0 & 72,0 & 87,0 & 64,0 & 84,0 & 61,0 \\
\hline $6 \mathrm{~L}$ & & 76,0 & 66,0 & 86,0 & 57,0 & 75,0 & 60,0 \\
\hline $\mathrm{AI}$ & & 10,0 & 5,0 & 14,0 & 6,0 & 14,0 & 6,0 \\
\hline IM & & 0,0 & 0,0 & 5,0 & 1,0 & 3,0 & 0,0 \\
\hline A11 & & 101,0 & 81,0 & 101,0 & 78,0 & 99,0 & 81,0 \\
\hline $\mathrm{A} 11$ & & 97,0 & 73,5 & 96,0 & 79,0 & 99,0 & 78,0 \\
\hline SOBI & EM. & 4,0 & $-1,0$ & 2,0 & $-3,0$ & 4,0 & $-2,0$ \\
\hline $\mathrm{AF}$ & & 76,0 & 55,0 & 79,0 & 59,0 & 77,0 & 57,0 \\
\hline
\end{tabular}


ANEXO K : Valores máximos e mínimos das medidas cefalométricas analisadas no Grupo II (Hyrax modificado), nas fases préexpansão (1), pós-expansão (2) e pós-contenção (3).

\begin{tabular}{|c|c|c|c|c|c|c|c|}
\hline \multicolumn{2}{|c|}{ FASE } & \multicolumn{2}{|c|}{$\begin{array}{c}\text { (1) } \\
\text { PRÉ-EXPANSÃO }\end{array}$} & \multicolumn{2}{|c|}{$\begin{array}{c}(2) \\
\text { PÓS-EXPANSÃO }\end{array}$} & \multicolumn{2}{|c|}{$\begin{array}{c}(3) \\
\text { PÓS-CONTENÇÃOO } \\
\end{array}$} \\
\hline $\begin{array}{c}\text { Tipo } \\
\text { Hyrax } \\
\end{array}$ & $\begin{array}{l}\mathrm{N} \\
21 \\
\end{array}$ & $\begin{array}{c}\text { Valor } \\
\text { Máximo } \\
\end{array}$ & $\begin{array}{c}\text { Valor } \\
\text { Mínimo } \\
\end{array}$ & $\begin{array}{c}\text { Valor } \\
\text { Máximo } \\
\end{array}$ & $\begin{array}{c}\text { Valor } \\
\text { Mínimo } \\
\end{array}$ & $\begin{array}{c}\text { Valor } \\
\text { Máximo } \\
\end{array}$ & $\begin{array}{c}\text { Valor } \\
\text { Mínimo } \\
\end{array}$ \\
\hline \multicolumn{8}{|c|}{ Medidas } \\
\hline NC- & & 34,0 & 24,0 & 36,0 & 26,0 & 36,0 & 28,0 \\
\hline JL- & & 67,0 & 56,0 & 69,0 & 59,0 & 69,0 & 59,0 \\
\hline RS & & 58,0 & 41,0 & 60,0 & 47,0 & 60,0 & 46,0 \\
\hline CS & & 61,0 & 50,5 & 69,0 & 56,0 & 69,0 & 55,5 \\
\hline CI & & 64,0 & 53,0 & 67,0 & 54,0 & 66,0 & 55,0 \\
\hline A6- & & 11,0 & 4,0 & 9,0 & 2,0 & 9,0 & 1,0 \\
\hline $6 \mathrm{~A}-$ & & 10,0 & 4,0 & 9,0 & 2,0 & 8,5 & 1,0 \\
\hline $6 \mathrm{R}$. & & 87,0 & 70,0 & 85,0 & 62,0 & 87,0 & 63,0 \\
\hline 6L. & & 79,0 & 62,0 & 60,0 & 78,0 & 72,0 & 59,0 \\
\hline AI-1 & & 9,0 & 3,0 & 14,0 & 4,5 & 15,0 & 7,0 \\
\hline IM- & & 0,0 & 0,0 & 7,0 & 0,0 & 2,0 & 0,0 \\
\hline $\mathrm{A} 1 \mathrm{R}$ & & 94,0 & 79,0 & 98,0 & 76,0 & 100,0 & 83,0 \\
\hline A1L & & 95,0 & 76,0 & 97,0 & 73,0 & 107,0 & 82,0 \\
\hline SOBR & M. & 5,0 & $-3,0$ & 3,0 & $-3,0$ & 3,0 & $-2,0$ \\
\hline $\mathrm{AF}$ & & 74,0 & 55,0 & 75,0 & 59,0 & 75,0 & 56,0 \\
\hline
\end{tabular}


ANEXO L : Valores máximos e mínimos das medidas cefalométricas analisadas no Grupo III (expansor colado) nas fases préexpansão (1), pós-expansão (2) e pós-contenção (3).

\begin{tabular}{|c|c|c|c|c|c|c|c|}
\hline \multicolumn{2}{|c|}{ FASE } & \multicolumn{2}{|c|}{$\begin{array}{c}\text { (1) } \\
\text { PRÉ-EXPANSÃO }\end{array}$} & \multicolumn{2}{|c|}{$\begin{array}{c}(2) \\
\text { PÓS-EXPANSÃO }\end{array}$} & \multicolumn{2}{|c|}{$\begin{array}{c}\text { (3) } \\
\text { PÓS-CONTENÇÃO }\end{array}$} \\
\hline $\begin{array}{c}\text { Tipo } \\
\text { Colado }\end{array}$ & $\begin{array}{l}\mathrm{N} \\
22 \\
\end{array}$ & $\begin{array}{c}\text { Valor } \\
\text { Máximo }\end{array}$ & $\begin{array}{c}\text { Valor } \\
\text { Mínimo }\end{array}$ & $\begin{array}{c}\text { Valor } \\
\text { Máximo }\end{array}$ & $\begin{array}{c}\text { Valor } \\
\text { Mínimo }\end{array}$ & $\begin{array}{c}\text { Valor } \\
\text { Máximo }\end{array}$ & $\begin{array}{c}\text { Valor } \\
\text { Mínimo }\end{array}$ \\
\hline \multicolumn{8}{|c|}{ Medidas } \\
\hline NC-C & & 30,0 & 20,3 & 33,0 & 24,2 & 32,0 & 24,2 \\
\hline JL-JI & & 66,0 & 54,3 & 67,9 & 56,3 & 67,9 & 56,3 \\
\hline RSR & & 53,3 & 38,8 & 58,2 & 42,7 & 60,1 & 44,6 \\
\hline $\mathrm{CSC}$ & & 58,7 & 45,6 & 66,0 & 51,4 & 66,0 & 52,4 \\
\hline $\mathrm{CIC}$ & & 61,1 & 48,5 & 60,1 & 49,5 & 61,1 & 48,5 \\
\hline A6-J & & 12,6 & 6,7 & 10,6 & 4,8 & 9,7 & 3,8 \\
\hline 6A-J & & 12,6 & 3,8 & 10,6 & 3,3 & 10,6 & 2,9 \\
\hline 6R.2 & & 89,0 & 73,0 & 86,0 & 58,0 & 80,0 & 62,0 \\
\hline $6 \mathrm{~L} .2$ & & 92,0 & 78,0 & 86,0 & 72,0 & 89,0 & 72,0 \\
\hline AI-I & & 8,7 & 2,9 & 15,5 & 6,7 & 13,5 & 5,8 \\
\hline IM-N & & 2,9 & 0,0 & 4,8 & 0,0 & 1,4 & 0,0 \\
\hline A1R. & & 94,0 & 78,0 & 99,0 & 85,0 & 105,0 & 85,0 \\
\hline A1L. & & 92,5 & 76,0 & 98,0 & 78,0 & 98,0 & 83,0 \\
\hline SOBRE & & 4,8 & $-3,9$ & - & - & 2,9 & $-3,9$ \\
\hline $\mathrm{AFA}$ & & 76,6 & 49,5 & - & - & 78,6 & 53,3 \\
\hline
\end{tabular}




\section{REFERENNCIAS}

\section{BIBLIOGRÁFICAS}




\section{REFER ÂNCIAS BIBLIOGRÁFICAS *}

1. ADKINS, M.D.; NANDA, R.S., CURRIER, G.F. Arch perimeter changes on rapid maxillary expansion. Am. J. Orthod. Dentofacial Orthop., v.97, n.3, p.194-9, Mar., 1990.

2. AKKAYA, S.; LORENZON, S.; UÇEM, T.T. Comparison of dental arch and arch perimeter changes between bonded rapid and slow maxillary expansion procedures. Europ. J. Orthod., v.20, n.3, p.255-61, June, 1998.

3. AKKAYA, S.; LORENZON, S, UÇEM, T.T. A comparison of sagital and vertical effects between bonded rapid and slow maxillary expansion procedures. Eur. J. Orthod., v.21, n.2, p.175-80, 1999.

4. ALMEIDA, G.A.; CAPELOZZA FILHO, L.; TRINDADE JÚNIOR, A.S. Expansão rápida da maxila : um estudo prospectivo. Ortodontia, v.32, n.1, p.45-56, jan./abr.,1999.

* Normas recomendadas para uso no âmbito da Universidade de São Paulo, com base no documento "Orientações básicas para apresentação de dissertações e teses na FOB-USP", publicado pelo serviço de Biblioteca e Documentação da Faculdade de Odontologia de Bauru - Universidade de São Paulo, 1991. 
5. ALPERN, M.C.; YUROSKO, J.J. Rapid palatal expansion in adults with and without surgery. Angle Orthod., v.57, n.3, p.254-63, July, 1987.

6. ALPINER. M.L.; BEAVER, H.A. Criteria for rapid maxillary expansion. J. Mich. Dent. Ass., v.53, n.1, p.39-42, Sept., 1971.

7. ANDREWS, L.F. The six keys to normal occlusion. Am. J. Orthod., v.62, n.3, p.296-309, Feb., 1971.

8. ANGELL, E. H. Treatment of irregularity of the permanent or adult teeth. Dent. Cosmos, v.1, p.540-4, 599-601,1860.

9. ASANZA, S.; CISNEROS, G. J.; NIEBERG, L.G. Comparison of Hyrax and bonded expansion appliances. Angle Orthod., v.67, n.1, p.15-22, Feb., 1997.

10.BARBER, A.F.; SIMS, M.R. Rapid maxillary expansion and external root resorption in man: a scanning electron microscope study. Am. J. Orthod., v.79, n.6, p.630-52, June, 1981.

11.BARBOSA, J.A. Estudo cefalométrico longitudinal do crescimento anterior da face, relacionado com a sobremordida, em adolescentes, brasileiros, leucodermas, com oclusão normal. Bauru, 1978. 63p. Dissertação (Mestrado) - Faculdade de Odontologia Bauru, Universidade de São Paulo. 
12. BARNES, R. E. The early expansion of deciduous arches and its effect on the developing permanent dentition. Am. J. Orthod., v.42, n.2, p.83-92, Feb., 1956.

13.BERLOCHER, W.C.; MÜELLER, B.H.; TINANOFF, N. The effect of maxillary palatal expansion on the primary dental arch circumference. Pediat. Dent., v.2, n.1, p.27-30, 1980.

14.BETTS, N.J. et al. Diagnosis and treatment of transverse maxillary deficiency. Int. J. Adult Orthod. Orthog. Surg., v.10, n.2, p.75-96, 1995.

15. BIEDERMAN, W. A hygienic appliance for rapid expansion. J. Pract. Orthod., v.2, n.2, p.67-70, Feb., 1968.

16. BIEDERMAN, W.; CHEN, B. Rapid correction of Class III malocclusion by midpalatal expansion. Am. J. Orthod., v.63, n.1, p.47-55, Jan., 1973.

17.BISHARA, S.E.; STALEY, R.N. Maxillary expansion : clinical implications. Am. J. Orthod. Dentofacial Orthop., v.91, n.1, p.3-14, Jan., 1987.

18.BJÖRK, A. Facial growth in man, studied with the aid of metallic implants. Acta Odont. Scand., v.13, p.9-34, 1955.

19.BROGAN, W.F. The stability of maxillary expansion. Aust. Dent. J., v.22, n.2, p.92-9, April, 1977. 
20.BRUDVIK, J.S.; NELSON, D.R. Adult palatal expansion prostheses. J. Prosth. Dent., v.45, n.3, p.315-20, Mar., 1981.

21.BYRUN JÚNIOR, A.G. Evaluation of anterior-posterior and vertical skeletal changes vs. Dental change in rapid palatal expansion cases as studied by lateral cephalograms. Am. J. Orthod., v.60, n.4, p.419, Oct., 1971. /Abstract/.

22. CAPELOZZA FILHO, L.; SILVA FILHO, O.G. Expansão rápida da maxila: considerações gerais e aplicação clínica. Parte I. Rev. Dental Press Ortod. Ortop. Max., v.2, n.3, p.88-102, maio/jun.,1997.

23.CAPELOZZA FILHO, L.; SILVA FILHO, O.G. Expansão rápida da maxila: considerações gerais e aplicação clínica. Parte II. Rev. Dental Press Ortod. Ortop. Max., v.2, n.4, p.86-108, jul./ago., 1997.

24.CARREIRA, D.G.G. Avaliação cefalométrica longitudinal das alterações dentoesqueléticas produzidas pela expansão rápida da maxila. Bauru, 1999. 194p. Dissertação (Mestrado) - Faculdade de Odontologia de Bauru, Universidade de São Paulo.

25.CAVASSAN,A.O. et al. Expansão rápida da maxila : avaliação em modelos de gesso. Ortodontia, v.26, n.3, p.53-63, set./dez., 1993.

26.CHACONAS, S.J.; CAPUTO, A.A. Observation of orthopedic force distribution produced by maxillary orthodontic appliances. Am. J. Orthod., v.82, n.6, p.492-501, Dec., 1982. 
27.CHANG, J.Y.; MCNAMARA JÚNIOR, J.A.; HERBERGER, T.A. A longitudinal study of skeletal side effects induced by rapid maxillary expansion. Am. J. Orthod. Dentofacial Orthop., v.112, n.3, p.330-7, Sept.,1997.

28. CLEALL, J. F; et al. Expansion of the midpalatal suture in the monkey. Angle Orthod., v.35, n.1, p.23-35, Jan., 1965.

29. COHEN, M.; SILVERMAN E. A new and simple palate splitting device. J. Clin. Orthod., v.7, n.6, p.368-9, June, 1973.

30. DAHLBERG, G. Statistical methods for medical and biological students. New York, Intescence, 1940 apud HOUSTON ${ }^{52}$,W.B. p. 224.

31.DARENDELILER, M.A.; LORENZON, C. Maxillary expander using light, continuous force and autoblocking. J. Clin. Orthod., v.30, n.4, p.212-6, Apr.,1996.

32.DAVIS, W.M.; KRONMAN, J. Anatomical changes induced by splitting of the midpalatal suture. Angle Orthod., v.39, n.2, p.126-32, April, 1969.

33. DERICHSWELLER, H. La disjontction de la suture palatine mediane. In: Congress of the European Orthodontics Society Transations. Europ. Orthodont. Soc. Trans., p.257-265, 1953.

34. DIPAOLO, R.J. Thoughts on palatal expansion. J. Clin. Orthod., v.4, n.9, p.493-7, Sept., 1970. 
35.FALTIN JÚNIOR, K.; MOSCATIELLO V.A.M.; BARROS, E.C. Disjuntor palatino Faltin Jr. Alterações dentofaciais decorrentes da disjunção da sutura palatina mediana. Rev. Dental Press Ortod. Ortop. Fac., v.4, n.4, p.5-13, jul./ago., 1999.

36. FRANKLIN, J.B. Certain factors of aberration to be considered in clinical roentgenographic cephalometry. Am. J. Orthod., v.38, n.5, p.351-68, May, 1952.

37.GARDNER, G.E.; KRONMAN, J.H. Cranioskeletal displacements caused by rapid palatal expansion in the Rhesus monkey. Am. J. Orthod., v.59, n.2, p.146-55, Feb., 1971.

38.GOLDREICH, H.N. et al. Considerações sobre os erros em cefalometria. Rev. Dental Press Ortod. Ortop. Max., v.3, n.1, p.81-90, jan./fev., 1998.

39.GRUMONS, D.C.; COPPELLO, M.A.K. A frontal asymmetry analysis. J. Clin. Orthod., v.21, n.7, p.448-65, July, 1987.

40. GRYSON, J.A. Changes in mandibular interdental distance concurrent with rapid maxillary expansion. Angle Orthod., v.47, n.3, p.186-92, July, 1977.

41.GUGINO, C.F. An Orthodontic philosophy. $11^{\mathrm{a}}$ Ed., Denver, Colorado, RM/Communicator, division of Rocky Mountain Associates International Inc., 1977. 
42. HAAS, A.J. Rapid expansion of the maxillary dental arch and nasal cavity by opening the midpalatal suture. Angle Orthod., v.31, n.2, p.73-90, April 1961.

43. HAAS, A.J. The treatment of maxillary deficiency by opening the midpalatal suture. Angle Orthod., v.35, n.3, p.200-17, July, 1965.

44. HAAS, A.J. Palatal expansion : just the beginning of dentofacial orthopedics. Am. J. Orthod., v.57, n.3, p.219-55, March, 1970.

45.HAAS, A.J. Interviews. J. Clin. Orthod., v.7, n.4, p.227-45, April 1973.

46. HAAS, A.J. Long-term posttreatment evaluation of rapid palatal expansion. Angle Orthod., v.50, n.3, p.189-217, July, 1980.

47.HALPERN, M.R. A study of the maxillary changes during rapid palatal expansion. Am. J. Orthod., v.51, n.1, p.90-1, Jan., 1970. /Abstract/.

48.HARTGERINK, D.V.; VIG, P.S.; ABBOT, D.W. The effect of rapid maxillary expansion on nasal airway resistance. Am. J. Orthod. Dentofacial Orthop., v.92, n.5, p.381-9, Nov., 1987.

49. HEFLIN, B.M. A three-dimensional cephalometrics study of the influence of expansion of the midpalatal suture on the bones of the face. Am. J. Orthod., v.57, n.2, p.194-5, Feb., 1970. /Abstract/. 
50.HERSHEY, H.G.; STEWART, B.L.; WARREN, D.W. Changes in nasal airway resistance associated with rapid maxillary expansion. Amer. J. Orthod., v.69, n.3, p.274-84, March, 1976.

51.HOFFER, F.L.; WALTERS, R.D. Adaptive changes in the face of the Macaca Mulatta monkey following orthopedic opening of the midpalatal suture. Angle Orthod., v.45, n.4, p.282-90, Oct., 1975.

52.HOUSTON, W.J.B. Analysis of errors in orthodontic measurements. Am. J. Orthod., v.83, n.5, p.382-90, May, 1983.

53.HOWE, R. P. Palatal expansion using a bonded appliance. Report of a case. Am. J. Orthod., v.82, n.6, p.464-468, Dec., 1982.

54.JANSON, G.R.P. Estudo tridimensional das assimetrias dentárias e esqueléticas na má oclusão de Classe II, subdivisão. Bauru, 1998. 271p. Tese (Livre Docência) - Faculdade de Odontologia de Bauru, Universidade de São Paulo.

55.KAWAKAMI, R.Y. Comparação dos efeitos dentoesqueléticos, produzidos por dois tipos de disjuntores palatinos, por meio de análise cefalométrica em norma lateral. Bauru, 1995. 155p. Dissertação (Mestrado) - Faculdade de Odontologia de Bauru, Universidade de São Paulo.

56. KORKHAUS, G. Present orthodontic thought in Germany. Jaw widening with active appliances in cases of mouth breathing. Am. J. Orthod., v.46, n.3, p.187-206, March, 1960. 
57. KREBS, A. Expansion of the midpalatal suture, studied by means of metallic implants. Acta Odont. Scand., v.17, n.4, p.491-501, Dec., 1959.

58. KREBS, A. Midpalatal suture expansion studied by the implant method over a seven-year period. Europ. Orthod. Soc., v.40, p.131-42, July, 1964.

59.LÉON, A. P. F. et al. Aparelho expansor colado com cobertura acrílica para o controle vertical, durante a expansão rápida da maxila: apresentação de um caso clínico. . Rev. Dental Press Ortod. Ortop. Max., v.3, n.3, p.2533, maio/jun.1998.

60.LETZER, G.M.; KRONMAN, J.H. A posteroanterior cephalometric evaluation of craniofacial asymmetry. Angle Orthod., v.37, n.7, p.20511, July,1963.

61.LINDER-ARONSON, S.; LINDGREN, J. The skeletal and dental changes effects of rapid maxillary expansion. Brit. J. Orthod., v.6, n.1, p.25-9, Jan., 1979.

62. MAJOURAU, A.; NANDA, R. Biomechanical basis of vertical dimension control during rapid palatal expansion therapy. Am. J. Orthod. Dentofacial Orthop., v.106, n.3, p.322-8, Sept., 1994.

63.MARTINS, D.R.; ALMEIDA, R.R.; DAINESI, E.A. Mordidas cruzadas anterior e posterior. Parte I - diagnóstico e tratamento precoces. Apresentação de casos clínicos. Odonto Master, v.1 n.2, p.1-19, 1994. 
64.MARTINS, D.R.; HENRIQUES, J.F.C.; VELÁSQUEZ, N.Z. Aparelho tipo Hyrax colado : uma outra alternativa para o tratamento da mordida cruzada posterior. Rev. Dental Press Ortod. Ortop. Fac., v.3, n.5, p.4144, set./out., 1998.

65. MAZZIEIRO, E. T. Estudo cefalométrico, em norma frontal, das alterações dentoesqueléticas após a expansão rápida da maxila, em pacientes na faixa etária de 10 a 16 anos e 2 meses. Bauru, 1994. 128p. Dissertação (Mestrado) - Faculdade de Odontologia de Bauru, Universidade de São Paulo.

66. MCNAMARA JUNIOR, J. A.; BRUDON, W.L. Bonded rapid maxillary expansion appliances. In: Orthodontic and orthopedic treatment in the mixed dentition. 2 ed. Ann Arbor, Needham Press, 1993. Cap.8, p.145-169.

67.MEMIKOGLU, T.U.; ISERI, H. Nonextraction treatment with a rigid acrylic, bonded rapid maxillary expander. J. Clin. Orthod., v.31, n.2, p.113-8, Feb., 1997.

68. MEMIKOGLU, T.U.; ISERI, H. Effects of a bonded rapid maxillary expansion appliance during orthodontic treatment. Angle Orthod., v.69, n.3, p.251-6, June, 1999.

69. MEMIKOGLU, T.U.; ISERI, H.; UYSAL, M.E. Three dimensional dentofacial changes with bonded and banded rapid maxillary expansion appliances. Europ. J. Orthod., v.16, p.342, 1994./Abstract/. 
70.MONDRO, J.F.; LITT, R.A. An improved direct-bonded palatal expansion appliance. J. Clin. Orthod., v.11, n.3, p.203-6, March, 1977.

71.MOSS, J.P. Rapid expansion of the maxillary arch. Part I. J. Pract. Orthod., v.2, n.4, p.165-71, April, 1968.

72. MOSS, J.P. Rapid expansion of the maxillary arch. Part II. J. Pract. Orthod., v.2, n.5, p.215-23, May, 1968.

73.MOSSAZ, K.; MOSSAZ, J.F.; MOSSAZ, C. F. Slow maxillary expansion: a comparison between banded and bonded appliances. Eur. J. Orthod., v.11, n.1, p.67-76, Feb., 1989.

74.MOUSSA, R.; O'REILLY, M.T.; CLOSE, J.M. Long-term stability of rapid palatal expander treatment and edgewise mechanotherapy. Am. J. Orthod. Dentofacial Orthop., v.108, n.5, p.478-88, Nov.,1995.

75. MULICK, J.F. Clinical use of the frontal headfilm. Angle Orthod., v.35, n.4, p.299-304, Oct.,1965.

76. MURRAY, J.M.G.; CLEALL, J.F. Early tissue response of rapid maxillary expansion in the midpalatal suture of the Rhesus monkey. J. Dent. Res., v.50, n.6, p.1654-60, Dec./Nov., 1971.

77.PEARSON, L.E. Treatment of a severe openbite excessive vertical pattern with an eclectic non-surgical approach. Angle Orthod., v.61, n.1, p.71-6, 1991. 
78. PEARSON, L.E.; PEARSON, B.L. Rapid maxillary expansion with incisor intrusion : a study of vertical control. Am. J. Orthod. Dentofacial Orthop., v.115, n.5, p.576-82, May,1999.

79.REED, N.; GHOSH, J.; NANDA, R.S. Comparison of treatment outcomes with banded and bonded rapid palatal expansion appliances. Am. J. Orthod. Dentofacial Orthop., v.116, n.1, p.31-40, July,1999.

80. RICKETTS, R.M. Perspectives in the clinical application of cephalometrics. Angle Orthod., v.51, n.2, p.115-50, April, 1981.

81.SANDSTROM, R.A.; KLAPPER, L.; PAPACONSTANTINOU, S. Expansion of the lower arch concurrent with rapid maxillary expansion. Am. J. Orthod. Dentofacial Orthop., v.94, n.4, p.296-302, Oct., 1988.

82. SANTOS PINTO, C.C.M.; HENRIQUES, J.F.C. Expansão rápida da maxila: preceitos clínicos e radiográficos. Rev. Odont. USP, v.4, n.2, p.164-6, abr./jun., 1990.

83.SARVER, D. M.; JOHNSTON, M. K. Skeletal changes in vertical and anterior displacement of the maxilla with bonded rapid palatal expansion appliance. Amer. J. Orthod. Dentofacial Orthop., v.95, n.6, p.462-6, June 1989.

84.SATHER,A.H. Oral roentgenology. Oral Surg., v.16, n.2, p.154-8, Feb.,1963. 
85. SATO, K. Estudo cefalométrico radiográfico de padrões craniofaciais, em norma lateral e frontal, em adolescentes brasileiros, leucodermas, com oclusão dentária normal. São Paulo, 1992. 100p. Dissertação (Mestrado) - Faculdade de Odontologia, Universidade de São Paulo.

86.SATO, K.; VIGORITO, J.W.; CARVALHO, L.S. Avaliação cefalométrica da disjunção rápida da sutura palatina mediana, através da telerradiografia em norma frontal (PA). Rev. Odont. Metod., v.6, n.1, p.123-136, 1985.

87. SCAVONE JÚNIOR, E. O perfil facial tegumentar dos 13 aos 18 anos de idade. Bauru, 1996. 219p. Dissertação (Doutorado) - Faculdade de Odontologia Bauru, Universidade de São Paulo.

88. SCHNEIDMAN, E.; WILSON, S.; ERKIS, R. Two point rapid palatal expansion : an alternative approach to traditional treatment. Pediat. Dent., v.12, n.2, p.92-7, Apr./May, 1990.

89. SILVA, C.C.A. Avaliação cefalométrica dos efeitos do aparelho guia de erupção no tratamento da má oclusão de Classe II, divisão 1, após 2 anos. Bauru, 1997. 175p. Dissertação (Mestrado) - Faculdade de Odontologia Bauru, Universidade de São Paulo.

90. SILVA FILHO, O.G.; CAPELOZZA FILHO,L. Expansão rápida da maxila: preceitos clínicos. Ortodontia, v.21, n.1, p.61-81, jan./jun., 1988. 
91.SILVA FILHO, O.G.; FREITAS, S. F.; CAVASSAN, A.O. Oclusão: escolares de Bauru. Prevalência de oclusão normal e má-oclusão na dentadura mista em escolares de Bauru (São Paulo). Rev. Assoc. Paulista Cirurg. Dent., v.43, n. 6, p.287-90, nov./dez. 1989.

92.SILVA FILHO, O.G.; FREITAS, S. F.; CAVASSAN, A.O. Prevalência de oclusão normal e má-oclusão em escolares na Cidade de Bauru (São Paulo). Parte I: Relação sagital. Rev. Odont. USP., v.4, n.2, p.130-7, abr./jun., 1990.

93.SILVA FILHO, O.G.; FREITAS, S. F.; CAVASSAN, A.O. Prevalência de oclusão normal e má-oclusão em escolares na Cidade de Bauru (São Paulo). Parte II: influência da estratificação sócio-econômica Rev. Odont. USP., v.4, n.3, p.185-96, jul./set., 1990

94.SILVA FILHO, O.G., MONTES, L.A.P.; TORELLY, L.F. Rapid maxillary expansion in the deciduous and mixed dentitions evaluated through posteroanterior cephalometric analysis. Am. J. Orthod. Dentofacial Orthop., v.107, n.3, p.268-75, Mar.,1995.

95.SILVA FILHO, O.G; PINHEIRO JÚNIOR, J.M.P.; CAVASSAN, A.O. Comportamento dos incisivos centrais superiores após a expansao rápida da maxila na dentadura mista : um estudo piloto longitudinal radiográfico. Rev. Dental Press Ortod. Ortop. Max., v.2, n.1, p.68-85, jan./fev., 1997. 
96.SILVA FILHO, O.G.; VALLADARES NETO, J.; ALMEIDA, R.R. Early correction of posterior crossbite : biomechanical characteristics of the appliances. J. Pedod., v.13, n.3, p.195-221, Spring 1989.

97.SILVA FILHO, O.G., VIllAS BOAS, M.C.; CAPELOZZA FILHO, L. Rapid maxillary expansion in the primary and mixed dentitions : a cephalometric evaluation. Am. J. Orthod. Dentofacial Orthop., v.100, n.2, p.171-9, Aug., 1991.

98.SILVA FILHO, O.G. et al. Expansão rápida da maxila : reaproveitamento imediato da ação expansora do parafuso. Ortodontia, v.27 n.1, p.31-37, jan./abr., 1994.

99.SILVA FILHO, O.G. et al. Expansão rápida da maxila na dentadura permanente : uma avaliação cefalométrica. Ortodontia, v.27 n.2, p.6876, maio/ago., 1994.

100. SMITH, S.W.; ENGLISH, J.D. Orthodontic correction of a Class III malocclusion in an adolescent patient with a bonded rapid palatal expansion and protraction face mask. Am. J. Orthod. Dentofacial Orthop., v.116, n.2, p.177, 1999.

101. SPILLANE, L.M.; MCNAMARA JÚNIOR, J.A. Maxillary adaptation to expansion in the mixed dentition. Seminars in Orthod., v.1, n.3, p.176-87, Sep., 1995. 
102. SPOLYAR, J. L. The design, fabrication, and use of a full-coverage bonded rapid maxillary expansion appliance. Am. J. Orthod. Dentofacial Orthop., v.86, n.2, p.136-145, Aug. 1984.

103. STARNBACH, H. K; CLEALL, J. F. The effects of splitting the midpalatal suture on the surrounding structures. Am. J. Orthod., v.50, n.12, p.923-4, Dec., 1964. /Abstract/ .

104. STARNBACH, H. K. et al. Facioskeletal and dental changes resulting from rapid maxillary expansion. Angle Orthod., v.36, n.2, p.152-164, Apr., 1966.

105. STEIMAN, H. Visual aid for bonded acrylic rapid maxillary palatal expanders. J. Clin. Orthod., v.31, n.5,p.327, May, 1997.

106. TIMMS, D.J. The dawn of rapid maxillary expansion. Angle Orthod., v.69, n.3, p.247-50, June, 1999.

107. VARDIMON. A.D. et al. Rapid palatal expansion : Part 1. Mineralization pattern of the midpalatal suture in cats. Am. J. Orthod. Dentofacial Orthop., v.113, n.4, p.371-8, Apr., 1998.

108. VELÁZQUEZ, P.; BENITO, E.; BRAVO, L.A. Rapid maxillary expansion. A study of the long-term effects. Am. J. Orthod. Dentofacial Orthop., v.109, n.4, p.361-7, Apr.,1996.

109. VIAZIS, A.D. et al. Designs and applications of palatal expansion appliances. J. Clin. Orthod., v.26, n.4, p.239-43, Apr., 1992. 
110. VIGORITO, J.W. Estudo comparativo de algumas características mandibulares em maloclusões de Classe I e de Classe II, divisão 1, de Angle. São Paulo, 1972. 78p. Tese (Doutorado) - Faculdade de Odontologia, Universidade de São Paulo.

111. WERTZ, R. A. Skeletal and dental changes accompanying rapid midpalatal suture opening. Am. J. Orthod., v.58, n.1, p.41-66, July, 1970.

112. WERTZ, R.; DRESKIN, M. Midpalatal suture opening: a normative study. Am. J. Orthod., v.71, n.4, p.367-81, April, 1977.

113. WHITE, R.E. A cephalometric appraisal of changes in the maxillofacial complex resulting from palatal suture expansion utilizing fixed appliance therapy. Am. J. Orthod., v.61, n.5, p.527-8, May, 1972.

114. ZIMRING, J.F.; ISAACSON, R.J. Forces produced by rapid maxillary expansion. III. Forces present during retention. Angle Orthod., v.35, n.3, p.178-86, July, 1965. 
ABSTRACT 


\section{ABSTRACT}

This cephalometric comparative study analyzed the effects of three types of rapid maxillary expansion $(R M E)$ appliances, with the objective of observing, by means of frontal cephalograms, the dentoskeletal alterations resulted from the expansion and the possible differences among the used appliances. The sample consisted of 63 patients ( 23 male and 40 female) divided into three groups: Group I, composed by 20 patients that used the modified Haas expander, being 12 female and 8 male, aged 13 years and 5 months in average by the time the appliance was applied; - Group II, composed by 21 patient that used the modified Hyrax type appliance, 14 female and 7 male, aged 12 years and 10 months in average by the time the appliance was applied, and - Group III, composed by 22 patients that used the bonded rapid palatal expansion appliance, 14 female and 8 male, aged 12 years and 5 months in average by the time the appliance was applied. All patients were $\mathrm{x}$-rayed in the pre-expansion phase, immediately after the expansion, and after three months of active retention with the appliance, totalizing 189 posteroanterior radiographs for the accomplishment of this study. Based on the employed methodology and in the obtained results, it was verified that: - the three appliance types demonstrated similar orthopedic results, like the increase of the inferior portion of the nasal cavity and of the maxillary width, which were kept stable during retention period; - the maxillary molars (anchorage teeth) showed similar behavior; - the mandibular intermolars distances increased in the three groups, but with significant differences among Group III, that presented few alterations, and the other groups; - the central maxillary incisors presented similar behavior in the three groups, during the expansion and retention periods, characterized by the inclination movements and by the root divergence and convergence of the crowns; - analyzing the overbite 
and the lower anterior facial height variables, it was concluded that the three appliance types showed similar vertical alterations, due to $R M E$. 